\title{
DuEPublico
}

- Duisburg-Essen Publications online

\section{Fiasko - Scheitern in der Frühen Neuzeit}

Herausgeber: Brakensiek, Stefan; Claridge, Claudia

Dieser Text wird über DuEPublico, dem Dokumenten- und Publikationsserver der Universität Duisburg-Essen, zur Verfügung gestellt.

Die hier veröffentlichte Version der E-Publikation kann von einer eventuell ebenfalls veröffentlichten Verlagsversion abweichen.

DOI: https://doi.org/10.14361/9783839427828

URN: urn:nbn:de:hbz:464-20180823-110425-9

Link: https://duepublico.uni-duisburg-essen.de:443/servlets/DocumentServlet?id=46498

Lizenz:

(c) (7) Dieses Werk kann unter einer Creative Commons Namensnennung 4.0

Quelle: Erschienen im transcript Verlag, 2015.

Print-ISBN 978-3-8376-2782-4 - PDF-ISBN 978-3-8394-2782-8

Die frei zugängliche digitale Publikation wurde ermöglicht mit Mitteln des BMBF-Projektes OGeSoMo der Universitätsbibliothek Duisburg-Essen. 


\section{Stefan Brakensiek, Claudia Claridge (Hg.)}

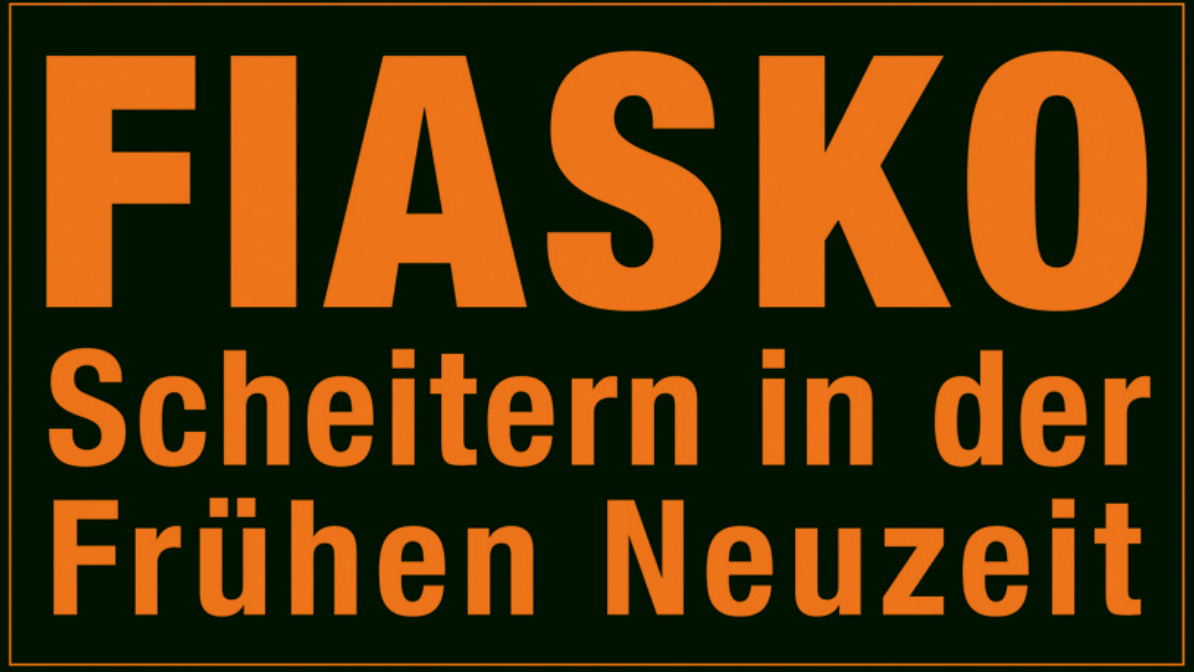

Beiträge zur Kulturgeschichte des Misserfolgs

[transcript] Histoire 
Stefan Brakensiek, Claudia Claridge (Hg.)

Fiasko - Scheitern in der Frühen Neuzeit

Histoire | Band 64 

Stefan Brakensiek, Claudia Claridge (Hg.)

\section{Fiasko - Scheitern in der Frühen Neuzeit}

Beiträge zur Kulturgeschichte des Misserfolgs

[transcript $]$ 
Gefördert mit Mitteln der Fakultät für

Geisteswissenschaften der Universität Duisburg-Essen.

Erschienen im transcript Verlag 20I5

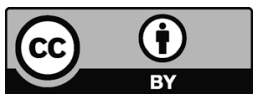

Dieses Werk ist lizenziert unter der Creative Commons Attribution 4.0 (BY). Diese Lizenz erlaubt unter Voraussetzung der Namensnennung des Urhebers die Bearbeitung, Vervielfältigung und Verbreitung des Materials in jedem Format oder Medium für beliebige Zwecke, auch kommerziell.

(Lizenztext: https://creativecommons.org/licenses/by/4.o/deed.de)

Die Bedingungen der Creative Commons Lizenz gelten nur für Originalmaterial. Die Wiederverwendung von Material aus anderen Quellen (gekennzeichnet mit Quellenangabe) wie z.B. Schaubilder, Abbildungen, Fotos und Textauszüge erfordert ggf. weitere Nutzungsgenehmigungen durch den jeweiligen Rechteinhaber.

\section{Bibliografische Information der Deutschen Nationalbibliothek}

Die Deutsche Nationalbibliothek verzeichnet diese Publikation in der Deutschen Nationalbibliografie; detaillierte bibliografische Daten sind im Internet über http://dnb.d-nb.de abrufbar.

\section{(C) Stefan Brakensiek, Claudia Claridge (Hg.)}

Umschlagkonzept: Kordula Röckenhaus, Bielefeld

Satz: Justine Haida, Bielefeld

Printed in Germany

Print-ISBN 978-3-8376-2782-4

PDF-ISBN 978-3-8394-2782-8

Gedruckt auf alterungsbeständigem Papier mit chlorfrei gebleichtem Zellstoff. Besuchen Sie uns im Internet: http://www.transcript-verlag.de

Bitte fordern Sie unser Gesamtverzeichnis und andere Broschüren an unter: info@transcript-verlag.de 


\section{Inhalt}

\section{Editorial}

Fiasko - Scheitern in der Frühen Neuzeit

Stefan Brakensiek/Claudia Claridge | 7

"A full Account of the rise, progress and declension of our Journal" Negotiations of failure in early English newspapers

Birte Bös | 11

\section{Projektemacher}

Zum Hintergrund ökonomischen Scheiterns in der Frühen Neuzeit

Stefan Brakensiek | 39

\section{The Darién Scheme}

Failure and its treatment in the press

Claudia Claridge 59

\section{Fragments as Failed Texts}

Conceptual Problems in Thomas More's History of King Richard III and Percy Bysshe Shelley's A Philosophical View of Reform

Jens Martin Gurr| 85

\section{A Miserable Sight}

The Great Fire of London (1666)

Christoph Heyl | 111

\section{Warum Religionsgespräche scheitern}

Anmerkungen zum innerchristlichen Diskurs des 16. Jahrhunderts Marcel Nieden | 135 


\section{Substituting Fantasy for Achievement}

Walter Ralegh's Failure as Discoverer and its Vindication

Frank Erik Pointner | 171

\section{Glücksschmied und Schiffbruch}

Reflexionen des Scheiterns zwischen Heinrich v. Kleist, Johann Gottfried Herder, Eberhard Werner Happel und Adam Olearius

Jörg Wesche | 197 


\section{Editorial}

\section{Fiasko - Scheitern in der Frühen Neuzeit}

Scheitern kann nur, wer Pläne hat. Die Beschäftigung mit dem Thema ist also zugleich eine Beschäftigung mit der Frage, wie sich Menschen ihre Zukunft vorstellen, welche Absichten sie hegen, und wie sie damit umgehen, wenn sie mit diesen Plänen keinen Erfolg haben. Die Erfolglosigkeit muss zugleich eklatant, für das soziale Umfeld des Scheiternden offensichtlich sein, sonst wird man eher von Rückschlägen, Misserfolgen, verzeihlichen Fehlern sprechen. Der Scheiternde ist deshalb von seinem Scheitern als Person betroffen - moralische Urteile Dritter über ihn sind die Regel. Das sagt freilich noch nichts darüber, wie der Scheiternde mit seinem Versagen umgeht: Scham - Leugnen - Lernen? Reinhard Koselleck hat darauf hingewiesen, dass viele neue Ideen ihr Entstehen einem Scheitern verdanken. Die Verlierer seien prädestiniert dazu, über den Zustand der Welt und das eigene Handeln nachzudenken. Scheitern ist demnach günstigenfalls die Bedingung der Möglichkeit, aus Schaden klug zu werden. Reflexivität aus der Erfahrung des Scheiterns also? Für ein historisches Nachdenken eignet sich das Thema jedenfalls gut.

Dass der Umgang mit dem Scheitern keine individuelle Angelegenheit ist, sondern im Rahmen von kulturellen codes funktioniert, erweisen die aktuellen Diskussionen über start-up-Unternehmen. Während ein Firmengründer in den USA mehrfach Fehlschläge erleiden kann und ihm dies sogar als wertvolle Erfahrung für das nächste Projekt zugerechnet wird, gilt ein erfolgloser Unternehmer auf dem europäischen Kontinent als gescheitert. Er braucht mitunter Jahre, um wirtschaftlich wieder auf die Beine zu kommen. Vergleichbare Verhaltensweisen und Erfahrungen werden in der einen Kultur als Risikofreude und als Lernprozess positiv gedeutet, die Verarbeitung eines Scheiterns erscheint hier recht unproble- 
matisch. In der anderen Kultur gibt ein geschäftlicher Misserfolg Anlass, über die mangelnden Fähigkeiten des Gescheiterten zu sprechen, es stellt sich hier die drängende Frage nach Verantwortung, ja Schuld. Wenn zwei Kulturen heutzutage zeitgleich solch unterschiedliche Wege gehen, stellt sich die Frage, wie sich der Umgang mit dem Scheitern zu anderen Zeiten darstellte.

Die europäische Frühneuzeit erschien den Autoren dieses Bandes ${ }^{1}$ dafür besonders geeignet, da in dieser Epoche im Falle eines Scheiterns regelmäßig heftige Auseinandersetzungen entbrannten über die Frage, ob allein die beteiligten Personen dafür verantwortlich sind, oder ob das Misslingen auf die blinde Macht des Schicksals verweist oder auf das unmittelbare Eingreifen Gottes.

Nimmt man die frühneuzeitliche Wortgeschichte im Deutschen und im Englischen in den Blick, bietet sich gegenüber der aktuellen Diskussion um unternehmerisches Scheitern ein anderes Bild: Das neuhochdeutsche Wort Scheitern hat in seiner bildhaften Herkunft einen materiellen Hintergrund, denn es bezeichnet ursprünglich das Auseinanderbrechen eines Schiffes, das dabei zu Holzscheiten zerschellt. Dem Scheitern eines Schiffes liegen zwar meist höhere Gewalten zugrunde, Naturgewalten zumal, vielleicht auch göttliches Walten. Es kann freilich auch auf Navigationsfehler zurückzuführen sein. Der Wortursprung umfasst im Deutschen demnach sowohl schuldloses als auch schuldhaftes Scheitern.

Das gilt auch für das Englische, freilich betont es eher die Verantwortung des Scheiternden. Denn die beiden häufigsten Wörter fail/failure und miscarry/miscarriage verweisen auf einen Mangel an persönlicher Kompetenz und Ausdauer bzw. auf ein Fehlverhalten. Diese pejorative Tendenz wird schon durch das negative Präfix in miscarry evoziert, ähnlich zu misbehaviour, das damit durchaus in Verbindung gebracht wird. Obschon miscarry/miscarriage bevorzugt zur Bezeichnung eines selbstverschuldeten Misserfolgs verwendet wurde, transportiert das Wort - wie das deutsche Scheitern - in seiner spezifischen Bedeutung aber auch tragische Konnotation, denn es bezeichnet eine Fehlgeburt.

Der frühneuzeitliche Sprachgebrauch weist somit im Deutschen wie im Englischen Ambiguitäten auf. In ihm scheint Kontingenz auf,

1 | Der Band geht auf eine Ringvorlesung der Fakultät für Geisteswissenschaften an der Universität Duisburg-Essen im Sommer 2013 zurück. 
die menschliches Handeln stets prekär macht und die im Scheitern besonders hart hervortritt. Der spezifische Umgang mit diesem zentralen Problem kann als ein Hinweis auf den Charakter einer Zeit aufgefasst werden; in den sprachlichen Veränderungen erkennen wir Indizien für den historischen Wandel schlechthin.

Stefan Brakensiek/Claudia Claridge 



\section{"A full Account of the rise, progress and declension of our Journal"}

Negotiations of failure in early English newspapers

\section{Birte Bös}

\section{INTRODUCTION}

In the first three decades of the $18^{\text {th }}$ century, the English newspaper landscape witnessed an unprecedented growth. For newsmakers, it was a time of experimentation, innovation and success, but - unavoidably - also failure. Clearly, the notion of failure is open to interpretation. Vivid evidence of how the newsmakers ${ }^{1}$ themselves viewed and negotiated failure is found in their papers, in self-referential passages, in which they position themselves and their papers.

Such editorial metadiscourse, i.e. "passages written ostensibly by the news editor or publisher as distinct from [...] reports written by various correspondents and reporters printed within the news publications"2 ${ }^{\text {, was }}$ generally much more frequent and comprehensive in those early days of news writing than it is today. Starting a new project, newsmakers would lay open their motivations, outline their plans, and express their hopes for success $^{3}$. However, some inaugural issues also discuss the failure of previous newspapers which resulted in new publication projects, the renaming and relaunch of existing ones, or the merging of newspapers. In the final

1 | The term 'newsmaker' is used here as an umbrella term for the voice representing the newspaper. In the early days of the newspaper, this voice would often stand for the author cum editor (and occasionally cum owner) of the paper. However, in many cases, a fictitious editorial persona represented the newspaper.

2 | Brownlees (2015), 5.

3 | Cf. Winkler (1998), 200-202. 
issues, certainly not surprisingly, metadiscourse is less frequent than in the inaugural issues. Not every newsmaker took the chance to comment on the closing of their publication, and thus, many papers disappeared from the market without a word. Still, newsmakers were not unlikely to deal with the (potential) failure of ceasing publication in their final edition. ${ }^{4}$

Those insightful comments form the basis of the qualitative analysis pursued in this paper to gain insights into conceptualisations of (newspapers') failure in the early $18^{\text {th }}$ century. After a short sketch of the contemporary newspaper landscape (section 2), which allows for a historical contextualisation of the study, section 3 will provide further information on the data and methods of analysis. Section 4 will focus on newsmakers' strategies of negotiating failure, which range from negating and reframing it to processes of self- and other-attribution. Finally, section 5 takes a closer look at the metaphorical domains exploited, which provide further evidence of how failure was conceptualised by early modern newsmakers.

\section{THE ENGLISH NEWSPAPER LANDSCAPE IN THE EARLY 18TH CENTURY}

Actually, it was failure that instigated the boom in the English newspaper market at the turn of the $18^{\text {th }}$ century. When the Licensing $\mathrm{Act}^{5}$ had lapsed in parliament in 1695 , the doors were opened for new print publications, ending the three decades of unrivalled supremacy of the London Gazette. ${ }^{6}$ The growth was furthered by the social and economic conditions of the time. The expanding middle class and the increasingly more literate working class yielded more diversified readerships which needed to be catered for. The conflict-laden political situation - both at home and abroad - pro-

4 | Additionally, certain changes in the newspaper market triggered editorial metadiscourse as well. Some such comments are included in this discussion (e.g. ex. 1 and 2 below). Yet, such a historical, event-based approach would certainly be worth more systematic investigation.

5 | "An Act for preventing the frequent Abuses in printing seditious treasonable and unlicensed Bookes and Pamphlets and for regulating of Printing and Printing Presses".

6 | Fries (2012), 53. 
vided ample material for discussions, to be fuelled by opposing newspapers and hotly debated in the flourishing coffeehouses. ${ }^{7}$

Right in 1695, the first tri-weeklies, the Post Boy, the Post Man and the Flying Post, started to appear. ${ }^{8}$ In 1702 , the first daily newspaper, the Daily Courant, entered the market, a publication format, which remained unrivalled for 17 years. The first evening paper, the Evening Post, made an attempt for daily publication, when it was first published in 1709 . Yet, after only a few weeks, it was cut down to tri-weekly publication. ${ }^{9}$ Still, the Evening Post and further evening papers that followed, were more successful than their morning competitors. They sped up news coverage, including the latest news of the day, before the papers were sent off to the country in the evening ${ }^{10}$. In addition to these papers, there were many short-lived publications, which hardly survived for a few weeks or months. ${ }^{11}$

A new direction of news writing was set by the publication of literary periodicals and political papers like Daniel Defoe's Review (1704), Richard Steele's Tatler (1709), Jonathan Swift's Examiner (1710), and Joseph Addison's Spectator (1711). Experimenting with new forms and styles (like the club motive and an inventory of fictitious correspondents), they "presented the reader with a ready-made form of public opinion on recent events"12, paving the way for the leading article.

Growth and diversification were drastically impeded by a series of Stamp Acts, which, when first introduced in 1712, raised a tax of $1 / 2 \mathrm{~d}$ or $1 d$, depending on the format of the paper. With every renewal of the Act, the taxes increased, reaching their peak in 1815 with $4 \mathrm{~d}$, before they finally were abolished in $1855 \cdot{ }^{13}$ Clearly, the taxes were not just introduced to raise money. In fact, Downie points out, the Stamp Act was designed to fund a lottery, which promised more money than the actual tax, but, more

\footnotetext{
7 | Clarke (2010), 49.

8 | Black (1987), 13.

10 | Clarke (2010), 50.

11 | For more details cf. Fries (2012).

12 | Clarke (2010), 56.

13 | Schneider (2002), 20-21.
}

9 | It is likely that this was a measure to avoid complete (financial) failure. Yet, as neither the first nor the last issues are available in the Burney Collection, no editorial metacomments discussing the reasons for this decision have been preserved. 
importantly, "it was also intended to reduce the amount of opposition propaganda that found its way onto the streets." ${ }^{14}$

Anyway, the taxes cost many newspapers their existence and stoked fears among the newsmakers. This is vividly expressed in the comments of contemporary authors like Jonathan Swift (ex. 1) ${ }^{15}$ and Joseph Addison (ex. 2).

(1) Do you know that Grub Street is dead and gone last week? No more ghosts or murders now for love or money. I plied it pretty close the last fortnight, and published at least seven penny papers of my own, besides some of other people's: but now every single half-sheet pays a halfpenny to the Queen. The Observator is fallen; the Medleys are jumbled together with the Flying Post; the Examiner is deadly sick; the Spectator keeps up, and doubles its price; I know not how long it will hold. Have you seen the red stamp the papers are marked with? Methinks it is worth a halfpenny, the stamping it. (Journal to Stella, letter 51, 7 Aug 1712) $)^{16}$

(2) This is the day on which many eminent authors will probably publish their last words. I am afraid that few of our weekly historians, who are men that above all others delight in war, will be able to subsist under the weight of a stamp and an approaching peace. [...] A facetious friend of mine, who loves a pun, calls this present mortality among authors, 'The fall of the leaf.' (Spectator, No. 445, 31 July 1712)

Indeed, the Spectator ceased publication on 6 December 1712, not without emphasising the ruinous effects of the Stamp Act in an editorial comment (cf. ex. 11 below). Yet, "tax or no tax, there was more general activity in journalism after 1712 than before"17, and in the 1730s, further new formats entered the market. For example, with the Daily Advertiser (1731), the first newspaper was published whose financing rested completely on advertising. The Gentleman's Magazine (1731), as a new type of weekly

14 | Downie (1979), 160.

15 | In all the examples, spelling and typeface are taken over from the original.

16 | http://ebooks.adelaide.edu.au/s/swift/jonathan/s97s/letter51.html (last accessed: 26 May 2013)

17 | Morison (1932), 84. 
journal, furthermore intensified the competition. ${ }^{18}$ Again, this damaging influence was discussed extensively in the editorial metadiscourse of papers suffering from it, most notably in the last issues of Grub-street Journal (22 and 29 December 1737), as will be illustrated in section 4.3.

\section{DATA AND MEthods}

The data for this study are taken from the $17^{\text {th }}-18^{\text {th }}$ Century Burney Collection Newspapers ${ }^{19}$, which is accessible online and provides the opportunity to download the relevant material in PDF-format. 70 editions of late $17^{\text {th }} /$ early $18^{\text {th }}$ century newspapers, particularly first and last issues, were scanned for metadiscursive evidence of negotiations of failure. 15 issues published between 1695 and 1737 were selected for the close-up, qualitative investigations pursued in this paper.

The relevant editorial metadiscourse takes different shapes and sizes. It ranges from short, mostly one-sentence passages informing about changes in the publication conditions, and "Addresses to the Public" comprising one to two columns, to highly complex discourses extending over one or more pages. It is hardly surprising that the longer and more explicit negotiations of failure are mainly observed in the 'opinionated press'. There, editors meticulously dissect the reasons for the discontinuation of the publication, they raise accusations against their enemies and refute their enemies' accusations against themselves. Repeatedly, they also promise to return to the newspaper market, yet, usually without any specification as to how and when, as illustrated by ex. (3).

(3) It is possible, however, that when our first Hurry of Business is a little over, I may have Leisure, more than enough, to talk on, as I have done hitherto: But under what Name or Shape, I shall make my Appearance, is a Matter I am wholly dark in. (Plain Dealer, 7 May 1725)

Occasionally, the last editions of newspapers also recycled material from other sources, as in the case of the Grub-street Journal, which devotes large

18 | Conboy (2010), 45-46.

19 | http://find.galegroup.com/bncn/start.do?prodld=BBCN\&userGroupName =duisburg\&finalAuth=true (last accessed 29 October 2014). 
parts of the last two issues to a reprint of the preface to the Memoirs of the Society of Grub-street, published a few months before (4 May 1737), and "giving a full Account of the rise, progress and declension of our Journal" (Grub-street Journal, 22 December 1737).

\section{Negotiating failure}

In the data, three major strategies of negotiating the (potential) failure of discontinuing a paper can be observed. In some cases, failure is negated or even reframed as success. When failure is admitted, self-attribution and/ or other-attribution can be observed.

\subsection{Negating and reframing failure}

Negating failure or even reframing it as success is obviously the most promising strategy to avoid face loss. Thus, some of the editorial metadiscourse investigated provides not much more than dry information on certain changes in the publication conditions (cf. ex. 4).

(4) WHereas I have for several Months published a News Paper call the Post Boy, and the Historical Account, I have now for some reasons, thought to continue my HISTORICAL ACCOUNT, by the same Author, with the additional Title of the POST MAN; and to give notice that what Advertisements shall be sent to me, shall be incerted in my News Paper as formerly, Richard Baldwin. (Post Man, And the Historical Account, QTc., 24 October 1695)

Here, the background of the publisher's decision is kept deliberately vague. Yet, as pointed out in the headnote on the Post Man given in the Burney Collection, Richard Baldwin's "split from the Post Boy (which had been printed for him until the issue of 17-19 October 1695) was apparently acrimonious". ${ }^{20}$

Similarly, it is only by studying the socio-historical context that it becomes clear that in the case of ex. 5 , the fusion was by no means a volun-

20 | Burney Collection, headnote on Post Man, And the Historical Account, \&c. 
tary decision by the Daily Courant and the other two papers mentioned, but ordered by Sir Robert Walpole's ministry. ${ }^{21}$

(5) The Authors of the several Political Letters in the London Journal, Free Briton, and this Paper, will, for the future, publish their Dissertations on Publick Affairs in a New Paper, entitled The DAILY GAZETTEER; the first Number of which will make its Appearance on Monday next. (Daily Courant, 28 June 1735)

By uniting the Daily Courant, the London Journal and the Free Briton, which had been loyal to and subsidised by the government, money could be saved, and greater control and wider reach could be achieved. A detailed account of the motivations for this move is given in the inaugural issue of the Daily Gazetteer, which replaced them. Obviously, the decision is sold there to the public in the best light, as

(6) owing to the amicable Agreement of several Authors, who having, for many Years past, been embarked in the same Cause, have at length resolved to unite in the same Paper, and by the most extensive Circulation, to publish their faithful Endeavours in Support of the general Interest. [...]

Our readers will have these Benefits from the Nature of this Institution, that the Vindication of publick Authority will be regularly carried on, in one distinct Paper; that the Hands which contribute to this Work, will succeed to each other Day after Day; and that no more than one will require Attention on any particular Day. To this we may add, that whilst we lessen the Charge of our Readers, we increase their Entertainment, and, on the whole, we can have no Cause to doubt their intire Approbation. [...]

THE Cause which we have undertaken is, to vindicate Publick Authority from the rude Insults of base and abusive Pens; to refute the Calumnies; and the injurious Clamours, of factious dishonest Men; to expose the Insincerity of Mock Patriots the little Arts and mean Practices of which they are notoriously guilty, in seducing Mankind, and misleading the People from their Duty to their Destruction [...] (Daily Gazetteer, 30 June 1735)

21 | Cf. Burney Collection, headnote on Daily Courant. 
Fusions were, of course, not just politically enforced, but often a result of financial problems of the old publications or of editorial decisions hard to reconstruct for the modern researcher. Anyway, it was generally an advantageous strategy to negate potential failure, and reframe the fusion as success, pointing out explicitly the benefits for readers and advertisers. Ex. 7, from the later $18^{\text {th }}$ century, aptly illustrates this lasting strategy. The comment was published in the last issue of The World before it merged with the Morning Post into the Morning Post and Fashionable World.

(7) To the Readers of both Papers this Union cannot but be deemed desirable, as all the talents and all the resources of both will be found in conjunction to defy every oppressed effort. Their several Correspondences from abroad, centering in one common focus, will form such a combination of wide spreading intelligence, as, perhaps, has never before been offered to the Public.

To Men of Business this Conjunction offers advantages still more important. They will be enabled to avail themselves of advertising in this United Property of Two Papers, both well-received and both well established, at half the expence which they must previously have incurred. The Junction, it is to be added, when completed, will form an amount of sale, which, if it were necessary to avow, would cause the most sanguine of their Rival's to shrink from Competition. Under these circumstances, the Proprietors are not only confident that they shall retain all their several Friends, but that they shall add immediately and considerably to their number. (World, 30 June 1794)

In this way, the positive self-image of the newsmakers was preserved and important promotional work for the new project was done. More evidence of this strategy of reframing (potential) failure as success can therefore also be found in the advertisements for new publications arising from old ones which were placed in other newspapers.

Positive self-presentation was boosted even more by newsmakers making reference to the devastating effects of certain circumstances or events, which, nevertheless, did not make them fail, but even improve their products. Thus, Nathaniel Mist, in the first edition of Mist's Weekly Journal (the successor of his Weekly Journal and Saturday's Post), ironically comments on the changes enforced by the Second Stamp Act (1725), which further increased the newspaper taxes (ex. 8). 
(8) As all Men, who have any Thing to do with the Publick, should render a strict Account of their Actions, I therefore, in my last, gave the Reasons why I was obliged to alter the Form and Price of my Journal. Since therefore it has pleased the Wisdom of the Legislature to think, that a considerable Sum of Money may be raised towards paying the Debts of the Nation, by this Paper; I, as a true Britain, and good Protestant, being desirous to ease my Fellow-Subjects of the Burden of some of their Taxes, by these my Labours, am resolved, henceforth, to exert my self in a more than ordinary Manner, towards making this Paper more diverting, as well as instructive, than heretofore, that, by the Sale it may answer all the Purposes design'd, that no Deficiencies may be hereafter found in the Supplies granted for the Year seventeen hundred twenty five; and that, at next Sessions of Parliament, the Tax on Soap, Candles, Leather, or some other Manufacture, which deserves Encouragement more than the Paper Trade, may be taken off, to the great Ease of the middling and poorer Sort of People. (Mist's Weekly Journal, 1 May 1725)

\subsection{Self-attribution of failure}

Rather rarely, newsmakers admitted that the reasons for the failure of their publication lay with themselves. Obviously, this can be related to the fact that "people have an instinctive tendency to deny, distort, ignore, or disassociate themselves from their own failures"22. This phenomenon is described in social psychology, within the framework of attribution theory, as self-serving bias. Whereas people typically regard their own achievements as results of their personal skills and efforts, they tend to consider negative outcomes as being caused by other people or external circumstances unforeseeable or beyond their control. ${ }^{23}$ This self-serving bias, Shepperd et al. explain, is caused by an interplay of motivational and cognitive aspects, including the strive for self-enhancement and a positive self-presentation, and people's sincere attempts to analyse the situation of failure and arrive at what appear to be objective interpretations.

Evidence of the self-serving bias can clearly be observed in our data. Predictably, there is not a single case, in which the newsmaker takes full

22 | Cannon/Edmondson (2005), 302.

23 | Shepperd/Malone/Sweeney (2008), 895-896. 
responsibility. If the newsmaker admits failure, this is typically combined with face-saving references to external causes of the paper's decay. For example, the editorial voice of the Freeholder acknowledges certain personal incapacities in his final edition (18 May 1723), yet not without providing a comprehensive account of the hardships and disadvantages he had suffered from (ex. 9).

(9) The Design and Counsel were good, but I was the Fool in undertaking to tye the Bell about the Cat's Neck. There is a Party in the World [...] that have betray'd Wiser Heads than Mine [...]

As I am not the first Man, who has mistaken an Ignis Fatuus for a true Light, and been led into the Mire, it is scarce worth my while to condole myself on the Misfortune. [...]

I am fully conscious of my own Disability. This Journal set out under the Disadvantage of a troubled Season. [...] (Freeholder, 18 May 1723)

Although these disclosures endanger his positive self-image, particularly the image of strength and independence, the newsmaker cleverly manages his self-presentation. He stages himself as a victim, modest and underprivileged, thus fishing for the compassion of his readers (see section 5.2 below for metaphorical representations of the newsmaker as a victim).

\subsection{External attribution of failure}

As already indicated in the previous section, failure was typically explained by referring to external, uncontrollable factors. Unfavourable circumstances are foregrounded by terms such as misfortune (Freeholder, 18 May 1723). Terms like mischief, unfairness and injustice, depredation and plunder (Grub-street Journal, 22 December 1737) point at the involvement of opposing forces.

The external reasons for failure claimed by the newsmakers can be grasped in two major scalar dimensions: specificity and personalisation. The degree of specificity varies from very vague allusions to explicit mentions of antagonistic circumstances and agents in the failure process. The degree of personalisation ranges from references to circumstances without or with an implication of responsible parties, via indications of institutions, groups and their representatives, to accusations of specific individuals. 
As regards the least personalised attributions, various circumstances are made responsible for failure. There are, as illustrated by ex. 9 above, references to the hard times and tense market conditions, the "Disadvantage of a troubled Season" (Freeholder, 18 May 1723). Unfairness and injustice are often pointed out without immediate personal references, as in the case of the Grub-street Journal (22 December 1737), which moans about "instances of falshood, folly and frenzy". Censorship is mentioned as a major obstacle, for obvious reasons, often without any specific, personalised references (ex. 10).

(10) [...] when the Liberty of a Subject or Writer is restrained, the Consequence must be to languish out the Remains of Life in a slow Decay. (Freeholder, 18 May 1723)

Yet, there are also references to specific events such as the introduction of the Stamp Acts, which, as already indicated above, triggered a substantial number of editorial comments (see also ex. 11 below).

On a more personalised level, references to all parties involved in the news production, distribution and consumption processes can be found. Again, the degree of specificity of such mentions varies. Indeed, the material includes few real names, neither in self- nor in other-reference, which can, of course, be related to the dangers of censorship and prosecution. Instead, the use of pseudonyms, abbreviated names and initials prevails. Occasionally, identities behind aliases and abbreviations are disclosed, yet not always explicitly ${ }^{24}$. Apart from that, we find generic person references like "Enemies" (Freeholder, 18 May 1723) and a range of metaphors such as "literary pirates" (Grub-street Journal, 22 December 1737), to be discussed in more detail in section 5 .

Table 1 illustrates the wide range of person references by drawing on a particularly rich instance of editorial metadiscourse published in the Grub-street Journal. The Grub-street Journal, described by contemporaries as "a newspaper universally condemn'd and yet universally read" (Weekly

24 | For example, the Spectator reveals: "All the Papers marked with a C, an L, an I, or an 0 , that is to say, all the Papers which I have distinguished by any Letter in the Name of the Muse CLIO, were given me by the gentleman, of whose Assistance I formerly boasted in the Preface and concluding Leaf of my Tatler." [i.e. Joseph Addison] (Spectator, 6 December 1712). 
Register 8 July 1732) ${ }^{25}$, obviously had a substantial number of opponents to confront at their termination. As the main culprit, it made out one of its competitors, the Gentleman's Magazine and its maker Edward Cave (alias Sylvanus Urban), who was accused of imitation, plagiarism, and deceptive practices. Indeed, the successful concept of the Gentleman's Magazine was to provide "a digest of texts and extracts from various London newspapers and periodicals" ${ }^{26}$, including material from the Grub-street Journal. Cave's spheres of control, the Grub-street Journal insinuated, extended to the post and stamp offices, and the booksellers. ${ }^{27}$ Yet, the newsmakers of the Grub-street Journal did not just make their rival papers responsible for their failure, they also did not shy away from blaming the readers (though indirectly), and disappointed correspondents, whose works were not accepted by the paper.

Table 1: Parties accused for failure in the final issues of the Grub-street Journal (1737)

\begin{tabular}{|l|l|}
\hline Competing papers & $\begin{array}{l}\text { "the declension of our Journal, and of all the rest, was } \\
\text { oweing to the rise and progress of the Gentleman's Mag- } \\
\text { azine [...] The Projector of this Magazine (who, having } \\
\text { blown up so many Papers with the powder stolen from } \\
\text { them, deserves the name of Chief Engineer of Grub-street) } \\
{[\ldots] \text { our industrious Brother SyLVANUs URBAN..." (22 De- }} \\
\text { cember 1737) }\end{array}$ \\
\hline Booksellers & $\begin{array}{l}\text { [paper was] "continually opposed and depreciated by the } \\
\text { generality of Book-sellers, and their hackney Authors" (22 } \\
\text { December 1737) }\end{array}$ \\
\hline Printers & $\begin{array}{l}\text { "our Advertisements...were refused by the printers of oth- } \\
\text { er Papers" (22 December 1737) }\end{array}$ \\
\hline
\end{tabular}

25 | Cf. Burney Collection, headnote on Grub-street Journal.

26 | Taavitsainen (2015), 145.

27 | Paradoxically, even the last two issues of the Grub-street Journal still contained advertisements for the Gentleman's Magazine. 


\begin{tabular}{|c|c|}
\hline $\begin{array}{l}\text { Officials } \\
\text { - Post office }\end{array}$ & $\begin{array}{l}\text { "very frequently other Journals were sent from the Post- } \\
\text { office, to persons who had given particular order for ours" } \\
\text { (22 December 1737) }\end{array}$ \\
\hline - Stamp office & $\begin{array}{l}\text { "that the Commissioners of the Stamp-office would effec- } \\
\text { tually put a stop to it, by procuring the Pamphlet [of the } \\
\text { competitor] to be stamped, as in justice it ought to have } \\
\text { been. But we were intirely mistaken" (22 December 1737) }\end{array}$ \\
\hline Readers & $\begin{array}{l}\text { "That any number of readers of the higher class would } \\
\text { give incouragement to the sale of such stolen goods [i.e. } \\
\text { the digest of news in the Gentleman's Magazine, BB], we } \\
\text { could not well imagine. [...] But we were intirely mistaken" } \\
\text { (22 December 1737) }\end{array}$ \\
\hline Correspondents & $\begin{array}{l}\text { "it was frequently a matter of wonder to him [the editor, } \\
\text { BB], that they [the correspondents, BB] could so far mis- } \\
\text { take the design of the Paper, as to imagine that it could } \\
\text { give admission to their lewd or profane compositions..." - } \\
\text { "some...have abused us for refusing to complie with their } \\
\text { desires" (29 December 1737) }\end{array}$ \\
\hline
\end{tabular}

Clearly, the self-serving bias interlinks with the 'us vs. them' principle. Thus, newsmakers typically contrast their positive self-presentation with negative other-presentations. For example, in the case of the Grub-street Journal, unfavourable characterisations of opponents (see Table 1) are juxtaposed with affirmations of the paper's "own integrity" (29 December 1737). The newsmakers take substantial efforts to polish their own image. They meticulously list accusations made by adversaries and refute them, justifying the criticised procedures "to shew the disparity betwixt their conduct, and ours" (22 December 1737).

Similar attempts to restore the positive self-image can be observed in the last issue of the Spectator, where Richard Steele finishes his editorial comment by pointing out the success of "an Edition of the former Volumes of Spectators", yet not without being critical about the destructive effect of the First Stamp Act (ex. 11). 
(11) above Nine thousand each Book is already sold off, and the Tax on each half Sheet has brought into the Stamp-Office one Week with another above $20 \mathrm{l}$. a Week arising from this single Paper, notwithstanding it at first reduced it to less than have the number that was usually Printed before this Tax was laid. (Spectator, 6 December 1712)

As pointed out by Cannon and Edmondson, who deal with failure in modern organisations, successful failure management involves "three distinct but interrelated processes: identifying failure, analyzing failure, and deliberate experimentation" ${ }^{28}$ Attempts to pursue these steps are clearly manifested in the metadiscourse found in historical newspapers. Occasionally, the reader is called upon as a witness of these processes (ex. 12).

(12) From all the aforesaid Considerations my Readers may expect that I shall be smarter than before. (Mist's Weekly Journal, 1 May 1725)

Indeed, many newsmakers apparently managed to "take advantage of the lessons that failures offer"29, coping with setbacks and starting anew, when one of their old publications had failed.

\section{Metaphorical conceptualisations of failure}

The examples used so far have already suggested that editorial metadiscourse negotiating failure shows a distinct preference for similes, metaphors and even complex allegories. This section provides a more in-depth investigation of what the metaphors used reveal about the mindset of contemporary newsmakers.

As pointed out in the seminal work by Lakoff and Johnson, metaphors are much more than rhetorical figures, shaping "the way we think" and thus being vital "in defining our everyday realities". ${ }^{30}$ Metaphors are defined here, in the light of cognitive linguistics, as involving a source concept and a target concept in a particular mapping scope, which provides the base of comparison. From the source concept, not only individual

28 | Cannon/Edmondson (2005), 300.

29 | Ibid.

30 | Lakoff/Johnson (1980), 3. 
properties, "but the structure, the internal relations or the logic of a whole cognitive model" are transferred to the target concept. ${ }^{31}$ Additionally, metaphors do not just work through the comparison of similarities and dissimilarities of the concepts, but also through hiding particular elements from the discussion. ${ }^{32}$

Metaphors can thus be considered as "manifestations of particular ideologies and world views"33, and "as framing devices to shape wider opinion". ${ }^{34}$ In our case, this means that the readership is inclined to view failure through the specific metaphorical lens of the newsmaker, which gives salience to particular facets and enforces particular interpretations of the affairs. ${ }^{35}$

Looking at the metaphors in our data, we find evidence of elementary root analogies such as SUCCESS IS UP, FAILURE IS DOWN ${ }^{36}$, which draws on orientational schemata resting on basic bodily experiences. ${ }^{37}$ This spatial conceptualisation of failure is aptly illustrated by the quote provided in the title of this paper, which furthermore indicates a processual perspective of "rise, progress and declension" (Grub-street Journal, 22 December 1737). This orientational metaphor ${ }^{38}$ is so fundamental in nature that it has, for example, also been found quite typical of modern business discourse. ${ }^{39}$

The generic concept that the negotiations of failure in $18^{\text {th }}$-century newspapers draw on most heavily is the PERSON concept. As visualised in Fig. 1, it is embedded in the basic conceptualisation of the news sector (inflicted by censorship and competition) as a DANGEROUS PLACE. Both these major metaphorical domains encourage various layers of partly overlapping metaphors, most centrally the victimisation of newspapers/newsmakers, which are discussed and illustrated below.

31 | Ungerer/Schmid (2006), 119.

32 | Cf. Tourish/Hargie (2012), 1048 and Goatly (2011), 2.

33 | Cf. Smith/Eisenberg (1987), 369.

34 | Tourish/Hargie (2012), 1046.

35 | Cf. Entman (2004), 5.

36 | Following the conventions of cognitive linguistics, cognitive metaphors are marked by small caps in this paper.

37 | Goatly (2011), 49, and Ungerer/Schmid (2006), 119.

38 | Lakoff/Johnson (1980),14.

39 | Partington (1998), 112. 
Figure 1: Major metaphorical conceptualisations observed in negotiations of failure in 18th-century editorial metadiscourse

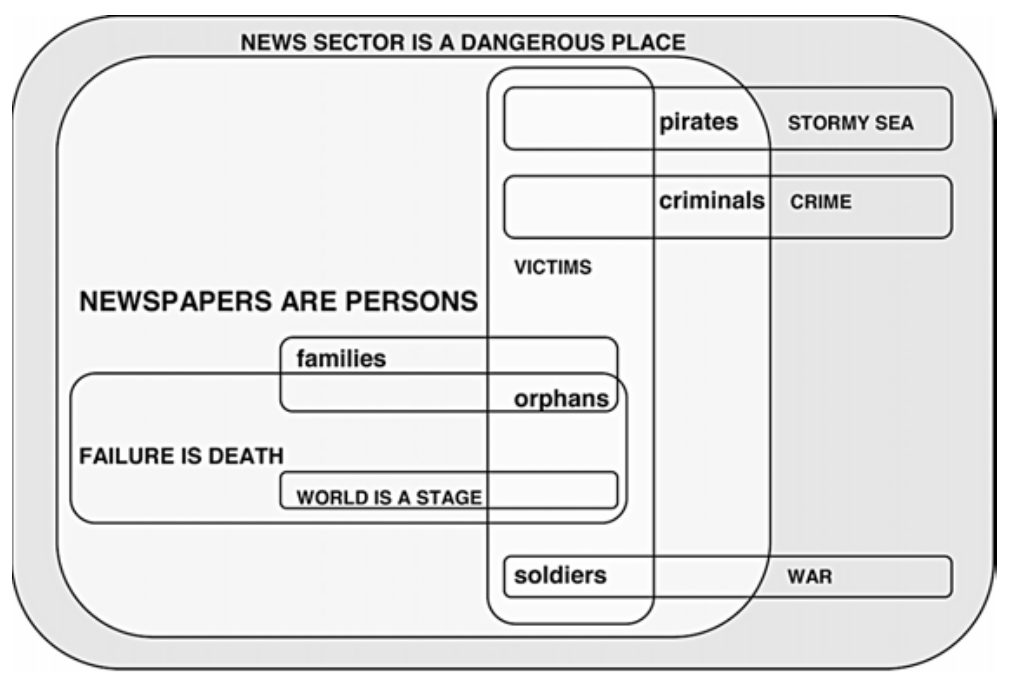

\subsection{Personification}

Personification "allows us to comprehend a wide variety of experiences with nonhuman entities in terms of human motivations, characteristics, and activities". ${ }^{40}$ Thus, it does not come as a surprise that the generic metaphor A COMPANY IS A PERSON ${ }^{41}$ has long been in widespread use and belongs, for example, to the recurring metaphors in modern business journalism. ${ }^{42}$

What is special about the personification of early English newspapers is that it was often reinforced by the titles of the papers - person references of various kinds - and their reporting style. As is well-known, "[t]he editor or 'author' of an early periodical usually wrote as if he were that journal's voice". ${ }^{43}$ The newsmakers embodied the Plain Dealer, the Examiner or the Spectator, and with those names, specific approaches to news presentation were implied. This setup helped to establish an air of immediacy and thus

40 | Lakoff/Johnson (1980), 33.

41 | Cf. Ungerer/Schmid (2006), 258.

42 | Partington (2006), 269.

43 | Downie/Corns (1993), 5. 
contributed to what modern Critical Discourse Analysis refers to as 'synthetic personalisation'. ${ }^{44}$

As even acknowledged by some of the newsmakers themselves, such personifications conveniently allowed newsmakers to hide behind their narrative persona: "It is much more difficult to converse with the World in a real than a personated Character" (Spectator, 6 December 1712). Obviously, this was a particularly important benefit at times of extensive censorship.

Given the particular state of the newspapers in questions, the notion of FAILURE IS DEATH clearly offers itself as a most fruitful metaphorical domain, which is embraced by the newsmakers in comprehensive and creative ways. This is vividly illustrated by the following extracts from the last issue of the Freeholder (ex. 13).

(13) THE Advance of the Season, and the Crowd of Papers that incumber the Town, and make the Tables of our Coffee-Houses look like the Counters of a Pamphlet Shop, perswade me that it is high Time $M Y$ Paper should die: Let its Enemies, therefore exult in Triumph, and cry in their Transports, The FREEHOLDER is now no more. It has been dead sometime in its political Capacity [...]

However, though I drop the Character of the FREEHOLDER for the present, I do not abdicate my future Claim [...]

I say this by way of Caution, that though I give out my self to be dead, the World may not depend upon the truth of it [...]" (Freeholder, 18 May 1723)

Here, the newspaper is personified throughout the editorial metacomment, however, the identity of the resulting persona is not consistent. At the beginning, there is still a clear division of the newspaper and the editor's voice. The newsmaker first simply assigns human qualities to the publication ("My Paper should die") as typically done in personification. Next, he even emphasises the fictitious nature of the newspaper's voice, emphasising his power over it ("I drop the Character of the FREEHOLD$\mathrm{ER}^{\prime \prime 5}$ ). However, towards the end of the metadiscursive passage, there is a shift in viewpoint. There, the newsmaker takes a first-person perspective

44 | Fairclough (2001).

45 | This example includes another conceptualisation of failure as DOWN. 
("though I give out my self to be dead"), thus blurring the differentiation indicated before, and he suggests that, similar to Pythagoras who feigned death and returned to life, he might return to the public. The concepts of feigned death and post-mortem messages (as in the next example) help the newsmakers to preserve their voices, enabling them (without violating the logic of the metaphor) to comment on the discontinuance of their publication and leave open the chance to start a new project.

Within the realm of the DEATH metaphor, political criticism and the newsmaker's editorial legacy could elegantly be presented in the form of a will, as in the case of ex. 14, which is metaphorically so rich that only selected aspects can be highlighted here. It is taken from the first edition of Fog's Weekly Journal, the successor of Mist's Weekly Journal. Fog's Weekly Journal was officially published by Charles Molloy after Nathaniel Mist had to flee to France in 1728 to escape prosecution for publishing the 'Persian Letter', a (barely) allegorically disguised attack on the ministry. ${ }^{46}$ Yet, in fact, Mist ran the paper "by remote control" from France. ${ }^{47}$ The pun in the changed title is quite straightforward.

(14) Dear Cousin FOG,

THE Occasion of my present Address to you, is to acquaint you, that I was lately seiz'd with an Apoplectick Fit, of which I instantly died: However, you need not be startled at receiving a Letter from the other World, for you may perceive it does not smell of Brimstone, by which you will conjecture, that it comes from the Temperate Side of Elysium. I was so suddenly snatch'd off, that I had not Time to make my Will, therefore I have been oblig'd to do it since. It is no strange Thing in your World for a Man to make his Will after his Death: - A thorough-paced Attorney will tell you there is nothing easier in the whole Course of Practice.

Amongst all my Relations, I have cast my Eyes on You to be my Heir, and the Executor of my last Will and Testament [...]

I think it is necessary to say something of our Family, that the World may know who we are. --- The Mists and Fogs (Time out of Mind) have

46 | Cf. Burney Collection, headnote on The weekly journal: or Saturday's post, with freshest advices foreign and domestick.

47 | Clarke (2010), 67; cf. also Conboy (2010), 44. 
been very considerable in Lincolnshire, where they had a strong Influence, the greatest part of the Country being under their Command [.] The Family of the Mists is extinct in me; but I thought it necessary to say thus much of our Ancestry, that you who are now the Representative of both Families, may the better know how to support our Character and imitate our Example, since I desire that you will succeed me in the publick Character of a Writer, which Character I have many years maintain'd to the great Entertainment, and Edification of my Countrymen. [...]

You will have an Advantage over all your Cotemporaries, of receiving frequent Intelligence from this World of ours, for none of the Writers of the other Side, have any Correspondence with that Part of Elysium, which is the Retreat of Heroes.-

(Fog's Weekly Journal, 28 Sept 1728)

This comment, in an epistolary format, draws on a range of metaphorical sources, most notably the FAMILY concept. Mist manufactures a detailed picture of family relationships between the Mists and the Fogs. In the context of the DEATH metaphor, the succeeding editor is conceptualised as his heir, responsible for the execution of his will. In other newspapers, similar metaphorical constructions additionally evoke the image of the readers as 'orphans' left behind (eg. Freeholder, 18 May 1723).

In addition to the legal framework constructed, religious allusions are made. Again, this is not uncommon, and can also be found in other editorial metacomments. ${ }^{48}$ What is special here is the somewhat unusual connection of "brimstone" and "Elysium". Whereas "the smell of brimstone" unmistakably transports a reference to hell fire (which might not be surprising, given the background of Nathaniel Mist as a committed Jacobite), the notion of "the Temperate Side of Elysium" constitutes a shift to the Greek mythological conceptualisation of afterlife. ${ }^{49}$ Mist thus places himself in the company of Gods and heroes; he pictures himself as enjoying his afterlife in the Elysian fields (and even pursuing his professional

48 | For example, the editorial voice of the Freeholder claims: "I believe I may be indulg'd in not confessing my Sins in the Administration of this Journal" (Freeholder, 18 May 1723).

49 | Felton (2010), 92-93. 
vocation from there). A more profound positive self-presentation than this is hardly possible.

Death, we learn from the letter, came suddenly and was a consequence of sickness, an "Apoplectick Fit". Such HEALTH metaphors are, again, quite conventional and still in common use in reference to the state of businesses today. ${ }^{50}$ In the case of our editorial metadiscourse, they provide the newsmakers with a further chance to disguise their criticism of the destructive effects of censorship under a metaphorical veil.

The DEATH metaphor triggers further metaphorical conceptualisations on subordinate levels. For example, various newsmakers make use of the WORLD IS A STAGE metaphor, another highly conventionalised metaphor (ex. 15, 16).

(15) "it is high time for the Spectator himself to go off the stage. [...]" (Spectator, 6 December 1712)

(16) "a Man, when he is going off from the Stage of the World, is taken Notice of by his last dying Words." (Freeholder, 18 May 1723)

Obviously, this conceptualisation only works out when framed by the NEWSPAPER IS A PERSON metaphor, and evokes elements such as the famous dying speeches, used here (in ex. 16) to justify the editorial metadiscourse.

However, there are also less negatively connotated metaphorical constructions. For instance, the FAMILY concept is used without the DEATH component in ex. 17, taken from the last issue of the Tory essay paper The Plain Dealer. As many of its contemporaries, this paper relied heavily on an inventory of fictional characters, compiled by the author cum editor, Aaron Hill. Most importantly, there is the "Plain Dealer" himself, a certain Edward Blunt, a 63-year old bachelor, and Martha Amble, his female counterpart. ${ }^{51}$

(17) No longer ago than Yesterday Morning, there was nothing farther from my Thoughts than the Discontinuance of my Weekly Labours: But, about an Hour before Dinner, all my Purposes received new Co-

50 | Cf. Partington (2006), 118.

51 | Wilputte (2008). 
lours; and, I am, now, no longer what I was, before this short Billet metamorphos'd me.

Dear Slavy,

AT length, I have determin'd, to be only yours, for ever, and, in Gratitude for all those, scarce deserv'd, fine Things, your Letter of last Week, oblig'd me with, I will say after you, next Saturday Morning, whatever Words you wish most ardently to hear me answer in.-But this is absolutely, upon Condition, that you put an End, immediately, to your Plain-Dealing. It is the most odious Quality you have, and, you know, I could never bear it.-I have given you, perhaps, too short a Warning; but you must do as well as you can: For, pray Heaven I hold in the Mind, if you take me not in the present Humour, of

Your Mistress, one Day more, and then, alas! your Servant, MARTHA AMBLE.

IT would be unreasonable for any of my Christian Readers to expect a better Excuse than This, for my taking Leave of them, so abruptly.

(Plain Dealer, 7 May 1725)

Projecting marriage as a reason for discontinuing the paper is clearly more original than the DEATH and HEALTH metaphors found elsewhere. Of course, the linguistic and historical contexts suggest other than romantic reasons for this step. For example, the final issue contains a taunting poem on Sir Robert Walpole, which the newsmaker introduces with the comment: "Where the Subject is a Minister of State, The fittest Person to treat of it, must be one, who ceases to be a Plain DeALER". Additionally, it might not be a coincidence that the Plain Dealer ceased publication just after the Second Stamp Act had raised the taxes again.

While personification is clearly the most prominent metaphorical conceptualisation, the attractive principle of animacy is also taken up in ANIMAL and (less frequently) in PLANT metaphors. One of these is illustrated in ex. 18, where the Grub-street Journal complains about its competitor The Bee, exploiting the paper's title in puns, similes and metaphorical references to its makers.

(18) [The Bee] ought to have been entitled The Drone's Collection: a very short and proper description of a Magazine, the compilers of which live like drones, upon the pillaged labours of the ingenious and in- 
dustrious [...] having buzz'd and humm'd about in a wretched and expensive manner (Grub Street Journal, 22 December 1737)

\subsection{Victimisation}

As pointed out in section 4.2, the attribution of failure to external circumstances appears to be deeply rooted in people's psyche. Thus, some strategies of negotiating failure have stayed remarkably stable. For example, Tourish and Hargie observed in a study on bankers' post-crisis communication strategies after the financial crisis in 2008 that among the four major, interrelated defence strategies was their presentation as "passive observers when confronted by market forces beyond human agency", "as victims", and " as penitent learners, rather than pedagogues". ${ }^{52}$ While evidence for the latter strategy is scarce in my data ${ }^{53}$, the former two are vividly manifested in the editorial metadiscourse. There is an overarching conceptualisation of newsmakers/newspapers as passive observers or victims of opposing forces of various kinds. Zeitgeist is reflected in the choice of metaphors characterising the NEWS SECTOR AS A DANGEROUS PLACE of competition and censorship.

The notion of the STORMY SEA can, of course, be considered a classical metaphorical resource. In the $18^{\text {th }}$ century, at a time of naval power and exploration, the conceptualisation of the newspaper as a BOAT IN A STORMY SEA, tossed about by uncontrollable forces, proved a fruitful picture (cf. ex. 19).

(19) When the Weather is too boisterous, little Boats cannot live upon the Sea. I know my Vessel to be too weak to buffet the Storms of Power; and the Sky is not serene enough, to induce me not to make the Porte. (Freeholder, 18 May 1723)

Another recurring conceptualisation suggested that COMPETITION Is CRIME and competitors are criminals. It triggered different metaphorical realisations (e.g. as piracy, theft, plunder, and fraud), and generally relied

52 | Tourish/Hargie (2012), 1052-1054.

53 | But see this example: "For my own Part, I sit down with this Lesson, that [...]" (Freeholder, 18 May 1723). 
on the basic notion that IDEAS [NEWS] ARE COMMODITIES. ${ }^{54}$ The prominence of such metaphors of unlawful dispossession can be explained by the fact that, at that time, news was still scarce and newsmakers often fell back on material from other newspapers to fill their pages, in what Black called a "scissors and paste" technique. ${ }^{55}$

With the notion of PIRACY, as displayed in references to the "piratical traffic" and "piratical adventures" of "Literary Pirates", i.e. the paper's competitors (Grub-street Journal, 22 December 1737), newsmakers stayed in the naval domain. Everyday life associations are evoked in metaphorical representations of the copying of news items, but also innovative practices of news writing, as stolen utilitarian goods. Ex. 20 compares the practice of digesting news from other papers employed by the Gentleman's Magazine to the activities of petty criminals trying to disguise their theft.

(20) [...] as stolen linen, handkerchiefs, \&c. are rendered the fitter for sale, by taking out the mark of the owner's name (Grub-street Journal, 22 December 1737)

The allegedly bad quality of competitors' newswriting is also compared to stolen or spoiled food items, thus drawing on the basic conceptualisation IDEAS [NEWS] ARE FOOD ${ }^{56}$, as illustrated by the detailed simile in ex. (21). Here, the newsmakers of the Grub-street Journal defend themselves against their rivals' complaints about the journal's smear campaigns. While their news is characterised as fake without any substance, the competitors are pictured as deceitful street hawkers. Again, the us vs. them contrast is reinforced by explicit mentions of the newsmakers' own positive qualities.

(21) Suppose we were standing at the bow-window at the Pegasus, and saw an Inmate of Grub-street driving ginger-bread in a wheel-barrow, and oratorically advertising and puffing the excellency of it; which, tho' adorned with curious figures and flowers, and with letters in gold, (like a book finely bound, letter'd, and gilt) we certainly knew, either to be stolen, or to be composed of worthless and ob-

54 | Cf. Lakoff/Johnson (1980), 47.

55 | Black (1992), 14.

56 | Cf. Lakoff/Johnson (1980), 46 and Goatly (2011), 49. 
noxious ingredients, which at best could yield no nourishment, and might probably occasion some distemper; would it be any instance of malice and ill nature, to give the audience a true information, and to advise them to preserve their money and their health? Nay, would it not be an evident instance of benevolence and good nature towards them; tho' the Ginger-bread-maker and seller would no doubt loudly complain of it as ill-natured and malicious?" (Grub-street Journal, 29 December 1737)

A third forceful conceptualisation found in the material is the notion that the news sector is a battlefield where hazardous wars are being fought. Nathaniel Mist, the proficient user of metaphors, used this metaphorical source domain of WAR, when he commented on the changed publication conditions of Mist's Weekly Journal, which had to appear in reduced form after the introduction of the Second Stamp Act (ex. 22).

(22) while I look on my self in this new Dress, the Gracefulness of my Figure seems to suffer some Diminution from the Change: Methinks I look like some veteran Soldier, who, by the Misfortunes of War, had lost a leg and an Arm in the Service of his Country. - Yet I comfort my self with this Reflection, that tho' this Mutilation impairs the Beauty of such, they are look'd upon with more Respect. Upon which Consideration I am resolved, that if, for the Good of my Country, it should be resolved, by any future Act, to cut me off another Limb and oblige me to appear in half the Quantity of Paper in which I am now seen, I shall not quit the Field; [...]

I shall never be able to draw up a great Army, and fight a pitch'd Battle within the Compass of this small Paper (Mist's Weekly Journal, 1 May 1725)

This metadiscourse provides a rich metaphorical conceptualisation of the editorial persona, representing the newspaper, as a soldier who - despite having suffered from the hardships and harms of war - is a successful survivor, not to be stopped by the mutilations inflicted on him. As also shown in many of the previous examples, the metaphorical domains exploited tend to overlap, allowing for enriched metaphorical conceptualisations of causes and consequences of (potential) failure. 


\section{Conclusion}

$18^{\text {th }}$-century newsmakers did not shy away from commenting on the discontinuance of their publication projects, particularly in their last issues, but also in the inaugural editions of follow-up publications. Yet, as this investigation of editorial metadiscourse in early English newspapers has shown, they did not necessarily admit failure. In order to preserve a positive self-image, strategies of denying or reframing failure were applied, which even sold potential failure as success to the public, claiming, for example, that the new papers resulting from the relaunch or fusions of old ones promised improved news coverage and wider audiences.

The self-serving bias, described in modern social psychology, helps us to understand how failure - if it was acknowledged - was negotiated. Instead of admitting personal mistakes, newsmakers typically made external factors responsible for ceasing publication. References to such external causes were manifold and varied in their degrees of precision (from very vague to highly explicit) and personalisation (from relating to general conditions to pinpointing individual opponents).

A closer look at the figurative language employed in negotiations of failure reveals that - just as the self-serving bias - basic metaphorical conceptualisations appear to have stayed remarkably stable over time. However, their particular realisations indicate contemporary specifics. Thus, there was, for instance, ample evidence of the COMPANY IS A PERSON metaphor which is still in frequent use in business journalism today. However, what made its use special and allowed for rich, multi-layered exploitations of the concept in early English news discourse, is the presence of an editorial persona, which was very common in $18^{\text {th }}$-century newspapers, as indicated by the person references that frequently served as their titles. The presence of these often fictitious, well-developed editorial personae representing the newspaper opened up further layers of metaphorical domains, most notably (for obvious reasons) the DEATH metaphor, which could be exploited in much breadth and depth. The dangers of the news sector such as competition and censorship - were, for example conceptualised in NAVAL, CRIME and WAR metaphors. Newsmakers, and this is a link to modern conceptualisations of business failure again, predominantly took the position of passive observers of uncontrollable circumstances or victims of opposing forces. 
The analysis of editorial metadiscourse opens up an interesting perspective on strategies and metaphors of negotiating of failure in early English newspapers. Yet, as indicated in the discussion, these can only be appreciated by considering the socio-historical contexts and social psychological phenomena. Thus, this paper underlines once more the necessity of interdisciplinary approaches, which deserve further promotion in future research.

\section{BIBLIOGRAPHY}

Black, Jeremy (1987): The English Press in the Eighteenth Century, London-New York.

Black, Jeremy (1992): “The eighteenth century British press”, in: Griffiths, Dennis (ed.): The Encyclopedia of the British Press 1422-1992, Basingstoke, 13-23.

Brownlees, Nicholas (2015): “'We have in some former bookes told you': The significance of metatext in $17^{\text {th }}$-century news", in: Bös, Birte/ Kornexl, Lucia (eds.), Changing Genre Conventions in Historical English News Discourse, Amsterdam-Philadelphia, 3-22.

Cannon, Mark D./Edmondson, Amy C. (2005): "Failing to learn and learning to fail (intelligently): How great organizations put failure to work to innovate and improve”, in: Long Range Planning 38, 299-319.

Clarke, Bob (2010): From Grub Street to Fleet Street. An Illustrated History of English Newspapers to $1899,2^{\text {nd }}$ rev. ed, Brighton.

Conboy, Martin (2010): The Language of Newspapers. Socio-Historical Perspectives, London.

Downie, James A. (1979): Robert Harley and the Press: Propaganda and Public Opinion in the Age of Swift and Defoe, Cambridge.

Downie, James A./Corns, Thomas N. (eds.) (1993): Telling People What to Think. Early Eighteenth-Century Periodicals from The Review to The Rambler, London.

Entman, Robert (2004): Projections of Power: Framing News, Public Opinion, and U.S. Foreign Policy, Chicago.

Fairclough, Norman (2001): Language and Power, $2^{\text {nd }}$ ed., London.

Felton, Debbie (2010): “The Dead”, in: Ogden, Daniel (ed.): A Companion to Greek Religion, Oxford, 86-99. 
Fries, Udo (2012): “Newspapers from 1665 to 1765”, in: Facchinetti, Roberta/Brownlees, Nicholas/Bös, Birte/Fries, Udo: News as changing texts: Corpora, methodologies and analysis, Newcastle, 49-90.

Goatly, Andrew (2011): The Language of Metaphors, $2^{\text {nd }}$ ed., London.

Lakoff, George/Johnson, Mark (1980): Metaphors We Live BY, Chicago-London.

Morison, Stanley (1932): The English Newspaper. Some Account of the Physical Development of Journals Printed in London between 1622 Q $\mathrm{Q}$ the Present Day, Cambridge.

Partington, Alan (1998): Patterns and Meanings. Using Corpora for English Language Research and Teaching, Amsterdam-Philadelphia.

Partington, Alan (2006): "Metaphors, motifs and similes across discourse types: Corpus-Assisted Discourse Studies (CADS) at work”, in: Stefanowitsch, Anatol/Gries, Stefan Th. (eds.): Corpus-Based Approaches to Metaphor and Metonymy, Berlin-New York, 267-304.

Schneider, Kristina (2002): The Development of Popular Journalism in England from 1700 to the Present. Corpus Compilation and Selective Stylistic Analysis, Rostock.

Shepperd, James/Malone, Wendi/Sweeney, Kate (2008): “Exploring Causes of the Self-serving Bias”, in: Social and Personality Psychology Compass 2/2, 895-908.

Smith, Ruth C./Eisenberg, Eric M. (1987): “Conflict at Disneyland: A Root-Metaphor Analysis", in: Communication Monographs 54/4, 367380 .

Taavitsainen, Irma (2015): "Medical news in England 1665-1800 in journals for professional and lay audiences”, in: Bös, Birte/Kornexl, Lucia (eds.): Changing Genre Conventions in Historical English News Discourse, Amsterdam-Philadelphia, 135-159.

Tourish, Dennis/Hargie, Owen (2012): “Metaphors of Failure and the Failures of Metaphor: A Critical Study of Root Metaphors used by Bankers in Explaining the Banking Crisis”, in: Organization Studies 33 (8), 1045-1069.

Ungerer, Friedrich/Schmid, Hans-Jörg (2006): An Introduction to Cognitive Linguistics, $2^{\text {nd }}$ ed., Harlow.

Wilputte, Earla (2008): "Midwife for the Mind: Delivering the Passions in Aaron Hill's The Plain Dealer (1724)”, in: Journal for Eighteenth-Century Studies 31/1, 1-15.

Winkler, Karl Tilman (1998): Wörterkrieg, Stuttgart. 



\title{
Projektemacher
}

\author{
Zum Hintergrund ökonomischen Scheiterns \\ in der Frühen Neuzeit
}

\author{
Stefan Brakensiek
}

\section{Einleitung}

Scheitern kann nur, wer Pläne hat. Die Beschäftigung mit dem Thema Scheitern ist also zugleich eine Beschäftigung mit der Frage, wie sich Menschen ihre Zukunft vorstellen, wie sie diese Zukunft gestalten wollen, und wie sie damit umgehen, wenn sie mit diesen Plänen keinen Erfolg haben. Im Diskurs des 17./18. Jahrhunderts wurde für ambitionierte Pläneschmiede der Begriff »Projektemacher« geprägt. Dass solche Projektemacher scheiterten, war zwar keineswegs eine ausgemachte Sache. Der zeitgenössische Diskurs legt jedoch den Gedanken nahe, dass ein Scheitern wahrscheinlicher war als ein Erfolg. Dass dennoch die Kette der Projekte nicht abriss, kann als ein Hinweis auf spezifische, für die Epoche typische Haltungen und Handlungsweisen gedeutet werden. Entsprechend hat die aktuelle kulturwissenschaftliche Forschung im frühneuzeitlichen Projektemacher eine sozio-kulturelle Figur identifiziert, die in ihrer Zwiespältigkeit auf die Moderne verweist. In diese Richtung argumentiert bereits ein Artikel des Germanisten Georg Stanitzek aus dem Jahr 1987, dessen Verdienst darin besteht, den Projektemacher für die Forschung überhaupt entdeckt und die schillernde Bedeutung des Begriffs erstmals herausgearbeitet zu haben. ${ }^{1}$ Im Jahr 2004 haben sich etwa ein Dutzend Kulturwissenschaftler in dem Sammelband »Projektemacher. Zur Produktion von Wissen in der Vorform des Scheiterns « ${ }^{2}$

1 | Stanitzek (1987).

2 | Krajewski (2008). 
einerseits mit der frühneuzeitlichen Gestalt befasst, andererseits mit dem Projektemacher als aktuellem »postmodernen Massenphänomen « ${ }^{3}$.

Daran anknüpfend soll über den Stellenwert der Projektemacherei im ökonomischen und politischen System der frühen Neuzeit nachgedacht werden. Hierzu werden zwei Herangehensweisen gewählt, die sich gegenseitig kommentieren: Zum einen werden die beiden bedeutendsten deutschsprachigen Enzyklopädien des 18. Jahrhunderts ${ }^{4}$ daraufhin durchgesehen, in welchen Zusammenhängen die Lemmata »Project« und »Projectenmacher« überhaupt vorkommen. Zum anderen wird anhand der Lebensgeschichte des Johann Heinrich Gottlob von Justi (1717-1771) überlegt, was die Existenz dieses Kameralisten auszeichnete, der nicht nur sich selbst, sondern jeden bewusst planenden Menschen zum Projektemacher erklärte. Die lexikalischen und biographischen Befunde sollen abschließend aufeinander bezogen und im Lichte der fragilen Ökonomie und der Struktur des Fürstenstaats im 17./18. Jahrhundert gedeutet werden.

\section{"Projectenmacher $"$ IN ZWei Enzyklopädien DES 18. JAHRHUNDERTS}

Glaubt man den Haupteinträgen zu Projektemachern in den Enzyklopädien von Zedler und Krünitz, dann handelte es sich um unseriöse Personen, die es darauf anlegten, Anleger um ihr Kapital zu prellen und gutgläubige Fürsten zu betrügen. Der Artikel »Projectenmacher« im Universal-Lexicon des Johann Heinrich Zedler ${ }^{5}$ aus dem Jahr 1741 beginnt folgendermaßen:

Projectenmacher, heissen insgemein diejenigen, welche den Leuten dieses oder jenes Project, davon sie sich vor die Erfinder ausgeben, entdecken, und sie zu deren Ausführung unter scheinbahren Vorstellungen eines daraus zu erwartenden grossen Gewinnstes anermuntern. Einem solchen muß man nicht sogleich Gehör

3 | So der Titel des Beitrags von Höge (2008).

4 | Zur Praxis der Produktion von Enzyklopädien und zur Wissensordnung im 18. Jahrhunderts vgl. Schneider/ZedImaier (2004); Schneider (2006); Schneider (2012).

5 | Zur Entstehung und zum Produktionsprozess von Zedlers Universal-Lexicon siehe Lohsträter/Schock (2013). 
geben, weil sie insgemein Betrüger sind, vielweniger Geld=Summen seinen hochherausgestrichenen Vorschlag damit auszuführen, geben, denn das und nichts anders ist es öffters, was solche Leute intendiren. ${ }^{6}$

Solche unseriösen Personen hatten es offenbar besonders auf Fürsten abgesehen:

Solche Projectmacher wagen sich öffters an hohe Häupter, und hat ein Minister hiebey alle Behutsamkeit anzuwenden, daß er erforsche, ob sein Landes-Herr mit einem ehrlichen Mann oder einem Betrüger zu thun habe, welches letztere sich sonderlich erfahren und mercken läßt, wenn ein solcher Kerl von lauter grossen Stücken und viel tausenden spricht, Monopolia angiebt und darbey grosse Besoldungen und Praedicata sich ausbedingen will, ingleichen wann er mehr des Herrn seine Schatzkammer als dessen Unterthanen zu bereichern, im Vorschlage hat, da doch, wenn diese viel haben, des Landes-Herrn seine Kammer auch keinen Mangel leiden wird. Man erkennet ferner solche Leute, wenn sie großen Vorschuß voraus prätendiren, und tausend haben wollen, wozu sie hundert nöthig hätten [...]. ${ }^{7}$

Analysiert man diesen dichten Eintrag genauer, werden erste Ambivalenzen erkennbar. Offenbar gab es ausnahmsweise doch ehrliche Leute, die mit Projekten an Fürsten herantraten. Regierungskunst bestand nun darin, Betrüger von Ehrenmännern zu unterscheiden und hierzu werden auch erste Kriterien aufgeführt. Als unschwer erkennbarer Subtext schwingt mit, dass es oftmals der behutsamen Vorsicht nüchterner Berater bedurfte, um Fürsten von Torheiten abzuhalten. Ein habsüchtiger Fürst konnte durch einen gewieften Projektemacher leicht zum betrogenen Betrüger werden. Darin schwingt allgemeine Hofkritik ${ }^{8}$ mit: Wie konnte verhindert werden, dass Fürsten falsche Berater wählten, mit der Folge, dass diese ihr eigensüchtiges Privatinteresse über das Gemeinwohl stellten? Möglicherweise erwies sich der Minister als falscher Freund des Fürsten, machte mit dem betrügerischen Projektemacher gemeinsame Sache, um Fürst und Kammer, Land und Leute auszuplündern. ${ }^{9}$ Schließlich verdeutlicht der Eintrag, dass es Projektemachern nicht allein darum

6 | Zedler: Universal-Lexicon, Bd. 29, 784.

7 | Ebd.

8 | Kiesel (1979).

9 | Martens (1996), Luttenberger (2001), 481, 484. 
ging, Belohnungen und Vorschüsse einzuheimsen, sondern auch Monopole für die Produktion oder den Vertrieb von bestimmten Gütern zu erhalten. Die Vergabe solcher Privilegien war weit verbreitet und wurde europaweit von den Staaten genutzt, um steuernd in das Wirtschaftsgeschehen einzugreifen. Die liberale Fundamentalkritik eines Adam Smith war zwar noch nicht formuliert, gleichwohl gab es auch vorher schon eine lebhafte Kontroverse über Sinn und Unsinn von Steuerbefreiungen, Handels- und Produktionsmonopolen. ${ }^{10}$

In der ersten Hälfte des 18. Jahrhunderts überwogen demnach pejorative Bedeutungen von »Projektemacher«. Dieser semantische Haushalt scheint stabil gewesen zu sein, denn siebzig Jahre später, im Jahre 1811, meldet die Oekonomische Encyklopädie des Johann Georg Krünitz kurz und bündig: »Projectenmacher, ein Mann, der allerley Anschläge macht, vorzüglich in nachtheiligem Verstande, der sich mit unhaltbaren Entwürfen beschäftigt, und diese andern aufzudringen sucht.«11

Folgt man den beiden Lexikoneinträgen von 1741 und 1811, dann ging es Projektemachern - jedenfalls im deutschen Kontext - nicht so sehr darum, privates Kapital für ihre Vorhaben aufzutreiben, sondern Prämien für ihre Vorhaben zu bekommen bzw. ökonomisch motivierte Maßnahmen der Fürstenstaaten anzuregen, um Monopole zu erhalten, die geeignet waren, Gewinne aus Handel oder Produktion möglichst in die eigene Tasche zu lenken. Dann stellt sich freilich die Frage, warum Fürsten und Staatsverwaltungen überhaupt auf Projekte eingehen sollten, wenn sie entweder unhaltbare Hirngespinste waren, oder nur scheinbar Gewinn abwarfen, oder - schlimmer noch - in betrügerischer Absicht vorgeschlagen wurden. Mit einem Wort, hinter der Projektemacherei muss sich mehr verbergen als Lug und Trug.

Wenn man im Krünitz nach dem Wort Project und seinen Komposita weiter recherchiert, erhält man die beeindruckende Menge von 352 Einträgen. Damit lässt sich ein semantisches Feld abstecken, auf dem man den Projektemacher präziser verorten kann. Man erhält einen facettenreichen Befund, in dem Ambivalenzen und Widersprüche nicht aufgelöst, sondern in verschiedene Richtungen konturiert werden können. Zum einen wird Project etymologisch mit Projection in Verbindung gebracht, wodurch dem Begriff mathematische und kartographische Bedeutungs-

10 | Priddat (1998), 17-48; Magnusson (1994); Isenmann (2014).

11 | Krünitz: Oeconomische Encyclopädie, Bd. 117, 720. 
gehalte zuwachsen. ${ }^{12}$ Diese Lemmata verweisen auf eine Metaphorik kalkulierender Berechnung, die Projekte offenbar auszeichnete. Das ist noch wenig überraschend, erstaunlicher sind einige Verwendungsweisen, die den Lemmata Project/Projectemacher zusätzliche Bedeutungstiefe geben, so im Artikel »Frauen=Zimmer«:

So viel ist gewiß, es ist eine fast allgemein gewordene Meinung, daß wir Mannspersonen durch den freyen Umgang, der uns mit Frauenzimmern gestattet worden, sehr viel gewonnen haben sollen. Ein gewisser engländischer Schriftsteller glaubt, daß die großen Revolutionen in seiner Nation, die vielen Rebellionen und Empörungen, und die innen sonst so gewöhnlich gewesenen blutdürstigen Anschläge und Projecte, bloß dadurch nicht mehr so öftere Erscheinungen seyn, weil der Geist der Mannspersonen durch den Umgang mit dem Frauenzimmer überhaupt feiner und sanfter geworden, weil man in ihrer Gesellschaft nicht mehr so viel Gelegenheit gefunden habe, sich beständig mit Staatsangelegenheiten und Anschlägen zu Stiftung neuer Factionen zu unterhalten, weil man an ihren Scherzen und Vergnügungen mehr Antheil nehmen müssen, als sonst, und weil durch ihre natürliche Furchtsamkeit und Gutherzigkeit manches verhindert worden, welches Mannspersonen allein, ohne Verbindung mit Frauenzimmern, gewiß würden ausgeführt haben. ${ }^{13}$

Wir haben hier einen gendered discourse vor uns, in dem Frauen die zivilisierende Kraft verkörpern, während Männer zu politischer Unruhe neigen, zu Verschwörungen, Rebellionen, Aufständen und Bürgerkriegen, die auf Projektemacherei zurückgehen. ${ }^{14}$ Es sei betont, dass es sich bei solchen politischen Machinationen um ein überschaubares semantisches Nebenfeld handelt. Die Mehrzahl der Einträge widmet sich dagegen Projecten, die im Schnittfeld von Staatlichkeit, guter Policey und Wirtschaftspolitik angesiedelt sind. So vermerkt der Artikel »Kitzel«:

Wenn von Sachen die Rede ist, als: von Affairen, Unternehmungen, Projecten etc. so bedeutet im figürlichen Sinne kitzelig so viel als bedenklich, gefährlich, mißlich, und dergleichen. Wer öffentliche Gelder unter Händen (oder unter seiner Ver-

12 | Ebd.

13 | Krünitz: Oeconomische Encyclopädie, Bd. 14, 258.

14 | Zu den gendered dicourses in geselligen Kontexten vgl. Opitz/Kleinau/Weckel (2000) und Weckel/0pitz/Hochstrasser/Tolkemitt (1998). 
waltung) hat, bekleidet einen kitzeligen, das ist gefährlichen Posten. Dieß ist eine kitzlige (mißliche) Unternehmung; sie erfordert ausnehmend viel Behutsamkeit. Dieß ist ein kitzliges (bedenkliches) Project; dieser Entwurf ist schwer (oder gefährlich) auszuführen; er ist tausend Schwierigkeiten und Anstößen unterworfen; der Zweck kann gar leicht dabey verfehlt werden etc. ${ }^{15}$

Danach sind Projekte riskante Unternehmen. Und die Verwaltung öffentlicher Gelder gehört offenbar zu diesen Projekten voller Risiken. Das lässt aufhorchen. Im unverdächtigen Artikel »Forst=Nutzungs=Etat« lesen wir: »Die Anfertigung oder Projectirung des Forstetats ist eigentlich ein Geschäft des Oberforstmeisters. ${ }^{16}$ Die bloße Aufstellung einer KostenNutzen-Rechnung ist demnach bereits ein Projekt. Schließlich eine Passage aus dem Artikel »Kammer=Ordnung«:

Die Verfertigung einer Kammerordnung, zumahl aber einer allgemeinen Kammer= und Finanz=0rdnung, ist gar keine leichte Sache ... Das Hauptwerk dabey kommt darauf an, daß die Kammerordnung auf die Natur der Sache, auf den wahren Zusammenhang des Finanzwesens, und auf vernünftige Haushaltungs= und Regierungs=Regeln gegründet werde. Gemeiniglich lässet der Regent das erste Project dazu durch einen geschickten und erfahrnen Kammeralisten verfertigen, welcher nicht allein den ganzen Zusammenhang der innern Landeswirthschaft zu übersehen im Stande ist, sondern auch in dem Zustande des Landes und seiner Verfassungen sowohl, als auch in der bisherigen Einrichtung des Kammeralwesens, hinlängliche Kenntniß und Erfahrung besitzt. Dieses erste Project geht der Landes=Herr mit einigen vertrauten Finanz= Ministern oder geh. Finanz=Räthen, durch; und nachdem ihre Erinnerungen dabey bemerkt sind, lässet der Regent sodann ein ausführliches Project verfertigen $[\ldots]^{17}$

Die Planung eines Gesetzentwurfes in Cameralia fällt demnach ebenfalls unter die Projekte. Projektemacherei ist also eine genuine Aufgabe jeder Staatsverwaltung. Wissenschaftlich gebildete Kameralisten gelten offenbar als besonders geeignete Fachleute für diese Aufgabe. Man ist dabei jedoch auch für Vorschläge von Personen ohne Staatsamt offen. Im Artikel »Kriegs=Collegium« ist wie häufig bei Krünitz ein preußischer

15 | Krünitz: Oeconomische Encyclopädie, Bd. 39, 289.

16 | Krünitz: Oeconomische Encyclopädie, Bd. 14, 617.

17 | Krünitz: Oeconomische Encyclopädie, Bd. 33, 397. 
Gesetzestext inseriert, nämlich die »Instruction und Reglement für das Ober=Kriegs=Collegium v.J. $1788 \ll$. Darin heißt es über die Aufgaben einer Abteilung der Heeresverwaltung:

Was die, zur Erleichterung der Geschäfte überhaupt, besonders zur Prüfung eingegebener Projecte und angebothener neuen Erfindungen, bey der Artillerie verordnete Commission betrifft, so bestätigen Se. Kön. Maj. solche hiermit in so fern, daß solche verpflichtet seyn soll, in den erforderlichen Fällen, ihre genommene Beschlüsse dem Ober=Kriegs= Collegio unverweigert zur Prüfung und weitern Entscheidung vorzulegen. ${ }^{18}$

Es wird demnach ein eigenes behördliches Verfahren normiert, das dazu dient, Projekte, die von Außenstehenden an die preußische Artillerie herangetragen werden, durch eine auf Dauer gestellte Kommission auf ihre Nützlichkeit zu prüfen, und die gewonnenen Einschätzungen in die militärische Hierarchie einzuspeisen. Zum Abschluss ein letztes Beispiel, der Artikel »Handel (Frankreich)«:

Ludwig hinterließ den Nahmen des Großen, indem seine Länder von der Erwerbung derselben schmachteten. Während der Regentschaft suchte man dem Lande und dem Handel wieder aufzuhelfen; allein die Mittel, welche ergriffen wurden, vergrößerten den Schaden. Der berühmte Lau erschien mit einem Project von dem weitesten Umfange. Scharfsinn, Erfahrungen und richtige Urtheile über den Credit, und seine möglichste Ausdehnung waren darin vereinigt. Hätte man es mit Mäßigung genutzt, so wäre es ein heilsames Hülfs=Mittel geblieben; allein man übertrieb es, und es wurde zum Gift der ganzen Nation. ${ }^{19}$

Hier wird auf einen der berühmtesten Projektemacher des 18. Jahrhunderts angespielt, den Schotten John Law, der in der Spätphase der Herrschaft Ludwigs XIV. erstmals an den französischen Hof mit seiner Idee herantrat, Papiergeld einzuführen und dadurch mit einem Schlag die ungeheure Staatsverschuldung aus der Welt zu schaffen, Handelshindernisse zu beseitigen und die französische Wirtschaft anzukurbeln. Während der Vormundschaftsregierung des Herzogs Philippe von Orléans zwischen 1715 und 1723 erhielt er die Chance, diese Idee zu realisieren.

18 | Krünitz: Oeconomische Encyclopädie, Bd. 50, 109.

19 | Krünitz: Oeconomische Encyclopädie, Bd. 21, 626-627. 
Nach anfänglichen Erfolgen scheiterte sein nach heutigem Verständnis einleuchtendes Projekt einerseits am mangelnden Realismus des Hofes, der auf unbegrenzte Geldvermehrung zur Realisierung aller möglichen Prestigevorhaben setzte, andererseits an den Spekulationsgeschäften von Privatleuten, die zu einer Überbewertung der Aktien der französischen Kolonialgesellschaft in Louisiana und zu anschließenden Panikverkäufen führten. ${ }^{20}$ Das Lawsche Projekt wies bereits die wesentlichen Merkmale der heutigen monetären Ordnung auf: Der Wert des Geldes beruhte nicht auf seinem inhärenten Materialwert, wie bei Gold- und Silberwährungen, sondern auf dem Vertrauen der Marktteilnehmer, dass die Geldmenge in einem ausgewogenen Verhältnis zur Wertschöpfung der betreffenden Nationalökonomie stehen möge. Diese rationale Geldmarktordnung beruht freilich auf der Magie des Geldes und ist zugleich ständig von ihr bedroht, zum einen durch eine unverantwortliche Geldmarktpolitik der Notenbanken, zum anderen durch die Hoffnung auf raschen, arbeitsfreien Gewinn und durch die Angst davor, das Gewonnene mit einem Schlag wieder $\mathrm{zu}$ verlieren. ${ }^{21}$

Interessanterweise wird John Law von dem Autor des Lexikon-Artikels abwägend beurteilt und nicht verdammt, obwohl bekannt war, dass er nicht nur ein kluger ökonomischer Kopf, sondern auch ein notorischer Spieler war, was ihn in den Augen der meisten aufgeklärten Zeitgenossen moralisch diskreditierte.

Was kann man aufgrund der Einträge in den beiden Lexika über das zeitgenössische Verständnis von »Projekt« und »Projektemacher« sagen? Als Projekte gelten ganz allgemein Pläne, die aufgrund rationaler Überlegung, manchmal auch aufgrund kalkulierender Berechnung in die gesellschaftliche Ordnung eingreifen. Diese Eingriffe bezwecken eine Verbesserung dieser Ordnung, bisweilen in einem sehr allgemeinen Sinne, meist viel bescheidener, in irgendeinem technischen, ökonomischen oder administrativen Detail. Entsprechend können solche Entwürfe neue Technologien, eine innovative Geschäftsidee oder eine Reform staatlicher Einrichtungen betreffen. In den Handelsnationen Westeuropas treten Projektemacher vor allem mit merkantilen Vorhaben hervor, im deutsch-

20 | Murphy (2002).

21 | Vgl. hierzu die Ausführungen zum schottischen Projektemacher William Paterson, erfolgreicher Gründer der Bank of England (1694), dessen Kolonialprojekt fulminant scheiterte, im Beitrag von Claudia Claridge in diesem Band. 
sprachigen Bereich ist der Projektemacher in erster Linie eine soziale Gestalt, die Vorschläge an den Fürsten, seinen Hof, seine Regierung und Verwaltung heranträgt. Hier wie dort stehen Projektemacher im Verdacht der Phantasterei und der Unredlichkeit. Allerdings sollte deutlich geworden sein, dass keinerlei Eindeutigkeit im Wortgebrauch besteht, sondern dass dieser von strukturellen Ambivalenzen geprägt ist.

Mit der Kameralwissenschaft entstand sogar eine akademische Disziplin, zu deren Kernaufgaben die Projektemacherei gehörte. ${ }^{22}$ Denn der Kameralwissenschaft ging es um die Einführung innovativer Technologien und die Perfektionierung der Staatsökonomie, oder wie die Zeitgenossen es formulierten um die Verbesserung der guten Policey unter dem Leitbild der Glückseligkeit der Staaten. ${ }^{23}$ Das Kameralfach bildete ein Phänomen im höheren Bildungssystem des Alten Reiches und einiger seiner Nachbarländer, namentlich der Habsburgermonarchie und Skandinaviens. Dagegen gab es keine entsprechende akademische Tradition in Großbritannien und in Frankreich.

\section{Der Kameralist und Projektemacher Johann Heinrich Gottlob von Justi}

In welcher Weise Projektemacherei und Kameralismus ineinandergriffen, lässt sich exemplarisch am Lebensweg von Johann Heinrich Gottlob Justi verdeutlichen. ${ }^{24}$ Justi war einer der bedeutendsten Kameralisten des 18. Jahrhunderts, literarisch ungemein produktiv, ein energiegeladener Pläneschmied, dessen soziale Stellung stets prekär blieb und der zuletzt tragisch scheiterte. Geboren wurde Justi 1717 in Sangershausen bei Halle an der Saale als Sohn des Hofbeamten Georg Heinrich Justi, der 1720 verstarb. Seine Schulbildung am Gymnasium in Quedlinburg wurde von seinem Stiefvater finanziert. Als Zwanzigjähriger nahm er als Privatsekretär

22 | Instruktiv dazu Bauer (1997), 206-217, von dem die Konzeption des Kameralisten als Projektemachers übernommen wurde.

23 | Zur Grundlegung dieser Begrifflichkeit bei Justi vgl. Sandl (1997), 45-72. Zur Rolle Justis und des Herausgebers und Kommentators der "Grundsätze der Policeywissenschaft", Johann Beckmann, vgl. Priddat (1998), 17-48.

24 | Zur Biographie siehe Frensdorff (1903). Auf dessen Ergebnissen beruhen Tribe (1987) und Reinert (2009) sowie Bauer (1997), 214-215. 
des Oberstleutnant Wigand Gottlob von Gersdorff in sächsischen Diensten am Österreichischen Erbfolgekrieg teil. Gersdorff erkannte das Talent des jungen Mannes und finanzierte ein Jurastudium, das Justi 1742 an die Universität Wittenberg führte. ${ }^{25}$ Dort wurde er 1744 im Alter von 27 Jahren mit einer Dissertation über die Bestrafung der Desertion promoviert ${ }^{26}$ und kehrte anschließend in den Dienst der sächsischen Armee zurück. Sein Patron Gersdorff fiel 1745 in der Schlacht von Hohenfriedberg. Justi quittierte daraufhin den sächsischen Dienst. Im Jahr 1746 sehen wir ihn in Dresden als Herausgeber einer moralischen Wochenschrift mit dem Titel Ergetzungen der vernünftigen Seele aus der Sittenlehre und der Gelehrsamkeit überhaupt. Im selben Jahr heiratete er die Pfarrerstochter Gertrud Feliciana Johanna Pietsch. In Dresden hielt es den jungen Mann jedoch nicht lange. 1747 kehrte er in seine Vaterstadt Sangershausen zurück, wo er als Rat am Hof der verwitweten Herzogin von Sachsen-Eisenach tätig war. In den folgenden drei Jahren verfasste Justi vor allem Schriften zur Metaphysik ${ }^{27}$. Eine neuerliche Wende nahm sein Leben im Jahre 1750. Der nun 33jährige siedelte nach Wien über, wo er chemische Experimente mit Pflanzenfarbstoffen unternahm, die das teure Indigo ersetzen sollten. Es erscheinen erste Publikationen zur Kameralistik, systematisch vorgehende, kurz gefasste Lehrbücher. ${ }^{28}$ Noch im selben Jahr erhielt er eine Anstellung als Professor für Rhetorik und deutsche Sprache am berühmten Theresianum, der kurz zuvor von Maria Theresia gegründeten Ritterakademie. Nach zwei Jahren, 1752, erfolgte Justis Ernennung zum Professor für Praxis im Cameral-, Commercial- und Bergwesen. Er propagierte mit einigem Erfolg die Ausbeutung einer Silbermine im niederösterreichischen Annaberg, wodurch er den Ruf eines Montanfachmanns begründete. Aber bereits im Folgejahr 1753 verließ er die Habsburgischen Dienste aus nicht völlig geklärten Gründen. Die Spekulationen reichen

25 | Frensdorff (1903), 360-366.

26 | Justi: Dissertatio luridica de Fuga Militiae.

27 | Erverfasste 1747 eine preisgekrönte Schrift zum Monadenstreit, die auf eine Aufgabe der Berliner Akademie der Wissenschaften zurückging. Die Schrift wurde hart kritisiert, was Justi zu zahlreichen Verteidigungsschriften veranlasste. Siehe dazu Frensdorff (1903), 371-375.

28 | Justi (1756); Justi (1758): Staatswirthschaft; Justi (1759): Grundriß. Zur Einschätzung dieser Werke im Rahmen des Kameralismus und der zeitgenössischen Ökonomie siehe Schefold/Rieter (1993). 
vom Scheitern seiner Pläne für den weiteren Ausbau der Silberminen, über einen Konflikt des Protestanten Justi mit den Jesuiten bis hin zu gesundheitlichen Gründen: Angeblich vertrug er die Wiener Luft nicht. ${ }^{29}$

Er ging nach Mansfeld, wo er die von ihm gegründete Zeitschrift Neue Wahrheiten zum Vorteil der Naturkunde und des Gesellschaftlichen Lebens der Menschen herausgab. Wie bei seinen anderen Zeitschriftenprojekten stammte ein Großteil der Artikel aus eigener Feder. 1755 erfolgte ein erneuter Umzug, diesmal nach Leipzig. Dort erschien sein Werk Entdeckte Ursachen des verderbten Münzwesen Deutschlands. Wenige Monate später siedelte er nach Göttingen über, wo er in der kurhannoverschen Bergverwaltung angestellt wurde und an der Universität Vorlesungen zur Ökonomie hielt. Aber auch an der angesehenen Universität Göttingen fasste er nicht dauerhaft Fuß. Nach der Scheidung von seiner ersten Ehefrau Gertrud im Jahre 1756, die als Abfindung seine Bibliothek erhielt, zog er 1757 nach Dänemark weiter. ${ }^{30}$ Die Kinder aus dieser Ehe folgten dem Vater auf seinem unsteten Lebensweg. In Kopenhagen sollte er im Auftrag der dänischen Krone das Bergwesen in Norwegen und die Landwirtschaft in Jütland reformieren. Justi nahm nachhaltigen Einfluss auf die gerade entstehende dänische Kameralwissenschaft. ${ }^{31}$

Nach nur einem Jahr in Kopenhagen ging Justi 1758 ins dänische Altona, wo seine politische Schrift Die Chimäre des Gleichgewichts von Europa erschien, ein Jahr später gefolgt von Die Chimäre des Gleichgewichts der Handlung und Schiffahrt. Während des Siebenjährigen Kriegs wirkte Justi als politischer Autor auf preußischer Seite. Er behauptete, ein Komplott der Jesuiten entdeckt zu haben, die einen riesigen Schatz angehäuft hätten, um Protestanten zur Konversion zu verleiten. ${ }^{32}$ Als er 1760 die Kriegsführung der russischen Zarin Elisabeth und Maria Theresias öffentlich als »von bis hierhin unbekannter Grausamkeit« ${ }^{33}$ kritisierte, musste er Dänemark verlassen. Auf den Protest des österreichischen Botschafters am dänischen Hof wurden seine Schriften in Altona vom Henker öffentlich verbrannt. Daraufhin erfolgte der Umzug nach Berlin und der Eintritt in preußische Dienste. Justi nahm dort seine chemischen Experi-

29 | Frensdorff (1903), 375-391.

30 | Frensdorff (1903), 391-412.

31 | Frensdorff (1903), 412-435.

32 | Frensdorff (1903), 401-410, 433.

33 | Frensdorff (1903), 437-438. 
mente wieder auf und arbeitete bevorzugt im Bereich der angewandten Naturwissenschaften. 1761 erschien sein kameralistisches Hauptwerk Die Grundfeste zu der Macht und Glückseeligkeit der Staaten; oder ausführliche Vorstellung der gesamten Policey-Wissenschaft in zwei Bänden, das im 18. Jahrhundert mehrere Auflagen erlebte. Von 1762 bis $176_{5}$ übersetzte der Rastlose die ersten vier von zuletzt 21 Teilen der Descriptions des Arts et Métiers. ${ }^{34}$ Dieses von der französischen Akademie der Wissenschaften herausgegebene Werk, das in Paris zwischen 1761 und 1788 in 116 FolioBänden erschienen ist, bietet präzise Texte und bildliche Darstellungen zum zeitgenössischen Handwerk und zur großgewerblichen Technologie.

Wegen der hohen Lebenshaltungskosten in Berlin zog Justi nach Bernau um und erwarb kleineren Grundbesitz in der Nähe von Soldin. Er erhielt eine königliche Pension von 200 Talern. Die Anzeichen mehrten sich, dass Justi in Preußen heimisch werden wollte. Im Jahr 1765 ernannte Friedrich II. ihn zum Berghauptmann in Landsberg an der Warthe, eine Stellung, die mit einem Jahresgehalt von 2.000 Talern sehr gut dotiert war. Justi begann dort mit der Produktion von Blechen. Zwei Jahre später unterbreitete er dem von ihm bewunderten König das Projekt für eine Blechproduktion in großem Stile, die binnen Kurzem den gesamten Bedarf in Preußen decken sollte. Er überzeugte den Monarchen von diesem Vorhaben, der ausländische Produkte zum Schutz der neuen einheimischen Herstellung mit einem Einfuhrzoll in Höhe von 30 \% belegte. Die Blechherstellung in Landsberg blieb jedoch weit hinter den Erwartungen zurück. Seit 1767 wurde eine Kommission der Kriegs- und Domänenverwaltung tätig, die zahlreiche Vorwürfe gegen Justi untersuchte. 1768 verurteilten ihn die preußischen Gerichte zur Rückzahlung von 2.878 Talern Subventionen an die Staatskasse. In seiner Ehre gekränkt kritisierte Justi die preußischen Behörden öffentlich, was vom König zunächst mit Hausarrest, schließlich mit Festungshaft geahndet wurde. ${ }^{35}$ Auch in Haft setzte er seine rastlose Publikationstätigkeit fort, es erschienen unter anderen seine Chymische Schriften. Am 21. Juli 1771 starb Justi im Alter von

34 | Die deutsche Übersetzung trägt den Titel Schauplatz der Künste und Handwerke. Die berühmten Bildtafeln der Encyclopédie von Diderot und d'Alembert waren übrigens in vielen Fällen Raubkopien der Kupfer aus den Descriptions des Arts et Métiers. Vgl. dazu Huard (1951).

35 | ZurTätigkeit Justis in preußischen Diensten vgl. Frensdorff (1903), 435-459. 
54 Jahren in der Festungshaft in Küstrin. Zu seinen Lebzeiten erschienen 67 Monographien, zahlreiche Zeitschriften und acht Übersetzungen. ${ }^{36}$

Er gehörte damit zu den produktivsten Autoren des schreibfreudigen 18. Jahrhunderts. Justi war dabei wahrlich nicht immer originell, aber stets scharfsinnig und reflexiv. Er ging keinem Streit aus dem Weg. Plagiate waren selten, offen eingestandene Variationen und Wiederholungen des von ihm selbst Geschriebenen dagegen die Regel. Vor Justi war kaum ein Thema sicher. Angesichts seiner eigenen Existenz nimmt es nicht wunder, dass er auch über den Projektemacher öffentlich räsonierte. $176_{1}$ veröffentlichte er eine kleine Abhandlung, ${ }^{37}$ in der er alle Menschen, die ihr irdisches Schicksal aktiv planend in die eigene Hand nehmen, als Projektemacher charakterisierte:

Alle Menschen sind Projectmacher. ... Meines Erachtens versteht man unter einem Project, einen ausführlichen Entwurf eines gewissen Unternehmens, wodurch unsere eigene oder anderer Menschen zeitliche Glückseligkeit befördert werden soll; zu welchem Ende alle zu ergreifende Mittel und Maaßregeln, benebst den zu befürchtenden Schwierigkeiten und Hindernissen und die Art und Weise dieselben aus dem Wege zu räumen, in einem solchen Entwurfe deutlich vorgestellet werden. Nach diesem Begriffe glaube ich nicht, daß eben jemand böse werden wird, wenn man ihn mit dem Ehrennamen eines Projectmachers belegt. Denn wir alle wollen unsere zeitliche Glückseligkeit befördern; wir alle laßen uns zu dem Ende in verschiedene Unternehmungen ein; und wir alle machen über die zu diesem Endzwecke zu ergreifende Mittel und Maaßregeln, und über die Schwierigkeiten die sich etwan ereignen möchten, Ueberlegungen: Wir entschließen uns darüber und machen mithin über unsere Unternehmungen ausführliche Entwürfe. ${ }^{38}$

Es gebe zwar viele Menschen, die in den Tag hinein lebten oder die bei ihren Planungen die notwendige vernünftige Voraussicht vermissen ließen, allein, man solle in der Jugend einen Lebensentwurf entwerfen. Dabei müsse man seine Talente und Fähigkeiten in Rechnung stellen, da sie die Grundlage weltlichen Erfolgs seien. »Schmeichlerische Einbildung« der Eigenliebe müsse man »so viel möglich im Zaume« halten. ${ }^{39}$ Ein

36 | Die vollständigste Bibliographie bei Reinert/Reinert (2009).

37 | Justi (1761): Gedanken.

38 | Ebd., 257.

39 | Ebd., 259. 
solch planvolles Vorgehen sei freilich eher die Ausnahme als die Regel, weil Selbstliebe und Bequemlichkeit dem entgegenstünden. Grundsätzlich unterstellte Justi, dass Probleme durch gedankliche Einbeziehung aller obwaltenden Umstände zu überwinden seien. Optimistisch ging er davon aus, dass man Kontingenz durch möglichst umfassende Information und durch logische Überlegung zu einer Restgröße reduzieren könne, die zu vernachlässigen sei. Das gesamte Leben erschien ihm als ein rational planbares Projekt.

Justi räumte ein, dass seine Definition von Projectemacherei nicht die übliche sei: »so ist es doch gewöhnlicher sich dieses Namens zu bedienen, wenn man solche Vorschläge und Entwürfe macht, die auf neue Anstalten und Maaßregeln in der Regierung der Staaten abzielen, und dadurch das wahre Interesse der Regenten und die Wohlfahrt der Republik mehr zu befördern. $\aleph^{40}$ Er jedoch ging weit darüber hinaus: »In diesem Verstande sollte nicht allein der Regent, sondern auch vornehmlich die obersten Staatsbedienten Projectmacher seyn. ${ }^{41}$ Es sei die vornehmste Pflicht des Fürsten und seiner Beamten, alle Maßnahmen zu ergreifen, die der Wohlfahrt der Länder und ihrer Bewohner dienten. Ein Konflikt zwischen den Interessen des Fürsten und denjenigen seiner Untertanen scheint in dieser Argumentation nirgends auf.

Man hat demzufolge im Werk Justis ein Musterbeispiel für den Eudämonismus der Aufklärung vor sich. Das 19. und 20. Jahrhundert sind nicht müde geworden, diese verbreitete Haltung der Naivität, der Überheblichkeit und der Gottverlassenheit zu zeihen. Das trifft den Kern der Argumentation von Justi jedoch nicht. Indem er sich als Projektemacher in eine Phalanx mit den aufgeklärten Fürsten und ihren leitenden Staatsbeamten stellt, spricht er seinem eigenen Tun sogar fürstlichen Rang zu. Angesichts dieser Hybris, war sein Fall tief.

40 | Ebd., 260.

41 | Ebd., 261. 


\section{Die Figur des Projektemachers innerhalb der POLITISCHen ÖKONOMIE der Frühen NeUzeit}

Was kann man aus dieser Lebensgeschichte lernen? Ökonomie und Politik waren im frühneuzeitlichen Fürstenstaat keine ausdifferenzierten Systeme. Die später von liberalen Denkern viel gescholtenen Spielarten ökonomischen Denkens des 17./18. Jahrhunderts können jedoch durchaus als angemessen bezeichnet werden, wenn sie einen unmittelbaren Zusammenhang zwischen politischem und wirtschaftlichem Handeln behaupteten. ${ }^{42}$ Die Ökonomie galt in hohem Maße als abhängig von der Gestaltung des politischen Umfelds, gleichzeitig waren sich die politisch Handelnden an den Höfen und in den Staatsverwaltungen bewusst, dass ohne wirtschaftliche Erfolge die eigene innen- und außenpolitischen Lage nicht zu verbessern war. Allgemein wurden ökonomische Akteure als »Humankapital« der Fürsten betrachtet, das man einsetzen konnte, um politische und militärische Gewinne einzuheimsen. Ging man - wie im Rahmen der merkantilistischen Doktrin üblich - davon aus, dass Ökonomie ein Nullsummenspiel bildete, dass also des einen Gewinn, notwendig des anderen Verlust bedeutete, war dem Wirtschaftskrieg aller gegen alle gedanklich der Boden bereitet. Das war zwar in der Zuspitzung unzutreffend, denn es bestanden durchaus Chancen auf ökonomisches Wachstum. Gleichwohl enthält es insofern einen wahren Kern, als die Wirtschaft des europäischen Weltsystems im 17./18. Jahrhundert als eine zutiefst kriegerische Ökonomie beschrieben werden kann. Mit bescheidenem Einsatz und bescheidenem Ehrgeiz konnte ein ehrbarer Kaufmann auch nur bescheidene Gewinne erzielen. Diese bescheidenen Gewinne waren auch noch durch nicht beeinflussbare politische und vor allem kriegerische Ereignisse stets gefährdet. Fulminante ökonomische Erfolge und ebenso große Misserfolge waren direkt mit dem militärischen Aufstieg und Fall von Staaten verbunden. Nirgends waren in so kurzer Zeit so große Gewinne zu erzielen wie auf dem Feld der Staatsfinanzierung, der Heeresversorgung und des Flottenbaus. ${ }^{43}$ Damit einher gingen allerdings nur schwer kalkulierbare Risiken durch Staatsbankrotte, verlorene Kriege und gesunkene Flotten. Aus der zutiefst unbefriedigenden gedanklichen Situation, in die man sich durch wirtschaftliches Nullsummendenken

42 | Burkhardt (1990); Stapelfeldt (2006), 36-51.

43 | Reinert (1999). 
und Staatsmonopolkapitalismus gebracht hatte, wiesen selbsternannte Fachleute Auswege - auch schon vor dem Aufkommen des ökonomischen Liberalismus. Genau diese Fachleute wurden von den Zeitgenossen als Projektemacher bezeichnet. Ihre Expertise bestand darin, die Statik zu überwinden, einen Kniff zu finden, um verborgene Schätze zu entdecken, ungeahnte Gewinne zu erzielen und blockierte Energien freizusetzen. ${ }^{44}$ Wer bereit war, ihren Empfehlungen zu folgen, dem versprachen sie, das Außeralltägliche Realität werden zu lassen.

Entsprechend der ökonomischen Strukturen hielten sie sich bevorzugt in der Kontaktzone um die Höfe und Staatsbehörden auf. Manchmal gelang es ihnen, eine Anstellung im Fürstendienst zu ergattern. Oftmals mussten sie sich mit der prekären Position eines Bittstellers begnügen, der für seine Ideen eine Entlohnung erwartete. Das galt in der ständischen Welt als ausgesprochen unfein. Ehrgeizige Aufsteiger - und darum handelte es sich im Allgemeinen - wurden mit Misstrauen betrachtet, galten als unseriös, man konnte ihnen nicht recht trauen. Und doch war man auf sie angewiesen, sie bildeten sozusagen den der sozio-ökonomischen Sauerteig, denn sie waren es, die mit ihren Ideen aus der ökonomischen und militärischen Statik herauszuführen versprachen, was angesichts der Konkurrenz unter den aggressiv auftretenden europäischen Staaten geboten erschien. Die vielen, die scheiterten, galten den Zeitgenossen, und gelten auch heute noch als Projektemacher. Die wenigen, deren Projekte glückten, nennt man Staatsmann, Industriepionier, Gründergestalt. Wegen ihrer spezifischen sozio-ökonomischen Rolle sollte man die Projektemacher des 17./18. Jahrhunderts nicht einfach als rundum moderne Gestalten bezeichnen. Sie gehören zur ständischen Gesellschaft, auch wenn sie an deren Überwindung mitwirkten.

\section{QuelLen}

Justi, Johann Heinrich Gottlob (1744): Dissertatio Iuridica de Fuga Militiae, Augustinus a Leyser (Präses); Io. Henricus Gottlob Iusti Brucca-Thuringus (Resp.),Wittenberg.

Justi, Johann Heinrich Gottlob (1755): Entdeckte Ursachen des verderbten Münzwesens in Teutschland nach ihren ersten und wahren Quellen, wobey

44 | Tribe (1988); Tribe (1995). 
zugleich neue und wirksame Mittel dagegen vorgeschlagen werden, die ein jeder Reichsstand vor sich, ohne Mitwirkung des Reichs, und ohne Recesse mit seinem Mitständen, in Ausübung bringen kann, Leipzig: Breitkopf.

Justi, Johann Heinrich Gottlob (1756): Grundsätze der Policeywissenschaft in einen vernünftigen, auf den Endzweck der Policey gegründeten, Zusammenhange und zum Gebrauch academischer Vorlesungen abgefasset, Göttingen: Van den Hoeck (ND der 3. Aufl. Frankfurt a.M. 1969).

Justi, Johann Heinrich Gottlob (1758): Staatswirtschaft oder Systematische Abhandlung aller oekonomischen und Kameralwissenschaften, die zur Regierung eines Landes erfordert werden, 2 Bde., Leipzig: Breitkopf ${ }^{2} 1758$ (ND Aalen 1963).

Justi, Johann Heinrich Gottlob (1758): Die Chimäre des Gleichgewichts von Europa, eine Abhandlung worinnen die Nichtigkeit und Ungerechtigkeit dieses zeitherigen Lehrgebäudes der Staatskunst deutlich vor Augen geleget und dabey allenthalben neue und rührende Betrachtungen über die Ursachen der Kriege und dem wesentlichen Grunde, worauf die Macht eines Staats ankommt, beygebracht werden, Altona: Iversen.

Justi, Johann Heinrich Gottlob (1759): Die Chimäre des Gleichgewichts der Handlung und Schiffahrt, oder: Ungrund und Nichtigkeit einiger neuerlich geäußerten Meynungen von denen Maaßregeln der freyen Mächte gegen die zu befürchtende Herrschaft und Obermacht zur See, wobey zugleich neue und wichtige Betrachtungen über die Handlung und Schiffahrt der Völker, und über den Punct der daraus entstehenden Macht und Glückseligkeit beygebracht werden, Altona: Iversen.

Justi, Johann Heinrich Gottlob (1759): Der Grundriß einer Guten Regierung in Fünf Büchern verfasset, Frankfurth/Leipzig: Garbe.

Justi, Johann Heinrich Gottlob (1760/61): Die Grundfeste zu der Macht und Glückseeligkeit der Staaten oder ausführliche Vorstellung der gesamten Policey-Wissenschaft, 2 Bde., Königsberg/Leipzig: Woltersdorf (ND Aalen 1965).

Justi, Johann Heinrich Gottlob (1761-1764): Gesammlete Politische und Finanzschriften über wichtige Gegenstände der Staatskunst, der Kriegswissenschaften und das Cameral- und Finanzwesens, 3 Bde., Kopenhagen/ Leipzig: Rothensche Buchhandlung.

Justi, Johann Heinrich Gottlob (1761): »Gedanken von Projecten und Projectmachern«, in: ders.: Gesammlete Politische und Finanzschriften, Bd. 1, 256-281. 
Justi, Johann Heinrich Gottlob (1761): Gesammlete Chymische Schriften, worinnen das Wesen der Metalle und die wichtigsten chymischen Arbeiten vor dem Nahrungstand und das Bergwesen ausführlich abgehandelt werden, 2 Bde., Leipzig: Verlag des Buchladens der Realschule.

Krünitz, Johann Georg (Hg.) (1773-1858): Oeconomische Encyclopädie oder allgemeines System der Land-, Haus- und Staats-Wirthschaft. In alphabetischer Ordnung, 242 Bde., Berlin: Pauli (www.kruenitzı.uni-trier.de/).

Smith, Adam (1776): An Inquiry into the Nature and Causes of the Wealth of Nations, 2 Bde., London: W. Strahan \& T. Cadell.

Zedler, Johann Heinrich (Hg.) (1731-1754): Grosses Vollständiges UniversalLexicon aller Wissenschafften und Künste, 68 Bde., Halle/Leipzig: Zedler (www.zedler-lexikon.de/).

\section{FORSCHUNGSLITERATUR}

Bauer, Volker (1997): Hofökonomie. Der Diskurs über den Fürstenhof in Zeremonialwissenschaft, Hausväterliteratur und Kameralismus, Wien u.a.

Burkhardt, Johannes (1990): »Das Verhältnis von Ökonomie und Politik in der neuzeitlichen Institutionengeschichte«, in: Göhler, Gerhard/ Lenk, Kurt/Schmalz-Bruns, Rainer (Hg.): Die Rationalität politischer Institutionen. Interdisziplinäre Perspektiven, Baden-Baden, 169-187.

Frensdorff, Ferdinand (1903): »Über das Leben und die Schriften des Nationalökonomen J.H.G. von Justi«, in: Nachrichten der Königl. Gesellschaft der Wissenschaften zu Göttingen, Philologisch-historische Klasse, Heft 4 (ND: Glashütten im Taunus 1970).

Höge, Helmut (2008): »Der Projektemacher als postmodernes Massenphänomen. Wo er aufscheint und (möglicherweise) untergeht«, in: Krajewski, Markus (Hg.): Projektemacher. Zur Produktion von Wissen in der Vorform des Scheiterns, Berlin (3. Aufl.), 219-243.

Huard, Georges (1951): »Les planches de l'Encyclopédie et celles de la Description des Arts et Métiers de l'Académie des Sciences«, in: Revue d'histoire des sciences et de leurs applications, vol. 4, n 3-4, 238-249.

Isenmann, Moritz (Hg.) (2014): Merkantilismus. Wiederaufnahme einer Debatte, Stuttgart.

Kiesel, Helmuth (1979): »Bei Hof, bei Höllu. Untersuchungen zur literarischen Hofkritik von Sebastian Brant bis Friedrich Schiller, Berlin. 
Krajewski, Markus (Hg.) (2008): Projektemacher. Zur Produktion von Wissen in der Vorform des Scheiterns, Berlin (3. Aufl.).

Lohsträter, Kai/Schock, Flemming (Hg.) (2013): Die gesammelte Welt. Studien zu Zedlers Universal-Lexicon, Wiesbaden.

Luttenberger, Albrecht P. (2001): »Miseria vitae aulicae. Zur Funktion hofkritischer Reflexion im Reich während der Frühen Neuzeit«, in: Malettke, Klaus (Hg.): Hofgesellschaft und Höflinge an europäischen Fürstenhöfen in der Frühen Neuzeit (15-18. Jahrhundert), Münster, 459-490.

Magnusson, Lars (1994): Mercantilism. The Shaping of an Economic Language, London.

Martens, Wolfgang (1996): Der patriotische Minister. Fürstendiener in der Literatur der Aufklärungszeit, Weimar.

Murphy, Antoin E. (2002): John Law. Ökonom und Visionär, Düsseldorf.

Opitz, Claudia/Kleinau, Elke/Weckel, Ulrike (Hg.) (2000): Tugend, Vernunft und Gefühl. Geschlechterdiskurse der Aufklärung und weibliche Lebenswelt, Münster.

Priddat, Birger (1998): Produktive Kraft, sittliche Ordnung und geistige Macht. Denkstile der deutschen Nationalökonomie im 18. und 19. Jahrhundert, Marburg.

Reinert, Erik S. (1999): »The Role of the State in Economic Growth«, in: Journal of Economic Studies 26, No. 4/5, 268-326.

Reinert, Erik S. (2009): »Johann Heinrich Gottlob von Justi (1717-1771): The Life and Times of an Economist Adventurer«, in: Backhaus, Jürgen Georg (Hg.): The Beginnings of Political Economy: Johann Heinrich Gottlob von Justi, Berlin, 33-74.

Reinert, Erik S./Reinert, Hugo (2009): »A Bibliography of J.H.G. von Justi«, in: Backhaus, Jürgen Georg (Hg.): The Beginnings of Political Economy: Johann Heinrich Gottlob von Justi, Berlin, 19-31.

Sandl, Marcus (1997): Ökonomie des Raumes. Der kameralwissenschaftliche Entwurf der Staatswirtschaft im 18. Jahrhundert, Köln-Weimar-Wien.

Schefold, Bertram/Rieter, Heinz (1993): Glückseligkeit und Wirtschaftspolitik. Zu Justis »Grundsätze der Policey-Wissenschaft«, Düsseldorf.

Schneider, Ulrich Johannes (Hg.) (2006): Seine Welt wissen. Enzyklopädien in der Frühen Neuzeit, Darmstadt.

Schneider, Ulrich Johannes/Zedlmaier, Helmut (2004): »Wissensapparate. Die Enzyklopädistik der Frühen Neuzeit«, in: van Dülmen, Richard/Rauschenbach, Sina (Hg.): Macht des Wissens. Die Entstehung der modernen Wissensgesellschaft, Köln-Weimar-Wien, 349-363. 
Schneider, Ulrich Johannes (2012): Die Erfindung des allgemeinen Wissens. Enzyklopädisches Schreiben im Zeitalter der Aufklärung, Berlin.

Stapelfeldt, Gerhard (2006): Der Merkantilismus. Die Genese der Weltgesellschaft vom 16. bis zum 18. Jahrhundert, Freiburg.

Stanitzek, Georg (1987): »Der Projektmacher. Projektionen auf eine sunmögliche< moderne Kategorie«, in: Ästhetik und Kommunikation, 17. Jg., H. 65/66, 135-146.

Tribe, Keith (1987): »Justi, Johann Heinrich Gottlob von (1720-1771)«, in: The New Palgrave: A dictionary of Economics, Bd. 2, London, 1039.

Tribe, Keith (1988): Governing Economy. The Reformation of German Economic Discourse 1750-1840, Cambridge.

Tribe, Keith (1995): Strategies of Economic Order. German Economic Discourse (1750-1950), Cambridge.

Weckel, Ulrike/Opitz, Claudia/Hochstrasser, Olivia/Tolkemitt, Brigitte (1998): Ordnung, Politik und Geselligkeit der Geschlechter im 18. Jahrhundert, Göttingen. 


\title{
The Darién Scheme
}

\section{Failure and its treatment in the press}

\author{
Claudia Claridge
}

\section{INTRODUCTION}

In the years 1695 to 1700 a Scottish company's attempt to establish a colony in Darién resulted in utter failure. In the eyes of at least some Scots the repercussions from this led to an even greater failure, namely the loss of Scottish independence in entering the Union with England (1707). While an absolute causal connection between the two historical events cannot necessarily be made, perceptions of course have a reality of their own. What is certainly at issue in both cases is the relationship of the Scots and the English, the loss-gains balance for both sides, (ascribed) good vs bad will and degrees of (mis)trust. This chapter, while providing an outline of events in section 2, deals not so much with the political and economic matters of this affair as with the reactions to it in print. The Darién Scheme was amply discussed in writing, as for example the Spencer Collection (cf. Glasgow University Library) or a search in EEBO illustrate ${ }^{1}$, both before, while and after the main events. Focusing mainly on the pamphlets published immediately at or after the time of failure, I will look at arguments regarding why the Scottish colonial enterprise ran into trouble and at how

1 | Glasgow library links: www.gla.ac.uk/services/library/collections/virtualdis plays/collectionhighlights/spencer/ and http://eleanor.lib.gla.ac.uk/search $\sim \mathrm{S6}$ ? $/$ fsp +coll+spencer/fsp+coll+spencer/ $1 \% 2 \mathrm{C} 131 \% 2 \mathrm{C} 170 \% 2 \mathrm{CB} /$ browse/index sort=-. On both EEBO and ECCO a search such as Darién or Caledonia will find a considerable amount of useful material, e.g. Darien 36 and 31 records respectively, Caledonia 29 and 85 records (not all of them immediately relevant, of course). 
these were rhetorically presented. For this a discourse analytical approach will be applied, to be introduced in section 3. Before the actual analysis in section 5, we will briefly look at the expectations connected with Darién (section 4), as the degree of failure can often only be measured by the original goals.

\section{An OUtLine OF EVENTS²}

The foundation of a colony in Darién, situated on the isthmus of Panama, was the brainchild of William Paterson, a well-known Scottish projector of the time and co-founder of the Bank of England (1694), his most successful and long-lasting project. ${ }^{3}$ Inspired by his ideas the Scottish parliament created the Company of Scotland in 1695 , giving it an extensive trading monopoly as well as the right to take possession of uninhabited territories. From 1695 to 1697 preparations for the first expedition of the company with the (supposedly secret) destination Darién were underway, including raising money, acquisition of ships and provisions, recruiting colonists. The efforts to raise money for the company early on ran into problems: after a very promising start to collecting London subscriptions the protest of English traders caused a political intervention and the collapse of London financing. This was partly the effect of the Scottish parliament, while paying attention to all formalities, having neglected to really consult King William about the Company. ${ }^{4}$ The hostile English reaction also led to the blocking up of financing avenues in Germany and the Netherlands. Thus, the Company had to fall back wholly on the financial resources in Scotland, a country with few resources and, moreover, economic problems at the time. Nevertheless, 400,000 pounds were raised quickly at the beginning of 1696 , with subscribers representing all classes and institutions of Scottish society. In July 1698 , the first expedition finally started with five ships containing 1,200 Scottish colonists (including William Paterson and family) and arrived in Darién in November 1698, a destination none

2 | The following summary of events is based on Prebble (1968) and the documents collected in Pratt Insh (1924).

3 Another of his successful projects was Walpole's sinking fund. Cf. the contribution by Brakensiek (this volume) for more information on Early Modern projectors. 4 | Davies (1999), 671. 
of the colonizers had first-hand knowledge of. Nevertheless, their view was that this was territory not in possession of any European power and that Scottish possession could be negotiated with the native inhabitants. The colonists set about constructing a settlement ('New Edinburgh') and a Fort named St. Andrew, drawing up rules for the colony and electing a kind of government. The beginning was marked by a grand declaration:

And now by Virtue of the before-mentioned Powers to us given, We do here Settle, and in the Name of GOD Establish Our Selves, and in Honour, and for the Memory of that most Ancient and Renowned Name of our Mother Kingdom, We do, and will from hence-forward call this Country by the Name of Caledonia: and our selves, Successors, and Associates, by the name of Caledonians. ${ }^{5}$

But in the face of inadequate and depleting provisions, lost supply and relief ships, as well as diverse adversities such as diseases, incessant rains and storms, internal quarrels, and a Spanish attack, the colony dwindled to three quarters of its original strength in the first six months. Negotiations and wished-for alliances with the native population also led to no material results, as the Scots simply did not understand the tribal dynamics in Darién. ${ }^{6}$ In this situation (May 1699) the colonists learned of English proclamations to all governors of English colonies in America forbidding assistance to the Scottish colonists of Darién in any way, on the grounds that King William was not informed of the scheme and that it was against the peace with his allies (the Spanish). Therefore, and because of a rumour of another Spanish attack, the colonists decided to abandon the settlement in June 1699. Ignorant of that, two more relief ships with 300 settlers left Scotland in August 1699, one of which burned within sight of Darién, the other retreated to Jamaica. Also, a full second expedition with four ships and 1,300 colonists arrived in November 1699; they rebuilt the Fort St. Andrew and waited for the Spanish attack, which ended in Scottish defeat by April 1700. English help was explicitly denied in this situation. The Scots were allowed by the Spanish to sail off with their remaining people and possessions, which due to sorry states of their ships turned out not to be

5 | Quoted in Prebble (1968), 141. The choice of the name Caledonia is noteworthy for the associations this old Roman term for Scotland carries (antiquity, authority, importance).

6 | Cf. Gallup-Diaz (2002), chap. 4 for a detailed account of the Darién situation. 
an easy undertaking. Only one ship, the Caledonia, made it back to Scotland, and only one ship involved in the whole expedition was still afloat at the end of 1700 - the others had either sunk ( 3 ships), burnt (1), been otherwise ship-wrecked (1), been abandoned as not seaworthy (2), or lost to the Spaniards (2). ${ }^{7}$ Of the 3,000 would-be colonists the great majority had died one way or another, while some had ended as indentured labourers or as pirates. Most Scottish families in the lowlands had been directly affected by losing a family member in the undertaking. And many Scots were ruined following their investment in the Company's Darién scheme. The affair only reached its ultimate end seven years later, when in the context of the Union between England and Scotland the so-called equivalent ${ }^{8}$ was used to compensate losses incurred in the Darién desaster.

\section{Data and Analysis}

The data to be investigated consists of pamphlets and other ephemeral texts published at the time of the Darién project, mostly in 1699 and 1700. The overall context of these texts is that of an "information revolution", with the press playing a very important role in British society and politics at that time. ${ }^{10}$ The immediate context of the Darién texts was an ongoing public/press discourse on the (nature of) the British union. ${ }^{11}$ In this situation, pamphlets and other fairly short publications, which could be produced quickly, were the major means of creating and influencing public opinion. Political discussion typically found its outlet in pamphlets, which were seen as appropriate in both length and text type to develop a line of

7 | The colonial failure is thus strikingly embodied by shipwreck, which provides a link to the German etymological conception of Scheitern as literally breaking into its wooden bits, as described in the contribution by Wesche (this volume), although the relevant English words have another history (cf. the introduction).

8 Article XV of the Act of Union: "It is agreed that Scotland shall have an equivalent for what [her] subjects shall be charged towards payment of the debts of England [...] the sum of three hundred ninety-eight thousand and eighty-five pounds ten shillings."

9 | Smith (1994), 1.

10 | Alston (1981), 333 and Sommerville (1996), 163.

11 | Bowie (2007), 67. 
argument and to interact with opposing views. ${ }^{12}$ Pamphlets thus were often very specialised in content, focused on current affairs, directed at very specific other texts and their authors as well as written with fairly specific audiences in mind.

The Darién pamphlets are of exactly this type. Most of them are (very) long argumentative, even polemical pamphlets, but some of them are also rhymed pieces like praise poems or ballads (the texts used here are listed in the appendix). The authors fall into two camps: the pro-Scottish group defending the undertaking and finding face-saving justifications for its failure (or still trying to avert failure) vs. the anti-Scottish faction attacking and blaming the Scots for their incompetence. Anti-Scottish in this particular case equals (pro-)English, as the constitutional set-up (one monarch, but two states on the British island) and geopolitical situation led to conflicting English and Scottish interests. Thus, for both sides in this 'pamphlet war' it is to a certain extent a question of an us vs. them situation, ${ }^{13}$ visible also in some of the author pseudonyms chosen (Philo-Caledon, Phil.Scots vs. Philo-Britan). A (critical) discourse-analytic approach to these texts is thus suitable, which, according to van Dijk, "aims to show how the cognitive, social, historical, cultural, or political contexts of language use and communication impinge on the contents, meanings, structures or strategies of text". ${ }^{14}$ In this approach, texts are seen to both embody and construct (or construe) beliefs and ideologies ${ }^{15}$ - here the Scottish world-view, as this will be the focus in this paper. The particular perspective shaping the text is visible through the choices made by the author (which need not and will not all be conscious ones), such as:

- which (type of) arguments are chosen, i.e. what is presented as 'fact', as an appropriate representation of reality;

12 | Sommerville (1996), 122 and Ahrens (1991), 21.

13 | Cf. Bös (this volume) for another instantiation of this common antagonistic set-up.

14 | Van Dijk (1991), 45. For another example of historical discourse analysis, also involving Scottish and English relations, cf. Prentice/Hardie (2009).

15 | "Discourses are semiotic ways of construing aspects of the world (physical, social or mental) which can generally be identified with different positions or perspectives of different groups of social actors." Cf. Fairclough (2009), 232. 
- which lexico-semantic selections are found that imply or enforce certain conclusions (modern examples are freedom fighters vs. terrorists, metaphors like axis of evil with its moral/religious implications).

Here, it will be especially of interest how such choices construe the English and the Scottish and their respective actions. Given the nature of the textual basis (namely pdfs) the analysis will mostly be of a qualitative and exemplary kind. As has been found, however, it is often not simply individual uses that have an impact, but larger patterns of (co)occurrences and frequencies in texts (versus those in other texts), cf. corpus-assisted discourse studies. ${ }^{16}$ As one of the Darién texts also exists in a digitised and searchable format (in the Lampeter Corpus), this approach will also be made use of to a certain extent.

\subsection{Previous research}

The writings on Darién have not received much attention from the linguistic side. Two papers by Marina Dossena ${ }^{17}$ treat specific linguistic features contributing to the argumentation in various pamphlets in some detail, thereby also showing the interpersonal and involved features of these texts. These features are modal verbs of necessity/obligation and of certainty/doubt, the use of Latin, the quotation of proverbs, biblical metaphors, the switch to colloquial language and in general verbal aggression. She shows how insults are directed both at individuals (e.g. Harris, one of the pamphlet authors and a participant in the Darién expedition: a Monster) and groups (e.g. Highlanders as the only ones to eat food not even fit for dogs), with the authors frequently slipping into colloquial or dialectal language at such points (e.g. Paterson described as tasting the Creature, a Scotticism for whiskey). ${ }^{18}$ Biblical (or generally religious) allusions, references and imagery are used to lend greater strength and authority to arguments. Thus, the situation in the New World is couched in religious

16 | Cf. Partington (2008).

17 | Dossena (2003) and Dossena (2006).

18 It needs to be said that such impoliteness is not specific to these pamphlets. Interactions in early modern England, roughly before the middle of the $18^{\text {th }}$ century, are marked by greater directness, higher emotive involvement (in writing), and impolite, even rude behaviour, cf. for example Claridge (2000) and Bös (2007). 
metaphors in the following passage, inviting the English to join the Scots in challenging the Spanish "antichrist".

for we have as good reason to look upon the Spanish Mines in the West-Indies to be Antichrist's Pouch, by which he maintains his War against the Church, as the old Taborites had to call the Silver Mines in Bohemia by that Name. It is certainly the surest Method of destroying Antichrist, to seize his Purse; for if he once be depriv'd of Judas's Bag, he will quickly drop St. Peter's Keys. It's by the Charms of her Gold that the Babylonish Whore hath made the whole World to wonder after her, and the Kings of the Earth to be drunk with the Cup of her Fornication. (Defence, 1$)^{19}$

Similarly to religious content, also the use of Latin lends credibility and authority to the points made by an author. Respected ancient and modern authors, such as Cicero, Seneca, and Puffendorf, are quoted and then translated for the benefit of a wider audience. Some foreign material is proverbial (e.g. sed quos deus or Jupiter perdere vult eos dementat), and like the native proverbs (e.g. save a rogue from the gallows he shall be the first that will cut your throat) also employed, activates common and readily accepted knowledge in the minds of readers, therefore involving them more deeply in the argumentation. Other means of involving and convincing the reader are the use of questions, the use of reader-inclusive we and direct reader address (you). The greater frequency of possibility and prediction modals highlight the type of argumentation used, namely discussing likely or unlikely outcomes if certain routes are (not) taken.

Further strategies employed in these pamphlets will be illustrated below (section 5).

19 | Original texts are quoted by a short-title reference, indicated in the listing of texts in the References section. 


\section{Great expectations}

The time and expense of navigation to China, Japan, the Spice Islands, and the far greatest part of the East Indies will be lessened more than half, and the consumption of European commodities and manufactories will soon be more than doubled. Trade will increase trade, and money will beget money, and the trading world shall need no more to want work for their hands, but will rather want hands for their work. Thus, this door of the seas, and the key of the universe, with anything of a sort of reasonable management, will of course enable its proprietors to give laws to both oceans, and to become arbitrators of the commercial world, without being liable to the fatigues, expenses, and dangers, or contracting the guilt and blood, of Alexander and Cesar. (Paterson, Proposal, 1701)

These are some of the words with which William Paterson pursued his Darién scheme even after the failure. It can be assumed that he used similar rhetoric when he originally convinced the Scottish Company to set its aims on Darién as opposed to other places. Paterson's line of reasoning is that the narrow isthmus provided by the location will enable easy travel from the Atlantic to the Pacific Ocean. This is taken up in other writings, e.g. one of the pamphlets, which states that the situation is "very commodious for a speedy and short Communication of Trade betwixt the North and South Seas" (Defence, 61). Starting with optimistic, but still reasonable points Paterson takes off on hyperbolic flights in the second half of the above quote. Even the reasonable aspects, although they may be vindicated by the later Panama Canal, present, however, a very high aim for a nation like Scotland with not one single successful colonial enterprise on its record. The promise is that one place alone, serving as a trade emporium, will cause the nation to be in possession of a more powerful economic power than all the others. Of course, this is sales talk, but it caught on, even with hindsight Lord Belhaven talks about the "great hopes and expectations we had" (Speech, 7) without calling them misguided. And it is visible not only in the Scottish willingness to finance the undertaking, but also in (more or less) poetical outpourings.

In various occasional poems we find Scottish hopes expressed. Both $A$ Congratulary Poem and An Ode made on the welcome news envisage Scotland as overcoming poverty. The Congratulary Poem still couches this in modalised and wishful terms (cf. underlining), but the aim is clear: trade profits and also treasure from the colony are to ensure long-lasting wealth. 


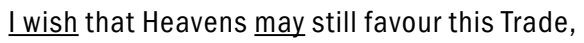
Under the Indian Pole, and Treasure hade

Worthy the pains and Travel you are at,

T'enrich this Land was long Depauparat, That Scotland may yet Flourish and and in Peace,

Preserved be from all seek to deface, Its fame, so that its Honest industrie,

May Persever to all Posterie,

(A Congratulatory Poem $)^{20}$

An Ode sounds more self-assured, using will and shall instead of the more uncertain may, as the following two stanzas show. It too expects direct profits from the colony, in the form of 'Indian Gold', a usual European expectation in the case of Middle and South American locations. ${ }^{21}$ This will heal Scotland's "grand disease", namely its poverty, and, more precisely, will give all its citizens work to support themselves (no sons without a future, no beggars and vagabonds).

The Countrey now will be at ease, the tender Mothers will no more their Sons Uncertain Fate deplore; And Indian Gold shall soon release The Nation from its Tempral Grand Disease

(An Ode made on the welcome news [...], Edinburgh 1699)
No swarms of Beggars shall annoy, no Vagabounds corrupt our Wealth; but every Man that enjoys Health, His frugal Countrey shall imploy T'increase our Store, \& crown our lasting Joy.

Together with the promising consequences for Scotland, the situation in Darién is also painted in rosy colours, as the following extracts from Caledonia Triumphans illustrate:

Fourth of November, that auspicious Day, Your valiant SCOTS their Colours did display, Into the Western World, where they did meet, Thousands of Welcomes prostrat at their Feet.

20 | Italics in the texts quoted are original. Highlighting by me is done by way of underlining.

21 | Cf. Pointner (this volume). 
$[\ldots]$

At Landing, Fertile Fields and Golden Mountains,

Saluted them, with clear and christal Fountains;

Roots, Flowers and Fruits, for Physick, and to eat,

And neither pinching Colds, nor scorching Heat.

Rivers, safe Bayes, variety of Plants,

And useful Trees which our old Britain wants.

(Caledonia Triumphans, Edinburgh 1699)

Both the climate, the geographical features and the fauna of Darién are described as providing ideal living conditions as well as diverse potential benefits. The positive reaction of the native population to the Scottish arrival is overstated with European colonial arrogance. As outlined above, the actual situation was less beneficial and more complicated. The Scots also had delusions about important things closer to home, thus the same poem confidently states "What humane Counter-plot can marr the thing,/ That is protected by Great-Britains King", and The Golden Island adds "King WILLIAM did encourage us/against the English will" - although no explicit royal approval had been sought or provided.

As the last quote shows, the competition with England, Scotland's more powerful neighbour, is an important issue. In the words of The Golden Island, the Darién project, which it calls a "noble interprize", is also a matter of "the Thrissel in the Lyons hand "gainst Leopards and Rose", using the national heraldic symbols metonymically for the two nations. ${ }^{22}$ Another passage of the same poem talks more explicitly of enemies and also of victory by Scotland:

The Thristle and the Reed Lyon,

will Crush our Enemies.

We're Antipods to England now,

win by a pleasant Toil.

(The Golden Island or the Darian Song, Edinburgh 1699)

22 The Scottish national flower is the thistle (spelled variously in the poem). The English leopards are also called lions sometimes; in contrast to the Scottish (red) lion rampant, they are passant gardant in heraldic terms. 
The term antipodes seems to be used metaphorically here, as 'opposites' in the sense of 'opponents', more specifically probably 'opponents of equal standing' (geographically, and given the overall colonial situation, the English, and the Scots in Darién were not antipodal to each other). Thus, Scotland is not only seeking material gains through its colonial undertaking but also national reputation and political clout. Among the aims one thus finds also "That all the Neighbouring Nations yet may own,/SCOTLAND deserves still Honour and Renown" (A Congratulatory Poem). The neighbouring nation of most interest was clearly England.

As this short overview shows, Scottish expectations were indeed great, with respect to the nature of Darién, material gain to the mother country, and a boost to the national psyche. Expectations of such grandeur are easy to disappoint and if spectularly disappointed, as in the present case, the contrast between wish and reality makes things even harder. A narrative exculpating Scotland (at least to some extent) had to be found, which will be the topic of the following section.

\section{Making sense of failure}

In 1699 it was gradually becoming known in Scotland that the Darién undertaking was not going according to plan, and by 1700 it was clear that Scotland's colonial hopes had not only failed, but done so spectacularly. Pro-Scottish pamphlets appearing in these two years, plus some from 1701 and 1705 , will be examined as to their content arguments, their representation of the English and the Scottish respectively and their adversative grammatical structures.

\subsection{Constructing the Scottish view-point}

An early apologetic pamphlet in this matter, Philo-Caledon' ${ }^{23}$ A Defence of the Scots Settlement at Darién from 1699, still hoped for a positive outcome and thus in a sense is argumentatively still fighting an impending failure. The pamphlet treated the matter under the following four headings: (i) "The Legality of the Scots Establishment", (ii) "The Advantage or

23 | Philo-Caledon has been variously identified as Archibald Foyer, Andrew Fletcher and Lord Belhaven. 
Disadvantage that may redound from it to England," (iii) "Whether the Scots without the Assistance of the English may be able to maintain their footing in America", (iv) "and what may probably be the Consequences if the Scots should be oppos'd therein by the English, and miscarry in the Undertaking” (p. 1, numbering added). As to (i), the pamhlet points out that the Scots "were authorized by an Act of Parliament, and the King's Letters Patent, to plant Colonies in Asia, Africa, or America, upon Places not inhabited, or any other Place, by consent of the Natives, not possest by any European Prince or State" (p. 14) and that Darién was not in fact under Spanish jurisdiction, thus free for the taking by the Scots. ${ }^{24}$ The quotation below concerns a Spanish document sent in protest to the British Monarch, belittling it by the choice of characterising nouns and by not even finding it deserving of refutation.

It were easy to make proper Remarks upon the Weakness, Insolence and Ingratitude of this [the Spanish, CC] Memorial, but it is not worth while; (Defence, 3)

By charging Spanish insolence and ingratitude against King William, the author positions himself on the King's side - in line with his aim of having him (and the English) on the Scottish side. After extensive discussion the pamphleteer comes to the conclusion that the Spaniards have no right to Darién:

It is evident that the Spaniards cannot pretend a Title to that Country by Inheritance, Marriage, or the Donation of Prince and People; and as to Conquest it would be ridiculous to alledg it, (Defence, 4)

Of especial importance for the author is also the fact that there is evidence that even the English considered Darién not subject to Spain in the past implying that they should also do so now. As to the second point above, the (dis)advantage to England the author points out that the Scottish Darién scheme, if successful, would profit both English (overseas) trade and the English economy as such, give England a strong political ally (with Scotland as a naval power) and be good for the Protestant interest in general.

24 | The Spanish (and English) colonial context is treated equally, but much more detailed and with discussion both of historical facts and legal literature by Ferguson (Vindication). 
Here, as elsewhere in the text, the author has reepeatedly recourse to historical argumentation:

It will effectually unite the Scots to England by an inseparable Tie, if the English join us in this Undertaking: Their Ancestors would have gladly purchased this Union at a much dearer rate, but were always outbid by France: and the want of that Union made the English not only an easy Prey to their successive Conquerors, but lost them all the large Provinces that they enjoy'd beyond Sea, which were their natural Barriers, gave them a free Access to the Continent, and made the English Name so glorious in the days of their Ancestors. (Defence, 21-22)

The point here is that England is and has been weakened by the lack of strong ties, even a union, with Scotland. While the historical truth of this is extremely doubtful and Scottish importance overstated, the aim is clearly to sell cooperation on Darién to the English because of larger gains arising from it. With regard to the following point, continued Scottish presence in America, the author is exuding optimism; with hindsight one might say he was hoping for a self-fulfilling prophesy. With regard to the last point he resorts heavily to historical argumentation again, where a very bitter note creeps into the text. Present English ingratitude is juxtaposed to everything the Scots did for England in the past, such as Scotland "being so instrumental to rescue them [the English] from Anarchy and Confusion, by the Restoration of K. Charles II. and above all, our generous and frank Concurrence with them in the late happy Revolution, and Advancement of K. William III.” (p. 30). The author also stresses that history shows the English that "we always broke their Yoke at long-run, if at any time we were brought under it by Force or Fraud. The best way to assure themselves of us is to treat us in a friendly manner:" (p. 41). In this part, the author also goes to some trouble to divide the English into good and bad, so to speak, by blaming a certain "faction" for opposition to the Scottish plans - while sensible Englishmen should certainly react differently:

however we be despis'd and undervalued now by a certain Party in England. (Defence, 35)

the Malice of a Faction in our neighbouring Nation fix'd a scandalous Reproach upon us (Defence, 44)

our wise and politick Neighbours will at last see it their Interest to protect and incourage us in this matter (Defence, 50) 
This already points in the direction in which the argumentation of the next paper to be treated goes.

In 1700 the failure of the Darién undertaking was beyond doubt. In this context, finding reasons for the failure also implied identifying culprits. While for the anti-Scottish writers these are clearly the Scots themselves, i.e. the Company and the colonists, the matter is more complex for pro-Scottish writers. A consideration of An Enquiry into the Causes of the Miscarriage of the Scots Colony at Darien (1700), attributed to Ridpath, ${ }^{25}$ can illustrate this. Naturally, Ridpath wants to keep the Scots free of blame, but he also wants to avoid making King William seem responsible and he does not want to accuse the whole English nation as such. The strategic aim behind this must be that the Scots may very well need the good will of either or both of them in the future. The author of a rival pamphlet, $H---s$, thus serves as Ridpath's overt main target, whom he styles as the frontman of an anti-Scottish clique. $H-s$ himself, either Harris or Hodges, ${ }^{26}$ is described by various epithets and attributes, for example "this unnatural Renegado" (62 and passim), "this malicious Scribler" (70), "Libertine" (97), and as having an "Irreligious and Atheistical temper" (82), which are meant to damage him on national (traitorous), moral and religious grounds. If that author is indeed Walter Harris, the character demolition is necessary from a Scottish viewpoint in order to discredit somebody who, after all, was an eyewitness to Darién events. Repeatedly, the pamphlet speaks of "H-s and his Suborners" (e.g. p. 66), i.e. people who incited $H$---s to his crime of 'smearing' the Scots (and allegedly also paid him for it). The Suborners are apparently to be found "at the West End of the Town [=Westminster/London, CC]" (p. 73), that is a group in or close to the English government. Ridpath thus identifies this "Faction in England" (76) as the enemies of Scotland's colonial aspirations. The attack on Scotland in opposing pamphlets is claimed to be an evasive action, with the aim of "clear[ing] some Gentleman that perhaps may be found within the Verge

25 | George Ridpath was not only a pamphleteer, but also ran the newspaper The Flying Post (mentioned in Bös, this volume).

26 | EEBO states about this pamphlet that it was "variously attributed to James Hodges, Walter Harris, and Archibald Foyer." Regarding Walter Harris, GallupDiaz makes the point that he was a client of the English Secretary of State, James Vernon (chap. 4, fn 99). Thus, in spite of the fact that he had taken part in the Darién enterprise as a surgeon he was writing from an English perspective. 
of White-Hall, from having any hand in it [the failure of Darién, CC]" and to hide the fact that "the Crime is very black" (1). In identifying this faction, Ridpath avoids being "so unjust as to charge it upon the Nation" (76), also called "the good People of England" (58) and "our good Neighbours", who are "much surpriz'd and displeas'd with our Treatment" (63). While clearing the English people is fairly easy, clearing the King without damaging him in some other way or other is more complicated. Ridpath attempts a rhetorically clever operation by inverting the King's own statement (the part underlined):

Then let the World judg, whether the King of England had not less reason to say that he was ill serv'd in Scotland, than the King of Scots had to say that he was ill serv'd in England (Enquiry, 34)

In doing so, he highlights a basic problem in the set-up of the Union of the Crowns without a corresponding Union of Parliaments: with two 'independent' states having separate interests and policies, the joint monarch is put into a kind of schizophrenic position. In the business of Darién the King of Scots, the second persona of William, apparently had lost out and the culprit is this alleged faction in England, as the following quotes imply.

From all which it is plain, that as it is the best Apology that can be made for the King of Scots when he acts thus, contrary to the Honour and Interest of himself and his Country, to say, he is a Prisoner in England; (Enquiry, 36) our King is in the hands of our Enemies, since we are thus condemn'd without a hearing (Enquiry, 39-40)

Thus, it is not King William himself, who is intending to harm the Scots but people who are exerting a bad influence on him. However, this is a tricky argument. The king after all is supposed to be in full charge and knowledge of the state of affairs, he is not supposed to be swayed by factional interest. The attempted clearing of the king thus backfires somewhat by leaving a blemish on his character and his qualities of leadership; the same applies to a similar attempt by Ferguson (Vindication, p. 45).

Another text from 1699, A Short and Impartial View of the Manner and Occasion of the Scots Colony's coming away from Darien, attributed to Andrew Fletcher, goes about the matter again in a different way. Three 
aspects were singled out for discussion, namely the responsibility of the directors of the Company, the potential faults of the colonists, and the effect of "His Majesty's Proclamations". While the author admits some shortcomings and problems regarding the first two aspects, he on the whole absolves both parties from blame. The directors are said to have behaved admirably given the circumstances, but were slandered:

intolerable Liberty Malice, Envy and Ignorance have, as it were, combined together to derogat from the just Merit of those Noble and Worthy Persons, who are concerned in the Management of the Company, by endeavouring to asperse their Conduct (View, 21-2)

A similar exoneration of Scottish actors is found in a eulogistic passage in Belhaven's speech (p.8). This shows the self-serving bias treated in more detail in Bös (this volume), namely the dissociation from one's own faults and blaming others instead. The author then berates the slanderers, with all the authority he can muster, quoting not only the Bible but also respected classical authors such as Horace and Juvenal. The greatest blame thus is put on the English proclamations forbidding support of the Scots (cf. section 2 above), because without these the colonists could have overcome their difficulties. The damaging psychological effect of the proclamations is pointed out, interestingly phrased at crucial points in question form so that the reader becomes directly involved in the thought process:

Must they not think, that since the said Proclamation was published in his Majesty's Name, that undoubtedly it must needs have been legally founded upon some positive Law, tho' they knew nothing of it? And must not the Consideration of all these together have distracted and confounded the Thoughts, Resolutions, and Measures of any Sett of Men that could have been in the Colony? [...] And in that same case, they must have resolved to have been dis-owned by Scotland, as well as by England: And if so, pray from whom then must they have expected Protection? (View, 29)

But instead of stopping with the psychological and material effects of the proclamations, the author thinks one step further. After mentioning that the King might perhaps not have had knowledge of the proclamations at the time, he procedes to the following statements: 
I remember the judicious Montaigne, in this political Essays, observes it, as a Misfortune commonly incident to a Nation that is under the Government of a Prince living in another Country, That any Nation so stated, is seldom or never Govern'd according to the real Inclination of the Prince, or the true interest of the People; so much as according to the Humors, Affections, and Designs of his Ministers: For that he seeing only with their Eyes, and hearing but with their Ears, cannot possibly know the true State, Condition and Interest of a Distant Nation, nor the Humors and Inclinations of its Inhabitants, any thing near so well as if he lived amongst them. (View, 35)

He essentially points out here that the British set-up of the Union of the Crowns cannot work, or at leat not to the equal satisfaction of all parties involved. Thus, he lays his finger on a larger political, namely constitutional failure, but without spelling it out fully. The Scottish king being made to act against Scottish interests through the influence of his English ministers is also part of the larger union debate going on at the time. ${ }^{27}$

\subsection{Taking sides: lexico-semantic choices}

With the help of the one digital text it is possible to perform a keyword analysis, i.e. a procedure that statistically calculates which words are statistically significantly more frequent in this text than in a larger group of comparable texts - as well as those that are noticeably less frequent. ${ }^{28}$ Needless to say, words that are extremely topic-specific will appear here (e.g. Darien itself, Spaniards, Indians, America, Panama, colony, proclamation, Ambrosio = the name of one of the native chiefs), but also words that are less self-evident and more telling for an interpretation. Disregarding the very obvious words, the following are some of the meaningful keywords:

Scots, English, England - us, we, our - they, their

union, alliance-crowns, K. (= King)

join, joining

interest

ancestors

treated

27 | Bowie (2007), 68.

28 | This was carried out with the help of WordSmith Tools 5.0. The Darién pamphlet was compared to the 19 other political pamphlets in the Lampeter Corpus. 
While Scots and English might seem too obvious, they are not: both groups are prominent players in British politics in the $17^{\text {th }}$ and $18^{\text {th }}$ centuries, thus occur regularly in political writing, but their frequency here, together with the prominent first and third person plural pronouns, point to an importance even greater than usual and to a strong us vs. them depiction. In this context, it is also interesting that $I$ stands out as infrequent (a negative keyword), which means that the persona of the pamphleteer, otherwise often very prominent, is here downgraded in favour of stressing the national we-perspective. The listing above reflects (descending) key-ness order as closely as possible, which means that the form us is more typical than we, putting the Scots in the non-agentive, passive or receiving position. In contrast, they is the subject, i.e. agent, pronoun. This subject-object distribution can be seen nicely in the examples below, as well as the use of treated in a passive construction with the same effect and the overuse of our (which is not grammatically necessary in all cases, e.g in Distress). Partly, this emphasises Scotland's status as the 'wronged' party, but it also shifts the perspective to England - whom, after all, this pamphleteer still wants to convince of a different kind of reaction, namely of supporting the Scots, cf. the keywords interest and join as used in the third example.

to this they have added an opposition to our receiving foreign Subscriptions at Hamburgh and elsewhere, refus'd us a Supply of Corn for our Mony, to relieve us in our Distress; and discourag'd our Settlement at Darien, by forbidding their Subjects to trade with us there. (Defence, 34)

by the Discouragements from England before-mentioned, which exposes our Ships to be taken and treated as Pirates by any Nation that pleases, (Defence, 43) that it is England's Interest to join with and protect us (Defence, 85) ${ }^{29}$

Crown, union and K(ing) repeatedly refers to the common bond between England and Scotland by sharing a monarch and common interests. These words are often found in passages referring to history, which is made even more explicit by the mention of both English and Scottish ancestors, reminding the readers that there once was a better mutual relationship, e.g. "they may be pleas'd to consider the honorable Privileges granted us by

29 | The underlined words in these examples are all statistical keywords. 
their Ancestors". In contrast to union, alliance is used referring to a wider political range, and it is even partly used in threats, cf.:

we shall only desire them to consider how fatal it may be to them, if by any Emergency we should be forc'd to break off the Union of the $\underline{\text { Crowns, }}$, and enter again into a French Alliance. (Defence, 56-57)

The keywords thus highlight how this text uses the joint and sometimes grievous history of England and Scotland, as well as threats of other political orientations, to convince the English that it is in their interest to support the Scottish colonial undertaking.

Apart from keywords, there are also other lexical choices and patterns of interest. The English-Scottish political relationship, for example, is repeatedly phrased in kinship terms. The English are called Brethren (the word form with religious colouring, vs. more neutral brothers) and Scotland is described as the Sister-Nation of England (Defence, 43). The Darién colony is called infant, in relationship terms thus a child of Scotland and (mentally extending the metaphor) nephew/niece of England. The King unsurprisingly is called Father of the country, having paternal affections (Defence, A4, 86). This is both friendly and, to a certain extent, inspired by wishful thinking. The same metaphorical field can also be turned to negative use, however, when sentiment becomes more inflamed. In Belhaven's speech (1701) the Scottish infant (here the Parliament Act preceding the colony) is attacked by the English Brethren, the term in this case used sarcastically.

So our Act must be attacked in it's Swadling Cloaths, and persecuted in its Infancy, and that our dear Brethren of England might have the Honour to give us the deadly Blow at one Stroke, [...] they endeavoured to perswade our most Excellent and Gracious King that he was ill served in Scotland. (Belhaven, 8)

Images of fratricide and infanticide are captured up in this passage with all their associations. ${ }^{30}$

30 | "Those who endeavour to destroy the Embrio, are chargeable with a design of preventing the Birth" (Enquiry, 3) uses the same metaphor, but here the infant is the Company and the birth refers to that of the colony. 
Although there is no overt reference to the Bible, this is nevertheless reminiscent of Herod's murder of the babes of Bethlehem. Belhaven's speech dwells on such metaphorical violence somewhat longer, but shifts to a different domain, that of physical violence (perhaps execution) and warfare, thus playing on the conceptual metaphor POLITICS IS WAR: ${ }^{31}$

[they] struck at the Indepency of the Nation, through the Bowels of the Company, they rested not satisfied with all these Injuries, but pursued us to Forreign Countries, and most insolently and impudently, without Warrant from his Majesty, their Residents did not only attack the Company, but, by Consequence, the whole Trade of the Nation, and its Sovereignity, by their Infamous Memorial at Hamburgh. When, notwitstanding of all their Malice, by the Firmness and Resolution of the Company, Equipments were forwarded, and under Sail for America, yet their wicked Designs over-run us, even to the New World [...] the Barbarity and Inhumanity of these Proclamations, and the more unnatural prosecutions of them [...] are such unpardonable Injuries and Affronts to the Law of Nature, the law of Nations. (Belhaven, 8-9)

Mixed with the imagery we find extremely explicit evaluation of the English in this passage: insolently, impudently, infamous, malice, wicked, barbarity, inhumanity, unnatural, unpardonable - words indicating behaviour that violates social and moral norms, even places the targets outside of humankind. While other writers are also critical of the English, such explicit and blatant formulations are not found in the other pro-Scottish pamphlets, which may be partly due to the later time of this piece. ${ }^{32}$ Note, however, how even in the middle of this vitriolic attack, Belhaven takes care to exonerate the King, in line with the strategies of the pamphlets looked at above. That Belhaven is not alone with such assessments of - and lexcial choices for - the English is illustrated by Pill for Pork-Eaters (1705), which is an extented harsh and bitter attack on the English and their dealings with the Scots. Epithets used in it for the English are "rogues", "insolent", or "proud like hell". Two brief quotes can illustrate the sentiment in this piece as well as the fact that Darién was not forgotten quickly:

31 | Cf. Bös (this volume) for a detailed treatment of conceptual metaphors.

32 | It may also be a question of personal style: Belhaven was a sophisticated rhetorician, who seemed to give pathos more weight than logos in his practice. 
Then England for its Treachery shou'd mourn,

Be forced to fawn, and truckle in its turn:

Scots Pedlars you no longer durst upbraid,

And DARIEN shou'd with Int'rest be repaid. (Pill, 4)

$[\ldots]$

UNGEN'ROUS England! at this savage rate,

Still to abuse a Free and Neighbouring State! (Pill, 6)

A somewhat curious lexical choice is found in View, a text that singled out the English proclamations as the biggest culprit. Nevertheless, the text contains various formulations which actually seem to deny any responsibility:

all the Mis-Fortunes that have happened to the Company and Colony (View, 28) whatever may be the Occasion of it, away, you see, they are come, as ill Luck would have it: Quae volunt Fata, non tollunt Vota. (View, 33)

tragical and unexpected emergency (View, 33)

the Disasters and Misfortunes, that have attended the Undertakings of this Company, and really, since the Affections, as well as the Interests of many People seem to be wrapt up in its Fate (View, 38)

Fate and fortune are not something man can influence, instead they imply agentless and unpreventable courses of events. This is apparently not the interpretation the author intends, at least no across the board: English actions are still to blame, but Scottish reactions to them may well be determined by a degree of fate. A further aim may lie in the connotations the words carry: even without negative words and prefixes (ill, mis-), fate would have negative implications. Using these words emphasizes the bad nature of events and of Scotland's present state.

Interesting lexical choices are not only found when making statements about the world, but also in the context of argumentation. In Defence one finds explicit evaluations of the arguments used as in the following examples:

It is evident that the Spaniards cannot pretend a Title to that Country by Inheritance, Marriage, or the Donation of Prince and People; and as to Conquest it would be ridiculous to alledg it, (Defense, 4) 
which is a plain Demonstration that the Government of England did then look upon Darién to be no way subject to Spain, (Defence, 4-5)

when it is so well known to the World that the Crown of Spain has no manner of Title to that Province. (Defence, 6)

The author's own points here are evident and plain whereas the opposing points of view can only be alleged, i.e. have no factual basis. This is common stylistic practice throughout this pamphlet: The words evident, plain, no doubt, and obvious are frequent, occurring about once every 1,000 words; similarly "we could multiply Instances to prove this" stresses the well-foundedness of the argument. Opposing arguments are described, though not quite as frequently, by allege/allegations, being ridiculous, merely pretended, precarious, and perfectly overturned. Hyperbole is used in the last statement above as a strong truth marker: what is so generally known actually needs no arguing. This (colloquial) expression of the world knowing is used four times in the text. Similar strong effects are reached by the heavy and marked negation patterns: instead of simply no(t) we find no way and no manner of. ${ }^{33}$ By using such markers as all the above the writer tries to steer the reception process of the readers, drawing them to his side. This author is not alone in trying to explicitly stress his own conclusions as correct and denigrate those of others, cf. formulations like "it is then Apodictically evident" or others' "allegation [...] offer[ing] violence to common sense" used by Ferguson (Vindication, p. 83, 98); indeed they are common throughout. While this is not uncommon for (polemical) pamphlet literature as such, it of course also highlights very nicely here the two sides involved, the pro- vs. the anti-Scottish.

\section{Conclusion}

As the discussion above has shown, Scottish fault-finding was decidedly one-sided: it was the English or a certain English faction which was to blame for the Darién failure. While there is some truth in this, it is cer-

33 | Similar strategies are also found in other pro-Scottish Darién papers, e.g. "the Directors of our Indian and African Company at home, are no manner of way Chargeable with any Omission" (View, 4). It is noteworthy that thus an already marked strategy like negation is made even more marked. 
tainly not the whole story. There were also aspects the Scots could have handled better, such as early negotiations with the king (in the context of the Act) or acquiring better information about Darién's situation, inhabitants and colonial context. They may have also not been completely honest about the purpose of their colony; for a peaceful philanthropic undertaking there were a surprising number of military men in the expeditions. ${ }^{34}$ Nevertheless, in the overall context of European colonialisation the Darién circumstances do not exhibit incompetence to a noteworthy high degree. And it was certainly not the first colonial effort to fail - it was just that fairly impoverished Scotland, which was broke after Darién, could not digest this failure easily. Thus, the need for a scape-goat. The preoccupation with the English goes deeper than the Darién events, however. As various documents (e.g. Vindication, Defence, Pill) amply show it is the whole of Scottish-English historical relations that rankle with the Scots. Darién was only one straw in the line of many, from the Scottish perspective, and it may have been the one that broke the camel's back (if there is indeed a causal line leading from Darién to the Union).

Apart from the more multi-faceted state of affairs, the one-sidedness of the publications is not surprising. On a general level, this is the nature of most pamphleteering of the time: it is usually partisan, single-minded, polemical and often downright rude to opponents. In these circumstances, black-and-white textual pictures are much more common than those containing nuanced shades of grey. Thus, English pamphlets on Darién, for example, simply blamed the Scots. ${ }^{35}$ In our specific case, the pamphleteering happened in the context of a court-country factional division in the Scottish parliament, with the country party actively using the press to induce political action, such as producing the 'right' mood for the signing of national petitions. ${ }^{36}$ The same way modern newspapers have a clear political alignment, e.g. The Guardian vs. The Daily Telegraph, pamphlet(eer)s were also aligned along political lines. The pamphlets treated in chapter 5 represent the views of the country party, which, among others, deplored English influence on the monarch and the relative loss of importance of the Scottish parliament. Both of these were of course prominent aspects in the Darién case.

34 | Gallup-Diaz (2002), chap.5, p. 13 (the chapters are paginated individually).

35 | Bowie (2007), 88.

36 | Bowie (2007), 32. 


\section{References}

\section{Source texts}

An Congratulatory Poem on the Safe Arrival of the Scots African and Indian Fleet in Caledonia [...], by R.A. (no place/date).

An Ode made on the welcome news of the safe arrival and welcome reception of the Scottish Collony at Darien in America, Edinburgh 1699.

Belhaven: A Speech in Parliament on the 1oth. day of January 1701, By the Lord Belhaven, On the Affair of the Indian and African Company, and its Colony of Caledonia. Edinburgh 1701.

Caledonia Triumphans: A Panegyrick to the King, Edinburgh 1699.

Defence: Philo-Caledon, A Defence of the Scots Settlement at Darien, with an Answer to the Spanish Memorial Against it and Arguments to prove, that it is in the interest of England to join with the Scots, and protect it [...] Edinburgh 1699. [by Archibald Foyer, Lord Belhaven?, Andrew Fletcher?, EEBO: also attrib. to George Ridpath, Walter Harris (Digital version: Lampeter Corpus of Early Modern English Tracts, Text PolA1699).

Enquiry: An Enquiry into the Causes of the Miscarriage of the Scots Colony at Darian: or an Answer to a Libel Entitled A Defense of the Scots Abdicating Darien (Glasgow 1700), EEBO: attr. Ridpath, George.

Paterson, William (1701): "A Proposal to Plant a Colony in Darien”, in: The Writings of William Paterson, Vol. 1, ed. Saxe Bannister, London 1859.

Pill: Pill for Pork Eaters, or, A Scots Lancet for an English Swelling, 1705.

The Golden Island or the Darian Song, By a Lady of Honour, Edinburgh 1699 .

View: A Short and Impartial View, signed P.C., 1699, EEBO: attrib. Andrew Fletcher.

Vindication: A Just and Modest Vindication of the Scots Design, for the Having Established a Colony at Darien with a brief display, how much it is their interest to apply themselves to trade, and particularly to that which is foreign, 1699 , EEBO: attrib. Robert Ferguson?. 


\section{Secondary Literature}

Ahrens, Rüdiger (1991): “The political pamphlet: 1660-1714. Pre- and post-revolutionary aspects”, in: Anglia 109, 21-43.

Alston, R. C. (1981): “The Eighteenth-century non-book: Observations on printed ephemera”, in: Barber, Giles/Fabian, Bernhard (eds.): Buch und Buchhandel in Europa im 18. Jahrhundert, Hamburg, 343-353.

Bös, Birte (2007): “'What do you lacke? what is it you buy?' Early Modern English service encounters”, in: Fitzmaurice, Susan/Taavitsainen, Irma (eds.): Methods in Historical Pragmatics, Berlin, 219-240.

Bowie, Karin (2007): Scottish Public Opinion and the Anglo-Scottish Union, 1699-1707, Woodbridge.

Claridge, Claudia (2000): "Pamphlets and Early Newspapers: Political Interaction vs. News Reporting”, in: Ungerer, Friedrich (ed.): English Media Texts - Past and Present. Language and Textual Structure, Amsterdam, 25-43.

Davies, Norman (1999): The Isles. A History, London.

Dossena, Marina (2003): "Modality and Argumentative Discourse in the Darién Pamphlets”, in: Dossena, Marina/Jones, Charles (eds.): Insights into Late Modern English, Bern, 283-310.

Dossena, Marina (2006): "Forms of Verbal Agression and Argumentation in the Darién Pamphlets”, in: Brownlees, Nicholas (ed.): News Discourse in Early Modern Britain, Bern, 235-254.

Fairclough, Norman (2009): Critical Discourse Analysis, $2^{\text {nd }}$ ed., London.

Gallup-Diaz, Ignacio (2002): The Door of the Seas and Key to the Universe: Indian Politics and Imperial Rivalry in the Darién, 1640-1750. Columbia University Press \& American Historical Association: Gutenberg-e. URL: www.gutenberg-e.org/gdio1/main.html

Partington, Alan (2008): “The armchair and the machine: Computerassisted discourse research", in: Taylor Torsello, Carol/Ackerley, Katherine/Castello, Erik/Aston, Guy (eds.): Corpora for University Language Teachers, Bern, 95-118.

Pratt Insh, George (1924): Papers Relating to the Ships and Voyages of the Company of Scotland Trading to Africa and the Indies, 1696-1707, Edinburgh.

Prebble, John (1968): Darién: The Scottish Dream of Empire, Edinburgh.

Prentice, Sheryl/Hardie, Andrew (2009): “Empowerment and disempowerment in the Glencairn Uprising. A corpus-based critical analysis of 
Early Modern English news discourse", in: Journal of Historical Pragmatics 10 (1), 23-55.

Smith, Nigel (1994): Literature and Revolution in England, 1640-1660, New Haven-London.

Sommerville, John (1996): The News Revolution in England. Cultural DYnamics of Daily Information, New York-Oxford.

van Dijk, Teun (1991): Racism and the Press, London. 


\section{Fragments as Failed Texts}

Conceptual Problems in Thomas More's

History of King Richard III and Percy Bysshe Shelley's

A Philosophical View of Reform

Jens Martin Gurr

I have deserted the odorous gardens of literature to journey across the great sandy desert of Politics; not, you may imagine, without the hope of finding some enchanted paradise. In all probability, I shall be overwhelmed by one of the tempestuous columns which are forever traversing with the speed of a storm and the confusion of chaos that pathless wilderness.

(Shelley on A Philosophical View of Reform, November 1819¹)

\section{Introduction: Unintended Fragments}

Had this volume followed the Hollywood logic of "start with an earthquake, then steadily escalate", this contribution would not have survived the editing process: There is no major fire here, no shipwreck, no spectacular bankruptcy, no dramatically failed enterprise; there is not even any material damage. In the context of this volume, the type of failure this essay considers - unintended fragments as 'failed' texts - may seem rather unspectacular. Looking at the reception history and the critical fortunes of the two texts to be discussed here, one might even speak of resounding successes. We will thus also have to address the question of what constitutes 'failure' and who makes the diagnosis - and at what point in time.

1 | Letter to J. \& M. Gisborne, 6 Nov. 1819. 
My two texts, Thomas More's History of King Richard III and Percy Bysshe Shelley's A Philosophical View of Reform, date from the very beginning and the very end of the Early Modern Period in England. More's History, written in the 1510s, but only published posthumously in the 1540 s, despite its fragmentary status quickly came to be celebrated as the founding text of English Humanist historiography. It is concerned with Richard's short reign (1483-1485) and thus with the end of the War of the Roses -1485 and the beginning of the Tudor line probably being the most compelling choice if one wanted to date the beginning of the Early Modern Period in England. Shelley's Philosophical View of Reform, written in $1819 / 1820$, but only published in 1920 , despite its incomplete nature, is frequently hailed as "the most advanced work of political theory of the age". ${ }^{2}$ It outlines Shelley's view of the political situation in England in the post-Napoleonic period and specifically discusses the necessary reforms and possible means of achieving them.

Texts thus abandoned for no obvious external reasons by their authors long before their deaths call for an explanation: I will argue that both of these texts had to remain fragments because of central inconsistencies and conceptual problems, fundamental aporias in the argument, which did not allow for completion and which, it seems, only occurred to the authors in the process of composition and forced them to break off.

These are not, to be sure, the only such texts in the Early Modern Period (or any period ${ }^{3}$ ): In English or German literature, one might equally have discussed Gottfried August Bürger's essay Die Republik England of $1792 / 1793^{4}$ or Wordsworth's The Recluse ${ }^{5}$ as cases in which there are no

2 | Cameron (1974), 149.

3 | A medieval example one might cite here would be Gottfried's Tristan, which breaks off after Tristan's love affair with the second Isolde, Isolde Weißhand. It has been argued that this infidelity of Tristan's was incompatible with the idea of the one fateful love between Tristan and the first Isolde and that this clash between the progression of the narrative as suggested by Gottfried's sources and the ideology and notion of love expounded in his work may have prompted him to break off. For this, cf. the summary discussion of previous assessments in the commentary to the edition of Gottfried von Straßburg (1995), vol. III, 269-274.

4 | For Bürger's “Die Republik England”, cf. Gurr (2007), 239-256 as well as Gassenmeier (1994), 43-79.

5 | For The Recluse as an unintended fragment, cf. Gurr (2003), 153-172. 
authorial comments accounting for the fragmentary status of a text; as a classic case in which an author himself formulates a statement of capitulation or at least utters reservations about his own design, one might refer to Kleist's remarks about his abandoned Guiskard tragedy. ${ }^{6}$

Thus, what I am not concerned with here are texts that have only come down to us as fragments, such as a number of classical Greek tragedies. I also disregard works that remained fragments simply because the author died before completion or for other such obvious external reasons. Finally, I am not concerned with the deliberately fragmentary texts of, say, German Romanticism, hence with the fragment as an aesthetic strategy and poetological concept. $^{7}$

Both my examples are manifestly not cases of 'somehow not quite getting it right' in the sense of Hershel Parker's thoughts on consistency and intended meanings:

Writers repeatedly fail to achieve their intended meanings during the actual creative process, even though their control over the emerging work is then at its strongest. [...] [F]laws which result from shifting or imperfectly realized intentions commonly survive in the printed text in the form of 'contrary details' which we override in our compulsion to make sense of what we read. $(768)^{8}$

Although there seems to be an urge even among theoretically enlightened critics to assume that such things just do not happen to major writers, the cases I am concerned with here are not ones of "contrary details", but rather ones of fundamental problems of consistency. Let us, as it were, attempt to look over the authors' shoulders, tracing the construction and argument of these texts and surgically extracting the central ruptures that may plausibly have led to their status as fragments.

6 | Cf. for instance the rich documentation in the following editions: von Kleist (2000), and von Kleist (2011).

7 | For an excellent comparative discussion of the fragment as an aesthetic strategy in German and English Romanticism, cf. Schmitt (2005).

8 | Parker (1983), 767-774. 


\section{Thomas More's History Of KING RICHARd III}

I begin with a reading of Thomas More's History of King Richard III which may be able to contribute to the controversy over why More chose to discontinue work on this text at least 15 years before his death in 1535. Various contemporary sources show that he was simultaneously working on a Latin and an English version around the years 1513-1515. ${ }^{9}$ In this work - essentially the founding text of English Humanist historiography and incidentally Shakespeare's major source for Richard III ${ }^{10}-$, More briefly outlines the background history with the War of the Roses as well as the reign of Edward IV and mainly covers the usurpation of Richard III in 1483 , only proleptically mentioning the battle of Bosworth in 1485 , when the Earl of Richmond defeated him and became King Henry VII, the first Tudor monarch.

Throughout the text, artfully constructed contrasts between key figures, invented highly ornate speeches and clearly moralizing passages of authorial comment and evaluation clearly point to More's didactic intent. 'Truthful' and 'accurate' historiography - problematic as those terms are anyway - is not the purpose here ${ }^{11}$ : What is important is the contrast More elaborates between Edward IV and Richard III and the question whether he believes in Richard's death as the end of tyranny and insecurity.

More consistently judges and evaluates the central characters and comments on their actions and moral positions. Thus, in the didactically

9 | For the genesis and editorial history of the work, cf. the standard edition by Sylvester (1963); for a more recent account of the textual history and More's numerous revisions, cf. Hanham (2007).

10 | For a comparative reading of More's and Shakespeare's Richard III, cf. also Gurr (1997), 51-78, where I also discuss in more detail a number of previous attempts to explain the fragmentary status of the History. This section of the present essay is to a considerable extent based on my earlier, more detailed reading of More's History.

11 Rather, the didactic exaggerations and the recreated, even fictitious speeches etc. are entirely obvious and deliberate characteristics of this form of fictionalized historiography. The genre of humanist historiography does not even claim historical veracity and accuracy in all details in the first place. For the generic conventions, cf. Heinrich (1987). 
styled repertoire of key figures, Richard's predecessor Edward IV is unambiguously heralded as the archetypal Renaissance king:

He was a goodly parsonage, and very Princely to behold, of hearte couragious, politique in counsaile, in aduersitie nothinge abashed, in prosperitie rather ioyfull then prowde, in peace iust and mercifull, in warre, sharpe and fyerce, bolde and hardye, and nathelesse no farther then wysedome woulde, aduenturouse.[...] In whych time of his latter daies, thys Realm was in quyet and prosperous estate: no feare of outewarde enemyes, no warre in hande, nor none towarde, but such as no manne looked for; the people towarde the Prynce, not in a constrayned feare, but in a wyllynge and louynge obedyence: amonge them selfe, the commons in good peace. $(4)^{12}$

The description of Edward as the ideal Christian king endowed with all physical, intellectual and moral qualities becoming the ideal ruler who, in his later years, commanded a peaceful and prosperous realm serves as a foil against which the allegedly tyrannous Richard is all the more decisively contrasted. This explains the obvious exaggerations and stylisations. For just as he sings Edward's praises, he unequivocally maligns Richard and condemns his cruelty: "Now fell ther mischieues thick. And as the thinge euill gotten is neuer well kept: through all the time of his reygne, never ceased there cruel death \& slaughter, till his owne destruccion ended it." (67f.).

More makes very little of the background of the War of the Roses; Richard's murder of King Henry VI is merely given as a rumour; Queen Margaret is not mentioned at all; and the only references to the conflicts between Henry VI and Edward IV are marginal $(6,65)$. The presentation of a moral example far removed from the concrete case at hand is the main concern here. It is sufficient to More's purpose to show a realm in peace and prosperity in which, upon the death of Edward the model king, a cruel tyrant eliminates all opposition, usurps the throne and plunges the realm into disaster. The general impression is that of an episode of anarchy and tyranny under a cruel and corrupt usurper portrayed in the worst possible light; an episode of anarchy and tyranny, however, in an otherwise well-or-

12 | More (1963). All references with page numbers indicated parenthetically in the text will be to this edition. 
dered, even exemplary state, and an episode that ends with " $\mathrm{y}^{\mathrm{e}}$ beste death, and $\mathrm{y}^{\mathrm{e}}$ most righteous" $(82) .{ }^{13}$

Richard is constantly maligned by contrasting him with opponents of morally, intellectually and politically unquestionable stature. Examples might be Queen Elizabeth who, in vigorous, even touching discussions struggles to have her children securely lodged out of Richard's reach, who tries to keep them isolated so he can have them murdered more easily (35f.). Or take Bishop Morton, portrayed as an ideal politician combining political can-do energy and effective diplomatic skills with firm moral principles: "The bishop was a man of gret natural wit, very well lerned, \& honorable in behaueor, lacking no wise waies to win fauor." (90).

Richard's predecessors and opponents are thus all portrayed in the most favourable light, which - together with a number of explicit references to the course of history - affords an understanding of More's view of history. ${ }^{14}$ According to this essentially optimistic, almost, one is tempted to say, eschatological view, the episode of tyranny must end with the usurper's death and the restoration of order. And although the text breaks off before the chronological account has reached the battle of Bosworth and Richard's end, More is unambiguous about Richard's fate, as several anticipatory comments make clear: "King Richarde himselfe as ye shall hereafter here, slain in the fielde, hacked and hewed of his enemies handes, haryed on horsebacke dead, his here in despite torn and togged lyke a cur dogge." (87).

Here, shortly before his account breaks off, More points to the didactic purpose of the History:

13 | Given the number and force of such fairly straightforward judgements, several recent critics overstate their diagnosis of More's history as "a deeply unstable text. There are, for example, frequent narrative disruptions; noticeable inconsistencies in More's descriptions of his characters; a fluctuating attitude toward textual sources; and a chronology that is almost never correct", as Dan Breen approvingly summarizes this line of thought; cf. Breen (2010), 466. Though these features undoubtedly exist, I find somewhat misleading and deconstructively over-ingenious the tradition of reading More's work as an inherently self-deconstructive text foregrounding constant doubts about its own reliability.

14 | For More's view of history, cf. also Heinrich (1987), 17 et passim. 
Which thinges on euery part wel pondered: god neuer gaue this world a more notable example, neither in what vnsuretie standeth this worldly wel, or what mischief worketh the prowde enterprise of a hyghe heart, or finally what wretched end ensueth such dispiteous crueltie. (86)

His work is meant to elaborate three lessons: (1) "in what vnsuretie standeth this worldly wel”, most clearly exemplified in Hastings' sudden downfall; (2) "what mischief worketh the prowde enterprise of a hyghe heart", which is sufficiently illustrated by all the evil committed during Richard's reign; (3) "what wretched end ensueth such dispiteous crueltie", which points to Richard's fate described a few lines later. All three teachings have sufficiently been dealt with up to this point in the History; a continuation of More's account could have added names, dates or events, but could hardly have added anything to his purpose.

While More is thus perfectly explicit about Richard's fate, it is interesting to note that he does not mention Richmond - later Henry VII - as the noble prince rightfully ending Richard's tyrannous reign or refer to him as the military leader who won the decisive battle against Richard at Bosworth; he merely speaks of "his enemies" (87). But given More's opinion about Henry as expressed elsewhere, it is no longer surprising that he should fail to cast him in the role of liberator. For in More's Latin epigrams on the coronation of Henry VIII, the reign of the young king's father Henry VII is described as a period of "slavery" and "sadness", with "laws heretofore powerless - yes, even laws put to unjust ends."

A further revealing view of More's attitude towards Henry VII is afforded by the story of his opposition as a young MP to Henry's demand that parliament grant him $£ 90,000$ for the marriage of his daughter Margaret to James IV of Scotland (1504). More successfully argued against this claim on the grounds that this was an unbearable sum for the citizens to pay. When Henry learned that "a beardless boy" had opposed his plans, he

15 | The Latin Epigrams of Thomas More (1953), 16: "Meta haec seruitii est" (I. 5), "Tristitiae finis" (I. 6), “Leges inualidae prius, imo nocere coactae” (I. 25). Here, More hardly shows consideration or any fear of offending Henry VIII by criticizing his father. In their annotations Bradner and Lynch point out: "The new monarch, however, indicated by his impeachment and execution of his father's principal agents, Empson and Dudley, that he would not resent such comments", Bradner and Lynch, 143. 
is said to have arrested and incarcerated More's father. ${ }^{16}$ The authenticity of this anecdote given by William Roper is not entirely certain, but it is quoted by several scholars without substantial doubt; there appears to be no reason to disbelieve More's son-in-law.

Richmond thus never features as the noble prince who - according to the carefully elaborated didactic structure of the work - would have been needed to end the reign of terror under Richard and to lead the realm back to peace and prosperity. The only reference to Henry VII is ambiguous and most likely ironic: "Howbeit concerning $\mathrm{y}^{t}$ opinion, with the occasions mouing either partie, we shal haue place more at large to entreate, yf we hereafter happen to write the time of the late noble prince of famous memory king Henry y seuenth." (82f.). In the light of More's view of Henry VII expressed elsewhere, this is almost certainly mere sarcasm. Firstly, the distanced and casual "yf we hereafter happen to write" does sound somewhat facile, suggesting an attitude of 'if, maybe, at some point, I do stoop to write about him'. Secondly, the reference to "the late noble prince" invokes the topos of de mortuis nihil nisi bene; More can thus elegantly imply criticism of Henry without having to elaborate. Thirdly, and most importantly, although it was also already used in its modern sense of 'wellknown', 'famous' in More's days was still closer to its Latin etymology of 'fama' and is therefore recorded to have meant something like 'notorious, ill-famed'. ${ }^{17}$

Viewed together, More's essentially optimistic view of history as expressed in this work, the reference to Richard's end as " $y^{\mathrm{e}}$ beste death, and $\mathrm{y}^{\mathrm{e}}$ most righteous" (82), ending an episode of tyranny, the clearly didactic purpose in contrasting Richard with his allegedly glorious predecessor Edward IV, and finally More's personal opposition to Henry VII and the devastating critique of his reign in the epigrams allow for a plausible hypothesis as to why More may have abandoned the History.

We have seen that his understanding of history as expressed in the History is essentially optimistic: The usurper who unlawfully breaks into an era of peace and prosperity is rightly disposed of. If More had completed his work, an explicit reference to Henry VII as his successor would have been inevitable; but to have the tyrant vanquished and succeeded by a king

16 | For this episode, cf. Roper (1557/1935), 9; quoted in Heinrich's edition (1984), 18ff.

17 | Cf. OED, entry 3 b. 
hardly better than Richard would not have been conducive to More's didactic purpose. A further tyrant would in fact have destroyed the carefully elaborated structure of the work; it would have ruined the didactic conception; it would have created the impression of a fundamentally corrupt state in which one tyrant succeeds another. More has exemplified in Edward IV the connection between the ethos of the king and the well-being of the realm; he has portrayed Richard as the counter-model of a usurper who plunges the state into disaster. More thus exemplifies political positions and different types of politicians. According to this representative structure of the text with Edward IV as the model king and with Richard as the archetypal tyrant ${ }^{18}$, there was simply no room for a further tyrant of Henry's calibre. It seems plausible that the incompatibility of Henry VII with the contrastive approach of his History occurred to More only in the process of writing; the way it was begun, the work could not be finished without great internal incongruities or without blatant falsification of history against the author's commonly known views. This, it seems, accounts better for the fragment status of the History than the explanations previously given. ${ }^{19}$

18 | For a detailed analysis of More's use of individual characters as paradigms of basic political positions, cf. Heinrich (1987), 94ff.

19 | Fox adduces two possible reasons, (1): "It is possible that More failed to complete the History because a more urgent preoccupation intervened, in this case perhaps the need to answer Luther's Contra Henricum in 1522"; (2): "Possibly the judicial murder of the third Duke of Buckingham in 1521 shocked More into recognizing that the history of King Richard III was beginning to be rewritten in his own time [under Henry VIII]" (Fox. Thomas More: History and Providence, 1982, 105, quoted in Heinrich (1987), 16f., cf. also Breen (2010), 467). Both suggestions, however, bring about a need to argue for a time of composition after 1521 , which runs counter to an almost unanimous consensus about a terminus ante quem of 1518 (cf. the tradition from More's nephew William Rastell all the way to Sylvester's standard 1963 edition with its persuasive arguments in favour of that dating. Logan has suggested a further reason: "He may also have become convinced that he could never publish the History ... a number of powerful men [or their fathers] had played questionable parts in the events he was recounting." Logan, "Introduction", More (2005), xv-Iviii, xli. Finally, again mainly referring to Fox's work, Breen summarizes as follows a somewhat deconstructive account: "More's History had to end before it was in fact complete because the narrative 
If, from a production perspective, we thus regard the History as a failed text, contemporaneous literary theory raises intriguing questions about auctoritas, authorship and the origins of 'failure' or 'success': On the one hand, Kevin Dunn refers to "authorship" as "an institution that in its fullest form is coterminous with humanism" (9f.) and even argues for humanism as the period "of the fullest exercise of self-authorizing rhetoric in the Western literary tradition before the Romantics". ${ }^{20}$ On the other hand, if, according to the doctrine of inspiration, "God is the source of human creativity [...] [w]ho, then, can claim the rights of authorship over any text?" 21 - and who can be said to 'fail' if an author fails to complete a text? Contemporary notions of auctoritas, it seems, do not permit a discussion of 'failure'. What is more, the reception of More's text made sure such questions did not need to be raised: Within a few decades, it came to be regarded as an exemplary achievement. Roger Ascham's endorsement is illuminating in more than one respect:

Diligence also must be used in [...] describing lively, both the site of places and nature of persons, not only for the outward shape of the body, but also for the inward disposition of the mind, as Thucydides doth in many places very trimly, and Homer every where [...] and our Chaucer doth the same, very praise-worthily. [...] Sir Thomas More, in that pamphlet of Richard the Third, doth in most part, I believe, of all these points so content all men, as if the rest of our story of England were so done, we might well compare with France, or Italy, or Germany, in that behalf. ${ }^{22}$

represents an encroaching realization of the inadequacy of rhetoric as an agent capable of generating a convincing psychological verisimilitude based solely on accounts provided by other historical texts", cf. Breen (2010), 475f.; the reference is to Fox (1989), 125 et passim. This reading, I would argue, entirely overrides the dominant sense of remarkably assured assessments and evaluations and vastly overstates the text's disclaimers and hedging expressions in order to stress its "instability".

20 | Cf. Dunn (1994). For the complex relations between authorship and authority in the period in question, cf. also Miller (1986), esp. 3-8; cf. also Hampton (1990).

21 | Miller (1986), 138. For the issue of human vs. divine creation, cf. Miller (1986), 136-139 as well as Guillory (1983).

22 | Ascham, qtd. in: Höfele (2005), $192 f$. 
Firstly, by placing More's History side by side with Homer, Thucydides and Chaucer, this assessment sheds interesting light on the contemporary understanding of the genre of historiography and its conflation with what we would call 'fiction'. Secondly, More's auctoritas, his “reputation as a scholar, saint and martyr helped [the History] to form the prevailing view of Richard for the following two centuries". ${ }^{23}$ The incomplete status of the history does not appear to have been an issue at all and certainly did not prevent it from quickly becoming the one model to anyone "to be looked for at his hand that would well and advisedly write an history"24 as Ascham further commended it.

\section{Shelley's A Philosophical View of Reform}

My second fragment is Shelley's treatise A Philosophical View of Reform, written in 1819 after the Peterloo Massacre. On 16 August 1819, brutal intervention of the military killed 11 people and wounded about 500 when some 60,000 people assembled in Manchester peacefully to protest in favour of parliamentary reform. Upon hearing of this massacre in his Italian exile, Shelley began his essay, in which, after an overview of the development of liberty in world history since ancient Greece, he discusses the need for political and social reform in Britain, outlines a number of the necessary reforms and attempts to chart a likely path to achieving them. Shelley abandoned the essay at some point early in 1820 and it was only published posthumously as late as $1920 .^{25}$

Desmond King-Hele speaks for many critics of the essay when he calls A Philosophical View of Reform "the last and best of Shelley's political utterances". ${ }^{26}$ Several commentators have even spoken of it as "the most

23 | Hammond (1993), 139.

24 | Ascham, qtd. in Höfele (2005), 191.

25 | Cf. the documentation of composition and publication history in the following edition: Shelley (1965), 3-55. All references with page numbers indicated parenthetically in the text will be to this edition.

26 | King-Hele (1984), 143. Cameron (1973), 10, argues that "[h]is general views on these matters, his social philosophy, received their most complete expression in his long prose work, A Philosophical View of Reform"; Cantor (1997), 22, speaks 
advanced work of political theory of the age" ${ }^{27}$ Nonetheless, it seems that the success of Shelley's essay and the corresponding poems of 1819 , which have been influential texts in the history of European socialism, may have made many critics overlook or gloss over the key conceptual problems they pose. ${ }^{28}$ An analysis of the structure of Shelley's argument will show that the text has reached a shattering argumentative impasse at just the point at which it breaks off, a fundamental conceptual problem that is quite sufficient to explain why the text had to remain a fragment.

Let us turn to an overview of the text itself and of the problems it proposes to solve. In the "Introduction", the first of three sections, Shelley gives an overview of the development of liberty in world history from Greece to the England of his own time; in the chapter entitled "On the sentiment of the Necessity of change", he argues the need for change in British society and makes a good number of very reasonable proposals such as enlarging the suffrage, abolishing tithes, parliamentary reform, reducing the national debt, freedom of religion etc. Difficulties only arise in the section entitled "Probable Means", in which Shelley discusses how these reforms are to be achieved. Here, he uneasily hovers between a call for passive resistance and a realization that revolutionary violence may be necessary.

Throughout the essay, there are passages which seem filled with high hopes for imminent change: "The literature of England, an energetic development of which has ever followed or preceded a great and free develop-

of it as the "one text among all of Shelley's writings [...] central to any examination of his political and economic views".

27 | Cameron (1974), 149; Cantor (1997), 42, calls it "the most significant and substantive essay on economic matters produced by any of the English Romantics." Cf. also Hoagwood (1988), 209, and Foot (1984), 180 et passim. Numerous further scholars might be quoted here with similar assessments.

28 I It is plausible, of course, to argue that some of the ambivalence in the Reform essay may be due to Shelley's attempt to harmonize the demands of moderate reformers such as Burdett and Leigh Hunt rallied round Hunt's Examiner with those of the radicals Henry Hunt, Cartwright, Cobbett etc. with Cobbett's Register as their organ. He knew that reform was only possible if reform forces did not neutralize and obstruct each other. But this is hardly enough to account for the key conceptual problems of the treatise. 
ment of the national will, has arisen, as it were, from a new birth." (19). ${ }^{29}$ It is in a similarly optimistic vein that Shelley repeatedly calls for passive resistance in the hope that the tyrants will not be able to uphold for long a system of oppression in the face of a passively resisting multitude prepared to "receive with unshrinking bosoms the bayonets of the charging battalions":

[I]f the tyrants command their troops to fire upon them or cut them down unless they disperse, [the true patriot] will exhort them peaceably to risque the danger, and to expect without resistance the onset of the cavalry, and wait with folded arms the event of the fire of the artillery and receive with unshrinking bosoms the bayonets of the charging battalions. [...] the soldiers are men and Englishmen, and it is not to be believed that they would massacre an unresisting multitude of their countrymen drawn up in unarmed array before them [...] (48f.)

This is the tone and tenor predominant in much of the Reform essay. But despite the high hopes, there are passages in which Shelley comes to realize that peaceful passive resistance may no longer be an option:

It is possible that the period of conciliation is past, and that after having played with the confidence and cheated the expectations of the people, their passions will be too little under discipline to allow them to wait the slow, gradual and certain operation of such a Reform as we can imagine the constituted authorities to concede. (46)

Reform, it seems, may no longer be possible. And after the somewhat stubborn and logically inconsequential assertion that "[i]f the Houses of Parliament obstinately and perpetually refuse to concede any reform to the people, my vote is for universal suffrage and equal representation" (47), Shelley launches into a tortuous line of reasoning that ultimately leads him to the realization that violent "struggle must ensue":

If the Houses of Parliament obstinately and perpetually refuse to concede any reform to the people, my vote is for universal suffrage and equal representation. My

29 | Cf. also the Preface to The Revolt of Islam, where Shelley writes that "[m]ankind appear to me to be emerging from their trance. I am aware, methinks, of a slow, gradual, silent change". Shelley (1970), 34. 
vote is-but, it is asked, how shall this be accomplished [...]? This question I would answer by another. [...] When the majority in any nation arrive at a conviction that it is their duty and their interest to divest the minority of a power employed to their disadvantage; and the minority are sufficiently mistaken as to believe that their superiority is tenable, a struggle must ensue. (47)

While, in a number of passages throughout the essay, he maintains that non-violent protest is the appropriate and promising means to achieve the necessary reforms, he here acknowledges that this is no longer an option under the prevailing political circumstances. The clearest recognition that revolutionary violence is inevitable, however, occurs in the following brief passage: "For so dear is power that the tyrants themselves neither then, nor now, nor ever, left or leave a path to freedom but through their own blood." (6). But even advocacy of revolutionary violence is recognized to be an untenable position. For reforms achieved by means of violence are only attained at the price of their immediate self-cancellation; they cannot be made to last. If the republic Shelley hopes for and is trying to promote is brought about by means of violence, it risks being an unstable one destined for failure: "A Republic, however just in its principle and glorious in its object, would through violence and sudden change which must attend it, incur a great risk of being as rapid in its decline as in its growth." (41).

What lies behind Shelley's hovering between passive resistance and the call for revolution, more precisely, what lies behind his quick insistence that revolution cannot responsibly be claimed as an option, is a profound despair in view of an anthropological scepticism that is uncomfortably hinted at throughout the essay: Shelley apparently came to believe that the masses where neither prepared nor able to carry out a revolution: But there is an even more problematic thought behind it: the masses clearly would not be able even to handle the liberty they might achieve. This is Shelley again, arguing by historical analogy - here with the English Revolution of the mid-17th century and the French Revolution - that a revolution would lead to uncontrollable violence and could not be a means of achieving the desired liberties: "The authors of both [the English and the French] Revolutions proposed a greater and more glorious object than the degraded passions of their countrymen permitted them to attain." (15). Similarly, he argues that "the poor [...] by means of that degraded condition [...] are sufficiently incapable of discerning their own genuine and permanent advantage [...]" (21). This is of course a timeless dilemma: In the context 
of the English Revolution, it occupied and tormented Milton; during the French Revolution, a similar anthropological scepticism prompted Wordsworth and Coleridge to recant their early enthusiasm for the Revolution and made them turn to Burkean conservatism. ${ }^{30}$

It becomes painfully clear in the course of Shelley's treatise that this hovering between a call for passive resistance throughout the better part of the text and the acknowledgement that violence may be inevitable cannot be an ingenious double strategy, superficially claiming to warn the masses against violence while obliquely showing it to be the only solution. Rather, it is the result of a fundamental anthropological and political problem that may well have been impossible to solve under the prevailing conditions: Shelley must have come to understand that neither passive resistance nor violence were possible means of bringing about the desired reforms. ${ }^{31}$

This dilemma of not knowing how to counter oppression, whether by means of passive resistance or by means of revolutionary violence, also occurs in Shelley's poetry written at around the same time. It may, for example, be illustrated by quoting from “The Masque of Anarchy” written at exactly the same time. In a very similar way, Shelley here also hovers between passive resistance and revolutionary violence:

And if then the tyrants dare

Let them ride among you there,

Slash, and stab, and maim, and hew,-

What they like, that let them do.

(II. 340-43, stanza 84)

This closely echoes the call to "receive with unshrinking bosoms the bayonets of the charging battalions" (48) from the Reform treatise; but the acknowledgement we saw in the essay that violent insurrection may be necessary is also present in this versified form of the essay. There is a

30 | For this dilemma, cf. the chapters on Milton and Wordsworth in Gurr (2003).

31 A letter written nine days before his death in its resigned and defeatist note supports my reading: "England appears to be in a desperate condition [...] I once thought to study these affairs \& write or act in them-I am glad that my good genius said refrain. I see little public virtue, \& I foresee that the contest will be one of blood \& gold [...]", letter to Horace Smith, 29 Jun. 1822; Letters, II, 442. 
strong revolutionary impetus here in the call to cast off the chains of oppression and in the insistence that the tyrants are outnumbered by their hitherto submissive subjects now awakening to their own potential power:

\author{
Rise like Lions after slumber \\ In unvanquishable number- \\ Shake your chains to earth like dew \\ Which in sleep had fallen on you- \\ Ye are many-they are few. \\ (II. 151-55, stanza 38; repeated as the concluding stanza 91, II. 368-72)
}

Arguing that this is "scarcely the best slogan for promoting the stoic virtues of passive resistance", Desmond King-Hele ${ }^{32}$ voices the discomfort many critics have felt about the consistency of these great final lines with the doctrine of passive resistance Shelley expounds elsewhere in the poem. But this mere uneasiness seems to me considerably to underestimate the extent to which the poem in wonderfully persuasive fashion trumpets two entirely irreconcilable ideas at the same time. These lines, having occurred first at a crucial point as stanza 38 of the text, are repeated in a singularly charged context at the very end of the poem - can they be understood as anything but a very clear call for revolutionary violence? Further evidence of Shelley's tendency to advocate violent rebellion is evident in several poems written around 1819. In "An Ode Written October, 1819", he speaks of the struggle against oppression as "holy combat" (1. 14); and in the "Song to the Men of England" (1819), he urges: "Forge arms, - in your defence to bear” (1. 24).

Given this ambivalence about possible means of attaining the desired reforms, and given the fact that there is no solution in the essay, let us look at what solutions to the dilemma Shelley offers in the poetry: In "The Masque of Anarchy", despite the contradictory impulses sketched above, the liberation from oppression is brought about by "Hope, that maiden

32 | King-Hele (1984), 148; Cameron (1974), 350, argues about the concluding stanzas of The Masque of Anarchy: "the passage is, in effect, revolutionary without any suggestion of passivity". Cf. also Foot 1984, passim and "Introduction". Foot quite clearly points to the clash between irreconcilable positions in the poem. On the latent contradictions in Shelley's poetry of the same time, cf. also Behrendt (1993), 129f. (on “Song to the Men of England”, 1819). 
most serene" (1. 128; stanza 32), who flings herself heroically in front of the apocalyptic riders of oppression, whereupon they die or disappear - hardly a means of reform one would confidently hope for. And in the "Ode to Liberty" of 1820 , who overthrows tyrants all over the world? Well, Liberty, with a capital L, Liberty personified:

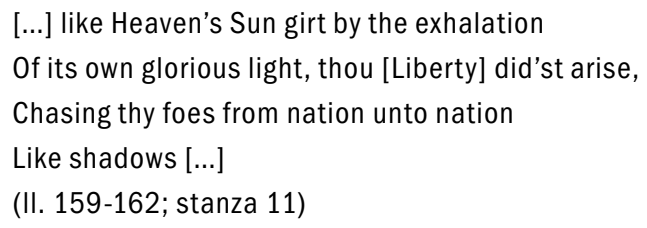

And, again, it is only in poetry that the overthrowing of oppression, the breaking of "Spain's links of steel" can be delegated to "virtue's keenest file": "but Spain's were links of steel,/Till bit to dust by virtue's keenest file" (11. 19of.; stanza 13). And in Prometheus Unbound, it is again an impersonal abstraction, Demogorgon, who overthrows Zeus, the archetypal tyrant.

It is largely through these grand abstractions, I believe, that poems such as "Masque of Anarchy" come across as powerful assertions of political liberty and are still read as great and mature satirical poems and serious contributions to a political debate. This magnificent poetic grandiloquence allows Shelley vaguely to gloss over just that fundamental question of how reform and liberty are to be achieved; the poetic form can sustain such ambiguities; the discursive form of the treatise cannot, even though it is virtually an expository and reasoned version of the contemporaneous poems. Thus, Cantor's assessment of the relationship between the Reform essay and the accompanying poems, persuasive as it may seem, is rather too simple: "Shelley's poetry inspires us to make life better; prose works, like A Philosophical View of Reform, show us how it can actually be done." ${ }^{33}$ Similarly, the reading of the Reform essay in the authoritative 2013 Oxford Handbook of Percy Bysshe Shelley, which summarizes the dominant view, seems entirely to overlook the torturously conflicted, ultimately aporetic nature of Shelley's argumentative endeavour: "The plan of action is prac-

33 | Cantor (1997), 38. Such assumptions of a fairly straightforward and unproblematic relationship between Shelley's poetry and prose of this time are common. For a comparable view of the relationship, cf. Hogle (1988), 223. 
ticable, reasonable, plausible, and unyielding in trying to move society toward radical reform." ${ }^{34}$

Let us turn to the essay again to see how that central aporia forces Shelley to break off at a crucial moment. What Shelley has unwillingly succeeded in making painfully clear in a number of laborious and conflictive argumentative circles in the essay and in the obvious contradictions and evasions in the poetry of the same time is that, first, he sees no hope for gradual and peaceful reform. Secondly, he seems to have come to understand that revolutionary violence is inevitable. But he has made it equally clear that a revolution could only bring about its own decline and could only end in disaster. There is, Shelley has shown at this point in the essay, no solution, for there is no responsible or even feasible means of achieving and securing the desired liberties.

It is virtually on the last page of the essay that this dilemma once more becomes glaringly obvious. This is Shelley again, without any abbreviations or omissions on my part. The hyphen ending in the void and the anguished omission mark of the three dots are all original:

These brief considerations suffice to show that the true friend of mankind and of his country would hesitate before he recommended measures which tend to bring down so heavy a calamity as war-

I imagine however that before the English Nation shall arrive at that point of moral and political degradation now occupied by the Chinese, it will be necessary to appeal to an exertion of physical strength. If the madness of parties admits no other mode of determining the question at issue, ...

When the people shall have obtained, by whatever means, the victory over their oppressors and when persons appointed by them shall have taken their seats in the Representative Assembly of the nation, and assumed control of public affairs according to constitutional rules, there will remain the great task of accommodating all that can be preserved of antient forms with the improvements of the knowledge of a more enlightened age, in legislation, jurisprudence, government and religious and academical institutions. (54; omission marks original) ${ }^{35}$

34 | Scrivener (2013), 172.

35 | David Duff draws attention to this dilemma in Shelley's thought in general and in the Reform treatise in particular: "This, as has often been pointed out, was a dilemma that Shelley never fully resolved. Even in A Philosophical View of Reform 
The solution to Shelley's fundamental question - how to achieve the necessary reforms - remains undiscovered; it lies in the three dots, after which Shelley happily goes to list all the wonderful changes to be made after "the people shall have obtained, by whatever means, the victory over their oppressors" (my italics). Here, in the section "Probable Means", the entire point of which is to delineate ways of achieving "the victory over their oppressors", the evasive "by whatever means" at this crucial moment is the ultimate admission of defeat. Half a page later, after another highly

(1819), his most considered treatment of the topic, he leaves a vacancy - literally a gap in the manuscript - at the crucial point at which he turns to the question of how the people are to obtain 'the victory over their oppressors' which will free them from 'moral and political degradation.'”, Duff (1994), 110. Foot (1984), 189, also remarks upon this gap in Shelley's text. Neither Duff nor Foot, it seems, recognize the centrality of this problem to Shelley's argument, and they certainly do not point it out as a potential reason for the fragmentary nature of the text. Cf. also Foot (1990), 5, where he argues that "the pamphlet is marked throughout with contradictions"; cf. also Cameron (1974), 350. But even Foot glosses over the central aporia in Shelley's argument: "the pamphlet breaks off, leaving two blank pages which Shelley obviously planned to fill in later, perhaps when he had more closely worked out the complex relationship between reform and revolution." Foot further obscures the fundamental problems in the essay when he writes: "The Philosophical View of Reform was ready for its reluctant publisher in 1820", Foot (1990), 7. Cf. also McNiece (1969), 90: "The first problem for Shelley, as for every other reformer, was how to persuade Parliament to reform itself when the membership of the House of Commons was for the most part dedicated to and profiting by the perpetuation of the old order." Interestingly, McNiece closely echoes Shelley's crucial crux apparently without recognizing it as a fundamental problem: "Once the people have won their cause, by whatever means, and have 'assumed the control of public affairs according to constitutional rules [...]'” (92). White similarly fails to see this central problem as a potential reason for Shelley to abandon the work: "In the incomplete nature of Shelley's essay it is impossible to state the steps by which these changes were to be realized.", White (1947), II, 147. White discusses A Philosophical View of Reform on pages 144-151. Dawson (1980), 5 et passim, also comments on this dilemma in Shelley's thoughts and quotes an enlightening passage from Hobsbawm's remarks on millenarian hopes: "millenarian movements share a fundamental vagueness about the actual way in which the new society will be brought about", Hobsbawm (1971), $57 \mathrm{f}$. 
significant reflection on the tendency for bloody revenge in the uneducated masses - another argument against revolution - the essay breaks off.

Rarely has the aporia of an argumentative endeavour stared one in the face more openly. It is hard to see why the landmark 2013 Oxford Handbook of Percy Bysshe Shelley remains so non-committal on this point: "Shelley for unknown reasons never carried the work to completion." (171). There is, it seems, no need to resort to external reasons to explain why the text had to remain incomplete. Fear of not finding a publisher for his essay, as the standard explanation has $i^{36}{ }^{36}$ can hardly have made him give up the project: many of Shelley's texts - including "The Masque of Anarchy" (only published in 1832) - remained unpublished in his lifetime. ${ }^{37}$

Let us finally consider a letter Shelley wrote to John and Maria Gisborne in November 1819 . The letter is usually only cited to date the beginning of Shelley's work on the Reform essay - but it is also an uncomfortable hint at potential problems in the endeavour he was undertaking. Shelley here presciently writes:

I have deserted the odorous gardens of literature to journey across the great sandy desert of Politics; not, you may imagine, without the hope of finding some

36 | Cf. for instance the "Editorial Notes" by Ingpen and Peck, VII, 332. Paul Foot writes about Shelley's failure to complete and to publish the essay and his attempt to get Hunt to publish it or to arrange publication for him: "He knew no one to turn to except Hunt, and Hunt was not amenable. Thus the collection was not published [...]", Foot (1990), 1. Cf. also ibid., 4: "[T]he deafening silence from Hunt [who failed to respond to his requests to arrange for publication of the essay] obliged him to abandon it." Cf. also Foot (1984), passim. In Shelley: The Golden Years, 128, Cameron writes: "Unfortunately, his failure to get a publisher discouraged him from continuing, and the work is unfinished." Some scholars also cite Shelley's letter to Ollier, 15 December 1819; Letters II, 164, in which he states that "now that I see the passion of party will postpone the great struggle till another year, I shall not trouble myself to finish [the Reform treatise] for this season." Cf. for instance Dawson (1980), 197. This is hardly compelling evidence, for as late as May 1820 he was still trying to have it published; cf. the much-quoted letter to Hunt of 26 May 1820, Letters, II, 201.

37 | A Philosophical View of Reform was first published by Oxford University Press in 1920, edited by T.W. Rolleston. For the history of Shelley's manuscript until 1920, cf. for example Peck (1924), 910-918. 
enchanted paradise. In all probability, I shall be overwhelmed by one of the tempestuous columns which are forever traversing with the speed of a storm \& the confusion of chaos that pathless wilderness. ${ }^{38}$

Pathless indeed. Should we not read this as an acknowledgement on Shelley's part that the task he had set himself was an impossible one? For the text in a fascinating way allows one to look over Shelley's shoulder, as it were, and to see him fail - if failure we want to call the sincere struggle to solve a problem that literally was impossible to solve responsibly under the prevailing circumstances. In the contemporary political and economic situation, under the repressive conditions in England in 1819/1820, culminating in the notorious "Six Acts" of December 1819, long before even the moderate reforms of the Reform Bill of 1832 appeared achievable, there could not be a political solution; it was unthinkable. The inability to formulate one was not Shelley's; it was inherent in the structure and the determinants of the political discourse in $1819 / 1820$.

\section{Conclusion: Literary History and the Definition of 'Failure'}

At the very beginning of the Early Modern Period in England, in the 1510s, one of the major writers of the age, Thomas More, is at work on a political biography, an "investigation of the English political system" (Breen 467), a study of political theory. A good 300 years later, in 1819 and thus by any definition at the very end of the Early Modern Period, one of the major writers of the age, Percy Bysshe Shelley, is at work on a synthesis of his political views, an investigation of the English political system, a study of political theory. Although writing under the influence of very different notions of authorship, both writers, it seems, ultimately abandon their texts and leave them fragments because of fundamental conceptual inconsistencies. Both texts remain unpublished during their authors' lifetimes. From the point of view of an aesthetics of production, it is plausible to see both The History of Richard III and A Philosophical View of Reform as cases of failure.

38 | “Letter to John and Maria Gisborne”, November 6 1819, Letters II, 150. 
However, The History of King Richard III, given its undoubted literary merits and the author's auctoritas, his "reputation as a scholar, saint and martyr" 39 , within decades of its composition came to be hailed as the model to anyone "to be looked for at his hand that would well and advisedly write an history"40 and quickly assumed the status of a celebrated text virtually founding the genre of humanist historiography in England. Rather more belatedly, first published exactly a century after its composition, Shelley's Reform essay, in its turn, came to be recognized as "the most advanced work of political theory of the age"41 and is now frequently regarded as "a wonderful inspiration to anyone who feels the same about [contemporary oppressive leaders] as Shelley felt about Lords Liverpool, Castlereagh, Sidmouth and Eldon". ${ }^{2}$ It may be important to note that, while Shelley's essay (as well as early scholarly work by Shelley's then few defenders $)^{43}$ was published at a time when his critical standing was far from secure ${ }^{44}$, broader interest in - and frequently sympathy with - the Reform essay and its clearly progressive politics only arose at a time when Shelley's role as a major Romantic poet and thinker had become virtually unassailable. Shelley's - frequently conservative - detractors, we may note, hardly engaged with the essay; that T.S. Eliot and others would - falsely, as I hope to have shown - have taken Shelley's hovering and evasiveness at key points of the essay as confirming his literary and intellectual immaturity is another matter.

In both More's and Shelley's cases, then, the fragmentary nature of the text hardly plays a role even in the majority of scholarly discussions. Judging by intellectual impact and by later critical as well as popular assessments, one will hardly want to count the History of King Richard III or A Philosophical View of Reform as failures. ${ }^{45}$

39 | Hammond (1993), 139.

40 | Ascham, 5ff., qtd in Höfele (2005), $192 \mathrm{f}$.

41 | Cameron (1974), 149.

42 | Foot (1990). This is Foot's 1990 popular edition of the Reform essay and the accompanying poetry of late 1819 ("Men of England" etc.).

43 | Cf. for instance Peck (1924).

44 | For a history of Shelley's reputation and especially his detractors in the early 20th century, cf. Reiman and Freistat (2002), 539-549.

45 | This essay reuses material from my earlier essays "Two 'Romantic' Fragments" and from “'Bad is the world'”. 


\section{References}

Behrendt, Stephen C. (1993): “The Exoteric Political Poems”, in: Michael O’Neill (ed.), Shelley, London, 122-139.

Breen, Dan (2010): “Thomas More's History of Richard III: Genre, Humanism, and Moral Education”, in: Studies in Philology 107.4, 465-492.

Cameron, Kenneth Neill (1973): "Percy Bysshe Shelley”, in: Kenneth Neill Cameron (ed.), Romantic Rebels: Essays on Shelley and his Circle, Cambridge, Mass., 1-17.

Cameron, Kenneth Neill (1974): Shelley: The Golden Years, Cambridge, Mass.

Cantor, Paul A. (1997): “The Poet as Economist: Shelley's Critique of Paper Money and the British National Debt”, in: Journal of Libertarian Studies 13.1, 21-44.

Dawson, P.M.S. (1980): The Unacknowledged Legislator: Shelley and Politics, Oxford.

Duff, David (1994): Romance and Revolution: Shelley and the Politics of a Genre, Cambridge.

Dunn, Kevin (1994): Pretexts of Authority: The Rhetoric of Authorship in the Renaissance Preface, Stanford.

Foot, Paul (1990): “Introduction”, in: Paul Foot, Shelley's Revolutionary Year: Shelley's Political Poems and the Essay 'A Philosophical View of Reform', ed. Paul Foot, London.

Foot, Paul (1984): Red Shelley, London.

Fox, Alistair (1989): Politics and Literature in the Reigns of Henry VII and Henry VIII. Oxford.

Fox, Alistair (1982): Thomas More: History and Providence, Oxford: Blackwell.

Gassenmeier, Michael (1994): “Gottfried August Bürgers Aufsatz 'Die Republik England”, in: Wolfgang Beutin \& Thomas Bütow (eds), Gottfried August Bürger (1747-1794): Beiträge der Tagung zu seinem 200. Todestag vom 7. bis 9. Juni in Bad Segeberg, Frankfurt a.M., 43-79.

Guillory, John (1983): Poetic Authority: Spenser, Milton, and Literary Histo$r y$, New York.

Gurr, Jens Martin (1997): “'Bad is the world and all will come to nought': History and Morality in More's and Shakespeare's Richard III”, in: Litteraria Pragensia 7, 51-78. 
Gurr, Jens Martin (2003): The Human Soul as Battleground: Variations on Dualism and the Self in English Literature, Heidelberg.

Gurr, Jens Martin (2007): “Two 'Romantic' Fragments?: Bürger and Shelley on Revolution”, in: Christoph Bode \& Sebastian Domsch (eds.), British and European Romanticisms: Selected Papers from the Munich Conference of the German Society for English Romanticism, Trier, 239256.

Hammond, Peter W. (1993): “The Reputation of Richard III,” in: John Gillingham (ed.), Richard III: A Medieval Kingship, New York, 133-149.

Hampton, Timothy (1990): Writing from History: The Rhetoric of Exemplarity in Renaissance Literature, Ithaca.

Hanham, Alison (2007): “The Texts of Thomas More's Richard III”, in: Renaissance Studies 21.1, 62-84.

Heinrich, Hans-Peter (1987): Sir Thomas Mores 'Geschichte König Richards III' im Lichte humanistischer Historiographie und Geschichtstheorie, Paderborn.

Hoagwood, Terence Allan (1988): Skepticism and Ideology: Shelley's Political Prose and Its Philosophical Contexts from Bacon to Marx, Iowa City.

Hobsbawm, Eric J. (1971): Primitive Rebels: Studies in Archaic Forms of Social Movements in the 19th and 2oth Centuries, Manchester.

Höfele, Andreas (2005): "Making History Memorable: More, Shakespeare and Richard III”, in: Herbert Grabes (ed.), REAL 21: Literature, Literary History, and Cultural Memory, Tübingen, 187-203.

Hogle, Jerrold E. (1988): Shelley's Process: Radical Transference and the Development of His Major Works, New York, Oxford.

King-Hele, Desmond (1984): Shelley: His Thought and Work, London.

Kleist, Heinrich von (2011): Robert Guiskard, Herzog der Normänner, ed. Carlos Spoerhase, Stuttgart.

Kleist, Heinrich von (2000): Robert Guiskard (Sämtliche Werke: Brandenburger Ausgabe, vol. I/2), ed. Roland Reuß and Peter Staengle, Basel,

Logan, George M. (2005): "Introduction”, Thomas More, The History of King Richard III: A Reading Edition, ed. George M. Logan, Bloomington, xv-lviii.

McNiece, Gerald (1969): Shelley and the Revolutionary Idea. Cambridge, Mass.

Miller, Jacqueline T. (1986): Poetic License: Authority and Authorship in Medieval and Renaissance Contexts, Oxford. 
More, Thomas (1963): The History of King Richard III, ed. Richard S. Sylvester (Yale Edition of the Complete Works of St. Thomas More, vol. II). New Haven.

More, Thomas (1953): The Latin Epigrams of Thomas More, ed. Leicester Bradner \& Charles A. Lynch, Chicago.

Parker, Hershel (1983): “Lost Authority: Non-sense, Skewed Meanings, and Intentionless Meanings", in: Critical Inquiry 9.4, 767-774.

Peck, Walter Edwin (1924): "Unpublished Passages from the Pforzheimer MS. of Shelley's Philosophical View of Reform”, in: PMLA 39:1, 910-918.

Reiman, Donald H., and Neil Freistat (2002): “Shelley's Reputation Before 1960: A Sketch”, in: Shelley's Poetry and Prose, ed. Donald H. Reiman and Neil Freistat, New York, 539-549.

Roper, William (1935): The Life of Sir Thomas More, Knight (1557), ed. Elsie Vaughan Hitchcock, London.

Schmitt, Franziska (2005): Method in the Fragments: Fragmentarische Strategien in der englischen und deutschen Romantik (Studien zur Englischen Romantik, Neue Folge, 2), Trier.

Scrivener, Michael (2013): "Politics, Protest, and Social Reform: Irish Pamphlets, Notes to Queen Mab, Letter to Lord Ellenborough, A Philosophical View of Reform", in: Michael O'Neill \& Anthony Howe with the assistance of Madeleine Callaghan (eds.), The Oxford Handbook of Percy Bysshe Shelley, Oxford, 163-176.

Shelley, Percy Bysshe (1965): A Philosophical View of Reform (The Complete Works of Percy Bysshe Shelley, vol. 7), ed. Roger Ingpen and Walter E. Peck, 10 vols., London, 3-55.

Shelley, Percy Pysshe (1970): Poetical Works, ed. Thomas Hutcheson, rev. G.M. Matthews, Oxford.

Shelley, Percy Bysshe (1964): "Letter to John \& Maria Gisborne, 6 Nov. 1819”, in: The Letters of Percy Bysshe Shelley, 2 vols., ed. Frederick L. Jones, Oxford, II, 148-150.

Shelley, Percy Bysshe (1964): “Letter to Ollier, 15 December 1819”, in: The Letters of Percy Bysshe Shelley, 2 vols., ed. Frederick L. Jones, Oxford, II, 164 .

Shelley, Percy Bysshe (1964): “Letter to Leigh Hunt, 26 May 1820”, in: The Letters of Percy Bysshe Shelley, 2 vols., ed. Frederick L. Jones, Oxford, II, 201. 
Shelley, Percy Bysshe (1964): “Letter to Horace Smith, 29 Jun. 1822”, in: The Letters of Percy Bysshe Shelley, 2 vols., ed. Frederick L. Jones, Oxford, II, $44^{2}$.

von Straßburg, Gottfried (1995): Tristan, ed. with a translation into Modern High German and with commentary by Rüdiger Krohn, 3 vols., Stuttgart.

White, Newman Ivey (1947): Shelley, 2 vols., London. 


\title{
A Miserable Sight
}

The Great Fire of London (1666)

\author{
Christoph Heyl
}

\section{A WOMAN MIGHT PISS IT OUT: A DISASTER IN THE MAKING}

This paper is about events unfolding on a grand scale. It is about the sudden and utter destruction of the historic centre of a large city by the ferocious force of a firestorm, about failure in the sense of an all-too-evident inability to avert this urban mega-disaster. It is about stories that were told about this disaster in order to come to terms with it, to make sense of it and, eventually, to redefine failure as success. The dramatis personae we find in these stories include a king, a pope and none other than God himself.

On September the first 1666, a fire broke out in a bakery situated in the heart of the City of London. This happened in the middle of the night. It began to spread to the neighbouring houses. Smaller fires were fairly commonplace events in early modern London, and this was probably why the danger posed by this particular fire was under-estimated. The Lord Mayor of London was called from his bed. He had one quick look at the fire from a distance and then he went straight back to bed again, saying "Pish! A woman might piss it out". ${ }^{1}$ The events of the following hours were to prove that, in this case, the Lord Mayor's assessment of the situation was wide off the mark. In fact it went down in history as a tragic error of judgement.

Seventeenth-century London was a chaotic rabbit warren of timber-framed houses. A hot and very dry summer had rendered their wooden beams and thatched roofs dry as tinder. To make things worse, there was a steady wind blowing from the east which drove the fire on. The

1 | Porter (1994), 85. 
flames leaped from roof to roof until the fire reached storehouses on the waterfront which contained large quantities of oil and spirits. ${ }^{2}$ These exploded immediately. At that stage, it became absolutely clear that the fire had turned into a major conflagration. As the wind kept blowing, it gathered strength and potential for further destruction by the minute. During this phase of the disaster, there were no organised attempts at all to fight the fire.

There was no such thing as an organised fire brigade in seventeenth-century London. Fire-fighting technology would have been rudimentary anyway. In theory, each parish was supposed to store a supply of equipment to be used by the inhabitants of that parish if the need arose. This included buckets, axes, ladders and fire hooks, i.e. hooks on long poles which could be used to pull down sections of burning buildings. Some parishes provided leather helmets which looked remarkably like the modern Anglo-American type of fireman's helmet that is still in use. There was a small number of manually operated fire squirts. These were implements that looked very much like a large syringe. ${ }^{3}$ They were small enough to be carried and operated by one man, which was also why they were of very limited efficiency. All they could do was to squirt small amounts of water at close range. Larger fire engines - barrels on wheels fitted with a hand-pump and a nozzle that could be directed at the fire had just been developed, but these were still a rarity at the time.

Firefighting technology did in any case not yet rely on ways of extinguishing fires by means of water as a good supply of water would not have been readily available. A trickle of water was carried into the City through wooden pipes. However, the capacity of these conduits would have been in no way sufficient to quench a fire that was getting out of hand. Water could be fetched in buckets from the river, but once again, the amount of water that could be carried into the City in this way would have been limited. The preferred firefighting technique was to pull down burning houses in the hope of thereby extinguishing the flames. This is why the fire hooks

2 | For accounts of the Great Fire, see Bell (1929); Tinniswood (2003); Pepys (1970), 138-140. For early depictions of the Great Fire of London, see Koppenleitner (2011), 45-59.

3 | Examples of these seventeenth-century fire-fighting implements can be found in the collections of the Museum of London which can also be viewed online: archive.museumoflondon.org.uk/Londons-Burning/objects (3 Sept. 2014). 
mentioned above could be of considerable practical importance. Several men operating one of these could easily pull down a timber-framed structure. In the absence of other means to fight a major fire, it made good sense to destroy not only buildings that were already burning but also others that were still intact so as to create a fire-break. On the whole, it was a good idea to destroy a limited number of houses in order to save many others, to create a gap between the fire and the rest of the city so that the fire might be contained.

However, just like fetching water from the river, this would have required the sort of co-ordinated effort which was not forthcoming as the vast majority of people were intent on saving their lives and some of their property. What is more, to create fire-breaks, people would have needed to be willing to sacrifice their own houses before these had even been touched by the fire.

\section{MUCh tROUbled: The King's DILEMmA}

The most important and at the same time the most fascinating eyewitness account of the Great Fire is found in the famous diary of Samuel Pepys. Pepys, a rising bureaucrat in the Navy Office, was an excellent observer. Almost like a modern reporter, he tried to get as close to the action as possible, and he had a good eye for telling details. He also played an important role in the attempt - such as it was - to manage this crisis. Pepys had access to court circles; he was known to the King. When he understood just how serious the situation was, he took a boat to Westminster to spread the news. Eventually the King called for him, and Pepys took the opportunity not only to point out the seriousness of the situation but also to propose a strategy of pre-emptive demolition to stop the fire.

Although the King ordered the destruction of houses, the Lord Mayor of London, Thomas Bloodworth, was not able to organise the concerted effort that would have been required. Samuel Pepys describes the situation on the morning of the first day of the fire thus: ${ }^{4}$

[...] to White-hall, and there up to the King's closet in the chapel, where people came about me and I did give them an account dismayed them all; and word was

4 | Pepys (1970), Vol. VII, 269. 
carried in to the King, so I was called for and did tell the King and the Duke of York what I saw, and that unless his Majesty did command houses to be pulled down, nothing could stop the fire. They seemed much troubled, and the King commanded me to go to my Lord Mayor from him and command him to spare no houses but to pull down before the fire every way. The Duke of York bid me tell him that if he would have more soldiers he shall; and so did my Lord Arlington afterwards, as a great secret.

Pepys went back to the burning City with the King's instructions. However, for the time being, these went unheeded: ${ }^{5}$

[...] At least met my Lord Mayor in Canning Streete, like a man spent, with a handkercher about his neck. To the King's message, he cried like a fainting woman, 'Lord, what can I do? I am spent! People will not obey me. I have been pull[ing] down houses. But the fire overtakes us faster than we can do it. That he needed no more soldiers; and that for himself, he must go and refresh himself, having been up all night. So he left me, and I him, and walked home - seeing people almost distracted and no manner of means used to quench the fire.'

The basic fire-fighting tools provided by the parishes were not used in any co-ordinated manner in the early phase of the fire when the conflagration could perhaps still have been contained. Not enough houses were destroyed in the path of the fire. People lacked the organisation, the resolution and the will to do so. And more importantly, the King lacked the power to make them fight the fire in a much more efficient way.

The role played by the King in the early phase of the Great Fire is of considerable interest. His position (and with it his ability to take decisive action in a state of emergency) differed markedly from that of other monarchs of the period. Both he and his subjects knew that his power was limited. The events of the English Revolution had made it abundantly clear that a King governing without due regard to a consensus with Parliament was in danger of losing his crown and indeed his head. The restoration of the monarchy - and with it the end of the revolutionary period - lay only six years back when the fire broke out. A delicate political balance had been established which needed to be maintained at almost all cost. King

5 | Pepys (1970), Vol. VII, 269-270. 
Charles II knew he had to avoid anything involving a risk of upsetting this balance.

In late seventeenth-century England, the King's power was furthermore limited as he governed under the rule of the law. His subjects were to a large measure protected by law, and the law specifically safeguarded their property. To order the large-scale pre-emptive destruction of houses in the City was to take a considerable risk. The City of London enjoyed a substantial measure of autonomy, being self-governed by an elected Lord Mayor. This autonomy was jealously guarded. For the King to send soldiers into the City was to break a taboo. No matter how useful they might have been under the circumstances, the sight of large numbers of troops marching into the City would have been a political affront. This is why courtiers such as Lord Arlington who were acutely aware of the sensitivity of this issue treated the deployment of troops offered by the King as "a great secret" (see above).

Charles II. took a political risk when, following the advice given by Samuel Pepys, he commanded houses to be pulled down. The King knew that, as the first monarch after the revolutionary period, his status was still precarious. If things went wrong, as they easily could in a multitude of ways, his reign would go down in history as a grand failure - a failure which could well go beyond the loss of his power and even the loss of his life. If Charles II. were to fail as a monarch, this could very well mean the end of the monarchy in his country. Therefore, a great deal depended on whether or not he would be perceived as a good king.

A good king needed to be seen doing something when his capital was going up in flames. However, any sort of royal intervention might end in failure and the loss of political standing associated with it. The King had a great deal to lose either way, doing things or leaving things undone. On the one hand there was the risk of being perceived as a monarch abusing his powers, on the other hand there was the risk of the capital being destroyed by the fire.

The direction in which the fire would spread was clear from the very beginning. Moving from east to west with the prevailing wind, it could conceivably go well beyond the City and into Westminster. The Palace of Westminster, the seat of Parliament and Westminster Cathedral were under threat. Therefore, Charles II decided to listen to Pepys's advice and to take the initiative by commanding the destruction of houses. 
The fact that the King's instructions could not be carried out in the early phase of the Fire demonstrates just how much his power was limited. No royal command could bypass Thomas Bloodworth, the Lord Mayor of the City of London; he needed to pass on and thus endorse the King's orders. However, the Lord Mayor proved to be completely overwhelmed by the disaster. Having underestimated the formidable danger posed by the fire from the very beginning, he did not manage to come up with anything resembling a coherent and practicable strategy during the early phase of the conflagration. For Bloodworth, the protection of both liberty and property must have been a key concern. He found himself in a dilemma: the only way to save houses was to destroy other houses. What is more, he found that most Londoners, intent on joining an ad-hoc exodus from the burning City, simply would not listen to his orders.

Given the political circumstances, it is not surprising that the Lord Mayor immediately declined the offer of more soldiers. To endorse any large-scale deployment of troops in the City would have smacked of giving in to the King, jeopardising the City's formal autonomy. Both the King and Bloodworth knew that, in the aftermath of the fire, they would have to take full responsibility for their actions.

The authorities - in the shape of both the King and the Lord Mayor failed in their attempts to prevent the destruction of most of the City of London. This failure can be connected with the influence and power of new ideas: The King was not all-powerful, the law (and hence the integrity of liberty and property) was sacrosanct, and politicians could count on being held accountable for their actions. All of this made England considerably more modern than most other European countries of the period. However, these modern ideas which limited the power of all authorities prevented these authorities from taking the sort of decisive action that might have saved the City. Both the King and the Lord Mayor hesitated when it came to overriding constitutional and legal constraints. There was therefore a somewhat paradoxical connection between emergent modernity and the poor management of an emergency.

What had begun as a mere fire became a firestorm which raged largely unopposed for two more days. Only on the third day of the disaster did soldiers sent by the King begin their work of large-scale demolition in an attempt to create substantial fire-breaks. It is significant that this did not happen inside the City - which by now had been largely destroyed - but on its very margins and beyond. Here the presence of soldiers was less of an 
embarrassment. As the fire was moving in the direction of Westminster (i.e. outside the area controlled by the Lord Mayor of the City of London), it approached what was widely regarded as the King's sphere of influence. Anything the King ordered to be done there would tend to be regarded as legitimate. What is more, by now the dimensions of the fire had become apparent. This was an urban mega-disaster which legitimised any drastic action taken against it. Thus the crucial issue of acceptance was resolved by the inexorable progress of the fire and the fact that, now it had left the City of London behind (and in ruins), it was threatening the City of Westminster.

Eventually, the fire was brought to a halt. This was not only due to the firefighting that had at last begun in earnest. These efforts were substantially helped by a change in the weather. The wind that had steadily propelled the fire in a westerly direction abated. There was even some rain. Thus, the fire could be contained at long last, and it slowly began to die down.

\section{An act of God: Making sense of the Great Fire}

In the immediate aftermath of the Great Fire, it became apparent how dismally attempts to save the City of London had failed. The fire thus was not only a disaster; it also had the potential to be a huge embarrassment to those who could have done more to fight it. The King in particular must have felt some of this embarrassment as his inability to take decisive action early on demonstrated in very practical terms just how much his power was limited.

On top of this, there was another thing that must have contributed to his unease, and that was an acrimonious debate on the Great Fire that began while the fire was still raging and that continued for months and years to come. ${ }^{6}$ This debate was conducted not only in London's streets (ruined and otherwise) and coffee houses, in clubs and at home, at court and in parliament. The Great Fire was also debated in print, in pamphlets, ballads, poems, sermons, books, woodcuts and engravings.

This debate that agitated Londoners from all walks of life was primarily about the meaning of this disaster. People immediately tried to make

6 | For the debate on the Great Fire, see also: Heyl (2011), 23-44. 
sense of it. After all, it was not just any part of London that had gone up in flames, it was the very heart of the old historic City. This area had always maintained its own identity, emphasising its autonomy from the other half of London, the City of Westminster, and holding on to its own political positions that were frequently opposed to those of the monarch. The destruction of such a place that was pregnant with meaning must have been a meaningful event in itself - at least this appeared to be self-evident to the vast majority of Londoners at the time. One widespread explanation of the Great Fire was to regard it as a punishment meted out by God. However, this explanation immediately gave rise to another crucial question concerning the meaning of this disaster: Why had God chosen to punish Londoners in this way?

Attempts to make sense of this event, to read the divine message it presumably conveyed, were further complicated by the specific historical context of the seventeenth century. The Great Fire of 1666 was not the only traumatic event that occurred during this period. Immediately before the Great Fire, in 1665-6, London had been struck by the Great Plague, the last major outbreak of the bubonic plague. More than 100.000 Londoners had lost their lives. ${ }^{7}$ And just before the Great Plague, there had been the English Civil War, the subsequent revolutionary period and eventually the Restoration of 1660 , all of which, depending on one's political outlook, could be regarded as a horrific disaster. For the Royalists, this disaster culminated in the beheading of King Charles I, while for most of the revolutionary factions, it consisted in the Restoration of the monarchy. Either way, the political events of the seventeenth century would have been experienced as traumatic. This means that the Great Fire was not regarded as an isolated calamity. For most contemporary observers, it appeared to be part of a constellation of disasters. Therefore, they tended to think that the key to understanding the Fire was to make sense of a whole cluster of disastrous events.

The Fire as well as the Great Plague and various aspects of the revolutionary period were predominantly read as punishments meted out by God. Many, probably even most Londoners of the period regarded such acts of God as a response to sins committed in London. London had failed to live up to God's commandments and expectations, so it needed to be punished. However, there was no real consensus when it came to identi-

7 | See Weinreb/Hibber/Keay/Keay (2008), 344. 
fying these sins. This is why the debate on the meaning of the Great Fire was to a considerable extent a debate on possible reasons for God's anger.

One conspicuous feature of this debate was the resurgence of ideas and images that, with the Restoration, had ceased to be part of mainstream political and religious thought. The concept of the apocalypse as something to be expected to happen in one's own lifetime is a case in point. During the English Revolution, apocalyptic thought had featured prominently in republican political propaganda. What many radical revolutionaries wanted was nothing less than the end of the world; they wanted to do their bit to bring on the apocalypse as the ultimate form of revolution. This means that apocalyptic rhetoric acquired clear political connotations, that it was firmly associated with Puritan revolutionary discourse.

When the revolutionary period ended and the monarchy was re-instated in 1660, this concept of the apocalypse appeared to be a thing of the past, embarrassingly obsolete and only fit to be uttered by cranks and extreme political outsiders. However, with the Great Fire, it was suddenly back in fashion again. And so was apocalyptic imagery in visual art. Immediately after the fire, a ballad entitled The Londoners Lamentation was printed. ${ }^{8}$ The usual format for such ballads was one sheet of paper, and they were frequently illustrated with a simple woodcut. This particular ballad was combined with a lurid apocalyptic scene, an apparition in the sky loosely based on the biblical Book of Revelation. ${ }^{9}$ The image found here is much older than the text, it was printed using a woodblock which, based on its style, can be dated to the first half of the seventeenth century. The old image was simply re-cycled, so old apocalyptic imagery was actually back in a physical sense.

From the re-instatement of the Monarchy in 1660 and up to the Great Fire, many Londoners had enjoyed an intensely secular and hedonistic period. This had been come as a considerable relief after the long revolutionary era which had been characterised by Puritanism and its rigorously enforced religious morality. But now, all of a sudden, Puritan preachers were back in business again. The Great Fire brought on a resurgence of the sort of religious rhetoric that had been common in revolutionary England. It is much in evidence in pamphlets and books published in 1667 .

8 | Anon, The Londoners Lamentation, 2 pp. (n.p, n.d.; London 1666).

9 | Reproduced in: Heyl (2011), 31. 


\section{Apparitions! Apparitions! A heated debate}

Some authors really warmed to their subject when they wrote about the Great Fire, revelling in the idea of God's burning anger, of a God whose favourite and most appropriate means of punishing mankind was fire. The title of a book written by Thomas Doolittle is a case in point: Rebukes for sin by God's burning anger, by the burning of London, by the burning of the world, by the burning of the wicked in hell-fire. ${ }^{10}$ The insistent repetitions found in this title neatly encapsulate the distinctive style and the theological approach that are the hallmark of this ad-hoc post-Fire Puritan revival.

Another Puritan preacher, Samuel Rolle, wrote a book entitled Shilhavtiya, שלחבת, or, the Burning of London in the Year 1666. Commemorated and improved in a hundred and ten discourses, Meditations and Contemplations." "שלחבת'ח/Shilhavtiya" means "the Flame of God", and this was indeed what his book was all about. Rolle emphasised time and again that fire was God's proper element, and that God appeared physically in the shape of fire. So while the members of the Royal Society had just begun to understand what fire actually was, that it was not an element but a process to do with the combustion of gases, authors such as Doolittle and Rolle stoutly maintained that fire in general and the Great Fire of London in particular was all about God. ${ }^{12}$

However, when it came to the question of who precisely was to blame for the Great Fire, authors offering a religious reading of this disaster came up with various answers. Doolittle and Rolle were convinced that the disaster was a punishment for the manifold sins of Londoners, and they found it easy to draw up long and detailed catalogues of sins comprising everything Restoration hedonism had to offer.

However, there were also other explanations. The anonymous author of a book entitled Pyrotechnica Loyolana ${ }^{13}$ maintained that the Fire

10 | Doolittle (1667).

11 | Rolle (1667).

12 | "But it is a most acceptable thing to hear their [the fellows of the Royal Society's - C.H.] discourses and see their experiments; which was this day on the nature of fire, and how it goes out in a place where the ayre is not free, and sooner out where the ayre is exhausted; which they showed by an engine on purpose." Pepys (1970), 36.

13 | (Anon.), Pyrotechnica Loyolana, 1667. 
had been deliberately started by Catholic arsonists. He was sure that the culprits were Jesuits acting on the instructions of the pope. Pyrotechnica Loyolana came with a remarkable frontispiece in which the pope appears, sitting on his throne in Rome and fanning the Great Fire of London with a huge pair of bellows. He is assisted by a group of Jesuits seen standing around an outsize globe, obviously intent on planning a global campaign of arson.

According to this interpretation, the Great Fire was not a punishment meted out by God. It was an evil Catholic attack on the Protestant religion, that is, on the true believers. For the author of Pyrotechnica Loyolana, the Fire had not, as Doolittle and Rolle believed, been sent down from heaven - on the contrary, it had come straight out of hell. This point was driven home in somewhat clumsy rhyme: ${ }^{14}$

And we now do know that this flame

From Hell and Purgatory came

This reading of the Great Fire as the result of an attack carried out by foreign powers was plausible to many Londoners. Samuel Pepys recorded in his diary that while the fire was still raging, there were widespread fears of an imminent invasion and that at that time foreigners were very much under suspicion. ${ }^{15}$ Conspiracy theories gained even more credence when a Frenchman by the name of Robert Hubert surrendered himself to the authorities, confessing to having started the Great Fire by means of an incendiary device, a kind of firebomb. ${ }^{16}$ Although the man was clearly deranged (he had probably not even been anywhere near the City of London on the night the fire began), a scapegoat of some sort was badly needed, so he was duly executed. ${ }^{17}$

The story of arson at the hands of a Catholic survived for a very long time. This conspiracy theory allowed for a range of different interpretations. Thomas Vincent, a Puritan divine, published a book about the Great

14 | (Anon.), Pyrotechnica Loyolana, 132.

15 | Pepys (1970), 277.

16 | Hubert is depicted in the frontispiece of (Anon.), Pyrotechnica Loyolana.

17 | See Porter (2004). 
Fire entitled God's Terrible Voice in the City (1667). ${ }^{18}$ Vincent was certainly among those who believed in a Catholic conspiracy. However, for him, the Catholic arsonists were simply a means used by God to punish Londoners for their sinfulness. Unlike the unknown artist who created the drastic frontispiece for Pyrotechnica Loyolana featuring the pope with his bellows fanning the flames of the Great Fire, Vincent casts God in this role: "[...] and God with his great Bellows blowes upon it, which makes it spread quickly [...]". ${ }^{19}$

As a Puritan preacher, Vincent was a professional when it came to writing fire and brimstone sermons. When he wrote about the Great Fire, he really pulled out all the stops. For him, the fire was not only the voice of God, it was also a visible manifestation of God. In Vincent's text, God, rendering himself both audible and visible through fire, takes centre stage in an apocalyptic scenario: ${ }^{20}$

Awake! then 0 London awake! open thine eyes, draw thy curtains, come forth of thy bed; look out of thy windows; Apparitions! Apparitions! strange sights to be seen; Behold! Heaven is opened, and God is come down upon earth, cloathed with garments of lightning: God is come down in his Majesty, and looks upon London with a terrible countenance: Behold the amazing terrour of God in the late strange and prodigious Judgments. What! doest thou not seen him? Surely thou art fast asleep still, thine eyes are closed, the vail is before them.

Awake! London Awake! open thine ears, Harke! Oh the Trumpet that hath been sounding from Heaven over the City exceeding loud! Oh the Thundrings of the terrible voice of the Angry God! The voice of the Lord hath been powerful and very dreadful: What! canst thou sleep under such a noise?

The texts written in the aftermath of the Great Fire preserve the outlines of a debate over the significance of this disaster, and they vividly convey a sense of just how acrimonious the debate about the meaning of this event must have been. Tempers got hot because the contributions to this debate were based on conflicting religious and political agendas. Puritans hated the current Royalist establishment they regarded as godless, and Royalists

18 | Anon. (“T. V." = Thomas Vincent), God's Terrible Voice in the City, [London] 1667.

19 | Vincent (1667), 56.

20 | Vincent (1667), 194. 
hated the Puritans because they regarded them as revolutionaries. The debate on how to read the great Fire brought a powerful resurgence of the sort of partisan rhetoric - both Puritan and Royalist - associated with the Civil War.

One reader of Vicent's Puritan tract on the Great Fire was so enraged by his ideas that he carried on the debate about the meaning of the disaster by annotating his own copy of the book. His manuscript notes amount to a full frontal attack on the author. He was convinced that firebrand preachers such as Vincent had been responsible for the English revolution in general and the execution of King Charles I. in particular, and that God now punished these Puritans with the Great Fire. Here is part of what this anonymous reader wrote in the margins of Vincent's book: ${ }^{21}$

Such Minesters as this trumpeted that horrid Rebellion in 1641, which followed ye overthrow of both Church \& State [...] This Rebellion occasioned that Barbarous \& Audatious Murder of this $\rightarrow$ GOD's King a pious \& goode King, which the Gospell Ministers to work their ends falsly bespattered with abominable false lies, which I am thorryly persuaded was the Greatest Cause of those Judgments on London.

Here we have a Royalist reader fuming over a Puritan preacher coming out of the woodwork and trying to make a triumphant comeback. His acerbic textual intervention shows how the debate over the meaning of the Great Fire immediately touched a nerve. People across the religious and political spectrum put forward conflicting readings of the event, and they did so with considerable verve. Some saw an evil Catholic conspiracy against Protestantism behind the Fire. For others, it was a Catholic conspiracy ordained by God as a just punishment. Puritans (who were not happy with the restoration of the monarchy) said that God was punishing non-Puritan Royalists. Non-Puritans accepting the new order brought by the Restoration said that God was punishing the Puritans who had started the ungodly political upheavals of the English revolution.

21 | Vincent (1667), anonymous manuscript notes found on the last (unpaginated) page of the dedication. The annotated copy of Vincent's book is found in the library of the University of Illinois (Urbana-Champaign Campus); it is reproduced in Early English Books Online. The marginal annotation discussed here is also reproduced in: Heyl (2011), 37. 


\section{Purged With the fire: Royal PROPAgANda}

This debate was a threat to the stability of the political system. Six years after the Restoration, the King's hold on power was still far from secure. Many ideas brought forward in various attempts to read the fire, to identify its cause and to make sense of it must have appeared downright dangerous to Charles II. When people pointed their finger at Catholics in general and at the pope in particular, the implication was that both the court and the King himself were to be regarded with suspicion. After all, Charles II's queen was a Catholic, his brother, the Duke of York, who was the heir apparent to the throne, was a Catholic as well, and the King himself was known to sympathise with Catholicism.

What the King needed in this situation was a great deal of efficient Royalist propaganda. He needed a different narrative about the Great Fire, a narrative in which he could appear in the role of a good and successful monarch. This version of the story needed to be put about in ways which, ideally, could make it the dominant narrative about this disaster.

This was not an easy thing to do as the King had not been in a position to take decisive action in the early phase of the Fire. This conspicuous moment of weakness needed to be turned into something that could be perceived as a moment of strength. An embarrassment needed to be re-packaged as a triumph to bolster his authority and thus to put an end to a dangerous discussion that gave Puritan anti-monarchists a chance to air their views.

This is why, in the immediate aftermath of the disaster, we find the first attempts to interpret the Great Fire not as a punishment but as a good thing. Just twelve days after the fire had come to an end, the King issued a remarkable royal proclamation. In this, he (probably with some help from able advisers) introduced the idea that the Fire was really a golden opportunity for London, that now one had a chance to build a new and much more beautiful metropolis, "to make it rather appear to the world as purged with the Fire [...] to a wonderful beauty and comeliness". ${ }^{22}$ The metaphor was well-chosen: The fire was re-interpreted as a purge, as a bitter pill with unpleasant effects which, however, is part of a necessary and efficient therapy that will make the patient better. The notion of the Fire

22 | Stuart, His Majestie's Declaration to his City of London, 16 September 1666, 2. 
being a punishment sent by God briefly appears in the proclamation, but in such a way that it pales into insignificance compared to the idea of God pursuing an altogether different agenda.

Thus the royal proclamation floated the idea that God had merely used the fire to clear some space for a new, much more beautiful and magnificent London. At least as far as the rebuilding of London was concerned, such claims were not entirely without substance. The proclamation announced rules and regulations for the re-building of the City which, among other things, introduced an entirely new aesthetic of terraces with uniform facades. Making a virtue out of a dire necessity, considerable thought was given to matters of proportion and symmetry. The proclamation made sure that the re-building of the City of London would indeed amount to an aesthetic transformation.

This idea of the fire being, on balance, a good thing was immediately taken up by others. A clear echo of it can be found in a broadsheet poem entitled London Undone; or, A Reflection upon the Late Disasterous Fire. The close intertextual link with the royal proclamation suggests a date of publication in September 1666 , i.e. still in the immediate aftermath of the fire. Here are the concluding lines of this poem: ${ }^{23}$

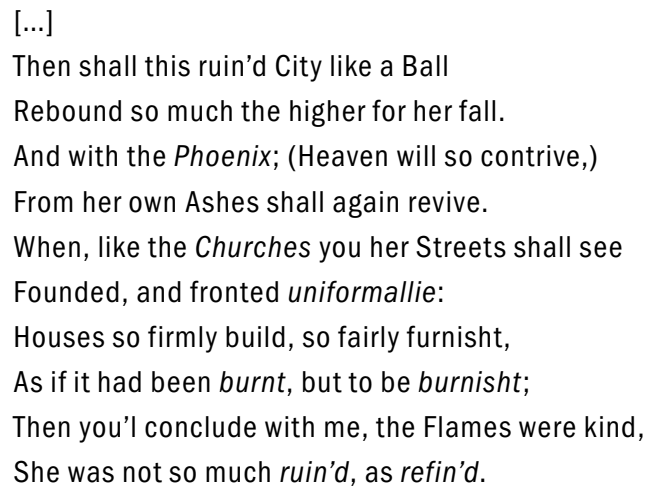

It may very well be that this broadsheet was part of a concerted propaganda effort rather than evidence for spontaneous agreement with the idea that the fire had not been such a bad thing after all. It is likely that the

23 | (Anon.), London Undone; or, A Reflection upon the Late Disasterous Fire (London, 1666). 
King and his advisers used such ephemera to spread what in the immediate aftermath of the fire must have been a fairly counter-intuitive idea.

\section{Annus Mirabilis: From faIlURe to triUmph}

The most vigorous and striking re-interpretation of the Great Fire as a positive event can be found in a long narrative poem by John Dryden which was entitled Annus Mirabilis, The Year of Wonders, 1666. ${ }^{24}$ In this poem he describes some naval victories over the Dutch (which had also happened in that year) and the Great Fire of London. Both events are presented as miraculous in the sense of wonderful and worth celebrating. Dryden's poem is informed by a Royalist perspective, it is both a polished piece of literature and a polished piece of propaganda. This becomes apparent in his choice of imagery. Dryden uses an epic simile to compare the Great Fire to an upstart usurper (and, by implication, to a low-born revolutionary) whose first aim is to destroy the seats of secular and religious powers, and with that state and church: ${ }^{25}$

As when some dire Usurper Heav'n provides,

To scourge his Country with a lawless sway:

His birth, perhaps, some petty Village hides,

And sets his Cradle out of Fortune's way:

$[\ldots]$

Such was the rise of this prodigious fire,

Which in mean building first obscurely bred,

From thence did soon to open streets aspire,

And straight to Palaces and Temples spread.

This revolutionary usurper is a monstrosity, and therefore he appears as a monster: “[....] th' infant monster, with devouring strong/Walk'd boldly upright with exalted head." ${ }^{26}$ The place where the fire began (which was a bakery) is metaphorically turned into a prison, hence the monstrous revo-

24 | Dryden (1667).

25 | Dryden (1667), 54-55 (stanzas 213 and 215).

26 | Dryden (1667), 55 (stanza 218). 
lutionary usurper is also a jailbird on the run. His mere existence is an insult: "So scapes th' insulting fire his narrow Jail [...]". ${ }^{27}$ All of this is a far cry from the idea of the fire as a scourge wielded by God.

Dryden then proceeds to construct his own narrative of the Great Fire using the conventions of epic poetry. He incorporates actual events into this narrative; however, he sometimes does so in an extremely fanciful way. Just like the vast majority of other texts written on the conflagration in late 1666 and in 1667 , it contains a reference to the steady wind that propelled it. However, in doing so, Dryden comes up with an image that would certainly have amused the court and its hangers-on, i.e. people who were known for their hedonism and especially their very active sex lives. The winds blow, so Dryden poetically describes them as "crafty courtezans", as high-class prostitutes who only do their job which, in this case, happens to be a long and lingering a blow job: ${ }^{28}$

The winds, like crafty Courtezans, with-held

His flames from burning, but to blow them more

This frivolity was not just gratuitous. It served a purpose. In Dryden's poetic account, the fire is being secularised, it is controlled not by God but by winds acting like prostitutes. This was a calculated provocation guaranteed to enrage any Puritan reader who might have come across this text while it might well have put a smile on the face of hedonists such as Samuel Pepys. Later on, the fire's consuming heat is once again sexualised (it spreads its "longing flames", a phrase that would not appear out of place in erotic poetry of the period). ${ }^{29}$

Then, Dryden describes the Fire in military terms. It is like a hostile army trying to destroy the capital. Things come to a head when this army makes for the palace (i.e. when most of the City has been destroyed and the fire begins to move on in the direction of Westminster): "[...] the main body of the marching foe/Against th' Imperial Palace is design'd." ${ }^{30}$

The conflagration is turned into a fierce epic battle. Fighting and fire-fighting merge into one. In this context, the King, Charles II, appears

27 | Dryden (1667), 56 (stanza 220).

28 | Dryden (1667), 56 (stanza 221).

29 | Dryden (1667), 59 (stanza 233).

30 | Dryden (1667), 60 (stanza 237). 
as the heroic commander-in-chief who at last makes his grand entry: "Now the day appears, and with the day the King [...]." ${ }^{31}$ He is cast as a saviour both in secular and in religious terms. When things become desperate, the King, like a modern Moses, addresses God and begins to negotiate. He reminds him that the last disaster, the Great Plague, had perhaps been not quite fair because it affected both the just and the unjust. Then he offers himself as a sacrifice: "On me alone thy just displeasure lay,/But take thy judgments from this mourning land." ${ }^{32} \mathrm{He}$ is thereby cast in a messianic role. When the King reminds God that the impending destruction of London's naval magazines would mean the end of England as a global power, God sees sense at last and immediately sends an angel to drive away the fire: ${ }^{33}$

Th' Eternal heard, and from the Heav'nly Quire

Chose out the Cherub with the flaming sword

And bad him swiftly drive th'approaching fire

From where our Naval Magazines were stor'd.

The Cherub and the flaming sword were of course familiar ideas associated with the wrath of God. ${ }^{34}$ However, this avenging angel is sent to do something about the fire rather than to do something to the inhabitants of London, which indicates that God does have London's best interests at heart after all. Soon after this, God proceeds to extinguish the fire, using a giant extinguisher in the shape of a huge hollow pyramid (modelled on the implement used to extinguish candles at the time). Just to make sure, this pyramid is "in firmamental waters dipt above". ${ }^{35}$ London has been saved by the King's intervention, the disaster is turned into a miraculous triumph: ${ }^{36}$

31 | Dryden (1667), 60 (stanza 238).

32 | Dryden (1667), 67 (stanza 265).

33 | Dryden (1667), 69 (stanza 271).

34 | Especially after the fall of man, see Genesis 4, 24: "So he drove out the man; and he placed at the east of the garden of Eden Cherubims [sic!], and a flaming sword which turned every way [...]." (King James Bible.)

35 | Dryden (1667), 72 (stanza 281).

36 | Dryden (1667), 72 (stanza 283). 
Our King this more then [sic!] natural change beholds;

With sober joy his heart and eyes abound:

To the All-good his lifted hands he folds,

And thanks him low on his redeemed ground.

The ground is redeemed, the king is the redeemer - an epithet usually reserved for Christ. Charles II is thus once again characterised as a messianic figure. What is more, he is God's anointed, God's representative and deputy on earth: ${ }^{37}$

The Father of the people open'd wide

His stores, and all the poor with plenty fed:

Thus God's Anointed God's own place suppli'd,

And fill'd the empty with his daily bread.

"God's anointed" carries a double meaning. It alludes to the King's super-natural status once he has been anointed as part of the coronation ritual. I also alludes to the etymology of the word "messiah": ha'Maschiach (המשיח) means "the anointed one". The notion of the King being God's anointed was an established topos in English Royalist rhetoric. To describe him as God's deputy on earth ("God's own place suppli'd") alludes to his role as head of the Anglican Church.

Dryden does his best to glorify both Charles II and the new London that was yet to be (re-)built: ${ }^{38}$

Me-thinks already, from this Chymick flame, I see a City of more precious mold

Rich as the Town which gives the ${ }^{c}$ Indies name

With Silver pav'd, and all divine with Gold.

(c) Mexico

More great then humane, now, and more ${ }^{\mathrm{d}}$ August, New deifi'd she from her fires does rise:

37 | Dryden (1667), 73 (stanza 286).

38 | Dryden (1667), 74-75 (stanzas 294 and 296). 
Her widening streets on new foundations trust, And, opening, into larger parts she flies.

(d) Augusta, the old name of London.

He is talking about a triple chemical transformation caused by the Great Fire. First of all, the city's architectural substance is transformed: now we have widening streets, new foundations and a general expansion. On second level, the fire transforms everything into gold and silver. In other words: the new London will be an incredibly wealthy city. And at the same time, he is talking about a third-level transformation in religious terms: London becomes "more great than humane", it becomes "deified". All of this is caused by the fire, by its "chymick flame", so the fire eventually emerges not as a punishment but as a blessing.

Annus Mirabilis is a remarkable example of political chutzpah. Dryden managed to present an urban mega-disaster as a cathartic event. The poem tried very hard to cancel out the memory of the King's weakness, his conspicuous lack of power when it came to fighting the fire in its early stages. A moment of failure was turned into an epic success. Annus Mirabilis was an attempt to establish a dominant reading of the Great Fire which would hopefully triumph over a re-emerging Puritan agitation that was religious and political in equal measure. Immediately after the Fire, Puritan preachers began to occupy the religious and moral high ground. With Dryden's poem, the Royalist side fought back, trying to turn the fire into a propaganda victory for the King. Like his Puritan opponents, Dryden dared to revive the rhetoric of the Civil War - in his case, the Royalist rhetoric. In a manner of speaking, he thus fought fire with fire.

The conflicting interpretations of the Great Fire and its meaning discussed here demonstrate that a disaster could be what you made of it. ${ }^{39}$ Whether something was a crushing defeat or an epic success was very much a matter of interpretation. More precisely, it was a matter of whether the majority of people could be persuaded to follow one particular interpretation if the meaning of an event was contested. These were not merely academic questions. Since the 1640 s, since the Civil War, there had been a rapidly developing public sphere in England. It had become normal to

39 | Incidentally, much the same can be said about the second great topic of Annus Mirabilis, the naval victories over the Dutch. After a major engagement at sea, both sides claimed victory. See Pepys (1970), 150-155. 
conduct political and religious debates through printed texts and images. It was widely understood that there was a crucial link between the power to explain things and political power. It was therefore important to come up with explanations. They might well be utterly fanciful, but they needed to be palatable.

The interpretation of the Great Fire put forward by Royalist propaganda proved to be dominant. It was so successful because it was communicated on various audience-specific levels of sophistication: broadsheet poems, ballads and woodcuts for the common people, and an epic poem in the shape of Annus Mirabilis for the educated. The idea of the Great Fire as a golden opportunity for London, as the event that gave birth to a new, modern and therefore much better London became ubiquitous in the historiography of the $18^{\text {th }}, 19^{\text {th }}$ and $20^{\text {th }}$ centuries.

Thus the story of a disaster became a success story. As such, it remains to be read to this day, physically inscribed in a monument simply known as "The Monument". The Monument - i.e. the Monument for the Great Fire - is a prominent London landmark, a giant structure completed in the 1670 s which is still the world's highest free-standing column. It is still very much an element of the collective mental map of the City because there is an underground station called "Monument". The Great Fire is thus an event that remains permanently inscribed in the map of modern London's public transport system. What is more, the Monument perpetuates the reading of the event put forward by the Royalist propagandists on behalf of Charles II.

The massive base of the Monument's giant column is decorated with a complex allegorical representation of the aftermath of the Great Fire. On the left hand of a huge bas-relief panel, one can see London, represented by a downcast mourning female figure. To the right, there is King Charles II in the pose of a Roman emperor coming to her assistance. Behind the woman, there is a male figure offering to support her. This figure is bald, apart from a very prominent forelock. To classically educated viewers of the period, he would have been instantly recognisable as a representation of opportunity, of the right moment, of what the ancient Greeks called the Kairos.

The idea was that the Kairos suddenly appeared in front of you. You had to seize him by the forelock immediately or else he would be gone. (This is the origin of the phrase "to grab time by the forelock".) This Royalist propaganda image was put up while London was still being re-built 
and while the debate about the Great Fire was still going on. Here the idea of the fire as a golden opportunity was carved in stone - for all to see and for all time.

\section{WORKS CITED}

Anon. (“T. V." = Thomas Vincent) (1667): God's Terrible Voice in the City, Wherein you have: I. The sound of the Voice, in the Narration of the two late Dreadfull Judgments of Plague and Fire, inflicted by the Lord upon the City of London [...] II. The Interpretation of the Voice, n.p. [London].

Anon. manuscript notes in a copy of: Anon. (“T. V." = Thomas Vincent): God's Terrible Voice in the City, n.p., [London] 1667, last page of unpaginated preface. Annotated copy held in the University of the University of Illinois, Champaign-Urbana.

Anon (n.d., 1666).: The Londoners Lamentation, 2 pp., n.p [London].

Anon. (1666): London Undone; or, A Reflection upon the Late Disasterous Fire, London.

Anon. (1667): Pyrotechnica Loyolana, Ignatian Fire-Works, or, the Fiery Jesuits Temper and Behaviour (London).

Bell, George Walter (1929): The Great Fire of London in 1666 (London).

Bible: The Holy Bible [...] appointed to be read in Churches. Authorized King James Version. (King James Bible).

Doolittle, Thomas (1667): REBUKES FOR SIN by GOD'S BURNING ANGER; BY THE BURNING OF LONDON, BY THE BURNING OF THE WORLD, BY THE BURNING OF THE WICKED IN HELL-FIRE [...] Occasioned by the General Distractions of the Present Times, London.

Dryden, John (1667): Annus Mirabilis, The Year of Wonders, 1666, an Historical Poem containing the Progress and various Successes of our Naval War with Holland [...] and describing the Fire of London, London.

Heyl, Christoph (2011): "God's Terrible Voice in the City: Frühe Deutungen des Great Fire of London, 1666-1667”, in: Koppenleitner/Rößler/Thimann (edd.): Urbs incensa, 23-44.

Koppenleitner, Vera Fionie/Rößler, Hole/Thimann, Michael (edd.) (2011): Urbs incensa. Ästhetische Transformationen der brennenden Stadt in der Frühen Neuzeit, Berlin and Munich.

Koppenleitner, Vera Fionie (2011): “Etiam periere Ruinae. Katastrophenereignis und Bildtradition in der Darstellung des Großen Brands von 
London 1666", in: Koppenleitner/Rößler/Thimann (edd.): Urbs incensa, 45-59.

Pepys, Samuel (edd.: Latham, Robert/Matthews, William) (1970): The Diary of Samuel Pepys. A New and Complete Transcription, 11 Vols., London. Porter, Roy (1994): London. A Social History, London.

Porter, Stephen (2004): “Farrinor, Thomas/Hubert, Robert”, in: Oxford Dictionary of National Biography, online edition, Oxford University Press, September, www.oxforddnb.com.proxy.ub.uni-frankfurt.de/view/article /76314 (4. November 2014).

Rolle, Samuel (1667): שלחבת'ח, or, the Burning of London in the Year 1666, commemorated and improved in a CX Discourses, Meditations and Contemplations, London.

Seventeenth-century fire-fighting implements in the collections of the Museum of London: archive.museumoflondon.org.uk/Londons-Burning /objects (3 Sept. 2014).

Stuart, Charles (King Charles II): His Majestie's Declaration to his City of London, upon Occasion of the late Calamity by the Lamentable Fire, London, 16 September 1666.

Tinniswood, Adrian (2003): By Permission of Heaven. The Story of the Great Fire of London, London.

Weinreb, Ben/Hibbert, Christopher/Keay, Julia/Keay, John (edd.) (2008): The London Encyclopaedia. Third Edition, London. 



\title{
Warum Religionsgespräche scheitern
}

\author{
Anmerkungen zum innerchristlichen Diskurs
}

des 16. Jahrhunderts

\section{Marcel Nieden}

Der gewählte Obertitel bedarf einer Vorbemerkung. Er scheint die dialogischen Bemühungen zwischen den Religionen generell unter das Verdikt der Vergeblichkeit zu stellen, gleichsam als seien Religionsgespräche per se und von vornherein zum Scheitern verurteilt. Obwohl eine solche Annahme in kultur- und religionspessimistischen Milieus, denen Fragen der Religion letztlich Fragen des individuellen Geschmacks darstellen, heute wohl nicht ohne Beifall bliebe - De religionibus non est disputandum! -, setzen die folgenden Überlegungen durchaus nicht die Überzeugung voraus, dass über den Wahrheitsanspruch und die Weltdeutung von Religionen nicht gestritten und in dieser Hinsicht keine Verständigung erzielt werden könne. Die scheinbar nur allzu weite Formulierung des Obertitels ist vielmehr historisch veranlasst und mit dem Untertitel unbedingt zusammenzusehen. Sie bezieht sich, wie wir sogleich sehen werden, auf einen relativ klar umrissenen geschichtlichen Phänomenbereich: die innerchristlichen Religionsgespräche des 16 . Jahrhunderts. Dass diese Gespräche samt und sonders scheiterten, mag zwar auf den ersten Blick als eine gewagte Behauptung erscheinen. Es haben sich ja im 16. Jahrhundert durchaus Stimmen gefunden, die im Rahmen des einen oder anderen Religionsgesprächs wenigstens Teilerfolge konstatierten. ${ }^{1}$

1 | Siehe etwa das Statement Johannes Ecks (1486-1543) im Zusammenhang der Regensburger Verhandlungen 1541: "Cum Vormatiae articulus de peccato originali bene fuerit concordatus et utrinque receptus, colloquentes nos ad eandem concordiam remisimus parvi facientes involutam et discordantem libri explanationem." ["Nachdem in Worms der Artikel von der Erbsünde in überzeugender 
Allein, die Mehrheit der Zeitgenossen urteilte anders. Und auch eine sich um konfessionelle Neutralität bemühende historische Forschung kommt heute schwerlich um die Feststellung herum, dass den von der Konstellation her durchaus unterschiedlichen innerchristlichen Religionsgesprächen - nimmt man einmal an, dass sie sich einem wie auch immer näher zu bestimmenden Konkordienwillen verdankten - insgesamt wenig bis gar kein Erfolg beschieden war.

Es stellt sich die Frage: warum? Die durchgängige Erfolglosigkeit der Gespräche legt die Vermutung nahe, dass sich unabhängig von den jeweiligen historischen Konstellationen grundsätzliche, gleichsam strukturelle Gründe bestimmen lassen, die für das Scheitern der Gespräche verantwortlich zu machen sind. Diese Vermutung möchte ich im Folgenden überprüfen, indem ich versuche, Bedingungsfaktoren zu identifizieren, die schon für sich allein, erst recht aber im Verbund den Erfolg des jeweiligen Gesprächs zu verhindern vermochten. Der umfassenden Perspektive nach kann es sich nur um eine vorläufige Zusammenstellung handeln, die der weiteren Überprüfung durch komparatistische Studien bedarf. ${ }^{2}$

Dazu ist zunächst der historische Gegenstandsbereich der Religionsgespräche zu umreißen; anschließend sind die Erwartungshaltungen an diese Gespräche zu eruieren, soweit die Quellen diese zu erkennen geben. Erst vor diesem Hintergrund lässt sich dann genauer nach den historischen Ursachen des Scheiterns fragen. Abschließend sollen die Beobachtungen gebündelt und auf die Frage hin bedacht werden, worin die historische Bedeutung dieser eigentümlichen Geschichte des Misslingens zu sehen ist.

Weise verglichen und von beiden Seiten aufgenommen worden war, schickten wir Gesprächspartner uns (in Regensburg) zu derselben Eintracht an, gaben dann freilich eine verwickelte und strittige Erklärung des kleinen Buches."] (Dittrich (1892), 10) Vgl. Pfnür (1980), 71, Anm. 95.

2 | Verglichen mit den zahlreichen, teilweise recht gründlichen Untersuchungen einzelner Religionsgespräche, sind komparatistische Studien zu dem Thema immer noch dünn gesät. Abgesehen von den Überblicksartikeln in den Lexika und Handbüchern sind vor allem folgende Studien einschlägig: Hering (1836/38); Beumer (1964), 321-332; Fraenkel (1965); Moeller (1970), 275-324 und Moeller (1974), 213-364; Müller (1980); Hollerbach (1982); Fuchs (1995); Decot (2007), 110-139; Scheib (2009/10). 


\section{KontuREn des GegenstandS}

Dialogische Begegnungen von Christen unterschiedlicher Glaubensüberzeugungen hat es im Zusammenhang der Reformation vielfach gegeben. Schon in den Anfängen der reformatorischen Bewegung markieren solche Begegnungen verlaufsgeschichtliche Zäsuren. Zu erinnern wäre hier etwa an die Leipziger Disputation von 1519 zwischen Martin Luther, Andreas Karlstadt auf der einen und Johannes Eck auf der anderen Seite, an die beiden Züricher Disputationen von 1523 unter maßgeblicher Beteiligung Huldrych Zwinglis oder an das Marburger Religionsgespräch von 1529 zwischen den Wittenberger sowie den Schweizer und oberdeutschen Reformatoren. Ein oberflächlicher Blick auf diese Begegnungen dürfte genügen, um sich die Disparität der Veranstaltungen zu vergegenwärtigen, die als »Religionsgespräche« bezeichnet werden können.

Dieser Eindruck wird durch terminologische Beobachtungen noch verstärkt. Der Ausdruck »Religionsgespräch « begegnet in den Quellen des 16. Jahrhunderts nur selten und offenbar erst spät. ${ }^{3}$ Die Bezeichnungen für den hier anvisierten historischen Gegenstand sind meist andere: colloquium, disputatio, unterredung, tractat oder einfach nur gesprech. ${ }^{4}$ Diese Begriffe sind nicht nur in sich semantisch polyvalent, sie werden in den Quellen zu allem Überfluss häufig noch pleonasmusverdächtig gepaart, sodass sich aus der zeitgenössischen Terminologie schwerlich

3 | Das gilt zumindest für die Aufnahme des Begriffs in den Titeln von Druckwerken. Einer der frühesten Belege dürfte sein: Christoph Erhard, Newer Euangelischer Catechismus. Das ist: Ein sehr nützliches/lustigs vnd kurtzweiliges Religionsgespräch/eines Catholischen Christen/vnd Evangelischen Lutheraners/in Form und Weise eines Catechismi. Sampt angehengtem Lutherischen Irrgarten [...], München 1589. Getrennt begegnen die beiden Begriffsbestandteile gelegentlich schon zuvor; siehe etwa [Martin Bucer,] Etliche gesprech ausz Göttlichem vnnd geschribnen Rechten vom Nürnbergischen fridestand/der streitigen Religion halb/Anno etc. xxxij. Franckfortischen anstand/jüngst im Aprillen dises xxxix. jars auffgericht. Künftiger handlung gen Nürnberg angesehen/den span der Religion hinzulegen [...], Augsburg 1539; Christian Francke, Ein Gesprech Von Jesuitern Allen frommen Christen/die Jesuiter vnd ihre Religion recht zu erkennen/Vast nützlich zulesen [...], Basel 1581.

4 | Vgl. Hollerbach (1982), 6-7. 
ein distinkter Begriff des Religionsgesprächs gewinnen lässt. ${ }^{5}$ Die Definition des Begriffs kann daher nur nach den Maßstäben gegenwärtiger historischer Betrachtung erfolgen. ${ }^{6}$

Ohne die Diskussion der Forschung hier im Einzelnen aufrollen zu können, möchte ich im Folgenden ein Konzept des Religionsgesprächs von mittlerem Umfang zugrunde legen, das nicht einfach jede dialogische Begegnung zwischen divergenten christlichen Gruppen umfasst, noch auch sich nur auf die vom Kaiser initiierten »Reichsreligionsgespräche« erstreckt. Im Anschluss an die Definitionen von Marion Hollerbach und Irene Dingel verstehe ich das »Religionsgespräch« als ein öffentliches »Forum der theologisch-politischen Auseinandersetzung«, das auf eine obrigkeitliche Initiative hin Repräsentanten verschiedener christlicher Bekenntnis- oder Überzeugungsgemeinschaften zum Zweck der Überwindung konfessioneller Gegensätze vereint. ${ }^{7}$ Das so definierte »Religionsgespräch« diente letztlich der Depluralisierung des christlichen Glaubens, indem es die vielfältig aufbrechenden Glaubensanschauungen homogenisieren sollte.

Was die angesprochene obrigkeitliche Initiative betrifft, so werde ich mich auf diejenigen Religionsgespräche konzentrieren, die durch Initiativen des Kaisers oder der Fürsten zustande gekommen sind. Diese Entscheidung liegt darin begründet, dass die von den städtischen Obrigkeiten, Rat oder Magistrat, initiierten Gespräche, die in den $20 e r$ und zoer

5 | Vgl. die Beispiele bei Moeller (1974), 353-354.

6 | Der Ausdruck "Religionsgespräch" ist allerdings auch in der gegenwärtigen Diskussion kein klar umrissener Begriff; vgl. die sondierenden Bemerkungen bei Pfnür (1988), 223-226.

7 | Hollerbach (1982), 1: "Religionsgespräche als Forum der theologisch-politischen Auseinandersetzung zwischen den sich bildenden Konfessionen [...]." Dingel (1997), 655, 1-7: "Soll dies jedoch geschehen, muß das Religionsgespräch verstanden werden als ein öffentliches 'Forum der theologisch-politischen Auseinandersetzung، (Hollerbach 1), das durch obrigkeitliche Initiative eingesetzt wird, um in Konfrontation von Repräsentanten verschiedener Glaubens- oder Bekenntnishaltungen der konfessionellen Annäherung bzw. Vereinheitlichung zu dienen, sei es durch Wiedervereinigung der gegnerischen Lager mit Hilfe einer bekenntnismäßigen Kompromißlösung, durch Ausgrenzung oder durch Rückgewinnung des Gegners auch in gegenreformatorischer Absicht." Zur Diskussion vgl. Scheib (2009/10), Bd. 2, 641-644. 
Jahren des 16. Jahrhunderts begegnen, nur in eingeschränktem Sinn als »Gespräche « zu verstehen sind. Sie orientierten sich am Muster der akademischen Disputationen, folgten also weithin einer hochritualisierten Diskussionstechnik auf der Grundlage der aristotelischen Topik. ${ }^{8}$ Dieses Verfahren ließ jedoch keine Kompromissformulierungen zu und bot insofern einem dialogischen Vermittlungsprozess nur ein denkbar dürftiges Instrumentarium. Die vom Kaiser oder von den Fürsten initiierten Gespräche lösten sich dagegen von dem Modell der kommunalen Disputationen und nahmen eher den Charakter eines »Gesprächs« (colloquium) an im Sinn eines freieren, das strenge Korsett der Syllogistik überschreitenden Austauschs von Meinungen. ${ }^{9}$

Prägten die überwiegend der nachträglichen Legitimierung reformatorischer Maßnahmen dienenden städtischen Disputationen ${ }^{10}$ den Zeitraum der zwanziger Jahre, so begann ab den dreißiger Jahren die Ära der Religionsgespräche. ${ }^{11}$ Die von Ferdinand I. (1503-1564) in Stellvertretung Kaiser Karls V. angeregten Ausgleichsverhandlungen auf dem Augsburger Reichstag von 1530 können bereits als inoffizielles Religionsgespräch

8 | Vgl. Moeller (1970), 301-305, der von der Konstellation her - Rat und Geistlichkeit disputieren auf der Grundlage und nach den Kriterien des göttlichen Wortes - zugleich das innovative Moment der Züricher Disputationen betont; daran anschließend: Hollerbach (1982), 100-107.

9 | Fuchs (1995), 499-501, sieht in den Verhandlungen der Luthersache auf dem Wormser Reichstag von 1521 das humanistische Konzept des "synodalen Religionsgespräches" (501) verwirklicht, an dem sich in der Folgezeit vor allem die kaiserlichen Religionsgespräche orientierten. Bereits Hubert Jedin hatte die Religionsgespräche von den frühen Disputationen durch den Hinweis abgehoben, sie setzten "auf neugläubiger Seite konsolidierte Kirchengemeinschaften voraus, deren Rückgrat das Bekenntnis bildet" (Jedin (1958), 50).

10 | Vgl. Dingel (1997), 656, die daher auch den Ausdruck "Reformationsgespräche" zur Unterscheidung von den fürstlich und kaiserlich initiierten Religionsgesprächen gelten lässt.

11 | Zu den vorgestellten Gesprächen vgl. die Literaturangaben Dingel (1997), 675-681, sowie bei Scheib (2009/10), Bd. 3, 854-931. Die folgenden Anmerkungen benennen einschlägige Studien und machen darüber hinaus auf einige Neuerscheinungen aufmerksam. 
betrachtet werden. ${ }^{12}$ Fürstlicher Initiative dagegen verdankte sich das Leipziger Religionsgespräch von 1539, zu dem verschiedene humanistische Vertreter aus dem Bereich der Protestanten und Altgläubigen zusammenkamen und in dem nicht so sehr der dogmatische Konsens, als vielmehr eine gemeinsame Kirchenordnung gesucht wurde. ${ }^{13}$ Demgegenüber verfolgten dann die bekannten, vom Kaiser initiierten Gespräche zu Hagenau, Worms und Regensburg 1540/41 das Ziel eines Ausgleichs der Lehrgegensätze, wodurch Karl V. hoffte, die causa religionis klären zu können. ${ }^{14}$ Ebenfalls in einer kaiserlichen Initiative lag das zweite Regensburger Religionsgespräch von 1546 begründet, das freilich schon im Schatten der militärischen Vorbereitungen zur kriegerischen Lösung der Religionsfrage stand. ${ }^{15}$ Mit dem Wormser Gespräch von 1557, das auf eine Vereinbarung im Rahmen des sogenannten Augsburger Religionsfriedens von 1555 zurückging, kam die Linie der vom Kaiser initiierten Gespräche zu einem erfolglosen Ende. ${ }^{16}$ Einem von der Anlage her wesensverwandten Kolloquium in Poissy, mit dem 1561 ein konfessioneller Ausgleich innerhalb des französischen Königtums zwischen Katholiken und Hugenotten versucht wurde, war gleichfalls kein Erfolg beschieden, wenngleich die Hugenotten die Tatsache, dass sie erstmals als Dialogpartner der gallikanischen Kirche fungierten, mit einem gewissen Recht als einen Akt politischer Anerkennung verbuchen konnten. ${ }^{17}$

Der Augsburger Religionsfriede fixierte faktisch die Bikonfessionalität im Alten Reich, konzedierte das ius reformandi allerdings nur dem Landesherrn. Religionsgespräche boten sich unter diesen Voraussetzun-

12 | Immenkötter (1973); Decot (1989); Honée (1993); Immenkötter/Wenz (1997).

13 | Vgl. Fraenckel (1965), 14; Wartenberg (2001).

14 | Grundlage sind jetzt die in der Reihe "Akten der deutschen Reichsreligionsgespräche im 16. Jahrhundert" edierten Materialien: Ganzer (2000); Ganzer (2002); Ganzer (2007). Zu den Vorgängen im Einzelnen vgl. zur Mühlen (2005), 319-334; Luttenberger (1988), 65-101; Remy (1994), 29-49; Lexutt (1996); Augustijn (2001), 25-39; Lane (2004), 163-190; Stolk (2004); van Veen (2005), 40-45; Ganzer (2009), 99-133; Janssen (2009); Schultheis (2012).

15 | Vogel (2009).

16 | von Bundschuh (1988); Slenczka (2010).

17 | Nugent (1974); Dufour (1980), 117-126; Reinhard (1980), 89-116; Olson (2009), 227-238. 
gen als religionspolitisches Instrument fürstlicher Herrschaft an, sei es, dass evangelische Fürsten die innerprotestantischen Divergenzen zwischen Lutheranern und Calvinisten zu überwinden suchten wie im Maulbronner Religionsgespräch von $1564^{18}$, im Kolloquium von Mömpelgard $1586^{19}$ oder im Kolloquium von Sandomierz $1570^{20}$, wo innerhalb des polnischen Protestantismus ein »Consensus « zwischen Lutheranern, Calvinisten und den Böhmischen Brüdern gelang. Sei es, dass man innerlutherische Lehrgegensätze im eigenen Territorium zu überwinden hoffte - wie in Kursachsen im Religionsgespräch zu Altenburg 1568/69 oder Quedlinburg 1583. ${ }^{21}$ Sei es, dass man deviante Strömungen in die eigene Konfession $\mathrm{zu}$ integrieren suchte - wie bei den insgesamt allerdings eher selten unternommenen Versuchen eines Religionsgesprächs zwischen Lutheranern und Täufern. Bekannt ist hier vor allem das Religionsgespräch zu Frankenthal, das der pfälzische Kurfürst Friedrich der Fromme (1515-1576; 1559) im Jahr 1571 veranstaltete. ${ }^{22}$ Sei es aber auch, dass man mit Religionsgesprächen die Absicht verband, protestantische Vertreter zur Rückkehr zum Katholizismus zu bewegen - wie etwa in den Religionsgesprächen zu Baden-Baden und Emmendingen 1589/9023 oder besonders prominent, aber hier vom zeitlichen Rahmen her freilich außer Acht zu lassen, im Regensburger Religionsgespräch von $1601{ }^{24}$

In den Gesprächen, seien sie nun vom Kaiser oder den Fürsten angestoßen, ging es im Sinn der oben genannten Definition stets um eine Überwindung innerchristlicher, konfessioneller Gegensätze - eine Herausforderung, an der alle Gespräche, so unterschiedlich auch ihre jeweilige Konstellation gewesen sein mag, scheiterten, wenngleich auch etwa der Konsens in Teilaspekten gelang, am weitreichendsten vielleicht noch im Consensus von Sandomierz. Doch den verließen die polnischen Luthe-

18 | Brand (2000), 58-84.

19 | Raitt (1993).

20 | Bartel (1973), 107-128; Wrzecionko (1980), 145-152; Wrzecionko (1987), 26-41; Hein (2001), 425-431; Petkunas (2009), 317-346.

21 | Neuere Untersuchungen fehlen.

22 | Hege (1908); Greulich (1953); Güss (1960); Schmidt (1973), 58-64.

23 | Steigelmann (1970). Zur Rolle des mehrfachen Konvertiten Johannes Pistorius Niddanus d.J. in den Religionsgesprächen vgl. jetzt Moser (2009), 73-78.

24 | Herbst (1928); Münch (2004), 97-116. 
raner wieder, sobald der Rückhalt im deutschen Philippismus schwand, ${ }^{25}$ sodass auch dieses Colloquium das Ziel einer dauerhaften Angleichung oder Neutralisierung der innerchristlichen Lehrgegensätze nicht erreichte.

\section{Vorstellungen des Gelingens}

Bevor ich nach den Ursachen dieser beachtlichen Misserfolgsgeschichte frage, ist zunächst ein Blick auf die mit den Gesprächen verbundenen Vorstellungen des Gelingens zu werfen. »Wenn wir keine Vorstellung vom Gelingen eines Lebensentwurfs haben, dann sehen wir uns auch nicht als Gescheiterte. ${ }^{26}$ Das Diktum des Tübinger Sozialethikers Dietmar Mieth formuliert eine Voraussetzung, die auch für die Selbst- und Fremddeutung des Scheiterns im Kontext des 16. Jahrhunderts zutreffen dürfte. Meines Erachtens wären die Gespräche von den damaligen Zeitgenossen schwerlich als »gescheitert« beurteilt worden, wenn nicht mit ihnen bestimmte Erfolgsphantasien oder - vorsichtiger formuliert - bestimmte Erfolgshoffnungen verbunden gewesen wären, die sich dann aber offenbar samt und sonders zerschlugen.

Die Initiatoren der Gespräche, Kaiser und Fürsten, aber auch nicht wenige Theologen und Juristen verbanden damals mit den solchermaßen institutionalisierten Formen des binnenchristlichen Dialogs die Hoffnung auf eine Überwindung der konfessionellen Differenzen. Charakteristischer Ausdruck dieser Erwartungshaltung ist in den Quellen der Begriff der »Vergleichung « ${ }^{27}$. Bereits im Zusammenhang des ersten, inof-

25 | Wrzecionko (1980), 152.

26 | Mieth (1990), 386.

27 | Deutsches Wörterbuch von Jakob und Wilhelm Grimm, Bd. 25, 1999, 458, und die dort zum Lemma "Vergleichung" unter 1) "der ausgleich, vertrag" genannten Beispiele. Siehe weiter etwa die Formulierungen des Frankfurter Anstands von 1539 bei Neuser (1974), 75: "[...] damit ainmal der gantz nachtailig zwispalt in unserer hailigen religion in christenlich ainigkait und vergleichung gebracht, [...].«; ebd., 78: "[...] Daß in der religion als der rechten hauptsach ain gut christlich und entlich vergleichung gemacht werde, [...]." Die Einladung Karls V. zu einem Religionsgespräch vom 18. April 1540, ebd. 86: "[...] das zů schleuniger frydtlicher hinlegung und vergleiychung angereygter religionsachen ersprießlich sein mogte, 
fiziellen Religionsgesprächs im Rahmen des Augsburger Reichstages von 1530 waren die Vertreter der protestantischen Stände angewiesen worden, sich mit den übrigen Ständen des Reiches »zu vergleichen «. ${ }^{28}$ Zwei in religiösen Fragen dissentierende Partner zur Übereinstimmung bringen mit dem Ziel der Überwindung des Streites und der Wiederherstellung der Einigkeit ${ }^{29}$ (concordia) - damit dürften die Vorstellungen des Gelingens seitens der Initiatoren im Blick auf das Unternehmen »Religions-

[...]." Siehe auch die "Vorrede an den Christlichen Leser" in dem von Johannes Brenz herausgegebenen Protocoll Das ist/Acta oder Handlungen des Gesprechs/ zwischen den Pfältzischen vnd Wirtembergischen Theologen/von der Vbiquitet oder Allenthalbenheit des Leibs Christi/vnd von dem buchstäbischen verstand der wort Christi/Das ist mein Leib/etc. Im April des Jars 1564. zu Maulbrun gehalten. [...], Heidelberg 1565, fol. aij': "Nachdem die durchleuchtigste/durchleuchtige Hochgeborne Chur vnd Fürsten/Herr Friderich Pfaltzgraue bey Rhein/ [...] Auch Herr Christoff Hertzog in Wirtemberg vnnd Graue zu Mumpelgard/vnsere genedigste vnnd genedige Herren/auß Christlichem wolmeinenden eiver vnd gemüt/zu befürderung Göttlicher warheit/Auch pflantzung vnd erhaltung Gottseliger einigheit/des verschienen 64. jars/im Aprill/sich freundlich verglichen/ein Christliches gesprech von etlichen jetzt ein zeitlang streittigen Religionspuncten/[...] fürgehen zulassen/vnd wo möglich/eine Christliche vergleichung zutreffen/[...]." Lateinische Äquivalente des deutschen Ausdrucks sind unter anderem "concordia" oder "consensio «; siehe [Johannes Brenz,] Protocollum hoc est, Acta Colloqvii Inter Palatinos Et VVirtebergicos Theologos, de Vbiquitate siue omnipraesentia corporis Christi, Et de sensu verborum Christi, Hoc est corpus meum, \&c. Anno M. D. LXVIII [sic!]. Mulbrunnae habiti. [...], Heidelberg 1566, fol. aij'; Bucer, Acta Colloqvii In Comitiis Imperii Ratisponae Habiti, Hoc Est Articvli de religione conciliati, \& non conciliati omnes ut ab Imperatore Ordinibus Imperij ad iudicandum, \& deliberandum propositi sunt. [...], Straßburg 1541, fol. [Av] ${ }^{r}$.

28 | Dem tetlebenschen Protokoll zufolge wurde den protestantischen Fürsten vom Kaiser die Aushändigung einer Abschrift der Confutatio mit der Auflage in Aussicht gestellt, "das ßey sich darinne haben zu ersehen und sich mydt ierer Majestät und Kurfürsten und Fürsten und andern stenden des heiligen reichs vergleigen mügen“ (von Tetleben (1958), 101).

29 | Die Begriffe "Vergleichung" und "Einigkeit" konnten geradezu synonym gebraucht werden; siehe Philipp Melanchthon, Alle Handlungen die Religion belangend/so sich zu Worms/vnd Regensburg/auff gehaltenem Reichstag/des M.D.XLI. jars zugetragen/[...], Wittenberg 1542, fol. *iiiv: "Nu hat sich in der Kirchen solche 
gespräch« zutreffend umrissen sein. Man hoffte, durch das Gespräch eine Einigung unter den Kontrahenten herbeiführen zu können - nicht zuletzt um eine gewaltsame Lösung des Konflikts zu vermeiden. Frieden, Ruhe, Wohlfahrt, Einigkeit ${ }^{30}$ - das sind die in den Ausschreibungen immer wieder beschworenen Werte, denen der religiöse Vergleich dienen sollte. Wie sich die Initiatoren den Weg zur concordia konkret vorstellten, ließen sie offen. Ihnen ging es vorrangig um eine möglichst rasche Überwindung der konfessionellen Lehrgegensätze und die Wiederherstellung der »Eintracht«, mochte diese nun durch einen inhaltlichen Ausgleich, einen eher äußerlichen Kompromiss oder eine Konversion, einen Übergang des einen Teils zum anderen, erreicht werden. ${ }^{31}$ Martin Bucer, einer der führenden Theologen im protestantischen Lager, konnte im Vorwort zu seinem Bericht über das Hagenauer und Wormser Religionsgespräch von 1540 formulieren, dass »alles an vergleichung der Religion gäntzlich hanget, und on die beyde die spaltung vnnd undergang aller gůten polici bei vns vnnd der vnfall und niderligen gegen dem Türcken auffs gefährlichst zůnimmet, [...].«2 Mit den durch die konfessionellen Streitigkeiten heraufbeschworenen, innen- wie außenpolitischen Destabilisierungsge-

weltliche weisheit mehrmals erzeigt/mit gleissenden deutungen zu lencken/dadurch vergleichung vnd einigkeit zu machen/[...]."

30 | Einladung Kaiser Karls V. zu einem Religionsgespräch an die Protestanten, 18. April 1540: "[...] zů ruhe und wolfart gnadiglich gern gefurdert sehn [...]." (Neuser (1974), 86); Hagenauer Abschied, 28. Juli 1540: "[...] alwegen den frieden, rhue und ainigkhait im Heiligen Reich zephlantzen und zufurdern begirig gewest, [...]." (ebd., 96) Das Ausschreiben des Wormser Gesprächs und des Reichstages zu Regensburg, 15. August 1540 (ebd., 108-109): "[...] der gnedigen zuversicht, die sach mit gottlicher hilf so verhandlen zu lassen und zu furderen, damit man volgendts desto statlicher zu christlicher ainigkait und vergleichung komen und dardurch das sorglich mistrauen, so dieses zwißpalts halben zwischen den stenden des heiligen Reichs eingefallen, widerumb aufgehebt, auch im Heiligen Reiche fried und ainigkeit gepflanzt, und alsdan in anderen obligen notwendige handlung furgenomen werden möcht."

31 | Wie im nächsten Abschnitt deutlich wird, konnten mit einem Religionsgespräch auch Ziele verfolgt werden, die nur bedingt der dem Begriff des Vergleichs zugrundeliegenden Vorstellung einer Wiedergewinnung von Einheit entsprachen.

32 | Bucer, Alle Handlungen vnd Schrifften/zů vergleichung der Religion/durch die Key[serliche]. Mai[estät]/Churfürsten/Fürsten/vnd Stände/aller theylen/ 
fahren hat Bucer die beiden wichtigsten Beweggründe für die Durchführung solcher religiösen Vergleichsgespräche benannt. ${ }^{33}$ Daneben konnten auch rein binnenchristliche Motive wie etwa ein proto-ökumenischer Einheitsgedanke treten, wenngleich derlei Ideen im Reformationsjahrhundert eher selten begegnen und man nicht der Versuchung erliegen sollte, Vorstellungen aus der ökumenischen Diskussion des 20. Jahrhunderts ins 16. Jahrhundert zurückzuprojizieren.

\section{URSACHen des Scheiterns}

Was aber waren die Ursachen dafür, dass sich die vom Kaiser und von den Fürsten mit den Religionsgesprächen verbundenen Konkordienerwartungen nicht erfüllten? Warum kamen die obrigkeitlich initiierten Religionsgespräche - von Teileinigungen abgesehen - insgesamt nicht zum Ziel? Ich möchte im Folgenden einige Faktoren benennen, die meines Erachtens als Antwort auf die Fragen und damit zugleich als Deutung dieses auffallenden Phänomens des Scheiterns diskutiert werden können.

\section{1) Divergente Zielvorstellungen}

Anders als die soeben von der Wortbedeutung des »Vergleichs« abgeleiteten Hoffnungen auf Übereinstimmung nahelegen, waren die mit den Religionsgesprächen verfolgten Ziele faktisch vielfältiger. Gerade altgläubige Politiker und Theologen zögerten, dem kaiserlichen Wunsch nach einem Religionsgespräch überhaupt nachzukommen. Darauf einzugehen, hätte ja bedeutet zuzugeben, dass die Religionsfrage offen sei - ein Eingeständnis, zu dem die Wenigsten bereit waren. Sie betrachteten Luther und seine Anhänger vielmehr seit der Exkommunikation und Ächtung durch den Wormser Reichstag im Jahr 1521 als rechtsgültig verurteilte Ketzer. Die altgläubigen Theologen vollzogen daher auf dem Augsburger Reichstag 1530 nur sehr zögerlich und aufgrund politischen Drucks den Schritt,

Auch den Päbst[lichen] Legaten/auff jüngst gehaltnem Reichstag zů Regenspurg/ verhandlet/vnd einbracht/Anno D.M.XLI. [...], Straßburg 1542, fol. §ii .

33 | Die religiösen Spannungen drohten insbesondere die Reichsverwaltung und Reichsjustiz und damit letztlich die Autorität des Kaisers in Deutschland infrage zu stellen; vgl. Ziegler (1992), 24. 
in Ausgleichsverhandlungen mit den Protestanten einzutreten. ${ }^{34}$ Für sie konnte es dabei eigentlich nur das Ziel der Unterwerfung unter die römische Kirche geben. ${ }^{35}$

Oder aber man verwies auf das Konzil, das über die Fragen christlicher Lehre und Lebens zu entscheiden habe. So stand etwa das zweite Regensburger Religionsgespräch 1546 unter keinem günstigen Stern, weil die Vertreter der katholischen Seite mit der festen Absicht in die Donaustadt kamen, das Gespräch mit dem Verweis auf die Zuständigkeit des Konzils zu blockieren. ${ }^{36}$ Ähnlich stellte sich beim Religionsgespräch zu

34 | Eine Rolle spielte dabei auch der Umstand, dass an den Religionsgesprächen mitunter Politiker und Juristen teilnahmen, denen als Laien die Disputation von Glaubensfragen verboten war. Das häresierechtliche Dekretale Papst Alexanders IV. (1254-1261) formulierte weitreichend, Sexti Decretalium Liber V, Titulus II, Caput 2, §1 (Corpus luris Canonici, ed. Friedberg, Bd. 2, 1881, 1070): „Inhibemus quoque, ne cuiquam laicae personae liceat publice vel privatim de fide catholica disputare. Qui vero contra fecerit, excommunicationis laqueo innodetur." ["Wir verbieten auch (die Ansicht), dass es irgendeiner Laienperson erlaubt sei, öffentlich oder privat über den katholischen Glauben zu disputieren. Wer aber zuwiderhandelt, wird mit dem Fallstrick der Exkommunikation gebunden."]

35 | Janssen (1899), 504 überliefert ein Diktum Ecks aus dem Jahr 1541: „Da ist kein Mittel und helfen keine Worte; wer sich vereinigen will im Glauben mit der römischen Kirche, muß den Papst annehmen und die Konzilien und glauben, was die römische Kirche glaubt. Alles andere ist Wind, und wenn man hundert Jahre disputieren würde." Das Zitat wurde ohne Nachweis übernommen von Lortz (1982), Bd. 2, 230. Die Angaben bei Janssen (Codex Trierer Sachen und Briefschaften, aus dem Nachlaß des Xantener Canonicus Pelz; vgl. ders., Geschichte des deutschen Volkes seit dem Ausgang des Mittelalters, Bd. 22: 1897, 19, Anm. 2) wurden nicht überprüft. Der Sache nach bestätigt freilich auch Bucer diese Position Ecks: "Als bayde theil zůsammen kommen/hat Doctor $\mathrm{H}$. Eck disen eingang gemacht/Ich vnd mein mit verordnete wolle vns nicht darumb mit eüch in einigem stuck ze weichen/ sonder allein darumb/das wir vndersthon wöllenn/eüch wider zů vns/vnd zur alten gehorsam der Kirchen zů bringen." (Martin Bucer, Vom tag zu Hagenaw vnd wer verhinderet hab/das kein gesprech von vergleichung der Religion daselbst fürgangen ist. [...], [Straßburg] 1540, fol. Aiij') Zum Entstehungshintergrund der Augsburger Gespräche vgl. Immenkötter (1981), 32-41.

36 | Nicht nur die streng altgläubige Gruppe der Reichsstände um Herzog Wilhelm IV. von Bayern (1493-1550; 1508) lehnte den neuerlichen Versuch eines 
Poissy der Jesuitengeneral Diego Laínez (1512-1565) auf den Standpunkt, dass die weltliche Autorität zur Klärung religiöser Streitfragen gar nicht ermächtigt sei und die Gesprächsrunde mithin keine Entscheidungskompetenz in diesen Fragen habe. ${ }^{37}$ Es bedarf keiner größeren historischen Einbildungskraft, um sich vorzustellen, dass von solchen Überzeugungen der Illegitimität religiöser Gespräche aus ein konstruktiver Dialog mit den Protestanten schwerlich möglich war.

Umgekehrt konnten protestantische Teilnehmer mit dem Ziel einer Demonstration evangelischen Glaubens in die Verhandlungen mit den Katholiken hineingehen. Calvin formulierte in einem Brief an den Baseler Prediger Simon Sulzer (1508-1585) im Blick auf die Verhandlungen von Poissy unzweideutig: »Mit den Papisten müssen wir kämpfen. « ${ }^{38}$ Auch wenn er nicht selber zum Gespräch eingeladen war, sondern der offenbar als nachgiebiger eingeschätzte Theodor Beza (1519-1609), so verband sich doch bei Calvin damit die Hoffnung, durch eine Darlegung der evangelischen Lehre vor dem Königshaus die französische Krone für den Protestantismus zu gewinnen. ${ }^{39}$ Ziel war hier also nicht der religiöse Ausgleich und mithin die Annäherung der eigenen Position an diejenige des römischen Katholizismus, sondern eher in der Tradition der städtischen Reformationsgespräche die Überwindung des Gegners durch die evangelische »Wahrheit «. ${ }^{40}$ Analog traten auch bei dem innerprotestantischen Religionsgespräch, das die Württemberger Theologen in Maul-

Religionsgesprächs mit den Protestanten ab; Karl V. selbst hatte den Delegierten des kaiserlichen Hofes zunächst die Instruktion gegeben, die Gespräche scheitern zu lassen; vgl. Vogel (2009), 65-72, 285-286, 489.

37 | Vgl. Nugent (1974), 154-155.

38 | CR 46, 629, Nr. 3489 (Johannes Calvin an Simon Sulzer; [Genf?], 23. August 1561): "Cum papistis confligendum est." Ähnliche Zielvorstellungen verband Calvin bereits als Straßburger Delegierter mit den Religionsgesprächen von Hagenau, Worms und Regensburg; vgl. Ortmann (2010), 35-54.

39 | Vgl. Dufour (1980), 117; Nugent (1974), 182.

40 | Die Zielvorstellung der Glaubensdemonstration scheint typisch für die Gespräche nach dem Augsburger Religionsfrieden zu sein. Da der Zwang, die politische Einheit durch die religiöse Einheit herzustellen, weggefallen war, traten jetzt zumindest bei den Reichsreligionsgesprächen andere Absichten in den Vordergrund (Selbstvergewisserung, Propaganda, Mission, Ausgrenzung); vgl. Hollerbach (1982), 259. Dass daneben aber auch noch nach wie vor Religionsgespräche mit 
bronn 1564 mit den sich reformierten Einflüssen öffnenden Pfälzer Theologen oder 1586 mit den Genfer Theologen in Mömpelgard führten, Ziele der Überzeugung, ja Überwindung des Gegners in den Vordergrund. ${ }^{41}$ Derlei Leitvorstellungen zeigen nicht nur den lange nachwirkenden Einfluss der Disputatio, des geradezu klassisch-scholastischen Instruments zum kommunikativen Austrag kontroverser Standpunkte. Sie lassen auch erkennen, wie weit entfernt hier noch aufklärerische Toleranzgedanken sind: Die religiöse Wahrheit kann letztlich nur eine sein - und man weiß sie in der eigenen Konfession auf seiner Seite. Allerdings konnten Zieldivergenzen auch im Lauf der Gespräche überwunden werden - wenigstens bis zu einem gewissen Grad. Wie etwa die Ausgleichsverhandlungen im Zusammenhang des Augsburger Reichstages von 1530 erkennen lassen, wurden die anfänglichen Vorbehalte der altgläubigen Theologen, insbesondere Johannes Ecks, nicht zuletzt durch kaiserlichen Druck aufgeweicht. Eck ließ sich daraufhin auf das Ziel eines Ausgleichs ein. ${ }^{42}$ Wo eine solche Angleichung unterschiedlicher Zielvorstellungen nicht gelang, war das Gespräch zum Scheitern verurteilt.

dem Ziel einer religiösen Einheit - als Voraussetzung der politischen Einheit - gesucht werden konnten, beweisen die innerprotestantischen Religionsgespräche.

41 | Siehe zum Maulbronner Religionsgespräch etwa die Vorreden in Brenz (1566), fol. aij '-cij ${ }^{\mathrm{V}}$. Bemerkenswert auch die Vorrede Graf Friedrichs I. von Mömpelgard (1557-1608) zur Edition der Gesprächsakten des Mömpelgarder Religionsgesprächs, in der Friedrich unverholen erklärt, dass durch das Gespräch die Wahrheit des eigenen lutherischen Bekenntnisses erwiesen sei und den Reformierten Frieden unter der Bedingung der Annahme dieser "Wahrheit" angeboten werden könne: "Vnd weil in diser Handlung die Warheit vnser Christlichen Bekantnus liecht vnd hell angezeigt/vnnd an Tag gethan worden/so ist hiemit vnserm Gegentheil ein warhafftiger beständiger vnd Gott wolgefälliger Friden angebotten/ welcher gantz leichtlich kan getroffen werden/wann sie die Göttliche Himmlische Wahrheit/so im Wort Gottes begriffen vnd außgetruckt/mit vns einhellig vnd einmütig annemen wöllen/welche wir ihnen von Hertzen wünschen/[...]." ([Jacob Andreae,] Colloqvium Mompelgartense. Gespraech/Jn gegenwart des Durchleuchtigen [...] Herrn Friderichen/Grauen zu Wuertemberg vnd Muempelgart/etc. [...] Zwischen den Hochgelehrten/D. Iacobo Andreae, Propst vnd Cantzler der Hohen Schul zu Tuebingen/vnnd D. Theodoro Beza, Professorn vnd Pfarrern zu Genff. [...], Tübingen 1587, fol.):():([iiij] $\left.]^{v}\right)$.

42 | So die These Albrecht P. Luttenbergers in ders. (1988), 192-222. 


\section{2) Fehlende Kompromissbereitschaft}

Dieser Punkt hängt mit den Zielvorstellungen zusammen, ist aber davon noch einmal zu unterscheiden. Denn selbst wenn man sich ernsthaft auf das Ziel des Ausgleichs einließ, scheiterte das Gespräch oft an der mangelnden Bereitschaft, ja teilweise auch Fähigkeit zum Kompromiss. Wo die Gesprächsteilnehmer sich außerstande sahen, wenigstens den Versuch zu wagen, die eigene Position so zu reformulieren, dass sich das Gegenüber darin wiederfinden konnte, musste das Gespräch im Sand verlaufen. Um angesichts der inhaltlichen Differenzen überhaupt weiterzukommen, war die Bereitschaft zum positionellen Kompromiss nötig. Diese konnte sich etwa darin äußern, dass man bereit war, zwischen dem nach eigenem Verständnis zum Seelenheil unverzichtbar Notwendigen und dem eher äußeren, auf menschlicher Konvention Beruhenden zu unterscheiden. ${ }^{43}$ Wurde eine solche Unterscheidung verweigert und beschwor jeder Gesprächspunkt den status confessionis herauf, gab es kaum Spielräume zur Verständigung. Sie konnte sich aber auch darin äußern, die eigene Position von den als verbindlich behaupteten theologischen Quellen her hinterfragen und gegebenenfalls revidieren zu lassen. Doch war in den altgläubig-protestantischen Gesprächen die Frage der theologischen Quellen selbst bereits mehr oder weniger ausgesprochen kontrovers: Sollte nur die Schrift als normative Grundlage gelten, oder waren mit ähnlichem Gewicht auch die Kirchenväter und altkirchlichen Konzilien zu berücksichtigen? ${ }^{44}$

43 | Selbst die Vertreter der Kurie waren in dieser Hinsicht meistens zu partiellen Zugeständnissen bereit; vgl. Lortz (1982), 228-229.

44 | Siehe die nüchternen Bemerkungen Johannes Groppers in dessen Gutachten zum Passauer Vertrag für Adolf von Schaumburg, Erzbischof von Köln: "Ad haec frustra fit congressus cum adversariis. Catholici enim ab ecclesiastica scripturarum interpretatione et traditione recedere non possunt. Has autem adversarii non admittunt, sed scripturis a se excogitatas interpretationes quamvis coactas inferunt." ["Dazu geschieht die Zusammenkunft mit den Gegnern umsonst. Denn die Katholiken können von der kirchlichen Schriftauslegung und Tradition nicht weichen. Das aber werden die Gegner nicht zugestehen, sondern aus der Bibel ihre selbsterdachten, obgleich erzwungenen Auslegungen vorbringen."] (Schwarz (1886), 409). 
Die kaiserliche Politik suchte bei den altgläubig-protestantischen Verhandlungen tunlichst, die in diesem Sinne kompromissbereiten Vertreter beider Religionsparteien zusammenzuspannen. Sie setzte darauf, nicht die »Hardliner« der jeweiligen Lager, sondern Vertreter einer mittleren Linie ins Gespräch zu bringen. Aus dem Bereich der Altgläubigen waren das etwa Julius von Pflug (1499-1564), Johannes Gropper (1503-1559), Kardinal Gasparo Contarini (1483-1542), aus dem Lager der Protestanten vor allem Martin Bucer und Philipp Melanchthon. Es dürfte kein Zufall sein, dass diese Theologen allesamt mehr oder weniger vom Humanismus des Erasmus von Rotterdam geprägt oder wenigstens beeinflusst waren. Der Kaiser erhoffte sich offenbar gerade von den »Erasmus-Schülern« auf beiden Seiten eine Verständigung in den strittigen Fragen. Dass sich durch die humanistischen Kollokutoren tatsächlich Situationen der Annäherung ergeben konnten, zeigen manche Urteile zeitgenössischer Beobachter und Gesprächsteilnehmer. ${ }^{45}$

\section{3) Befangenheit in Wahrnehmungs- und Sprachmustern}

Der Kompromiss war indes nicht nur eine Frage des guten Willens. Er war nicht nur eine Frage der Bereitschaft zur Differenzierung oder zur Revision der eigenen Position durch die theologischen Quellen. Er war vor allem auch eine Frage der Wahrnehmung des Gegenübers. Diese stand freilich ungleich weniger in der Verfügung der Gesprächsteilnehmer.

Protestantische Vertreter waren oft nur in der Lage, die andere Seite von den eigenen rechtfertigungstheologischen Fragestellungen her wahrzunehmen. Altgläubige Gesprächspartner erfassten die protestantischen

45 | Siehe die Einschätzung des Regensburger Religionsgesprächs von 1541 durch Bucer (1542), fol. A[i] $]^{\mathrm{V}}-\mathrm{Aii}$ : "Vnnd inn dem anders nichts angesehen oder gesucht/dann das die frommen Christen Deutscher Nation/bede oberen vnd vnderthonen/hierin sehen/vnnd erkennen/wie nahe vns der liebe Gott zů zimlichem anfang einer seligen vergleichung der Religion/vnnd Reformation der Kirchen bracht/vnd gern gar dazu verholffen hette/so wir selbst gewölt [...]. "Bekannt ist auch das in seinem Quellenwert freilich nicht überzubewertende Diktum Luthers aus den Tischreden zu den Verhandlungen im Zusammenhang des Augsburger Reichstages von 1530, WATr 4, 495, 7-9, Nr. 4780: "Ich habe sorg, das wir nimer mehr so nahent zw samen khumen werden als zw Augspurg."Vgl. daran anschließend Immenkötter (1981), 41. 
Positionen selten anders als in den gewohnten Denkkategorien der scholastischen Schultheologien. Auch verlor man zunehmend die gemeinsame Sprache. »So war es schon seit den $20 e r$ Jahren, « resümiert Lothar Vogel, »zur Ausbildung zweier getrennter theologischer Diskurse und damit auch zu einem gegenseitigen Nichtverstehen bzw. auch Nichtverstehenwollen gekommen, weil zentrale Begriffe wie >Buße<, >Glaube $<$ oder >Gerechtigkeit< auf beiden Seiten unterschiedlich konnotiert waren. ${ }^{46}$ Nur gelegentlich gelang es den Gesprächspartnern, die eigenen Sprachmuster zu erkennen und zu überschreiten. Ironischerweise konnten unerkannte Äquivokationen auch zu Einigungsfeststellungen führen, die in Wahrheit keine waren. So wurde gegnerischen Artikeln oder auch Kompromissformeln zugestimmt, weil man wie selbstverständlich vom eigenen Begriffsverständnis ausging. Dass etwa in der scheinbaren Übereinstimmung in der Rechtfertigungslehre, die man im Anschluss an den Augsburger Reichstag von 1530 gefunden $\mathrm{zu}$ haben glaubte, ein jeweils unterschiedliches Verständnis von fides vorausgesetzt war, erkannte man erst später. ${ }^{47}$ Die Verständigungsmöglichkeiten im Rahmen der Religionsgespräche wurden durch die Tatsache, dass die Teilnehmer den vertrauten Wahrnehmungs- und Sprachmustern verhaftet blieben, nicht unerheblich eingeschränkt. ${ }^{48}$

46 | Vogel (2009), 519. Die unterschiedlichen Konnotationen werden unter anderem daran sichtbar, dass bestimmte Begriffe, welche die Gegenseite als Äquivalente angibt, abgelehnt werden; siehe etwa Melanchthon (1542), fol. CLXVII': "Als/da er [scil. Johannes Eck, M.N.] fur das wort/Sünde oder gebrechen/davon wir sagen/das solches den Heiligen vergeben vnd nicht zugerechnet werde/gefehrlicherweise ander wort brauchet/vnd nennets etwa/Crimen/ein öffentliche vntugent/etwa Capitale peccatum/eine Heubtsünde/etwa Culpa/eine Schuld/So doch vnter diesen eine grosse vnterscheid ist/[...]." Aufschlussreich sind in diesem Zusammenhang auch die Bemerkungen Martin Bucers zum Verständnis der fides viva et efficax des Regensburger Buches; siehe Bucer (1542), fol. 101 ${ }^{\mathrm{v}}-102^{\mathrm{r}}$. 47 | Vgl. Immenkötter (1981), 35-36; Fuchs (1995), 373-375.

48 | So sieht etwa Karl-Heinz zur Mühlen im Blick auf das Regensburger Religionsgespräch die Verständnisbemühungen Groppers und Contarinis durch einen aristotelischen "Denkhorizont" begrenzt; vgl. zur Mühlen (1979), 355. 


\section{4) Unüberbrückbare inhaltliche Differenzen}

Während über die formalen Fragen zur Art und Weise des Vorgehens (modus procedendi) oder zur literarischen Gesprächsgrundlage oft noch eine Einigung erzielt werden konnte, war dies bei den inhaltlichen Fragen ungleich schwieriger. ${ }^{49}$ Hier tat sich ein breites Spektrum an Divergenzen auf, von der eher praktischen Ordnung kirchlichen Lebens bis hin zu diffizilen material-dogmatischen Lehrbildungen (wie der Rechtfertigungslehre oder des Abendmahlsverständnisses). Dabei erwiesen sich in den altgläubigprotestantischen Gesprächen die Fragen kirchlicher Praxis - wie etwa die Einführung des Laienkelches, die Zulassung der Priesterehe, die Abschaffung der Bilderverehrung - teilweise problematischer als die Fragen der Lehre selbst. Der Erfolg eines Ausgleichskonzeptes hing entscheidend von der Qualität der inhaltlichen Differenzen ab. Es gab Themenbereiche, in denen sich die Positionen nicht oder nur minimal unterschieden (Trinität, Taufe). Es gab andererseits Themenbereiche, in denen teilweise gegensätzliche Positionen vertreten wurden (Buße, Amt, Kirchenverständnis). Beide Seiten gingen indes unhinterfragt von der Voraussetzung aus, dass es in Fragen der Religion nur eine Wahrheit geben könne.

Wie suchten die Kollokutoren diese im Einzelnen recht unterschiedlichen Differenzen auszugleichen? Folgende Strategien lassen sich feststellen:

1. Man versuchte eine Synthese der unterschiedlichen Standpunkte. Am eindrücklichsten gelang das wohl in den Fragen der Rechtfertigungslehre auf dem Regensburger Religionsgespräch von 1541. Dort erarbeitete man eine Formel, der das Modell einer »doppelten Gerechtigkeit« (duplex iustitia) zugrunde lag, mit dem man sowohl den lutherischen Gedanken einer Gerechtmachung des Sünders »allein durch Gnade« (sola gratia) als auch den von den altgläubigen Theologen favorisierten Gedanken eines durch die Gnade bewirkten Wachstums in der Gerechtigkeit verbinden wollte. ${ }^{50}$

49 | Gelegentlich scheiterten die Gespräche allerdings auch schon an Verfahrensfragen; vgl. Honée (1985), 195-216.

50 | Die Regensburger Rechtfertigungstheologie hat die Aufmerksamkeit der Forschung seit längerem auf sich gezogen; vgl. Stupperich (1939), 88-116; zur Müh- 
2. Oder man versuchte, eines der beiden vorgetragenen Konzepte als unhaltbar auszuscheiden, sei es, dass man Widersprüche sichtbar machte, sei es, dass man Spannungen zu den jeweils behaupteten theologischen Quellen - Bibel, Kirchenväter, Konzilien - aufwies. Diese Strategie, die das Religionsgespräch wieder der Form der disputatio annäherte, verfolgten etwa die kurpfälzischen Theologen in ihren Kolloquien mit den Täufern. Die Gespräche hatten das mehr oder weniger unausgesprochene Ziel, die Unhaltbarkeit der täuferischen Theologie zu erweisen, um die Täufergruppen, so die Hoffnung, zur Konversion zu bewegen und mithin wieder in die kurpfälzische Kirche zu integrieren. ${ }^{51}$ In den altgläubig-protestantischen Verhandlungen wurde diese Strategie in den Religionsgesprächen dagegen kaum offen verfolgt. Sie blieb eher eine heimliche Anfechtung, der man sich - auf beiden Seiten - nicht immer zu entziehen vermochte.

3. Schließlich gab es noch die Möglichkeit, und sie wurde in den weitaus meisten Fällen verfolgt, die beiden unterschiedlichen Positionen zugleich bestehen zu lassen. Das konnte zum Beispiel dadurch erreicht werden, dass man einen Konsenstext formulierte, in dem sich beide Seiten mit ihren Positionen cum grano salis wiederfinden konnten. Oder durch den Versuch, die andere Position als Ausnahme von der eigenen »Regel« zuzulassen oder sogar - noch weitergehend - die eigene Position als Ausnahme von der »Regel« der anderen Position

Ien (1969), 176-194; von Loewenich (1972); Braunisch (1974); zur Mühlen (1979); Martens (1992); Lexutt (1996).

51 | Kluckhohn (1870), Bd.2/1, 410 (Kurfürst Friedrich III. an Herzog Johann Friedrich den Mittleren; Heidelberg, 17. Januar 1571): "Die ursach aber, so mich bewogen, das ich gegen diesen buben [scil. die Täufer, M.N.] das colloquium angestellt, ist diese, das sie mir meyner underthanen vil an sich gehenckt und verführt, da ich dan zu Gott dem almechtigen tröstlicher hoffnung bin, wie ich auch bericht, das sich zum thayl zugetragen, etzlichen derselben die augen uffgangen, da sie gesehen und gehört, wie ungereumbt die bösen buben geantworth und sich Gottes worth mit dem wenigsten haben wollen weysen Iassen." Vgl. dazu Hege (1908), 119-120. Erhellend auch die Ausführungen des kurpfälzischen Juristen Wenzel Zuleger (1530-1596) zur Intention des Kurfürsten nach dem Protocoll. Das ist/Alle handlung des gesprechs zu Franckenthal inn der Churfürstlichen Pfaltz/ mit denen so man Widertäuffer nennet/Auff den 28. May angefangen/vnd den 19. Junij dises 1571. jars geendet. [...], Heidelberg 1571, 675-676. 
zu konzedieren. ${ }^{52}$ Diese Strategie ließ sich in den altgläubig-protestantischen Verhandlungen um so leichter verfolgen, als man zunächst immer noch auf die Zuständigkeit eines künftigen Konzils hinweisen und den Kompromiss als vorläufig deklarieren und damit zugleich rechtfertigen konnte. Mit dem Beginn des Trienter Konzils, das die Protestanten nicht als »christliches Konzil« akzeptieren konnten, ${ }^{53}$ waren derlei Konzessionen freilich keine ernsthafte Option mehr.

52 | Melanchthon gab in einem Gutachten vom 24. August 1530 zu den Verhandlungen des Vierzehnerausschusses in der Abendmahlsfrage Folgendes zu bedenken: "Der gegentayl arbet noch dahin, das wir leren wöllen, das auch recht sey ein gestalt zu gebrauchen, [...]: darauf bedenck ich, ob inen so ferren nachgeben: das wir leren wollten, das diejhenigen, so ain gestallt empfahen, nit vnrecht thun, die weil sy mussen das sacrament empfahen, wie es inen gereicht wirt vnd sie selbs nit haben administrationem sacramentorum. also ist plebs entschuldigt durch den casum necessitatis. daruber bekennen wir auch, das vrsach mögen gewesen sein, darumb diese gewonheit ein gestalt zu empfahen ohn sund eingefurt ist, welliche aber dieselben seien, stellen wir zu ferrer handlung in einem concilio. also sein die porrigentes nit damnirt auch nit approbirt, sondern solchs ist vffs concilium gestellt. das wir aber weitter sollten bekennen, das bede gestallt zu raichen nit preceptum sey, haben wir zuuor geantwort, es sey preceptum, doch dispensabile, wie andere ceremonialia darumb etwan ainich gestalt gepraucht mag werden, als mit schwachen, so nit wein trincken etc. oder sonst in gleichen fellen. so bekent der gegenteil selbs, das ain gestalt von der kirchen introducirt sey. darumb muss zuvor bede gestalt aus crafft der einsetzung christi gerecht sein, derhalben sie auch bekennen mussen, das bede gestalt ordinatio cristi sey, fur die gantzen kirchen nit allein fur die priester eingesatzt. das sy aber wollen, es sey doch nit preceptum, haben wir auch geantwort, es sey dispensabile. damit acht ich sollten sie zufriden sein." (zit.n. Schornbaum (1905), 144-145.)

53 | Siehe das Gemeinschaftsgutachten der Wittenberger Theologen Martin Luther, Johannes Bugenhagen, Caspar Cruciger und Philipp Melanchthon vom 8./9. Januar 1546, in dem das Trienter Konzil nicht zuletzt wegen des dominierenden Einflusses des Papstes abgelehnt wurde (CR 6, 8, Nr. 3352): "[...] es folge die Eröffnung des Concilii, oder nicht, so achten wir, daß nützlich sey ein christliche Recusation mit guten Grunden und Ursachen zu stellen, und die selbige an das Licht zu geben in Latin, Teutsch und Französisch, damit männiglich berichtet werde, warum dieses Consilium nicht allein nicht für unsre Richter, sondern auch für kein christlich Concilium zu halten, dieweil es der Bapst als Verfolger offentlicher 
Das mehr oder minder konsequente Befolgen der ersten und dritten Strategie führte im Rahmen des Wormser Gesprächs von 1541 zu Fortschritten: Die Zahl der unverglichenen Artikel konnte von 14 auf sechs herabgedrückt werden. ${ }^{54}$ In Regensburg 1541 gelang - in den Augen der Teilnehmenden - die lang ersehnte Einigung in der Rechtfertigungslehre, aber dann brach der Konflikt an anderer Stelle, in der Kirchenlehre und im Abendmahlsverständnis, ungleich heftiger auf.

\section{5) Delegationen ohne Vollmacht}

Doch selbst wenn es gelang, einen Konsens in den Fragen der Lehre und des kirchlichen Lebens zu erzielen, so war immer noch fraglich, inwieweit dieser Konsens von den jeweiligen Religionsparteien rezipiert wurde. Das Verhältnis der Kollokutoren zu den konfessionellen Gruppierungen, die sie vertraten, und insbesondere zu den »Autoritäten« dieser Gruppierungen war teilweise spannungsreich. In den Religionsgesprächen blieb häufig die Frage offen, inwieweit die Kollokutoren nur für sich selbst sprachen oder auch für die Gruppierung, die sie vertraten. Gerade die kaiserliche Religionspolitik, die auf das Gespräch scheinbar kompromissbereiter Theologen, Juristen und Politiker aus dem altgläubigen wie protestantischen Lager setzte, kaufte sich doppelte Schwierigkeiten in der Aufnahme der ausgehandelten Kompromisse ein. Zum einen: War ein Kompromiss in den altgläubig-protestantischen Ausgleichsverhandlungen eigentlich sein Papier wert, der ohne direkte Beteiligung des Papstes und nur durch mehr oder weniger bevollmächtigte kuriale Vertreter zustande gekommen war? ${ }^{55}$ In den altgläubig-protestantischen Verhandlun-

Wahrheit gubernirn, Richter darin setzen, Proceß ordinirn, schließen etc. wolle." Vgl. Stupperich (1956), 38. Zu Luthers wechselnder Einstellung gegenüber dem Konzilsgedanken vgl. jetzt Spehr (2010).

54 | Vgl. Lortz (1982), 233.

55 | Informativ sind in dieser Hinsicht die Korrespondenzen zwischen dem kaiserlichen Hof und der Kurie im Vorfeld des Regensburger Religionsgesprächs von 1541. Granvella drängte auf eine Entsendung eines päpstlichen Legaten mit möglichst umfassenden Vollmachten; der Papst entsandte mit Contarini dann auch einen förmlich als Legaten titulierten Vertreter, schränkte dessen Vollmachten aber bewusst ein, indem er darauf verwies, dass die Entscheidung in Glaubensdingen letztlich einem allgemeinen Konzil obliege. Damit war zugleich den Ver- 
gen blieb durch die nur teilweise Einbindung der Kurie der Grad der Offizialität unklar. ${ }^{56}$ Zum anderen wurden die Kollokutoren nicht selten mehr oder weniger öffentlich verdächtigt, um des vom Kaiser erwünschten Kompromisses willen die Lehren der eigenen Konfession preisgegeben $\mathrm{zu}$ haben. Politiker und führende Theologen der jeweiligen Konfessionsgruppe misstrauten oftmals den eigenen Delegierten und übten auf sie in Briefen gelinden Druck aus. ${ }^{57}$ Sie erwiesen damit die Gesprächsteilnehmer gewissermaßen als Bevollmächtigte ohne Vollmacht. Ein in seiner Spannung zwischen seelsorglichem Trost und konfessionspolitischer Instruktion aufschlussreiches Beispiel ist der Briefwechsel zwischen Luther und Melanchthon zur Zeit des Augsburger Reichstages von 1530. ${ }^{58}$

suchen auf protestantischer Seite, die vom Kaiser initiierten Gespräche als Form eines Nationalkonzils zu verstehen, eine klare Absage erteilt; vgl. Ganzer (2009), 99-133.

56 | Vgl. hinsichtlich der Augsburger Verhandlungen von 1530 Lortz (1982), 229: "Immerhin gab die Kurie zu dem ersten Religionsgespräch irgendwie ihre Zustimmung."

57 | Zur Politik der Kontrolle Kurfürst Johann Friedrichs von Sachsen gegenüber den eigenen Delegierten vgl. Ziegler (1992), 23.

58 | WABr 5, 405, 17-26, Nr. 1609 (Luther an Melanchthon; [Coburg], 29. Juni 1530): "Accepi Apologiam vestram, et miror quid velis, ubi petis, quid et quantum sit cedendum Pontificibus. De Principe est alia quaestio, quid illi concedendum sit, si huic periculum impendeat. Pro mea persona plus satis cessum est in ista Apologia, quam si recusent, nihil video, quid amplius cedere possim, nisi videro eorum rationes aut Scripturas clariores, quam hactenus vidi. Ego dies et noctes in ista causa versor, cogitans, volvens, disputans et totam Scripturam lustrans, et augescit mihi assidue ipsa $\pi \lambda \eta \varrho o \phi o \varrho i ́ \alpha$ in ista doctrina nostra, et confirmor magis ac magis, daß ich mir (ob Gott will) nu nichts mehr werd nehmen lassen, es gehe drüber, wie es wolle." ["Ich habe Eure Apologie erhalten und wundere mich, was Du willst, wenn Du fragst, was und wieviel den Päpstlichen nachgegeben werden solle. Was den Fürsten betrifft, ist das eine andere Frage, was er nachgeben solle, wenn inm Gefahr droht. Für meine Person ist in dieser Apologie mehr als genug nachgegeben worden; sollten sie diese zurückweisen, sehe ich nichts, was ich darüber hinaus nachgeben könnte, es sei denn, ich sähe von innen Beweise und klarere Schriftstellen, als ich sie bisher gesehen habe. Ich beschäftige mich Tag und Nacht mit dieser Sache, denkend, abwägend, erörternd und die ganze Schrift durchsuchend, und es wächst in mir beständig die Gewissheit in dieser unserer 
Faktisch offenbarte erst die Rezeption, was der Kompromiss wirklich wert war. Gerade das von den hier berücksichtigten Kompromisstexten her vielleicht ertragreichste Dokument, das Regensburger Buch von 1541, fand keine Resonanz, weil sich sowohl die altgläubigen Stände wie auch

Lehre und ich werde mehr und mehr darin bestärkt, [...]."] Luther sah sich in seiner grundsätzlichen Skepsis gegenüber einem "Vergleich" in der Religionsfrage durch den Fortgang der Augsburger Ereignisse bald bestätigt und vermochte den Gesprächen allenfalls noch als Demonstration evangelischer Wahrheit einen Sinn abzugewinnen. Ebd., 470, 1-10, Nr. 1642 (Luther an Melanchthon; Coburg, 13. Juli 1530): " Arbitror, te, mi Philippe, iam satis multa experientia videre, Belial nulla ratione cum Christo conciliari posse [vgl. 2 Kor 6,15 ], nec spem concordiae ullam concipi debere, quoad doctrinam. Scripsi de hoc ad Principem, causam nostram non posse ferre Caesarem iudicem. Et nunc quid literae citationis tam clementes voluerint, videmus. [...] At certe pro mea persona ne pilum quidem illis cedam, aut patiar restitui, potius extrema omnia expectabo, quando sic obstinate pergunt." ["Ich meine, dass Du, mein Philippus, schon aus genügend Erfahrung siehst, dass Belial in keiner Weise mit Christus versöhnt werden kann und dass man hinsichtlich der Lehre keinerlei Hoffnung auf Eintracht hegen darf. Ich habe darüber an den Fürsten geschrieben, dass unsere Sache nicht vor den kaiserlichen Richter getragen werden kann. Und jetzt sehen wir, was das so milde Einladungsschreiben zum Reichstag gewollt hat. [...] Aber ich für meine Person werde sicherlich auch kein Haarbreit nachgeben oder dulden, dass etwas wiederhergestellt wird; ich erwarte eher das Äußerste, wenn sie so hartnäckig weitermachen."] Unmissverständlich der Brief Luthers an Spalatin, ebd., 576, 13-16, Nr. 1698 (Luther an Spalatin; Coburg, 26. August 1530): "Audio vos non libenter sane inceptasse mirificum opus, scilicet concordandi papę \& Lutheri. Sed papa n̂olet \& Lutherus deprecatur; videte, ne operam pulchre luseritis. Quod si inuito vtroque rem perfeceritis, tum ego mox vestrum exemplum secutus, conciliabo Christum \& Belial! [vgl. 2 Kor 6,15]" ["Nicht gerne höre ich, dass Ihr ein wunderliches Werk begonnen habt, nämlich den Papst und Luther zu versöhnen. Aber der Papst will nicht und Luther verbittet sich das. Seht darauf, dass Ihr Eure Mühe nicht fein verspielt! Wenn Ihr die Sache gegen den Willen beider zu Ende bringt, dann werde ich umgehend eurem Beispiel folgen und Christus und Belial miteinander versöhnen!“] Siehe auch ebd., 578, 42-49, Nr. 1699 (Luther an Melanchthon; Coburg, 26. August 1530). Zu Luthers Coburg-Briefen vgl. die pointierte Deutung von Leppin (2010), 169-181. 
Luther dagegen aussprachen. ${ }^{59}$ Hier rächte sich die kaiserliche Strategie, auf die sogenannten Vermittlungstheologen zuzugehen und mit ihrer Hilfe eine Lösung der Religionsfrage jenseits des Konzils zu suchen. Der Vorteil, den die Wahl der Vermittlungstheologen aufgrund ihrer Kompromissbereitschaft für den Gesprächsverlauf mit sich brachte, wurde durch die begrenzte Akzeptanz eben dieser Theologen in den konfessionellen Referenzgruppen wieder infrage gestellt.

\section{SCHLUSSBEtRAChtUNG}

Die ermittelten Faktoren stellen den Versuch einer Typologie kausaler Deutungsmuster dar. Der abstrakte, gewissermaßen verallgemeinernde Charakter, der den Faktoren eignet, steht dem Ziel eines Verstehens des einzelnen historischen Dialoggeschehens nicht entgegen. Die Deutungsmuster ermöglichen gerade den Vergleich mit Gesprächssituationen in anderen zeitlichen und kulturellen Kontexten, der wiederum eine Voraus-

59 | CR 4, 1451-1452, Nr. 2287 (Schreiben der altgläubigen Stände an Kaiser Karl V.; [Regensburg], 1. Juli 1541): "Und in Summa mögen sich diese Stände nicht entschließen, noch bei ihnen befinden, daß dieses Buch einige Vergleichung, sondern vielmehr mehrere Uneinigkeit, Secten und Verlust gebären, einführen und wirken würde." Unzweideutig auch Eck, ebd., 459-460, Nr. 2291: "Neque placuit, neque placet liber iste insulsus, neque placebit, in quo tot errores et vitia deprehendi; unde iudico, sicut semper iudicavi, eum Catholicis non recipiendum, quia relicto modo loquendi ecclesiae et patrum Melanchthonizat." ["Dieses ungereimte Buch hat weder gefallen, noch gefällt es, noch wird es gefallen, in dem ich so viele Irrtümer und Fehler bemerkt habe; daher urteile ich, wie ich immer geurteilt habe, dass die Katholiken es nicht rezipieren sollen, weil es unter Preisgabe der Redeweise der Kirche und der Väter melanchthonisiert."] Vgl. dazu Lexutt (1996), 260-270. Zu Luther siehe WABr 9, 460, 1-7 (Luther und Bugenhagen an Kurfürst Johann Friedrich; [Wittenberg], 29. Juni 1541): "G[nade] V[nd] F[riede] in Christo! Durchleuchtigster Hochgeborner Furst, Gnedigster herr! Wie ich im anfang gesaget, vnd noch sage, die erfarung auch gibt, Das die vergleichung in der Religion fürgenomen ein lauter Mentzische [mainzische, M.N.] vnd papistische Teuscherey ist, Denn es ist vnmüglich Christum zuuergleichen mit der schlangen, vnd ist nichts drinn gesucht, denn vnser vnglimpff, on Das ichs gern gesehen, das vnser lehr nur wol disputirt, geleutert vnd erkandt wuerde, wie zu Augspurg geschehen." 
setzung ist, um die spezifischen Bedingungen des Scheiterns der innerchristlichen Religionsgespräche im 16. Jahrhundert erfassen zu können.

Es ist nicht zu übersehen, dass die Faktoren im Blick auf die Bedingungen des Scheiterns schwerlich von demselben Gewicht sind. Sie alle konnten zwar schon für sich allein genommen und erst recht im Verbund das Scheitern des Gesprächs herbeiführen. Divergente Zielvorstellungen und fehlende Kompromissbereitschaft jedoch waren Faktoren, die prinzipiell veränderbar waren und sich, wie gesehen, im Verlauf einer Begegnung auch ändern konnten. Sie bestimmten - nicht anders als der Faktor des verweigerten Mandats - die Religionsgespräche zudem keineswegs durchgängig. Anders sieht es dagegen mit den inhaltlichen Differenzen und den Befangenheiten in unterschiedlichen Wahrnehmungs- und Sprachmustern aus. Beide Faktoren wirkten bei nahezu allen Religionsgesprächen zusammen und waren gegenüber dem Verlauf der Begegnung vergleichsweise resistent. Nahmen die Kollokutoren in den für die eigene Überzeugungsgemeinschaft erheblichen Fragen des Glaubens gegensätzliche Standpunkte ein, und das dürfte bei nahezu allen Religionsgesprächen der Fall gewesen sein, war eine Einigung unter dem Vorzeichen eines streng einlinigen religiösen Wahrheitskonzeptes sowie der Dynamik sich ausbildender konfessioneller Identitäten praktisch unerreichbar, selbst wenn die Bereitschaft zum Kompromiss vorhanden war. Oft sahen gerade die nicht unmittelbar am Gespräch beteiligten Theologen aus der Distanz besser, worüber sich die Kollokutoren noch hinwegtäuschen konnten: Dass divergente, ja teilweise gegensätzliche, aber zugleich für das jeweilige konfessionelle Selbstverständnis essenzielle Lehransichten selten überzeugend synthetisch verbunden werden und wohl noch seltener einfach nebeneinanderstehen bleiben können. Ähnlich verhält es sich mit den Wahrnehmungs- und Sprachmustern, die sich innerhalb der einzelnen konfessionellen Gruppierungen schnell eigenständig entwickelten und die Verständigung mit anderen Gruppierungen erschwerten. Sie kamen den Kollokutoren meist nicht so zu Bewusstsein, dass sie angesprochen und Gegenstand eines »Vergleichs« hätten werden können. Wenn es sinnvoll ist, entsprechend der eingangs genannten Vermutung von strukturellen Faktoren zu sprechen, dann lassen sich somit am ehesten die inhaltlichen Differenzen sowie die Befangenheiten in den Wahrnehmungs- und Sprachmustern als »strukturelle Faktoren « begreifen, die selbst bei günstigen Bedingungen eine Verständigung letztlich verhinderten. 
Nicht wenige Initiatoren waren im Grund von der Erfolglosigkeit überzeugt, weshalb sie, wie gesehen, auch andere Ziele mit den Gesprächen verbanden. Ein Gespräch, das zu keinem belastbaren Ausgleich führte, konnte etwa als Demonstration der eigenen konfessionellen Position durchaus als Erfolg verbucht werden. Damit deutet sich bereits an, dass mit der Feststellung des Scheiterns hinsichtlich des religiösen »Vergleichs« allein schwerlich schon die historische Bedeutung dieser Gespräche zureichend erfasst werden kann. Abgesehen von der Tatsache, dass die Religionsgespräche zumindest in der Form der Reichsreligionsgespräche eine militärische Lösung der causa religionis zeitweilig verhindert haben, schärften sie zweifellos den Blick für das Trennende. Sie regten dazu an, die Differenzen präziser zu beschreiben oder den unterscheidenden Charakter bestehender Lehrformulierungen zu entdecken. Sie vermochten sich auf die einzelnen konfessionellen Gruppierungen geradezu identitätsstabilisierend auszuwirken. Dadurch haben sie prima facie das Gegenteil dessen erreicht, was die Initiatoren sich von diesen Gesprächen erhofften: Sie stärkten das Bewusstsein der Trennung und wurden zu einem bedeutsamen Movens im vielschichtigen Prozess der Konfessionalisierung, dem sie eigentlich entgegenwirken sollten. ${ }^{60} \mathrm{Zu}$ gleich haben die Gespräche aber allerdings auch, wenigstens in Ansätzen, den Blick für das Gemeinsame der sich konfessionalisierenden Kirchen eröffnet. Dass damals überhaupt der Versuch unternommen wurde, die verschiedenen Bekenntnishaltungen jenseits der gewohnten Kommunikationsform der Disputation und ihres zweiwertigen Wahrheitsverständnisses ins Gespräch zu bringen, dass damals überhaupt der Versuch eines Kolloquiums unternommen wurde, dürfte in seiner historischen Bedeutung nicht zu unterschätzen sein. In übergeordneter historischer Perspektive wirkten die Religionsgespräche des 16. Jahrhunderts mit ihrem Gestus des gegenseitigen Wahrnehmens wie ein Ritardando angesichts der heraufziehenden Konfessionskriege. Ihr Scheitern entbehrt - so gesehen - nicht einer gewissen Tragik.

60 | Diesen Aspekt betont zu Recht Dingel (1997), 670-671. 


\section{Bibliographie}

\section{Quellen}

\section{a. Drucke (16.-18. Jahrhundert)}

[Jacob Andreae]: Colloqvium Mompelgartense. Gespraech/Jn gegenwart des Durchleuchtigen [...] Herrn Friderichen/Grauen zu Wuertemberg vnd Muempelgart/etc. [...] Zwischen den Hochgelehrten/D. Iacobo Andreae, Propst vnd Cantzler der Hohen Schul zu Tuebingen/vnnd D. Theodoro Beza, Professorn vnd Pfarrern zu Genff. [...], Tübingen: Gruppenbach, Georg, 1587.

VD16 A 2488; Expl. BSB München, 4 H.ref. 174; urn: nbn:de:bvb:12bsb10160416-1

[Johannes Brenz]: Protocoll Das ist/Acta oder Handlungen des Gesprechs/ zwischen den Pfältzischen vnd Wirtembergischen Theologen/von der Vbiquitet oder Allenthalbenheit des Leibs Christi/vnd von dem buchstäbischen verstand der wort Christi/Das ist mein Leib/etc. Im April des Jars 1564. zu Maulbrun gehalten. [...], Heidelberg: Mayer, Johann aus Regensburg, 1565 .

VD16 B 7851; Expl. BSB München, 4 H.ref. 604; urn: nbn:de:bvb:12bsbio16o737-2

[Johannes Brenz]: Protocollum hoc est, Acta Colloqvii Inter Palatinos Et VVirtebergicos Theologos, de Vbiquitate siue omnipraesentia corporis Christi, Et de sensu verborum Christi, Hoc est corpus meum, \&c. Anno M. D. LXVIII [sic!]. Mulbrunnae habiti. [...], Heidelberg: [Schirat, Michael?] 1566.

VD16 B 7854; Expl. SB Berlin, Dk 2646; PPN746955626

Martin Bucer: Acta Colloqvii In Comitiis Imperii Ratisponae Habiti, Hoc Est Articvli de religione conciliati, \& non conciliati omnes ut ab Imperatore Ordinibus Imperij ad iudicandum, \& deliberandum propositi sunt. [...], Straßburg: Rihel, Wendelin d.Ä., 1541.

VD16 B 8831; Expl. BSB München, Res/4 H.ref. 136; urn: nbn:de:bvb:12bsbooo86468-8

Martin Bucer: Alle Handlungen vnd Schrifften/zů vergleichung der Religion/durch die Key[serliche]. Mai[estät]/Churfürsten/Fürsten/vnd Stände/aller theylen/Auch den Päbst [lichen] Legaten/auff jüngst gehaltnem Reichstag zů Regenspurg/verhandlet/vnd einbracht/Anno D.M.XLI. [...], Straßburg: Rihel, Wendelin d.Ä., 1542. 
VD16 B 8836; Expl. BSB München, 4 H.ref. 477, Beibd. 2; urn: nbn:de: bvb:12-bsbooo22538-9

[Martin Bucer]: Etliche gesprech ausz Göttlichem vnnd geschribnen Rechten vom Nürnbergischen fridestand/der streitigen Religion halb/ Anno etc. xxxij. Franckfortischen anstand/jüngst im Aprillen dises xxxix. jars auffgericht. Künftiger handlung gen Nürnberg angesehen/ den span der Religion hinzulegen [...], Augsburg: Steiner, Heinrich von Augsburg 1539.

VD16 B 8884; Expl. BSB München, 4 H.ref. 804,15; urn: nbn:de:bvb:12bsbooo18744-8

Martin Bucer: Vom tag zu Hagenaw vnd wer verhinderet hab/das kein gesprech von vergleichung der Religion daselbst fürgangen ist. [...], [Straßburg] [Prüß, Johann d.J.] 1540.

VD16 B 8937; Expl. BSB München, 4 Conc. 163, Beibd.1; urn: nbn:de:bvb:12-bsbooo18744-8

Christoph Erhard: Newer Euangelischer Catechismus. Das ist: Ein sehr nützliches/lustigs vnd kurtzweiliges Religionsgespräch/eines Catholischen Christen/vnd Evangelischen Lutheraners/in Form und Weise eines Catechismi. Sampt angehengtem Lutherischen Irrgarten [...], München: Berg, Adam, 1589.

VD16 E 3760; Expl. BSB München, P.lat. 2054, Beibd., 2; urn: nbn:de:bvb:12-bsbi1o12355-7

Christian Francke: Ein Gesprech Von Jesuitern Allen frommen Christen/ die Jesuiter vnd ihre Religion recht zu erkennen/Vast nützlich zulesen [...], Basel: Perna, Peter, 1581.

VD16 F 2185; Expl. BSB München, Polem. 1963, Beibd. 2; urn: nbn:de:bvb:12-bsb10194334-o

Philipp Melanchthon: Alle Handlungen die Religion belangend/so sich zu Worms/vnd Regensburg/auff gehaltenem Reichstag/des M.D.XLI. jars zugetragen/[...], Wittenberg: Lufft, Hans, 1542.

VD16 M 2388; Expl. BSB München, 4 H.ref. 410; urn: nbn:de:bvb:12bsbio160583-7

Protocoll. Das ist/Alle handlung des gesprechs zu Franckenthal inn der Churfürstlichen Pfaltz/mit denen so man Widertäuffer nennet/Auff den 28. May angefangen/vnd den 19. Junij dises 1571. jars geendet. [...], Heidelberg: Mayer, Johann aus Regensburg, 1571.

VD16 P 5105; Expl. BSB München, 4 H.ref. 6o1; urn: nbn:de:bvb:12-bsb $00060494-9$ 


\section{b. Drucke (19,-21. Jahrhundert)}

Baum, Wilhelm [u.a.] (Hg.) (1863-19oo): Ioannis Calvini: Opera quae supersunt omnia, 59 Bde., Braunschweig (= New York 1964) (CR).

Bretschneider, Karl Gottlieb [u.a.] (Hg.) (1834-186o): Philippi Melanthonis Opera quae supersunt omnia, 28 Bde., Halle an der Saale/Braunschweig (= Bad Feilnbach 1990) (CR).

Friedberg, Emil (Hg.) (1879/81): Corpus Iuris Canonici, 2 Bde., Leipzig (= Union City 2000).

Ganzer, Klaus (Hg.) (2000): Das Hagenauer Religionsgespräch, 2 Bde., Göttingen.

Ganzer, Klaus (Hg.) (2002): Das Wormser Religionsgespräch, 2 Bde., Göttingen.

Ganzer, Klaus (Hg.) (2007): Das Regensburger Religionsgespräch, 2 Bde., Göttingen.

D. Martin Luthers Werke. Kritische Gesamtausgabe, Briefwechsel, 18 Bde., Weimar 1930-1985 (WABr); Tischreden, 6 Bde., Weimar 1912-1921 (WATr).

Neuser, Wilhelm Heinrich (Hg.) (1974): Die Vorbereitung der Religionsgespräche von Worms und Regensburg 1540/41, Neukirchen-Vluyn.

von Kluckhohn, August (Hg.) (1868-1872): Briefe Friedrich des Frommen, Kurfürsten von der Pfalz, 2 Bde., Braunschweig.

von Tetleben, Valentin (1958): Protokoll des Augsburger Reichstags 1530, Göttingen.

\section{Literatur}

Augustijn, Cornelis (2001): »Melanchthons Editionen der Akten von Worms und Regensburg 1540 und 1541«, in: Loehr, Johanna (Hg.): Dona Melanchthoniana. Festgabe für Heinz Scheible zum 70. Geburtstag, Stuttgart-Bad Cannstatt, 25-39.

Bartel, Oskar (1973): »Der Consensus Sendomiriensis vom Jahre $1570 \mathrm{im}$ Lichte der ökumenischen Bestrebungen in Polen und Litauen im 16., 17. und 18. Jahrhundert«, in: Luther-Jahrbuch 40, 107-128.

Beumer, Johannes (1964): »Das Religionsgespräch und die ihm eigene Problematik«, in: Theologie und Glaube 54, 321-332.

Brand, Hans C. (2000): »Brenz' Christologie und ihre von Jakob Andreae vertretene Form. Das Maulbronner Kolloquium 1564«, in: Blätter für württembergische Kirchengeschichte 100, 58-84. 
Braunisch, Reinhard (1974): Die Theologie der Rechtfertigung im »Enchiridion « (1538) des Johannes Gropper, Münster.

Decot, Rolf (2007): »Reichstage und Religionsgespräche. Zur reichspolitischen Behandlung der Religionsfrage«, in: Brosseder, Johannes/ Wriedt, Markus (Hg.): »Kein Anlass zur Verwerfung«. Studien zur Hermeneutik des ökumenischen Gesprächs. Festschrift für Otto Hermann Pesch, Frankfurt a.M., 110-139.

Decot, Rolf (1989): Vermittlungsversuche auf dem Augsburger Reichstag 1530. Melanchthon, Brenz, Wiesbaden.

Deutsches Wörterbuch von Jakob und Wilhelm Grimm, Fotomechan. Nachdruck der Erstausgabe 1854-1971, 33 Bde., München 1999.

Dingel, Irene (1997): »Art. Religionsgespräche IV. Altgläubig - protestantisch und innerprotestantisch«, in: Theologische Realenzyklopädie 28, 654-681.

Dittrich, Franz (1892): Commentatio Miscellanea Ratisbonensia a. 1541 (Index lectionum in Lyceo Regio Hosiano Brunsbergensi), Braunsberg.

Dufour, Alain (1980): »Das Religionsgespräch von Poissy. Hoffnungen der Reformierten und der >Moyenneurs'«, in: Müller, Gerhard (Hg.): Die Religionsgespräche der Reformationszeit, Gütersloh, 117-126.

Fraenkel, Pierre (1965): Einigungsbestrebungen in der Reformationszeit, Wiesbaden.

Fuchs, Thomas (1995): Konfession und Gespräch. Typologie und Funktion der Religionsgespräche in der Reformationszeit, Köln [u.a.].

Ganzer, Klaus (2009): »Gasparo Contarini und Giovanni Morone. Das Regensburger Religionsgespräch von 1541 und das Werden einer Freundschaft«, in: Cristianesimo nella storia 30, 99-133.

Greulich, Gerhard (1959): Das Religionsgespräch mit den Täufern zu Frankenthal 1571, Diss. maschr., Heidelberg.

Güss, Ernst Friedrich Peter (1960): Die kurpfälzische Regierung und das Täufertum bis zum dreißigjährigen Krieg, Stuttgart.

Hege, Christian (1908): Die Täufer in der Kurpfalz. Ein Beitrag zur badischpfälzischen Reformationsgeschichte, Frankfurt a.M.

Hein, Lorenz (2001): »Das Zweite Helvetische Bekenntnis und der Sandomirer Konsens von 1570«, in: Schindler, Alfred/Stickelberger, Hans (Hg.), Die Züricher Reformation. Ausstrahlungen und Rückwirkungen. Wissenschaftliche Tagung zum hundertjährigen Bestehen des Zwinglivereins (29. Oktober bis 2. November 1997 in Zürich), Bern [u.a.], 425-431. 
Herbst, Wilhelm (1928): Das Regensburger Religionsgespräch von 1601 geschichtlich dargestellt und dogmengeschichtlich beleuchtet, Gütersloh.

Hering, Carl Wilhelm (1836/38): Geschichte der kirchlichen Unionsversuche seit der Reformation bis auf unsere Zeit, 2 Bde., Leipzig.

Hollerbach, Marion (1982): Das Religionsgespräch als Mittel der konfessionellen und politischen Auseinandersetzung im Deutschland des 16. Jahrhunderts, Frankfurt a.M. [u.a.].

Honée, Eugène (1993): »Die Religionsverhandlungen der Reichstage von Nürnberg (1524), Speyer (1526) und Augsburg (1530) und die Entstehung der Idee eines Religionsgesprächs«, in: Nederlands archief voor kerkgeschiedenis 73, 1-30.

Honée, Eugène (1985): »Über das Vorhaben und Scheitern eines Religionsgesprächs. Ein Verfahrensstreit auf dem Konvent von Hagenau (1540)«, in: Archiv für Reformationsgeschichte 76, 195-216.

Immenkötter, Herbert (1981): Der Reichstag zu Augsburg und die Confutatio. Historische Einführung und neuhochdeutsche Übertragung, 2. Aufl., Münster.

Immenkötter, Herbert (1973): Um die Einheit im Glauben. Die Unionsverhandlungen des Augsburger Reichstags im August und September 1530, Münster.

Immenkötter, Herbert/Wenz, Gunther (1997): Im Schatten der Confessio Augustana. Die Religionsverhandlungen des Augsburger Reichstages 1530 im historischen Kontext, Münster.

Janssen, Johannes (1897): Geschichte des deutschen Volkes seit dem Ausgang des Mittelalters, Bd. 2: Zustände des deutschen Volkes seit dem Beginn der politisch-kirchlichen Revolution bis zum Ausgang der socialen Revolution von 1525, 17. und 18., vermehrte und verbesserte Aufl., Freiburg i.Br.

Janssen, Johannes (1899): Geschichte des deutschen Volkes seit dem Ausgang des Mittelalters, Bd. 3: Allgemeine Zustände des deutschen Volkes seit dem Ausgang der sozialen Revolution bis zum sogenannten Augsburger Religionsfrieden von 1555, 17. und 18., vielfach vermehrte und verbesserte Aufl., Freiburg i.Br.

Janssen, Wibke (2009): »Wir sind zum wechselseitigen Gespräch geboren«. Philipp Melanchthon und die Reichsreligionsgespräche von 1540/41, Göttingen.

Jedin, Hubert (1958): »An welchen Gegensätzen sind die vortridentinischen Religionsgespräche zwischen Katholiken und Protestanten gescheitert?«, in: Theologie und Glaube 8, 50-55. 
Lane, Anthony N. (2004): »Cardinal Contarini and article 5 of the Regensburg Colloquy (1541)«, in: Ganoczy, Alexandre (Hg.): Grenzgänge der Theologie. Professor Alexandre Ganoczy zum 75. Geburtstag, Münster, 163-19o.

Leppin, Volker (2010): »Text, Kontext und Subtext. Eine Lektüre von Luthers Coburgbriefen«, in: Korsch, Dietrich/Leppin, Volker (Hg.): Martin Luther - Biographie und Theologie, Tübingen, 169-181.

Lexutt, Athina (1996): Rechtfertigung im Gespräch. Das Rechtfertigungsverständnis in den Religionsgesprächen von Hagenau, Worms und Regensburg 1540/41, Göttingen.

Lortz, Joseph (1982): Die Reformation in Deutschland, 6. Aufl., Freiburg i.Br. [u.a.].

Luttenberger, Albrecht Pius (1988): »Johann Eck und die Religionsgespräche«, in: Iserloh, Erwin (Hg.): Johannes Eck (1486-1543) im Streit der Jahrhunderte. Internationales Symposium der Gesellschaft zur Herausgabe des Corpus Catholicorum aus Anlaß des 500. Geburtstages des Johannes Eck vom 13. bis 16. November 1986 in Ingolstadt und Eichstätt, Münster, 192-222.

Luttenberger, Albrecht Pius (1988): »Konfessionelle Parteilichkeit und Reichspolitik. Zur Verhandlungsführung des Kaisers und der Stände in Regensburg 1541«, in: Angermeier, Heinz/Meuthen, Erich (Hg.): Fortschritte in der Geschichtswissenschaft durch Reichstagsaktenforschung. Vier Beiträge aus der Arbeit an den Reichstagsakten des 15. und 16. Jahrhunderts, Göttingen, 65-101.

Martens, Gottfried (1992): Die Rechtfertigung des Sünders - Rettungshandeln Gottes oder historisches Interpretament. Grundentscheidungen lutherischer Theologie und Kirche bei der Behandlung des Themas »Rechtfertigung«im ökumenischen Kontext, Göttingen.

Mieth, Dietmar (1990): »Vom Ethos des Scheiterns und des Wiederbeginns. Eine vergessene theologisch-ethische Perspektive«, in: Concilium 26, 385-393.

Moeller, Bernd (1970/1974): »Zwinglis Disputationen. Studien zu den Anfängen der Kirchenbildung und des Synodalwesens im Protestantismus«, 2 Teile, in: Zeitschrift der Savigny-Stiftung für Rechtsgeschichte. Kanonistische Abteilung 56, 275-324; 60, 213-364.

Moeller, Bernd (2011): Zwinglis Disputationen. Studien zur Kirchengründung in den Städten der frühen Reformation, 2. Aufl., Göttingen. 
Moser, Christian (2009): »Gespräch wider Willen. Der Konstanzer Disputationsversuch mit Zürich, 1597-1603«, in: Moser, Christian/Opitz, Peter (Hg.): Bewegung und Beharrung. Aspekte des reformierten Protestantismus, 1520-1650. Festschrift für Emidio Campi, Leiden [u.a.], 65-9o.

Müller, Gerhard (Hg.) (1980): Die Religionsgespräche der Reformationszeit, Gütersloh.

Münch, Paul (2004): »)Una disputa tenebitur inter Papistas et Lutheranos ...<. Ein Dunkelmännerbrief zum Regensburger Religionsgespräch 1601«, in: Engelbrecht, Jörg/Laux, Stephan (Hg.): Landes- und Reichsgeschichte. Festschrift für Hansgeorg Molitor zum 65. Geburtstag, Bielefeld, 97-116.

Nugent, Donald (1974): Ecumenism in the age of the Reformation. The Colloquy of Poissy, Cambridge (Mass.).

Olson, Jeannine E. (2009): »An English window on the Huguenot struggle for recognition. Nicolas Des Gallars and the colloquy of Poissy«, in: Toronto Journal of Theology 25, 227-238.

Ortmann, Volkmar (2010): »Ist nicht wunderbar der Sieg unseres Königs Jesus Christus? Calvin und die Religionsgespräche 1539-1541«, in: Jahrbuch der Hessischen Kirchengeschichtlichen Vereinigung, 35-54.

Ortmann, Volkmar (2001): Reformation und Einheit der Kirche. Martin Bucers Einigungsbemühungen bei den Religionsgesprächen in Leipzig, Hagenau, Worms und Regensburg, 1539-1541, Mainz.

Petkunas, Darius (2009): »The >Consensus of Sandomierz<. An early attempt to create a unified Protestant Church in 16th century Poland and Lithuania«, in: Concordia Theological Quarterly 73, 317-346.

Pfnür, Vinzenz (1980): »Die Einigung bei den Religionsgesprächen von Worms und Regensburg 1540/41 - eine Täuschung?, in: Müller, Gerhard (Hg.): Die Religionsgespräche der Reformationszeit, Gütersloh, 5588.

Pfnür, Vinzenz (1988): »Johannes Ecks Verständnis der Religionsgespräche, sein theologischer Beitrag in ihnen und seine Sicht der Konfessionsgegensätze«, in: Iserloh, Erwin (Hg.): Johannes Eck (1486-1543) im Streit der Jahrhunderte, Münster, 223-226.

Raitt, Jill (1993): The Colloquy of Montbéliard. Religion and Politics in the Sixteenth Century, New York [u.a.].

Reinhard, Wolfgang (1980): »Glaube, Geld, Diplomatie. Die Rahmenbedingungen des Religionsgesprächs von Poissy im Herbst $1561 \ll$, in: 
Müller, Gerhard (Hg.): Die Religionsgespräche der Reformationszeit, Gütersloh, 89-116.

Remy, Jochen (1994): »Die Reichsreligionsgespräche von Hagenau, Worms und Regensburg (1540/41) als Ausgangspunkt für die Kölner Reformation«, in: Monatshefte für evangelische Kirchengeschichte des Rheinlandes 43, 29-49.

Scheib, Otto (2009/10): Die innerchristlichen Religionsgespräche im Abendland. Regionale Verbreitung, institutionelle Gestalt, theologische Themen, kirchenpolitische Funktion. Mit besonderer Berücksichtigung des konfessionellen Zeitalters (1517-1689), 3 Bde, Wiesbaden.

Schmidt, Martin Anton (1973): »Das Frankenthaler Religionsgespräch 1571 und die Gegenwart. Ein vergessenes Jubiläum«, in: Zeitschrift für Religions- und Geistesgeschichte 25, 5-64.

Schornbaum, Karl (1905): »Zur Geschichte des Reichstages von Augsburg im Jahre 1530«, in: Zeitschrift für Kirchengeschichte 26, 142-149.

Schultheis, Saskia (2012): Die Verhandlungen über das Abendmahl und die übrigen Sakramente auf dem Religionsgespräch in Regensburg 1541, Göttingen.

Schwarz, Wilhelm (1886): »Eberhard Römische Beiträge zu Joh. Groppers Leben und Wirken«, in: Historisches Jahrbuch 7, 392-422.

Slenczka, Björn (2010): Das Wormser Schisma der Augsburger Konfessionsverwandten von 1557, Tübingen.

Spehr, Christopher (2010): Luther und das Konzil. Zur Entwicklung eines zentralen Themas in der Reformationszeit, Tübingen.

Steigelmann, Helmut (1970): Die Religionsgespräche zu Baden-Baden und Emmendingen 1589 und 1590, Karlsruhe.

Stolk, Johannes Maarten (2004): Johannes Calvijn en de godsdienstgesprekken tussen rooms-katholieken en protestanten in Hagenau, Worms en Regensburg. (1540-1541), Kampen.

Stupperich, Robert (1956): »Die Reformatoren und das Tridentinum«, in: Archiv für Reformationsgeschichte 47, 20-63.

Stupperich, Robert (1939): »Der Ursprung des >Regensburger Buches< von 1541 und seine Rechtfertigungslehre«, in: Archiv für Reformationsgeschichte 36, 88-116.

van Veen, Mirjam G. (2005): »Propaganda per brief. Calvijns brieven aan Farel over het godsdienstgesprek te Regensburg«, in: Theologisch debat $2,40-45$. 
Vogel, Lothar (2009): Das zweite Regensburger Religionsgespräch von 1546. Politik und Theologie zwischen Konsensdruck und Selbstbehauptung, Gütersloh.

von Bundschuh, Benno (1988): Das Wormser Religionsgespräch von 1557, Münster.

von Loewenich, Walther (1972): Duplex iustitia. Luthers Stellung zu einer Unionsformel des 16. Jahrhunderts, Wiesbaden.

Wartenberg, Günter (1980): »Die Leipziger Religionsgespräche von 1534 und 1539. Ihre Bedeutung für die sächsisch-albertinische Innenpolitik und für das Wirken Georgs von Karlowitz«, in: Müller, Gerhard (Hg.): Die Religionsgespräche der Reformationszeit, Gütersloh, 35-41.

Wrzecionko, Paul (1987): »Das ökumenische Programm der Union von Sandomierz, des Bartholomeus Bythner und des Daniel Kalaj«, in: Kirche im Osten 30, 26-41.

Wrzecionko, Paul (1980): »Die Religionsgespräche in Polen unter dem Aspekt ihrer Unionsbestrebungen«, in: Müller, Gerhard (Hg.): Die Religionsgespräche der Reformationszeit, Gütersloh, 145-152.

Ziegler, Walter (1992): »Religion und Politik im Umfeld des Regensburger Religionsgesprächs«, in: Barth, Hans-Martin [u.a.] (Hg.): Das Regensburger Religionsgespräch im Jahr 1541. Rückblick und aktuelle ökumenische Perspektiven, Regensburg, 9-30.

zur Mühlen, Karl-Heinz, (1969): »Calvins Urteil über den Rechtfertigungsartikel des Regensburger Buches«, in: Greschat, Martin/Goeters, Johann Friedrich Gerhard (Hg.): Reformation und Humanismus. Festschrift für Robert Stupperich, Witten, 176-194.

zur Mühlen, Karl-Heinz (1979): »Die Einigung über den Rechtfertigungsartikel auf dem Regensburger Religionsgespräch von 1541 - eine verpaßte Chance?«, in: Zeitschrift für Theologie und Kirche 76, 331-359.

zur Mühlen, Karl-Heinz (2005):«Die Reichsreligionsgespräche von Hagenau, Worms und Regensburg 1540/41. Chancen und Grenzen des kontroverstheologischen Dialogs in der Mitte des 16. Jahrhunderts «, in: Blätter für pfälzische Kirchengeschichte und religiöse Volkskunde 72 , 319-334. 



\title{
Substituting Fantasy for Achievement
}

\author{
Walter Ralegh's Failure as Discoverer and its Vindication
}

\author{
Frank Erik Pointner
}

SIR Walter Rawleigh was one, that (it seems) Fortune had pickt out of purpose, of whom to make an example, or to use as her Tennis-Ball, thereby to shew what she could doe; for she tost him up of nothing, and too and fro to greatnesse, and from thence down to little more than to that wherein she found him. ${ }^{1}$

This is the beginning of Robert Naunton's (1563-1635) account of the life of Sir Walter Ralegh included in his Fragmenta Regalia, which was published posthumously in 1641 . It pictures the life of one of the most flamboyant characters in Elizabethan England, whom the queen, here allegorized as Goddess Fortuna, tossed up like a tennis ball, which she let reach its highest point only to dart it to the ground. The full title of the work Fragmenta Regalia or Observations on the Late Queen Elizabeth, her Times and Favorites alludes to the most decisive principle shaping the social dynamics of Queen Elizabeth' reign (1558-1603): the allocation of power, honour and riches according to the queen's caprice. And Walter Ralegh was for a decisive span of his life Elizabeth's foremost favourite, probably only rivaled by the Earls of Leicester and Essex, respectively. Naunton's above allegory of Ralegh's meteoric rise, his apogee and his downfall, exemplifies the feeble position that courtiers held. Some of them might very well end up on the scaffold, of which the Earl of Essex presents the most prominent example. Others might 'only' be degraded, as was the case with Ralegh. The reasons for such like falls from grace ranged from alleged treason (Essex) to such trifles as having married without the Queen's consent (Leicester and Ralegh). This essay will concentrate on Ralegh's disgrace and its aftermath.

1 | Naunton (1641), 30. 
It will read his travelogue The Discoverie of the Large, Rich and Bewtiful Empyre of Guiana (1596) as his discursive attempt to turn defeat into victory, hoping to regain the Queen's favour and amend his failure as a courtier.

\section{The UpstaRt}

When the Earl of Oxford, one of the most public figures in Elizabethan England, called Walter Ralegh "the Jack, and upstart"2 he alluded to Ralegh's prominence within the queen's inner circle in spite of his comparatively humble upbringing. And indeed, although born to Walter Ralegh and Katherine Champernowne into the south western country gentry in 1552, "the younger Walter Ralegh derived no particular advantage from his descent. Though of respectable stock, he was the product of a third marriage and a second, the youngest of four sons to his father and five sons to his mother." It is easy to see that in an age when primogeniture was the foremost principle according to which titles, land and wealth were bequeathed to the next generation Ralegh must have cut a poor figure. His near contemporary Thomas Fuller puts explicit emphasis on this circumstance: “[Ralegh] was born ... of an Ancient Family, but decaied in Estate, and the youngest brother thereof." ${ }^{4}$ Here is an anecdote recorded by John Aubrey referring to Ralegh's destitution as a young Oxford student:

In his youth for severall yeares [...] he was under streights for want of money. I remember that Mr. Thomas Child of Worcestershire told me that Sir Walter borrowed a gowne of him when he was at Oxford (they were both of the same College), which he never restored, nor money for it. ${ }^{5}$

Ralegh, as a young student at Oxford, could not afford the obligatory gown. So he borrowed one which he neither returned nor paid for. But even if Ralegh had been first in line and had inherited his father's comparatively modest fortune, his birth right could not have been compared to that of his great competitors for the queen's favour, namely the Earls of Oxford,

2 | Ibid.

3 | Nicholls/Williams (2011), 7.

4 | Fuller (1662), 261.

5 | Aubrey (1949), 316. 
Essex and, above all, Leicester. Looking at it from that angle it is the more astounding that the country gentleman from the provinces, who, as Aubrey ensures us, retained his Devon brogue throughout his life ${ }^{6}$, rose to be the queen's favourite in the 1580 os accumulating honours and riches of an almost unprecedented scale. Here are only a few of the positions he held:7 Lord Warden of the Stannaries and High Steward of the Duchy of Cornwall, Lord Lieutenant of Cornwall and Vice-Admiral of the West, and, what is probably the peak of his career, Captain of the Guard, being in charge of the queen's protection in an age when possible assassins lurked around every corner. Ralegh was knighted on 6 January 1585 and in addition to the right to call himself Sir Walter from then on Elizabeth gave him lands and patents which turned him into one of the most affluent men of the realm. So what was it that attracted the queen to the young gentleman from the rural English West? Of course Ralegh had distinguished himself as an officer in Ireland having been instrumental to the suppression of an Irish rebellion in 1581 together with Lord Grey. ${ }^{8}$ But military success alone is not enough; it also has to be communicated to those in charge. And Ralegh seems to have excelled at exactly this point. Naunton suggests that his rhetorical skills were far superior to those of Grey and that consequently it was up to him to plead their case to the Queen and her Lords at the council table.

[Ralegh] had much better in the telling of his tale [...] for from thence he came to be known, and to have accesse to the Queen, and the Lords [...]. He had gotten the Queens eare at a trice, and she began to be taken with his elocution, and loved to hear his reasons to her demands. ${ }^{9}$

6 | “... notwithstanding his so great Mastership in Style and his conversation with the learnedest and politest persons, yet he spake broad Devonshire to his dying day." (Aubrey (1949), 318)

7 | Cf. Nicholls/Williams (2011), $26 \mathrm{ff.}$

8 | Cf. Nicholls/Williams (2011), $18 \mathrm{f}$.

9 | Naunton (1641), 31. Aubrey recounts the same tale: "He went into Ireland, where he served in the Warres, and shewed much courage and conduct, but he would be perpetually differing with (I thinke) Gray, then Lord Deputy, so that at last the Hearing was to be at council table before the Queen, which was what he desired; where he told his Tale so well, and with so good a Grace and Presence, 
Still, military success alone and the eloquent telling of it hardly explain the infatuation Elizabeth seems to have felt for the young man. Many other decorated war heroes did not achieve the intimacy that Ralegh and the Queen developed. Aubrey clearly suggests that Ralegh's physical appearance played its part:

[T] he Queen beheld him with admiration, as if a beautiful young Giant had stalked in with the service. ${ }^{10}$

Besides his outward handsome appearance, Naunton stresses Ralegh's natural poise and sophistication which retains all the properties of the Renaissance gentleman:

He had in the outward man, a good presence, in a handsome and well compacted person, a strong natural wit, and a better judgement, with a bold and plausible tongue, whereby he could set out his parts to the best advantage; and to these he had the adjuncts of some generall Learning, which by diligence he enforced to a great augmentation, and perfection; for he was an indefatigable Reader, whether by Sea or Land. ${ }^{11}$

In short, Ralegh was good looking, intelligent, rhetorically skilled, well read and erudite, and, what is more, he was able to use these proficiencies to his own advantage, namely to rise in the queen's esteem, benefitting from the "perks" that come with being one of her favourites. There is nothing to be added to Nicholls and Williams' shrewd analysis of the dynamics of courtly advancement under Queen Elizabeth:

It is, however, evident that a favourite's progress can assume a momentum of its own, once the fact of favour becomes apparent to others at Court. It is also clear that favour often follows a process of very careful political calculation. That was certainly the case with Ralegh. Access led to familiarity, familiarity led to an ob-

that the Queen tooke especiall notice of him, and presently preferred him." (Aubrey (1949), 316)

10 | Aubrey (1949), 317.

11 | Naunton (1641), 31. 
jective assessment of ability, and this assessment weighed the man's capacity to undertake particular or ceremonial tasks. ${ }^{12}$

However, this is only one side of the coin. What did Elizabeth expect in return? This is the question we have to tackle before we turn to Ralegh's eventual fall from grace and the strategies he employed to regain his blissful seat.

\section{THE LOVER}

The social dynamics at Queen Elizabeth's court were, of course, unique. There was this tension between the queen's two roles, between her being an absolute monarch and a woman in one person, a tension which best finds its expression in Elizabeth's famous 1588 address to her troops at Tilbury: "I know I have the body but of weak and feeble woman, but I have the heart and the stomach of a king."13 Even if the speech is apocryphal, it gives us some idea of how the discourse on the queen was structured. She possesses two bodies, a body natural and a body politic, and a courtier discursively had to come to terms with these two bodies at once. ${ }^{14} \mathrm{He}$ did so by employing two discourses ready at hand, as Frye explains:

[The discourses of Petrarchism and Neoplatonism] are of particular interest not only because Elizabeth used them, but also because courtiers used them in their attempts to penetrate her isolation, to address and persuade her. ... Petrarchism provided a ready means of expression for courtiers addressing a queen whose distance was quite real. ${ }^{15}$

Only in the discourse of Petrarchism, which is manifest in the hundreds of sonnets written during Elizabeth's reign, were traditional power-relations between the genders inverted. The sonnets and poems of similar

12 | Nicholls/Williams (2011), 23.

13 | Rice (1951), 96.

14 | Edmund Spenser in a letter to Ralegh directly draws on the two bodies of the queen: "For considering she beareth two persons, the one of a most royal queen or empress, the other of a most virtuous and beautiful lady." (Wills (1840), 294) 15 | Frye (1993), 108. 
form are invariably directed towards a chaste unattainable woman who is presented to be in every respect superior to her male suitor. This superiority is expressed in categories of space and time. The lady is not from this world, - and this is where Neoplatonism comes in - her origin is celestial, she is an angel who cannot be harmed by anything sublunar. And, what is more, age usually personified as Time, cannot harm her. Her life and even more importantly her beauty is eternal. Here are two stanzas from Ralegh's The Phoenix Nest (1593) directly addressed to Elizabeth herself.

In heuen Queene she is among the spheares,

In ay she Mistres like makes all things pure,

Eternitie in hir oft change she neares,

She beautie is, by hir the faire endure.

Time weares hir not, she doth his chariot guide,

Mortalitie belowe hir orbe is plaste,

By hir the virtue of the stars downe slide, In hir is vertues perfect image cast.

(Ralegh: Poems 11)

The lover delimitating himself from the distant ethereal creature stylises himself as her obedient humble servant whose entire well-being depends on her favour. However, the prerequisite for the Petrarchan discourse to be applicable is that the adored woman is a virgo immaculate in its true sense. ${ }^{16}$ And this is where Elizabeth's self-stylisation comes in. Not only did she put emphasis on her unmarried virginal state in many verbal utterances, her iconographic representations up to old age depict her with all the traditional attributes of the youthful immaculate virgin, as Frye's excellent reading of the rainbow portrait has shown. ${ }^{17}$ Those representations, verbal or iconographic, were mirrored by those they were addressed to, as Marotti explains:

In Elizabethan England, a female monarch, whose unmarried state preserved her symbolic and real value in both domestic and international transactions, espe-

16 | In Ralegh's The Phoenix Nest Elizabeth like in so many other poems is referred to as Diana, the goddess of chastity.

17 | Cf. Frye (1993), 107-109. 
cially encouraged the use of an amorous vocabulary by her courtiers to express ambition and its vicissitudes. ${ }^{18}$

Frye strikes the same note:

[T] he allegory of a youthful virgin represents Elizabeth's political vigor while allowing those who served her to continue expressing their desire for her favor as a desire for her person. ${ }^{19}$

Interestingly, this "desire" is not only expressed in poems, of which Ralegh's The Phoenix Nest is an adequate example. It is found in many other types of text. Here is a letter to Elizabeth by the Earl of Essex, which could just as well have been composed by Ralegh himself:

Most dear Lady, --My absence would be too unpleasant if I did not entertain myself with thinking of all those perfections which mine eyes enjoyed so lately to behold; and to make me mediate with more comfort, I will never cease to importune your Majesty, that I may, by some handwriting from your sacred self, be assured that I do not decrease in your Majesty's favour. I care for no cross of fortune, so long as I find your Majesty careth for me; neither can anything make me happy when I do not hold a first place in your favour. If any man will venture his life to persuade your Majesty of his faith, I will lose mine to prove your constancy. I wish your Majesty to be the greatest and happiest Prince, the kindest and constantest Mistress that ever was; and I will be ever your Majesty's most humble, affectionate, and devoted servant,

Dover, 16th October R. Essex ${ }^{20}$

This letter abounds with the topoi of Petrarchist poetry. Elizabeth is perfection personified, she is, to put it in neo-platonist terms, the eternal form of which all other women are imperfect copies. She is sacred, being the angelic figure that so many sonnet writers address in encomiastic terms and in whom they have absolute faith. The author's entire well-being depends on her favour, and nothing can happen to him as long as he is assured of his addressee's good will. At the same time the appellation as "constantest

18 | Marotti (1982), 398.

19 | Frye (1993), 101.

20 | Devereux (1853), 246. 
Mistress" has clear sexual implications, referring to the chastity of the monarch. And although the end formula of the "most humble, affectionate, and devoted servant" is ultimately indebted to Horatian modesty topoi so popular in Renaissance times, we may take them as direct expressions of the courtier's inferior state, a state which does not leave any room for direct supplication being entirely dependent on the Lady's caprice. Here is the couplet of Sonnet 61 of Edmund Spenser's Amoretti, which illustrates the tension between the quasi amorous relationship on the one and the hierarchical distance on the other hand, so constitutive of the Petrarchan mode:

Such heavenly forms ought rather worshipped be,

Than dare be loved by men of mean degree. ${ }^{21}$

The lady's/queen's heavenly neo-platonic form leaves only room for religious veneration. Earthly love is too base a feeling to be entertained for such a celestial being by a sublunar creature such as the male lover.

To sum it up, Petrarchism provides the blueprint for the discourse an Elizabethan courtier had to appropriate in his dealings with the queen. The use of Petrarchan formula stresses Elizabeth's femininity, thus sexualizing her. Most of all, the constant emphasis on her virginal state, i.e. the emphasis on the queen's refraining from sexual intercourse, constructs her ex negativo as a sexual being, whose body the courtier desires without being able to take possession of it. The queen herself encouraged the use of the Petrarchist discourse with regard to her person, thus exploiting "the gender-specific virtue she has so long and so successfully employed as a means of self-empowerment."22

21 | Spenser (1993), 611.

22 | Montrose (1993), 184. 


\section{The Disgraced}

Petrarchism provides the discursive environment we have to picture Walter Ralegh in in the 1580 s; an environment in which he stylizes himself as the Petrarchan lover of an unattainable mistress who, at the same time, requisitions such veneration. However, as far as the particular relationship between Ralegh and Elizabeth is concerned I would like to go one step further than seeing the Petrarchan discourse as merely symbolic, surmising that the queen's feelings for Ralegh were more than just role playing. Maybe this would explain her harsh reaction to Ralegh's betrayal of trust.

In November 1591 Ralegh secretly married the pregnant Elizabeth Throkmorton, one of the queen's Ladies in Waiting. ${ }^{23}$ When in August 1592 Elizabeth found out about the betrayal of her two favourites who had formed a matrimonial alliance without her consent she delivered them both to the Tower. ${ }^{24}$ Although they were released in the course of a year Ralegh was never forgiven and 1592 marks the turning point of his fortune. Of course it was to be expected that the queen would not be pleased with his stealthy marriage; the Raleghs seem to have been aware of this fact or they would not have tried to keep it a secret for that long. But compared with her reactions to similar offences of others the queen's attitude towards Ralegh seems out of place. As Nicholls and Williams recount:

Marriage control by the materfamilias counted for a great deal at the Elizabethan court. Leicester, after his marriage to Lettice Knollys in 1578, and Essex, following his marriage to Frances Sidney in 1590, had both flirted with the Tower. Both had enraged the Queen and both had been forgiven. ${ }^{25}$

We may only speculate about the reasons for Elizabeth's harsh treatment of Ralegh if compared to that of her other courtiers who committed the same "offence". Of course Nicholls and Williams' reasoning that "Leicester, Oxford and Essex enjoyed an independent status that helped them

23 | Fuller (1993), 233 refers to a lecture by Arthur Marotti in which he noted "the politicization of sexual activity at the court, and the displacement of male sexual advances onto the maids of honor who surrounded the queen".

24 | Cf. Nicholls/Williams (2011), 79.

25 | Ibid. 
to recover from misfortunes at Court"26 easier than Ralegh is sound and stresses once again that Ralegh's position as a "Jack, and upstart", which was much more precarious than that of titled members of the old aristocracy. At the same time, however, it is difficult to imagine that the Petrarchan role playing that Elizabeth and Ralegh had been involved in did not have any repercussion on real life. The following anecdote, recorded by Thomas Fuller in 1662 hints at the fact that verbal self-stylization may very well have been embedded in real life even including repartees with the Queen.

[C]oming to Court, [Ralegh] found some hopes of the Queens favour reflecting upon him. This made him write in a glasse Window obvious to the Queens eye,

Fain would I climb, yet fear I to fall,

Her Majesty either espying, or being shown it, did under-write,

If thy heart fails thee, climb not at all. ${ }^{27}$

The ratiocination that the Queen had some tender feeling for Ralegh, that there was a certain degree of life is copying art involved on her side - what Greenblatt calls "the interplay of life and art"28 - would explain why Ralegh's clandestine marriage with Elizabeth Throkmorton was never forgiven, and why Ralegh's numerous attempts to regain the queen's favour were largely unsuccessful. ${ }^{29}$ These attempts were first of all verbal. When incarcerated in the Tower of London, he wrote a letter to Robert Cecil to give vent to his dejection. Of course the implied addressee of the letter is the queen.

26 | Nicholls/Williams (2011), 86.

27 | Fuller (1662), 161.

28 | Greenblatt (1973), 99.

29 | Montrose at least grants that the possibility that jealousy may be one factor in the queen's dismissal of Ralegh: "Perhaps it cannot be decided, finally, whether to attribute the queen's anger toward Ralegh ... to the sexual jealousy of a mistress, betrayed by her lover." (Montrose (1993), 185) 
I, that was wont to behold her riding like Alexander, hunting like Diana, walking like Venus, the gentle wind blowing her fair hair about her pure cheeks, like a nymph, sometime sitting in the shade like a goddess, sometime singing like an angel, sometime playing like Orpheus; behold the sorrow of this world! once amiss hath bereaved me of all. ${ }^{30}$

All the images Ralegh employs play on the queen's chastity and her celestial being. But such supplications struck no note with Elizabeth anymore. Apparently the old Petrarchan and neo-platonic images, so successful during the time of theatrical courtship, had lost their effect and it would have been surprising if they had not. It is widely assumed that one reason for Elizabeth's constant refusal to get married was that it would deprive her of one of her most important means to exercise power over her courtiers, i.e. her being in charge of the discourse of male submission. A married woman would not have qualified anymore for a Petrarchan lady, and, consequently, the Petrarchan discourse her minions so grovellingly adhered to would be absurd. However, we may assume that similar dynamics were at play as far as the active role of the courtier was concerned. Ralegh, the married man, did not qualify anymore for an imaginative lover. The mellifluous and honey-tongued "suitor" had lost his right to express his reverence in the language of love. But where words fail there is only one possible option: words must give way to action. And this for an Elizabethan noble man could only mean war or exploration. Ralegh opted for the latter, "[t]o seek new worlds, for golde, for prayse, for glory" ${ }^{31}$ as he himself expressed it in his long elegiac poem "Ocean to Scinthia” (1. 61).

\section{The Derided}

On February 6, 1595 Ralegh with a small fleet departed for Guiana with two objectives in mind: the one being "the return of profit to ourselues", i.e. the discovery of large amounts of gold, the other being to prevent "trades of the Spanish nation". ${ }^{32}$ Of course both objectives are mutually dependent. There is no doubt that this enterprise materialized as a reac-

30 | www.bartleby.com/209/202.html.

31 | Ralegh: Poems 27.

32 | Ralegh (1596), 15 
tion to Ralegh's failure to regain his former position within the queen's inner circle. As Greenblatt argues:

The Guiana voyage was indeed a theatrical gesture calculated to dazzle the queen and win a return of her favour, but it was also the fulfillment of a personal vision. ${ }^{33}$

And Ralegh failed. When he came home there was neither gold, nor praise nor glory. The voyage proved a disaster on all of these accounts. Not only did he lose a considerable number of men in the unavoidable skirmishes with the Spanish, he neither could keep his promise to find the legendary city of Manoa ruled by the gold-dust-sprinkled King El Dorado, nor could he locate any easily accessible gold mines. ${ }^{34}$ Consequently, he did not bring home any amount of gold worth mentioning and found himself the object of public ridicule so that, if anything, the voyage was counterproductive in his endeavor to rekindle the Queen's interest in his person. Greenblatt sums up the contemporary reactions to Ralegh's enterprise most concisely:

[U]pon his return, [the queen] shared with the court, the powerful merchants of the City, and the general public a wry skepticism about his enthusiastic reports. Ralegh's enemies spread rumors that he had not been to Guiana at all, but had hidden in Devon or Cornwall until his ships came home again. Others whispered that, failing to discover any gold in Guiana, he had purchased the specimen ore he brought back on the Barbary Coast. In response to the doubts and the rumors, in an attempt to vindicate himself, Ralegh turned, as he had in the past, to writing. ${ }^{35}$

33 | Greenblatt (1973), 104. In his dedicatory epistle to Lord Howard and Robert Cecil prefixed to his Discovery of Guiana Ralegh points out that "[his] errors were great", and that the journey was meant to fix those. He hoped that he "might recouer ... the least tast of the greatest plenty formerly possessed" and to "appease so powrefull a displeasure". (Ralegh (1596), 5)

34 | For detailed accounts of Ralegh's search for gold and his failure cf. Lorimer (1982) and Lorimer (2007).

35 | Greenblatt (1973), 104. 
Thus we may read Ralegh's 1596 The Discovery of the Large, and Beautiful Empire of Guiana ${ }^{36}$ as his attempt to vindicate himself of these charges, which he directly comments upon in the address to the reader the Discovery is prefaced with. ${ }^{37}$ The travelogue is meant to prove that its author really was in Guiana. It is meant to prove that Guiana abounds in gold, although he has failed to bring home any amount of precious metal worth mentioning. It is meant to excite the queen's interest to invest in further expeditions to South America spearheaded by Ralegh himself. It is meant to justify the fact that in monetary and military terms the voyage was a complete failure. Above all, it is meant to rekindle the queen's fervor for her former favourite who is "contented to lose her highness fauour and good opinion foreuer" if the Guiana business will not prove a complete success in times to come, i.e. if reality will not stand up to "whatsoever is in this discourse promised or declared"38. Consequently, the remainder of this essay will not be concerned with what really happened in Guiana. Instead we will turn to Ralegh's discursive treatment of his failure in the Discovery.

\section{The Defender}

The first rumor Ralegh had to eliminate was that he had never been to Guiana but had hidden for the time his fleet was abroad in Cornwell or Devon. In order to do this he reverted to the obvious. The Discovery abounds in topographical and anthropological detail that only someone who was really there can have knowledge of. The full title of the travelogue already suggests that its author is an expert on his subject: The Discoverie of the Large, and Bewtifvl Empyre of Gviana, with a relation of the great and

36 | Ralegh's Discovery of Guiana exists in a manuscript and a print version which considerably differ. Joyce Lorimer has done a magnificent job in publishing both versions synoptically in 2006. Particularly her extensive Introduction to the beautiful volume is a treasure trove I am much indebted to. In this essay, however, I will exclusively rely on the version Ralegh published, since we may be sure that this is the one meant to vindicate his apparent failure and, consequently, the one we should turn to analyzing his discursive strategies.

37 | Ralegh (1596), 12-14.

38 | Ralegh (1596), 16. 
Golden Citie of Manoa (which the Spanyards call El Dorado) And of the Prouinces of Emeria, Arromaia, and other Countries, with their riuers, adiyning. ${ }^{39}$ The country is beautiful, it contains provinces which the author refers to by their indigenous names, and in spite of all rumors to the contrary El Dorado exists. Here is a randomly chosen passage abounding with detail that only the observant visitor can have knowledge of:

This Iland is called by the people therof Cairi, and in it are diuers nations: those about Parico are called laio, those at Punto Carao are of the Arwacas, and betweene Carao and Curiapan they are called Saluaios, betweene Carao and punto Calera are the Nepoios, and those about the Spanish Citie tearme themselues Carinepagotos. ${ }^{40}$

Not only do passages such as these reveal the author's intimate knowledge of the land, its peoples and the places they inhabit. Indigenous denominations, although sometimes mediated through Spanish, strengthen the local colour. Personal names of Indian chiefs, being called for instance “Wannawanare, Caroaori, Maquarima, Tarroopanama \& Aterima"41 bear no exception. Greenblatt's analysis certainly holds true:

These strange words do more than heighten the authenticity of the account. With their unfamiliar sounds and cadences they stimulate the reader's imagination, suggesting rich and strange and grandiose. ${ }^{42}$

Even Elizabeth's name is translated into the indigenous language. According to Ralegh, who has circulated the Queen's picture among the Indians, they call her "Ezrabeta Cassipuna Aquerewana, which is as much as Elizabeth, the great princesse or greatest commaunder." ${ }^{43}$

But the use of Spanish and indigenous languages is only the most obvious means Ralegh employs in order to suggest authenticity of his experience. In addition, there are detailed accounts of English raids on Spanish settlements, of negotiations with Indian chiefs, and, what may be most

39 | Ralegh (1596), 1.

40 | Ralegh (1596), 23

41 | Ralegh (1596), 29.

42 | Greenblatt (1973), 107.

43 | Ralegh (1596), 31. 
strange for us today, descriptions of creatures and people having their origin in the mists of myth and legend modern man has long discredited as being mere figments of the imagination. Here is Ralegh's report concerning the "warlike women", commonly known as Amazones. ${ }^{44}$

It was farther told me, that if in the wars they tooke any prisoners that they vsed to accompany with those also at what time soeuer, but in the end for certain they put them to death: for they are said to be very cruell and bloodthirsty, especially to such as offer to inuade their territories. ${ }^{45}$

This is exactly what his readers would expect. In pre-industrial times when even those that lived a few hundred miles away were surely perceived as being very strange indeed, people that lived virtually on the other side of the world were imagined to be entirely alien races. No doubt the widespread legends about cannibals, also mentioned by Ralegh ${ }^{46}$, were due to a large extent to this kind of reasoning. The "other" has to make you shudder. Thus, paradoxically, the most alien the tribes were that seafarers allegedly encountered, the more authentic their reports appeared to be. This may be the reason why Ralegh devoted a long passage to the tribe of the Ewaipanoma of which this is the beginning:

[The Ewaipanoma] are reported to haue their eyes in their shoulders, and their mouths in the middle of their breasts, \& that a long train of haire groweth backward betwen their shoulders. ${ }^{47}$

We may smile today that reports about headless men were given any credibility. However, we should not forget that many of Swift's contemporaries more than a century after Ralegh believed the stories about mean little dwarfs no bigger than a hand, giants as high as houses, speaking

44 | Of course most contemporary scholars would connect tales about Amazons with the ancient world. Lorimer enlightens us on this misconception: "The transplantation of Amazons to the New World occurred as early as Columbus's first voyage to the New World, and was firmly established by Orellana's alleged sighting of them on the 'rio de las Amazones' in 1540." (Lorimer (2006), ixxiii)

45 | Ralegh (1596), 65.

46 | Cf. Ralegh (1596), 159.

47 | Ralegh (1596), 157. 
horses and flying islands. Desdemona falls in love with Othello because of his stories about cannibals and creatures like Ralegh's Ewaipanoma, "[t]he Anthropophagi, and men whose heads/Do grow beneath their shoulders". ${ }^{48}$ She must have believed such accounts to be true. But what about Ralegh? He neither encountered the "cruell and bloodthirsty" women nor the headless men personally, but in order to lend veracity to his report he reverts to the strategy that the whole Discovery abounds in. As far as the Amazons are concerned, he owes his strange intelligence to "the most ancient and best traueled of the Orenoqueponi" ${ }^{49}$, thus relying on the best authority there can be, the indigenous people who told him about their exotic land face to face. Even more authorities are required to corroborate the existence of the Ewaipanoma. Rallegh's informants include "the son of Topiawari", who averted that he had seen them with his own eyes, "Maundeuile" whose many reports were once frowned upon, but are now proved to be true, and "a spanyard dwelling not farre from thence ... who being esteemed a most honest man of his word ... told me that he had seen manie of them". ${ }^{50}$

The substitution of personal experience which Ralegh did not make himself by reports of people who have made these experiences is the foremost strategy he employed in the Discovery to draw attention away from his own failure. And this is particularly the case as far as his greatest failure is concerned, his not having discovered the great city of Manoa and, consequently, his not having brought home any amount of gold worth mentioning. Reports by people he has encountered, Spanish and indigenous, leave no doubt that Manoa exists, and that Guiana is rich in gold. All the Queen has to do in order to become the richest and most powerful empress in the world is to reinstate him and finance subsequent expeditions no doubt led by Ralegh himself. The following passage is representative of his constructing his own credibility.

And as I haue beene assured by such Spanyardes as have seene Manoa the emperiall Citie of Guiana, which the Spanyardes cal el Dorado, that for the greatnes,

48 | Shakespeare, Othello 1.3.,145-146.

49 | Ralegh (1596), 63.

50 | Ralegh (1596), 159. 
for the riches, and for the excellent seate, it farre exceedeth any of the world as is knowen to the Spanish nation. ${ }^{51}$

There are Spaniards, Ralegh claims to have encountered, who have seen Manoa with their own eyes. However, Lorimer, comparing the above print version with the corresponding manuscript comes to the conclusion that Ralegh twists the truth. With regard to the claim that his informants have "seene" the golden city she comments: "An uncorrected exaggeration which crept into the rewritten portion of the text. None of Ralegh's Spanish informants mentioned elsewhere in the text claimed to have seen Manoa themselves" 52 . This "exaggeration" is most certainly a device consciously employed to raise his credibility. With regard to Ralegh's endeavour to authenticate his narrative by relying on Spanish informants Montrose uncovers a subversive irony:

This epistemological and ideological destabilization arises from Ralegh's repeated need to ground his own credibility upon the credibility of the very people whom he wishes to discredit. ${ }^{53}$

Still, the most extensive account of Manoa is by Juan Martinez "who was the first that discouered Manoa" (43). But of course Ralegh has not encountered this man himself, but knows about him from his written report. However Martinez did not write the report himself, but "deliuered ... the relation of his trauels" on his death bed to a friar. But even this report Ralegh has not seen himself, but knows about it from the Spanish commander in chief Bereo, who allegedly possessed a copy of it. ${ }^{54}$ Martinez is said to have lived seven months in Manoa, so we should assume that he would have been able to reveal its precise location. However, Ralegh

51 | Ralegh (1596), 37.

52 | Ralegh (1596), 37, fn 3.

53 | Montrose (1993), 192.

54 | Similarly, Ralegh recounts the common myth that "certain seruants of the Emperor hauing prepared golde made into fine powder blow it thorow hollow canes upon their naked bodies, vntill they be al shining from foote to the head" (Ralegh (1596), 51). Robert Dudley, certainly one of the most eminent men in Elizabethan England, owes this story to a letter written to Spain which was intercepted. Needless to say that Dudley is not in possession of this letter. 
ensures us that he could not for "hee was also brought thither all the waie blindfield, led by the Inidians" (47). This chain of events becomes even more abstruse when we learn that although this Martinez was released by the Indians after half a year and sent back with a lot of gold that the "borderers which are called Orenoqueponi robbed him and his Guianians of all the treasure" (47). Sometimes the concatenation of accidents is too unfortunate, most of all Martinez' ultimate fate which Ralegh succinctly sums up as "remaining a long tyme for passage into Spayne he died" (49), so that he could not be personally consulted anymore.

To sum it up, the El Dorado myth is due to the ravings of a dying man, whose narrations of his abode in Manoa were written down by his confessor of which one of Ralegh's captives allegedly possessed a copy which Ralegh has never seen. How desperate in his attempt to authenticate his claim that Manoa existed must Ralegh have been. He even goes as far as to quote written Spanish reports concerning the richess of the Emperor of Guiana in the original Spanish, which he afterwards translates. Of course, the use of the original language is meant to lend further authenticity to his report. ${ }^{55}$ Interestingly, Ralegh seems to be aware of the fact that statements like "the vessels of his house, table, and kitchin were of Gold and Siluer ... may seem straunge", yet he finds proof of these reports in the fact that the "Spanish King vexeth all the Princes of Europe" as far as his wealth is concerned. ${ }^{56}$

\section{The Humanitarian}

Another strategy Ralegh employs in order to prove the usefulness of the Guianian enterprise is ostensibly humanitarian. The indigenous people whose pristine innocence he never fails to point out ${ }^{57}$ are tormented by their Spanish oppressors, and it is the duty of every god-fearing English protestants to set an end to this regime of rape and torture.

55 | Ralegh (1596), 39.

56 | Ralegh (1596), 41.

$\mathbf{5 7}$ | Even when a Cassiqui is burried with a golden treasure, Ralegh, respecting their religion, does not open the grave (cf. Ralegh (1596), 203). 
... euery night there came some with most lamentable complaints of [Bereo's] cruelty, how he had deuided the lland \& giuen to euery soldier a part, that he made the ancient Casiqui which were Lordes of the country to be their slaues, that he kept them in chains, \& dropped their naked bodies with burning bacon, \& such other toments, which I found afterwards to be true. ${ }^{58}$

There are other reports about the slave trade in the course of which "the Spaniards make great profit". They buy young girls and sell them to the West Indies for twice the amount of money they paid for them. ${ }^{59}$ But worst of all is the Spanish propensity to ravish indigenous women.

... the Spaniards, who indeed (as they confessed) tooke from them their wiues, and daughters daily, and vsed them for the satisfying of their owne lusts. ${ }^{60}$

Of course alleged sexual transgressions have always been prominent in the catalogue of deviances enumerated in order to disparage enemies. However, as far as Ralegh's account is concerned, we should keep in mind whom the text is meant to impress: the queen, who in spite of her body politic is still a "weak and feeble woman". Consequently, Ralegh does not tire to point out English blamelessness as far as the treatment of indigenous women is concerned. None of his men "euer knew any of their women", although opportunity was not lacking, having encountered "very young [women], and excellently faured which came among vs without deceit, starke naked." ${ }^{61}$ The conclusion to be drawn from this list of Spanish cruelty ranging from torture and slavery to sexual transgression can only be that it is the moral duty of the English to free the poor Indians from the Spanish yoke. Thus Ralegh points out to Indian chiefs "that the Queenes pleasure was, I should vndertake the voyage for their defence, and to deliuer them from the tyrannie of the Spaniards." ${ }^{62} \mathrm{He}$ is only the Queen's instrument, like a good Petrarchan lover entirely depending on her "pleasure”. And his self-stylisation as the obedient humble servant of a celestial

\footnotetext{
58 | Ralegh (1596), 29.

59 | Ralegh (1596), 85.

60 | Ralegh (1596), 119.

61 | Ralegh (1596), 121.

62 | Ralegh (1596), 141.
} 
beauty is omnipresent in the Discovery. Here is a passage from the very beginning:

I made [the Indians] vnderstand that I was the seruant of a Queene, who was the great Casique of the north, and a virgin, and had more Casiqui vnder her then there were trees in their lland: that she was an enemy to the Castellani in respect of their tyrannie and oppression, and that she deliuered all such nations about her, as were by them oppressed. ... I shewed them her maiesties picture which they so admired and honored, as it had beene easie to haue brought them Idolatrous thereof. ${ }^{63}$

The characterization of the queen as an enemy of the Spanish and a most powerful ruler who will deliver everyone from their tyranny is most straight forward and refers to Elizabeth's body politic. But the fact that Ralegh stresses her virginity appears to be somewhat out of line today, as does the emphasis on her beauty, manifesting itself in "her maiesties picture". However, if we consider the queen's body natural, which is that of a woman adored in Petrarchist fashion, these two royal properties, virginity and beauty, have a clear function. Even the Indians idolize the beautiful virgin queen as an Elizabethan courtier would, or, to put it bluntly, they become perfect subjects, adoring the goddess of the north in an idolatrous fashion. Thus the queen's political body wields military power, while her gendered body is subject to adoration. And Ralegh's gendering does not stop here.

\section{The Conqueror}

In one of the most prominent passages of the Discovery even the land itself becomes the queen's virgin alter ego.

To conclude, Guiana is a Countrey that hath yet her Maydenhead, neuer sackt, turned, nor wrought, the face of the earth hath not beene torne, nor the virtue and salt of the soyle spent by manuarance, the graues haue not been opened for gold, the mines not broken with sledges, nor their Images puld down out of their

63 | Ralegh (1596), 31. 
temples. It hath neuer been entred by any armie of strength, and neuer conquered or possessed by any Christian Prince. ${ }^{64}$

Every image of this passage applies to a virgin, a woman, to put it bluntly, that has not been penetrated. ${ }^{65}$ The virgin land has not been torn, the graves have not been opened and the mines have not been broken. The land has never been entered, conquered or possessed. ${ }^{66}$ That there is a direct link between the land and the queen's matrimonial state becomes even more obvious in the remark about Guiana never having been "conquered or possessed by any Christian Prince". No western potentate has ever conquered the prelapsarian elysium, and no prince has ever succeeded in marrying, i.e. sexually subjugating, Elizabeth in spite of the august number of suitors, among them Prince Philip of Spain, Prince Frederick of Denmark, King Charles of France and the Archduke Charles of Austria. We may also assume that the parallelism between the South American country and Elizabeth works so well because the name Guiana itself sounds like a female Christian name and may therefore be much easier personified than other denominations.

However, there is one description of the land of Guiana to which this statement is even better applied.

I neuer saw a more beawtifull country, nor more liuely prospectes, hils so raised here and there ouer the vallies, the riuer winding into diuers braunches, the plaines adioyning without bush or stubble, all faire greene grasse, the ground of hard sand easy to march one, eyther for horse or foote, the deare crossing in euery path, the brids towards the euening singing on euery tree with a thousand seueral tunes,

64 | Ralegh (1596), 211.

65 | Ralegh's companion Lawrence Keymis in his 1596 A Relation of the Second Voyage to Guiana (for Keymis it was the second journey) is even more straight-forward in sexualizing the land by turning from metaphor to simile: "... whereas here whole shires of fruitful grounds, lying now waste for want of people, do prostitute themselves onto us, like a faire and beautifull woman, in the pride and floure of desired yeeres." (quoted from Montrose (1993),194)

66 In addition to these metaphors connoting the absence of any process of deflowering, many of the images belong to the stock inventory of Shakespearean sexual puns. May be it is not too far-fetched to invoke Hamlet's "country matters", or the frequent use of "possess" in Shakespearean sexual context. 
cranes \& herons of white, crimson, and carnation pearching on the riuers side, the ayre fresh with a gentle easterlie wind, and euery stone that we stooped to take up, promised eyther gold or siluer by his complexion. ${ }^{67}$

This passage is most ideal to show "the affinity between the discovery and the blazon". ${ }^{68}$ The land is particularized like a woman in the traditional descriptiones pulchritudinis as the sum of its parts. But this correspondence is not only in form but also in content. Every Elizabethan with some smattering of contemporary literature would have directly related these images to those metaphorically applied to the female body: hills and valleys, winding rivers, plains without bush or stubble, fair green grass etc. Maybe it is best to let literature speak for itself. When the female protagonist of Shakespeare's Venus and Adonis tries sexually to arouse her youthful lover she uses the same images Ralegh does to describe her naked perfect body:

'Fondling,' she saith, 'since I have hemm'd thee here

Within the circuit of this ivory pale,

I'll be a park, and thou shalt be my deer;

Feed where thou wilt, on mountain or in dale:

Graze on my lips; and if those hills be dry,

Stray lower, where the pleasant fountains lie.

Within this limit is relief enough,

Sweet bottom-grass and high delightful plain,

Round rising hillocks, brakes obscure and rough,

To shelter thee from tempest and from rain

Then be my deer, since I am such a park;

No dog shall rouse thee, though a thousand bark.'

The parallel diction between Ralegh's description of the elysian land of Guiana and Venus' description of her own sexualized body should be enough to establish the sexualization of the South American land. But what function does it have in Ralegh's ultimate endeavour to amend his failure and to be reinstated in the queen's favour? On a purely discursive level the Petrarchan sexualization of the Queen has, as we have seen,

67 | Ralegh (1596), 151-152.

68 | Montrose (1993), 189. 
failed to strike a note with Elizabeth after his marriage. Thus he diverts the discourse to another subject, the immaculate land of Guiana, whose pristine state is so much like the queen that the land virtually becomes her alter ego. Having established that, Ralegh's seizure of Guiana is on an ontological level his taking possession of Ezrabeta Cassipuna Aquerewana. The land is metonymically substituted for the queen and Ralegh is the one who will eventually enter, conquer and possess it, treading where no Christian prince has ever tread. ${ }^{69}$ However, not only does the pristine land represent the queen, Ralegh becomes the one who will succeed where Prince Philip of Spain, Prince Frederick of Denmark, King Charles of France and the Archduke Charles of Austria have failed. He will be the one to conquer the queen's body. Consequently, Ralegh substitutes the protocolonialist discourse of discovery, which expresses the subjugation of the New World so often in terms of the masculine discoverer penetrating a land gendered as feminine ${ }^{70}$, for the Petrarchan discourse of the courtier's desire for a sexualized virgin queen.

\section{Conclusion}

To conclude, Walter Ralegh's travelogue The Discoverie of Guiana may be read as his effort to come to terms with his failure on at least two levels. First of all on a surface level the voyage itself proved a failure on all accounts. He did not succeed in finding the legendary city of Manoa with its golden potentate El Dorado and, consequently, did not succeed in bringing home any amount of precious metal worth mentioning. His strategy to turn this obvious defeat into victory is to "prove" that Manoa exists without any doubt and that gold is to be had in abundance by relying on those witnesses whose authorities may hardly be questioned, i.e. the Spanish and the indigenous people. However, the twists and turns in his narrative and the absurd concatenations of events described deconstruct his intended purpose and emphasize more the fact that he treads on thin ice and that his arguments are rather tenuous.

Most of all however, on a deeper level Ralegh's Guianian enterprise failed in his endeavour to regain the queen's favour. The Discovery, written

69 | Cf. Ralegh (1596), 211.

70 | Cf. Montrose (1993), 178-179. 
at time when it was obvious that the voyage had been counterproductive in achieving this ultimate goal, draws parallels between the queen's virginal, immaculate body and the land per se. Ralegh sexualizes the land as much as the queen in her capacity as a woman is sexualized by her courtiers, of which Petrarchism provides the adequate rhetorics. The English monarch and the South-American country almost fuse into one and by possessing the land Ralegh also possesses the queen or, to be more precise, will possess her, if she grants him further penetration into the land. Needless to say that this strategy failed as well.

\section{References}

Aubrey, John (1949 [1681-1693]): Brief Lives. Oliver Lawson Dick (ed.), Harmondsworth.

Devereux, Walter Bourchier (1853): Lives and Letters of the Devereux, Earls of Essex, 1540-1646, 2 Vols., Vol. I, London.

Frye, Susan (1993): Elizabeth I: The Competition for Representation, Oxford.

Fuller, Mary C. (1993): “Ralegh's Fugitive Gold: Reference and Deferral in The Discovery of Guiana”, in: Greenblatt, Stephen (ed.): New World Encounters, Berkley, 218-240.

Fuller, Thomas D.D. (1662): The History of the Worthies of England, London.

Greenblatt, Stephen J. (1973): Sir Walter Ralegh: The Renaissance Man and his Roles, New Haven.

Lorimer, Joyce (1982): “The location of Ralegh's Guiana gold mine”, in: Terrae Incognitae, 14, 77-95.

Lorimer, Joyce (2006): “Introduction”, in: Ralegh, Walter (2006 [1596]), Sir Walter Ralegh's Discoverie of Guiana, London.

Lorimer, Joyce (2007): Untruth and Consequences: Ralegh's Discoverie of Guiana and the 'Salting' of the Mine, London.

Marotti, Arthur F. (1982): "Love is Not Love”: Elizabethan Sonnet Sequences and the Social Order Author(s)", in: English Literary History, Vol. 49, No. 2, 396-428.

Montrose, Louis (1993): “The Work of Gender in the Discourse of Discovery”, in: Greenblatt, Stephen (ed.): New World Encounters, Berkley, $177-271$. 
Naunton, Robert (1641): Fragmenta Regalia or Observations on the Late Queen Elizabeth, her Times and Favorites.

Nicholls, Mark/Williams, Penry (2011): Sir Walter Raleigh: In Life and Legend, London.

Ralegh, Walter (1951): Poems. Agnes Latham (ed.), London.

Ralegh, Walter (2006 [1596]): Sir Walter Ralegh's Discoverie of Guiana. Joyce Lorimer (ed.), London.

Rice, George P. (ed.) (1951): The Public Speaking of Queen Elizabeth: Selections from her Official Address, New York.

Shakespeare, William (1997): Othello. Ed: E. A. J. Honigmann. Waltonon-Thames.

Spenser, Edmund (1993): Poetry, New York.

Wills, James (1840): Lives of Illustrious and Distinguished Irishmen, Vol. II, Part II, Dublin. 



\section{Glücksschmied und Schiffbruch}

Reflexionen des Scheiterns zwischen Heinrich v. Kleist, Johann Gottfried Herder, Eberhard Werner Happel

und Adam Olearius

Jörg Wesche

\section{Scheitern ZWISchen Archetypik UND hISTORISCHER ANTHROPOLOGIE}

Scheitern ist menschlich. Leicht ist die ciceronianische Erratum-Formel zur anthropologischen Floskel abgewandelt. Sie sagt zwar wenig aus, doch lässt sich auch wenig gegen sie einwenden. Da sie dem Scheitern weder Anfang noch Ende setzt, legt sie es als conditio humana nahe. Tat-

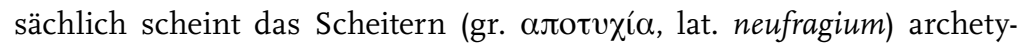
pisch mit dauerhaften Narrativen verbunden. Beginnt man aus literaturgeschichtlicher Perspektive über sie nachzudenken, ist im europäischen Horizont zunächst wie immer die antike Mythologie ein sicherer Fundus. Das mythologische Archiv hält verschiedene Figurationen des Scheiterns, zumal des gescheiterten Hochmuts vor. Zu den nächstliegenden Beispielen zählen die Abstürze hochfliegender Söhne wie Ikaros und Phaeton, die Tantalus-Qualen des Sisyphos oder die mythische Zwickmühle von Skylla und Charibdis, an denen der unerfahrene Seemann Schiffbruch erleidet. Zu den Grundbedingungen dieser Erzählungen gehört neben der Verfehlung einer Zielvorgabe das Moment der Selbstverschuldung sowie der Endgültigkeit (meist des Todes), die im Fall des listigen Wettstreits des Sisyphos mit Thanatos noch über den Tod hinaus andauert und das immerwährende Scheitern als quälende Strafe vor Augen stellt. Natürlich haben solche Erzählungen auch in der Frühen Neuzeit ihr mythenallegorisches Fortleben. Das Emblembuch des Alciatus (1531) etwa 
zeigt als Allegorie menschlicher Vermessenheit (superbia) einen frühneuzeitlich gewandeten Phaeton mit Pferdegespann, der im Ackerwagen die etwas skeptisch dreinblickende Sonne hinter sich herzieht. Jeremias Helds deutsche Übersetzung der subscriptio zum Emblem kommentiert den bevorstehenden Absturz des hochfliegenden Helios-Sohns in der zeitüblichen Manier des Knittelverses:

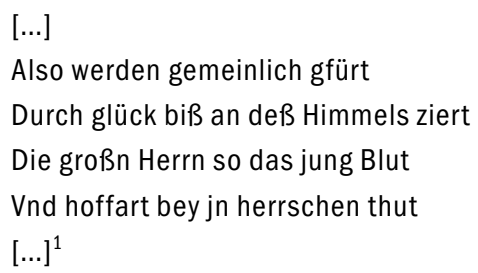

Die moraldidaktische Engführung des heidnischen Mythos als christliche Demuts-Allegorie schärft dabei den Blick für die Frage nach der je spezifischen Geschichtlichkeit von Scheitern, die einer vermeintlich transhistorischen Gültigkeit solcher mythologischen Modelle zuwiderläuft und auf das historisch-anthropologische Erkenntnispotential von Scheitern verweist.

Vor diesem Hintergrund steckt sich die folgende Darstellung ein doppeltes Ziel. In zwei tentativen Annäherungen, die Kleist und Herder ins Zentrum stellen, werden zunächst allgemeine Überlegungen zum Scheitern aus der Perspektive des 18. Jahrhunderts vorausgeschickt, um einige Grundaspekte im diskursgeschichtlichen Feld zu bestimmen und einen historisch kontrastiven Vergleichshorizont zu eröffnen. Die beiden anschließenden Abschnitte sind auf die Barockzeit gerichtet und konzentrieren sich auf das Motiv des Schiffbruchs, da dieses im 17. Jahrhundert das Leitparadigma von Scheitern darstellt. Exemplarisch vertieft wird dies schließlich anhand der Berichterstattung über den Schiffbruch des Husumer Seemanns Volquard Iversen in der Südsee, der von 1655 bis 1668 in Diensten der Vereinigten Ostindien-Kompanie stand. Sein unter der Schirmherrschaft von Adam Olearius herausgegebener Reisebericht hat im 17. Jahrhundert einige Aufmerksamkeit erregt. Die abschließende Analyse legt den Fokus dabei auf einen Vergleich zwischen der autobiographischen Darstellung Iversens in der von Olearius besorgten Fassung

1 | Zitiert nach Henkel/Schöne (1996), Sp. 1615. 
und der späteren journalistischen Berichterstattung in Eberhard Werner Happels Größte Denkwürdigkeiten der Welt oder Sogenannte Relationes Curiosae als bedeutendem Zeitschriftenprojekt um 1700.

\section{DAS geschmiedete Glück des Lebens. ANNÄHERUNG ÜBER KLEIST}

Wer gut plant, scheitert nicht. Daraus spricht ein Selbstvertrauen auf menschliches Kalkül, das gerade im 18. Jahrhundert nicht selten anzutreffen ist. Für die deutsche Literaturgeschichte gibt ausgerechnet der junge Heinrich v. Kleist ein Musterbeispiel, indem er munter eine Anleitung zum Glücklichsein erdenkt, die ein Scheitern methodisch verhindern will. Seinerzeit noch beflügelt von aufklärerischem Tugendenthusiasmus widmet Kleist seinem Regimentskameraden Otto August Rühle von Lilienstern, der ihm später das gemeinsam mit Adam Heinrich Müller herausgegebene Kunstjournal Phöbus mitfinanziert, den Anfang 1799 entstandenen Aufsatz, den sichern Weg des Glücks zu finden und ungestörtauch unter den größten Drangsalen des Lebens - ihn zu genießen! ${ }^{2}$ Sich selbst ebenso wie dem misanthropisch gestimmten Rühle verschreibt Kleist darin wortreich ausgegebene Rezepte einer auf Menschenliebe, innere Bildung, Mäßigung und Gleichmut gerichteten Lebensführung im Sinn der Tugendphilosophie des 18. Jahrhunderts. Zur Läuterung von Rühles Menschenhass entwirft Kleist dabei eine gemeinsame Reise, von der er sich »[t]ausend wohltätige Einflüsse « auf den Begleiter erhofft. ${ }^{3}$ Auf diesem Weg soll menschliche Begegnung im Fremden das Humane hervorbringen. Mit der Analogie von Reise und Leben ${ }^{4}$ richtet Kleist das Menschsein auf das Ziel eines diesseitigen Glücks, das in der eigenen Verantwortung liegt. Damit ist der Mensch bei Kleist der unfehlbaren Logik des planbaren Lebenslaufs unterstellt. Die Lebensrealität Kleists indessen ist bekanntlich eine andere. Denn als Resultat bleibt ein Werk, das sämtliche sicheren Wege gerade verlässt und wie kaum eines durch zerrüttende Wi-

2 | Zum Erstdruck kommt es allerdings erst posthum in der von Theophil Zolling besorgten Werkausgabe Sämtliche Werke (1885).

3 | Kleist, Werke und Briefe (2001), 315.

4 | Dazu etwa Schulz (2007), 89. 
dersprüchlichkeiten, Kontingenz- und Krisenerfahrungen geprägt ist. ${ }^{5}$ Anthropologiegeschichtlich einstehen kann der Glücksaufsatz des jungen Dichters gleichwohl für die historische Latenz eines rationalistisch geprägten Lebensmodells, das dem Einzelnen unter den säkularen Vorzeichen des Aufklärungsjahrhunderts die Heilswirkungen von allgemeiner Menschenliebe, Selbstermächtigung und Voraussicht verspricht, den Menschen im Gegenzug aber auch auf Erfolg verpflichtet. Im Entwerfen des eigenen Lebenslaufs als durchgeplanten Weg zum Glück fügt sich Kleist somit dem wirkungsmächtigen Schema einer persönlichen Erfolgsgeschichte, das als bipolares Basisnarrativ allerdings stets das Scheitern als Gegenstück bereithält. Die ausgeprägte Sensibilität Kleists hierfür scheint dabei in der überspannten Sprachemphase als »performativer Selbstwiderspruch « zum Ausdruck gebracht. ${ }^{6}$ Man traut der enthusiastischen Rhetorik dieses Glücksapologeten nicht und wähnt sie vielmehr im Dienst verzweifelter Selbstüberredung. ${ }^{7}$ Kurzgesagt ebnet Kleists sicherer Weg zum Glück letztlich auch dem Scheitern die Bahn. Die angesprochene Finalität erscheint dabei ebenso für den Erfolg wie für das Scheitern ambivalent, indem sie im Doppelsinn sowohl als sinnstiftende Ausrichtung des Lebens auf ein Ziel als auch als Setzung eines Schlusspunkts verstanden werden kann. Der Finalität als Handlungsmotivation von hinten ${ }^{8}$ korrespondiert entsprechend eine Finalität als Endgültigkeit, die im Fall des Scheiterns - anders als bei der Panne, welche einen behebbaren Zwischenzustand bezeichnet - durch Unumkehrbarkeit trifft. Als Vorstellung hat Kleist die Totalität des Lebensglücks im Sinn. Das Streben danach wird buchstäblich als anthropologische Tatsache und zwanghafter Wunsch von der Geburt bis zum Tod gesetzt:

Denn glücklich zu sein, das ist ja der erste aller unsrer Wünsche, der laut und lebendig aus jeder Ader und jeder Nerve unseres Wesens spricht, der uns durch den ganzen Lauf unseres Lebens begleitet, der schon dunkel in dem ersten kindischen

5 | Die Forschung hat als biographischen Scheitelpunkt vor allem die Erkenntniskrise in Kleists Auseinandersetzung mit der Philosophie Kants im Frühjahr 1801 benannt. Vgl. unter den neueren Arbeiten Hansen (2005).

6 | Fleig (2009), 329.

7 | Ähnlich auch die Argumentation bei Dehrmann (2007).

8 I In Anlehnung an das Konzept des mythischen Analogons bei Lugowski (1994), 61-81. 
Gedanken unsrer Seele lag und den wir endlich als Greise mit in die Gruft nehmen werden. ${ }^{9}$

Die Kehrseite ist ein finales Versagen, das auf die Lebensspanne bezogen und selbstverschuldet ist. Man kann diese Form als biographisches Scheitern bezeichnen und konzeptionell von einem partiellen Scheitern, das als Teilaspekt wiederum den Bezug auf eine Ganzheit impliziert, sowie einem projektbezogenen Scheitern differenzieren, das die Relation zum limitierten Einzelfall zum Ausdruck bringt (mitzudenken sind neben der individuellen Bedeutung freilich kollektive und institutionelle Möglichkeiten von Scheitern wie beispielsweise die gescheiterte Partei). Geläufig ist im Sinn der biographischen Variante etwa die Redeweise von der >gescheiterten Existenzく, während für die partielle und projektbezogene Form jeweils eine stärkere Akzentsetzung auf entweder den persönlichen oder sachlichen Charakter des Scheiterns (wer ist gescheitert oder was?) möglich ist (vgl. z.B. >Scott ist am Nordpol gescheitert $<$ im Gegensatz zu >Scotts Nordpolexpedition ist gescheitert<). Ähnlich gibt etwa das Lexikon für Theologie und Kirche an:

Scheitern an einer den Menschen in seinen konkret lebbaren Möglichkeiten überfordernden, schicksalhaften Situation ( $\rightarrow$ Schicksal) wird unterschiedlich einschneidend erfahren: als Scheitern eines Projekts, einer (beruflichen) Lebensperspektive, einer Beziehung, eines Lebensentwurfs oder Selbstkonzepts ( $\rightarrow$ Identität), schließlich als das Scheitern des institutionalisierten Entwurfs einer gesellschaftlichen (auch kirchlichen) Gruppenidentität. ${ }^{10}$

Ist das biographische Modell der erfolgreichen oder gescheiterten Lebensspanne ideengeschichtlich durchaus eng mit der Aufklärungsbewegung, besonders ihrer forcierten Aufforderung zur Mündigkeit verbunden, kennt das 18. Jahrhundert selbstverständlich auch die partielle und projektbezogene Verwendung, wie sie vor allem im stehenden Ausdruck des >Projektemachers< verbreitet ist und historisch diskutiert wird. ${ }^{11}$ Auch

9 | Kleist (2001), 308f. Dazu auch Fleig (2009), 329.

10 | Werbick (2000).

11 | Vgl. hierzu den Beitrag von Stefan Brakensiek in diesem Band. Für eine kulturgeschichtlich übergreifende Sondierung des Feldes Krajewski (2004). Vgl. darin zur Frühen Neuzeit besonders den Beitrag von Thomas Brandstetter über dis- 
Kleist kann als Projektemacher gesehen werden, der - denkt man z.B. an die Pleite seines Phöbus im Dezember 1808 - dabei nicht zuletzt scheitert. Sein früher Plan zum Glück jedoch ist auf die Lebensspanne angelegt. Natürlich wird man vom Standpunkt historischer Rückschau aus nicht sagen können, dass Kleist als Dichter gescheitert sei. Im Maßstab des eigenen Lebensentwurfs jedoch verfehlt das Glücksrezept sein Ziel.

\section{Anerkanntes Scheitern Und Schicksal als Selbstbestimmung. Annäherung Über Herder}

Mit der Abwägung des Einzellebens nach der bilanzierenden Polarität von planbarem Erfolg oder selbstverschuldetem Misserfolg rückt Voraussicht in den Blickpunkt. Im Zeithorizont Kleists lässt Johann Gottfried Herder in einer kleinen Gesprächsfiktion das komplementäre Brüderpaar Prometheus und Epimetheus als Anwälte von Voraussicht und Zurücksicht ${ }^{12}$ gegeneinander antreten. Gemäß seiner mythologischen Herkunft verteidigt Prometheus die Voraussicht; ähnlich wie bei Kleist ist sein Glaube an ihre Überlegenheit ungebrochen:

Vorsicht ist dem Menschen nöthig: sie erspart inm jene ganze Phrygische Kunst , durch Schaden klug zu werden`, die einzige und doch auch seltne Kunst der Thoren $-^{13}$

Epimetheus hingegen verteidigt seine rückblickende Kunst:

Ich glaube, daß eine kluge Vorsicht nur aus einer überlegenen Zurücksicht entspringe, daß man aus vielen erlebten Fällen doch endlich einmal lerne, wie man bei künftig zu erlebenden Fällen handeln möge. ${ }^{14}$

kursive Strategien der Plausibilisierung, die auf die Entkräftung von Vorbehalten gegenüber der Existenz und Funktionstauglichkeit von Dampfmaschinen um 1700 zielen.

12 | So der programmatische Titel des Gesprächs.

13 | Herder (1795), 71.

14 | Herder (1795), 72 (Hervorhebung im Original). 
Als Schlichterin muss am Ende Pallas Athene die Waagschale zwischen den streitenden Brüdern ins Lot bringen, indem sie Prometheus mit der Kürze der menschlichen Lebensspanne die Begrenztheit planender Voraussicht entgegenhält und auf die Tugend verweist, »ein kühnes Unternehmen durch Klugheit zu beschränken, Hoffnungen durch Erfahrung zu beflügeln und anzuordnen. ${ }^{15}$ Dichtungsgeschichtlich nimmt die Größe prometheischer Autonomie im 18. Jahrhundert wohl am nachdrücklichsten in Goethes zwischen 1772-1774 verfasster Prometheus-Hymne Gestalt an, die den Zeus-Verächter als aufrührerische Ikone des Sturm und Drang-Genies vor Augen stellt. Schon bei Herder wird sie jedoch, wie das Beispiel zeigt, im Schiedsspruch Athenes durch epimetheische Erfahrung beschränkt. Das Scheitern weiß nur der zurückschauende Bruder zu nutzen, indem er die von Prometheus als Torheit verschmähte Kunst der aus dem Schaden gezogenen Klugheit beherrscht. Aus systematischer Perspektive führt die Figurenkonstellation bei Herder damit auf die Frage nach den Konsequenzen des Scheiterns, die hier nicht im Sinn einer Kränkung als Folgeerscheinung gegeben wird, welche das Scheitern als unerwünschte Fehlbarkeit und persönliches Versagen bloßstellt, sondern im projektbezogenen Maßstab auf die Anerkennung des Scheiterns als klugem Ratgeber zielt. Insofern steht Epimetheus für eine Logik des Scheiterns ein, welche die Auseinandersetzung mit Fehlschlägen auf das Ziehen von Schlussfolgerungen verpflichtet. Besonders Prometheus als mythische Figuration der Voraussicht hebt zudem unmittelbar das Moment der Selbstbestimmung ins Licht, wie auch Goethe seinen Prometheus die Selbstbeschwörungsformel aufsagen lässt »Hast du nicht alles selbst vollendet,/Heilig glühend Herz?« und in der berühmten Schlussstrophe jedwede göttliche Schicksalsmacht aus dem eigenen wie dem menschlichen Leben verbannt:

Hier sitz' ich, forme Menschen

Nach meinem Bilde,

Ein Geschlecht, das mir gleich sey,

Zu leiden, zu weinen,

$Z u$ genießen und zu freuen sich,

15 | Herder (1795), 75. 
Und dein nicht zu achten, Wie ich! $!^{16}$

Die entsprechende Lebensvorstellung ist sprichwörtlich: Jedermann sei seines Glückes Schmied. ${ }^{17}$ Im Gegensatz zum verbrieften Glück der durchgeplanten Lebensspanne bei Kleist tritt in Herders Vorstellung vom selbstverantworteten Schicksal wie dargestellt allerdings das rückblickende Moment der Erfahrung durch Fehlschläge hinzu. Die Entscheidung über Erfolg oder Scheitern ist vom vermittelnden Standpunkt Athenes dabei an die persönliche Balance zwischen Vor- und Rücksicht gebunden. Erst die Verbindung beider Sichtweisen kann Souveränität über das eigene Schicksal begründen, wobei die »Umstände«, »unter welchen der Erfolg menschlicher Entschlüsse wirklich wird« aus Sicht Athenes noch im »Schooß der Götter« ruhen. ${ }^{18}$

Gibt der mythische Dialog Herders ein wichtiges Beispiel für die Anerkennung von Scheitern im literaturgeschichtlichen Horizont des 18 . Jahrhunderts, ließe sich in einer hier nicht zu leistenden Weiterführung prüfen, inwiefern seinerzeit auch eine Ästhetik oder Poetik des Scheiterns reflektiert wird. Ein Indiz in dieser Richtung liefert Lessing in seinem Fragment gebliebenen (gleichsam selbst gescheiterten ${ }^{19}$ ) Gedicht über die Mehrheit der Welten, welches die Schönheit des scheiternden Luftschiffers im Weltraum sentenzhaft in einer gewandten figura etymologica bedichtet:

$[\ldots]$

Beherzter als Kolumb, tret ich den Luftweg an,

Wo leichter als zur See die Kühnheit scheitern kann.

16 | Text nach Goethe (2007), 235. Zur poetologischen Dimension der Schöpferpose ausführlich z.B. Neymeyr (2003).

17 | Die phraseologische Belegliste im Grimm'schen Wörterbuch enthält für das Deutsche bezeichnenderweise literarische Belege seit dem 18. Jahrhundert (bei Musäus und Goethe; vgl. Jacob \& Wilhelm Grimm, Deutsches Wörterbuch, Bd. 15 (1899), Sp. 1057). Im Lateinischen lässt sich eine vergleichbare Wendung bis Appius Claudius Caesus (307 v. Chr.) zurückverfolgen (vgl. Röhrich, Lexikon der sprichwörtlichen Redensarten, Bd. 2 (1973), 864).

18 | Ebd., 74.

19 | Vgl. zum Fragment als Textfigur des Scheiterns in der Frühen Neuzeit den Beitrag von Jens Martin Gurr in diesem Band. 
Mag doch die Sinnlichkeit des frommen Frevels fluchen! Genug, die scheitern schön, die scheiternd Welten suchen. $[\ldots]^{20}$

\section{Frühneuzeitliches Scheitern als Schiffbruch}

Das Programm einer selbstbestimmt entwerfenden Lebensauffassung, die das Scheitern durch vorausschauende Planung entweder methodisch suspendiert (Kleist) oder es im Sinn erfolgsorientierter Erfahrung als Optimierungsinstrument anerkennt (Herder), scheint nun zur Beschreibung von Scheitern im 17. Jahrhundert in vielen Bereichen ein unhandliches Konzept. Dies liegt vor allem an der konfessionell übergreifend verbreiteten Schicksalssemantik der Frühen Neuzeit, nach der Jedermann der göttlichen Vorsicht (providentia dei) und den Wechselfällen des Glücks (fortuna) ausgeliefert ist. ${ }^{21}$ Im reformatorischen Kontext etwa erlangt die Prädestinationslehre Luthers Bedeutung, nach der - wie besonders der Traktat über den geknechteten Willen (De servo arbitrio, 1525) wirkungsmächtig darlegt - das persönliche Seelenheil durch menschliche Willenskraft unangetastet bleibt und nur durch die Gnade Gottes zuteilwird. Diese christlichen Rahmenbedingungen lassen den Einzelnen weniger scheitern, sondern ermuntern ihn vielmehr zu neustoischer Duldung und bußfertiger Lebensführung. Ein von übergeordneten Schicksalsmächten befreites Konzept erfolgsorientierter Lebensführung, wie es Kleist vorschwebt, will sich daher nicht ohne weiteres in die Zeit fügen. Hierzu passt die Tatsache, dass Scheitern selbst in der Frühen Neuzeit offenbar selten zur Sprache gebracht wird, die Diskursivierung des Feldes somit vergleichsweise schwach ausgeprägt ist. Der Diskurs der Macht hält

20 | Lessing (1970), 187. Vgl. Lessings kritische Auseinandersetzung mit dem gescheiterten Lehrgedicht im elften Brief in Lessing (1972), 294-295. Über den astronomiegeschichtlichen Hintergrund der kopernikanischen Vorstellung von der Mehrheit bewohnter Welten und Lessings Glauben an eine "[i]nterplanetarische Palingenese" nach dem Tode informiert Guthke (2003), 39.

21 | Zur zentralen Stellung des Vorsehungsmodells im frühneuzeitlichen Weltverständnis etwa Hille (2010), 15. Die Möglichkeit, die Kategorie des Scheiterns zur Analyse frühneuzeitlicher Konfessionsgespräche einzusetzen, erprobt der Beitrag von Marcel Nieden in diesem Band. 
das Scheitern nach der Notwendigkeit des Selbsterhaltungsgesetzes von sich, verneint es und münzt es aus Stabilisierungsgründen durch auctoritas gar in Legitimation um. So lässt der englische König das 1666 fahrlässig niedergebrannte London beispielsweise als göttliche Strafe und sogar Schicksalsglück einer tabula rasa erscheinen, auf der Neues entstehen kann. ${ }^{22}$ Auch in der deutschen Dichtung der Frühen Neuzeit sucht man explizite Verhandlungen des Scheiterns weithin vergebens. Biographisches Versagen gestaltet modellhaft vielleicht am deutlichsten das Genre des Schelmenromans. Einschlägig ist z.B. Grimmelshausens CourascheRoman (um 1669), der die Lebensreise der im Titel als »Erzbetrügerin und Landstörtzerin« diffamierten Heldin durch halb Europa nacherzählt und unter die Vorzeichen eines sozialen Abstiegs setzt. Die trotzige Selbstermächtigung der Frauenfigur, die ihre Lebensbeschreibung agonal gegen ihre Darstellung in Grimmelshausens Simplicissimus (1668) anlegt, führt wie in einem Stationendrama gewissermaßen von einem Scheitern zum nächsten. Ihre Versuche, sich dem begrenzten Spielraum weiblicher Handlungsmöglichkeiten unter den Bedingungen des Krieges zu entziehen, indem sie Hosen anzieht, sich einem Kriegstross anschließt und sich in den nachfolgenden Abenteuern durch aktive Lebensführung um Sicherheit und Profit bemüht, schlagen letztlich sämtlich fehl. So kündigt bereits die Titelei des Romans mit den Worten »Wie sie anfangs eine Rittmeisterin/hernach eine Hauptmännin/ferner eine Leutenantin/ bald eine Marcketenterin/Mußquetirerin/und letztlich eine Ziegeunerin abgeben« an, dass sie den Wechselfällen des Glücks hilflos ausgeliefert ist und ihre rettenden Lebenspläne schrittweise versagen. ${ }^{23}$

Zwar mag man aus der Erzählfiktion ein Narrativ des Scheiterns abstrahieren können, doch fällt der Begriff selbst bei Grimmelshausen nicht. Aus schlicht wortgeschichtlicher Perspektive ist für die Frühe Neuzeit ohnehin zu beachten, dass >Scheitern $<$ im Deutschen noch nicht als verblasste Metapher im Gebrauch ist. Zwar ist das schwache Verb >scheitern< als Verkürzung der früheren Wendung >zu Scheitern werden< eine Bildung des 16. Jahrhunderts, doch wird es zuallererst von »Fahrzeugen und Schiffen gesagt, die in Stücke (Scheiter, s. Scheit) brechen. ${ }^{24}$ Wenn

22 | Vgl. hierzu den Beitrag von Christoph Heyl in diesem Band.

23 | Grimmelshausen (2007), 11. Zum Problem der narrativen Bewertung der Figur Streller (2002).

24 | Kluge (1989), 628. 
etwas in Analogie zu diesem Bildfeld >scheitert<, heißt das in der Frühen Neuzeit zunächst einmal, dass es - so wie etwa bei dem genannten Brand von London - zerstört wird. In den meisten Fällen bleibt die Bezeichnung allerdings auf die Schifffahrt bezogen. ${ }^{25}$ Verwendungsnachweise für scheiternde Personen oder Abstrakta sind wiederum eine Sache des 18. Jahrhunderts, besonders der Goethezeit (Schiller lässt z.B. Wallensteins Glück an Stralsund scheitern). ${ }^{26}$ Auch ein Blick in die deutsche Barockpoesie bestätigt den lexikographischen Befund. Die Bildlichkeit des Scheiterns ist in der Dichtung des 17. Jahrhunderts durchweg an den Schiffbruch gebunden. Stellvertretend verdeutlicht dies das Sonett An den Erlauchten Unglückseligen von Andreas Gryphius, das den Schiffbruch als Daseinsallegorie entwirft, welche statt blumiger Weltsicht die leidvolle Ernsthaftigkeit des Lebens ins Bild setzt:

Held/den rauh unglücklich seyn Unglück überwinden lehret;

Der du rauher Donner Macht

Unerschröckt in Noth verlacht/

Blicke diesen Schauplatz an/drauf man nichts denn Unglück höret/

Schau hier scheitert Kiel und Mast/weil sich Sturm auf Stürme mehret/

Der besteinten Scepter Pracht/

Stuhl und Crone bricht und kracht/

Weil der Fall die Eitelkeit mit Blut/Brand und Folter ehret.

Du senckst den Ancker selbst in bittre Teuffen ein/

Bejammre denn mit mir die unerhörte Pein

Der Seelen/die in Ach in Leid und Todt verschmachten.

Man rühme wie man wil/ein Blumen=reiches Feld/

Wer alles überlegt/wird/tieff=gesinnter Held/

Für leichter Rosen Lust die ernsten Disteln achten. ${ }^{27}$

25 | Vgl. die frühneuzeitlichen Belege bei Jacob \& Wilhelm Grimm, Deutsches Wörterbuch, Bd. 14 (1893), Sp. 2483-2484.

26 | Entsprechende Belege bei Schiller, Klinger, Jean Paul, Goethe und Zachariä, ebd. (1893), Sp. 2483.

27 | Gryphius (1963), 119. Der Kommentar bezieht den Sonetttitel auf den Gesellschaftsnamen von Johann Wilhelm von Stubenberg als Adressaten, der in der Fruchtbringenden Gesellschaft als Übersetzer angesehen war (vgl. ebd., 251). 
Charakteristisch sind hierbei vor allem die Verse

Blicke diesen Schauplatz an/drauf man nichts denn Unglück höret/ Schau hier scheitert Kiel und Mast/weil sich Sturm auf Stürme mehret/

in der Übergangsstellung zwischen den Quartetten. Wird das Scheitern darin zweifach durch Anschauungsmotive gerahmt (»Blicke diesen Schauplatz an« und »Schau hier scheitert Kiel und Mast«), sind damit Schiffbruch- und theatrum mundi-Metapher im Sonett auf zeittypische Weise miteinander verbunden. Damit steht der Text durchaus in der metaphorologischen Tradition des >Schiffbruchs mit Zuschauer<, die Hans Blumenberg von der Antike bis in Moderne als Daseinsparadigma nachverfolgt und den theatralischen Standpunkt des sicheren Betrachters dabei als Bedingung legitimer Neugierde beschrieben hat. ${ }^{28}$ Auch das Barocksonett verschiebt die Katastrophe des Scheiterns in die Schauanordnung der Tragödie, die das Einzelschicksal dabei allegorisch ins Allgemeingültige transponiert. Wie bei Gryphius bezeichnet der Schiffbruch in der Poesie des 17. Jahrhunderts entsprechend nicht das besondere oder >un-vorsichtige< Scheitern des Individuums, sondern im übertragenen Sinn das Scheitern des menschlichen Lebens im Tode. Prägnant dichtet etwa Paul Fleming in seiner Alexandriner-Paraphrase des 130. Psalms zur Luther-Übersetzung eigenständig die Verse hinzu: »HERR/HERR/wer wird vor dir in seinem Thun bestehen./Wir müssen allesampt auff eins zu scheittern gehen. ${ }^{29}$

28 | Blumenberg (1979), 44-45.

29 | Fleming (1986), 6. Weiterführend Fromholzer/Wesche (2012). Geradezu als glückliche Ankunft gestaltet den Tod eines Schiffbrüchigen dann Lessings Grabschrift eines Unglücklichen, welcher zuletzt in einem Schiffbruche umkam:

"Hier warfen mich die Wellen an das Land.

Hier grub mich tot, mit frommer Hand,

Ein Fischer in den leichten Sand

Dein Mitleid, Leser, ist bei mir nicht angewandt!

Im Sturme scheitern und ersaufen,

Hieß mir Unglücklichem, mit Sturm in Hafen Iaufen."

(Lessing [1970], 23). 


\section{Ungeschönte Rede, ErbauUngsmotivik UND ÖKONOMISIERUNG DES SCHEITERNS}

Darstellungsvarianten von Volquard IVersens SchiffBruch in der Südsee bel Adam Olearius und Eberhard Werner Happel

Verlässt man schließlich den Bereich der Dichtung, hat das Thema >Scheitern auf Grund der engen Kopplung an das Bildfeld des Schiffbruchs in der Barockzeit eine deutliche Schlagseite zum Reisebericht. ${ }^{30}$ Gerade das Meer - bis ins Mittelalter vor allem als fundamentale Grenzscheide gedacht - wird im Zeitalter der großen Entdeckungen zunehmend nicht mehr als »Trennungsraum «, sondern als »Verbindungsraum « aufgefasst, der die menschliche Wissbegierde fordert und bereist sein will. ${ }^{31}$ Entsprechend steht das Genre in der Frühen Neuzeit allgemein im Aufwind. ${ }^{32}$ Der Schiffbruch des Husumer Seemanns Volquard Iversen in der Südsee ist geeignet, um anhand eines realen Beispiels für das Scheitern im Wortsinn die autobiographische und journalistische Darstellung in Eberhard Werner Happels Wochenschrift Größte Denkwürdigkeiten der Welt oder sogenannte Relationes Curiosae vergleichend in den Blick zu nehmen.

Zur Klärung des historischen Sachverhalts sei die autobiographische Darstellung Iversens als Ausgangspunkt gewählt. Die Veröffentlichung der Memoiren verdankt sich Adam Olearius, der - bekanntlich selbst Verfasser einer der bedeutendsten Reiseberichte der Barockzeit ${ }^{33}$ - mit Interesse auf die Erlebnisse Iversens als Landeskind des Herzogtums Schleswig stößt. In seinen 1669 herausgegebenen Orientalische[n] ReiseBeschreibungen folgen Iversens Erinnerungen dabei den in vieler Hinsicht ähnlichen, jedoch weitaus umfangreicheren Reiseschilderungen seines Landsmanns Jürgen Andersen. Olearius hat die Entstehung der beiden ungelehrten Berichte ${ }^{34}$ auf Schloss Gottorf koordiniert, in allen Stadien begleitet, redigiert und ergänzt. Ist die veröffentlichungsreife Ausfertigung der teils handschriftlich, teils mündlich vermittelten Erlebnisse von An-

30 | Das Misslingen von frühneuzeitlichen Reiseunternehmungen als Ganzes erörtern die Beiträge von Claudia Claridge und Frank Erik Pointner in diesem Band.

31 | Jahn (1993), 351.

32 | Zur gattungsgeschichtlichen Orientierung immer noch instruktiv Brenner (1990).

33 | Vgl. Olearius (1656). Zur Bedeutung grundlegend Starck (1994), Kap. 2.

34 | Zur Charakteristik der ungelehrten Perspektive ebd., 99-105. 
dersen und Iversen daher wesentlich durch ihn verantwortet, reizt Olearius gerade die »individuelle Erlebnisstruktur, der er als Gelehrter und Mitglied der Fruchtbringenden Gesellschaft aus Gründen der praktischen Benutzbarkeit und der ästhetischen Vorgaben weitergehend entzogen hatte. ${ }^{35}$ Entsprechend präsentiert er beide Texte aus Authentizitätsgründen im autobiographischen Modus der Ich-Perspektive. Man erfährt im kürzeren Bericht Iversens, wie der um 1630 geborene Husumer Buchbinder sein Handwerk an den Nagel hängt und ${ }_{1655}$ als Söldner bei der Vereinigten Ostindien-Kompanie anheuert, um die Welt kennenzulernen. Nach seinem fünfjährigen Pflichtdienst auf den Molukken, deren Flora, Fauna und Einwohnerkultur er recht ausführlich beschreibt, tritt er, da er seine neugierige Reiselust gestillt glaubt, am 23. Dezember 1661 von Batavia aus mit einer holländischen Flotte aus sieben Schiffen unter dem Kommando von Admiral Arnout de Flaming von Outshorn die Heimreise an. ${ }^{36}$ Sein Schiff, die >Arnheim<, gerät jedoch in einen heftigen Sturm und geht unter. Ein Teil der Mannschaft rettet sich im mitgeführten Beiboot und schafft es nach zehn Tagen ungewisser Fahrt bis nach Mauritius, wo sie in kleinere Gruppen aufgeteilt mehrere Monate beispielsweise durch die Jagd auf die endemischen Dodos und dank der vorübergehenden holländischen Besiedelung, durch die u.a. Ziegen eingeführt sind, unter günstigen Umständen überleben. ${ }^{37}$ Als schließlich ein englisches Schiff die Insel anläuft, lässt Iversen sich mitnehmen. Über Umwege gelangt er zurück nach Batavia, wo er weitere viereinhalb Jahre im Dienst der Kompanie steht. 1667 nimmt er seinen zweiten Abschied und kehrt 1668 über Amsterdam nach Husum zu seinem Vater zurück, der ihn längst tot geglaubt hatte. ${ }^{38}$

35 | Ebd., 105.

36 | Bestehend aus den Schiffen "Wapen von Holland", "Arnheim", "Printz Wilhelm ", "Printz Royal“, "Marseveen “, "Der Phönix" und "Der gekrönte Löwe«. Zitiert nach dem Originaldruck von Olearius (1669), 188. Im Folgenden abgekürzt unter der Sigle $0 T$ im Haupttext zitiert.

37 | Das nach Moritz von Oranien benannte Mauritius selbst (s. 'Moritz-Insel) ist zwar seit 1638 niederländische Kolonie, bleibt auf Grund der schwierigen Lebensverhältnisse jedoch nicht durchgehend besiedelt. 1710 wird es von den Niederländern aufgegeben und 1715 von den Franzosen annektiert (vgl. Palmyre [2009], 14-15).

38 | Dort hält es den erfahrenen Ostindienfahrer allerdings nicht lange, da er sein altes Handwerk wegen des Verlusts eines Daumens im Kriegsdienst nicht mehr 
Bemerkenswert ist bei der narrativen Vermittlung der Abenteuergeschichte die Genauigkeit und dramaturgische Anschaulichkeit der chronologischen Darstellung, die Iversens Ostindien-Erfahrungen auf immerhin gut 40 Folio-Seiten in repräsentativer, zum Teil illustrierter Ausstattung entfaltet. Fokussiert man auf die Schilderung des Schiffsuntergangs, sorgt die autobiographische Perspektive eindrucksvoll für glaubhafte Vergegenwärtigung. Iversen erzählt, wie nach mehreren Tagen anhaltenden Sturms die Ladung verrutscht, die Ruderpinne bricht und das Schiff schließlich manövrierunfähig in der See schlingert:

Ob sie zwar sich eusserst bemüheten/eine andere Pinne wieder einzumachen/ kunten sie in dem Sturm doch nicht. Wir hatten die Lucken zwar mit Theertücher gnugsamp verwahret/kunte aber nicht viel helffen. Das Wasser kam unten und oben ins Schiff/und schwummen auff dem Uberlauff die Kisten herumb/und stieffsen etliche Personen zu Boden/nicht ohne sonderliche beschädigung. Die Völker hatten sich die gantze Nacht biß folgenden Mittag mit pumpen und außgiessen gantz abgemattet/kunten auch nicht zu speisen kommen. Es wurden am Bort große Löcher gehauen/daß das Wasser ablauffen kunte. (OT, 189)

Die Passage zeigt die anschauliche, auf Kürze und Schnelligkeit angelegte Erzählweise, in welcher der bevorstehende Schiffsuntergang vermittelt wird. Im Wechselspiel von erlebender Ich- und einschließender Wir-Perspektive entsteht dabei ein in situ-Effekt, der den Leser zum gespannten Betrachter des verzweifelten Überlebenskampfs macht und somit wiederum als Blumenbergs Daseinskonstellation des Schiffbruchs mit Zuschauers beschreibbar ist. Entsprechend lenkt die situative Repräsentation immer wieder auch auf die allegorische Bedeutungsdimension des Geschehens, in dem der gleichsam miterlebende Leser die Erfahrung der rettend eingreifenden Hand Gottes in auswegloser Situation machen kann. So berichtet Iversen, wie die eingeleiteten Hilfsmaßnahmen sämtlich versagen, die Mannschaft ihren Kampf gegen die Schicksalsmacht des Meeres aufgibt $^{39}$ und sich der Naturgewalt sodann erschöpft ausliefert:

ausüben kann. Noch im gleichen Jahr bricht er wieder nach Batavia auf, wo sich seine Spur schließlich verliert. Ausführlich informiert Lohmeier (1980).

39 | Für das wechselhafte Schicksal des Seefahrers trifft hier die hergebrachte Vorstellung einer fortuna di mare. Die lauernden Gefahren des launischen Meeres erfordern dabei menschliches Risikokalkül und die Fähigkeit, der Naturgewalt 
Wir warffen viel Reiß und andere Wahren über Bort/umb das Schiff zu leichtern/ aber vergebens/wollten auch die schweren Ancker und etliche Stücken oder Geschütze/so am Steurbort stunden/über Bort werffen, setzen alle unsere Hände an/und bemüheten uns auffs eusserste/solches zu verrichten, aber das schlenckernde Schiff wolte es nicht zulassen/dann der Sturm bliebe einerley: wir hieben auch den grossen Maß[t] über Bort/weil er das Schiff beschwerete/in meynung/ das Schiff solte sich erheben/aber auch vergebens. Der Pfeffer machete auch die Pumpen unklar/daß wir sie nicht mehr gebrauchen kunten/da sahen wir einander an/ließe die Hände und Muth sincken/dann wir kunten uns nichts als den bald folgenden bittern Tod einbilden. (OT, 189)

Gegen das Wechselglück des Meeres (fortuna) bleibt in diesem Moment nur die Anrufung der höheren Gewalt des göttlichen Schicksals (fatum): »Hier hatten wir niemand als Gott über uns/von dem wir Hülffe und Errettung zu gewarten hatten.« (Ebd.) Kurzerhand wird die bußfertige Haltung auch belohnt, und die Mannschaft setzt auf »Gottes Gnade und Hoffnung« hin die mitgeführte »Schute« aus (ebd.). Dank der helfenden Hand Gottes gelingt schließlich die Entfernung vom sinkenden Schiff und die rettende Fahrt nach Mauritius beginnt.

Die detaillierte Schilderung des Schiffbruchs und der anschließende unverhüllte Bericht über die inhumanen Ereignisse im Beiboot, in dem man zur Verbesserung der Überlebenschancen u.a. beschließt, 18 Personen lebendig über Bord zu schicken, und versucht, sich über mehrere Tage durch Urintrinken zu erhalten, zeichnet nicht zuletzt ein ungeschöntes Bild der Lebensumstände solcher Seeleute, von denen in der historischen Rückschau insgesamt nur etwa jeder Dritte im Dienst der Ostindien-Kompanie überlebte. ${ }^{40}$ Iversens offener Bericht mag insofern

durch instrumentelle Vernunft zu begegnen. Dazu umfassend Wolf (2013). Die Studie entfaltet den Topos und seine literaturgeschichtliche Bedeutung für die Vermittlung des Meeres als Experimentierfeld zwischen Technik und Poetik diachron bis hin zu einem "Ethos des Scheiterns", in der Moderne (ebd., 257). Wolf bringt darin u.a. auch die Entstehung des Versicherungswesens mit der Seefahrt in Verbindung und beschreibt eine "Geburt der Versicherung aus der maritimen Gefahr" (ebd., 89).

40 | Vgl. Driessen (1996), 140-141, der zudem angibt, dass auf Grund der schlechten Lebensumstände " 40 Prozent der Matrosen und 60 Prozent der Soldaten der VOC " Ausländer waren (ebd., 148). 
auch ein Beleg für eine unzensierte Auslandsperspektive sein, die Kritiker der VOC im 17. Jahrhundert durchaus suchten. ${ }^{41}$ Im Zentrum steht jedoch die Gestaltung als Rettungserzählung, die auf die göttliche Vorsicht (providentia dei) verweist und der christlichen Erbauung (aedificatio) des Lesers im angeschauten Scheitern dient. Besonders prägnant gebündelt erscheint diese über den Gesamttext ausgespannte moralisatio in dem vermutlich von Olearius beigefügten gnomischen Epigramm An den Leser, das die vor Augen gestellten Reiseerlebnisse von Andersen und Iversen emblematisch in der gelehrten Norm des Alexandriners engführt:

\author{
Der Leser wird nicht viel von einem Pilgram lesen/ \\ Der so weit aus dem Land' und in Gefahr gewesen/ \\ Da Leben und der Todt sich ziehen bey der Hand/ \\ Als es an diesem Paar durch diß Buch wird bekand. \\ Man sihet wie die Hand des Höhesten kann walten/ \\ Die kann/wo niemand kann/in höchster Noth erhalten. \\ Diß/daß mans glauben soll/hat Gott darumb gethan: \\ Wo Menschen Hülff erstirbt/fängt Gottes Hülff erst an. (OT, 223)
}

Der in der Bearbeitung von Olearius hervorstechenden Ausrichtung der autobiographischen Erzählung Iversens als Erbauungsbuch sei nun abschließend ein vergleichender Ausblick auf die journalistische Verwendung der Rettungsgeschichte bei Eberhard Werner Happel (1647-1690) zur Seite gestellt.

Auch Happel scheint schlicht biographisch von den Möglichkeiten des frühneuzeitlichen Fernreisens fasziniert. Als studierter Mediziner und Jurist der Universität Marburg bricht er nach einer Anstellung als Hauslehrer im Jahr 1668 nach Norddeutschland auf, um ähnlich wie Andersen und Iversen in der Handelsschifffahrt anzuheuern. Nachdem sämtliche Versuche in dieser Richtung jedoch misslingen, lässt er sich in Hamburg

41 | So schreibt Driessen z.B. über eine 1670 in Amsterdam erschienene Sammlung deutscher Reiseberichte: 'J. H. Glazemaker übersetzte Berichte deutscher Compagnie-Diener, da diese vieles beschrieben, wovon die anderen keine Meldung machen (ebd., 35, Hervorhebung im Original zur Markierung des Glazemaker-Zitats). Dass auch der kurz zuvor erschienene Bericht Iversens Eingang in die Sammlung gefunden hat, ist wahrscheinlich, konnte jedoch nicht nachgeprüft werden, da der Originaldruck nicht zugänglich war. 
nieder, verlegt sich auf das Schreiben und etabliert sich schließlich als einer der meistgelesenen Unterhaltungsschriftsteller des 17. Jahrhunderts. Seiner in die Ferne schweifenden Imaginationskraft entspringen mehrere Romane, ${ }^{42}$ die als literarische Welterschließung und geographische Unterweisung für die Jugend dienen sollen. ${ }^{43}$ Hinzu kommt jenes Zeitungsprojekt der Relationes Cursiosae, das unter Happels Ägide als eines der ersten deutschsprachigen Periodika von 1681-1691 in Hamburg erscheint. ${ }^{44}$ Im Format einer Wochenschrift bringt Happel darin Berichte über Denkwürdigkeiten jedweder Art heraus, deren thematisches Spektrum sich von neuesten Erfindungen, über Wunder, Gespenstererscheinungen, Katastrophen, exotischen Tieren oder Völkern bis zu ungewöhnlichen Orten wie Bergen oder Höhlen und eben auch Reisen in entlegene Regionen erstreckt. So entsteht über Jahre ein Raritäten-Kabinett von Klatsch-Relationen, welche unverhohlen die Neugier des curiösen Lesers befriedigen. Das Projekt scheitert dabei nicht, sondern ist im Gegenteil überaus erfolgreich. ${ }^{45}$ Die Relationes finden über Jahre hinweg regen $\mathrm{Ab}$ satz, erscheinen sogar gebündelt in einer fünfbändigen monumentalen Buchausgabe und haben im 17. und 18. Jahrhundert auch über Happels Tod hinaus etliche Fortsetzer und Nachahmer. ${ }^{46}$

Mit Blick auf Iversens Reisebericht ist für Happel die kompilatorische Arbeitsweise typisch, nach der er den Wortlaut bei Olearius weitgehend wörtlich übernimmt, gemäß seines Stilempfindens sprachlich glättet und an einigen Stellen auch durch einbettende Kommentare ergänzt. ${ }^{47}$ Hierzu zählt Happels Einführung in den Iversen-Bericht, in der er die Herkunft seiner Quelle verschleiert und angibt, dass ihm die Geschichte Iversens

42 | Hierzu zählen u.a. Der Asiatische Onogambo (1673), Der Europäischen Toroan (1673), Der Insulanische Mandorell (1682), Der Afrikanische Tarnolast (1689) oder Der Teutsche Carl (1690).

43 | Vgl. zur didaktischen Anlage der Romane im Sinn einer literarischen Geographie Stockhorst (2007), 663-666.

44 | Vgl. als Überblick hierzu Hübner (1990). Im Folgenden wird aus Happels Relationes Curiosae direkt im Haupttext unter der Sigle $R C$ zitiert.

45 | Diskurse zum Scheitern englischer Zeitungsprojekte um 1700 untersucht der Beitrag von Birte Bös in diesem Band.

46 | Zur Rezeption sowie zum genregeschichtlichen Hintergrund Fauser (1996).

47 | Textgrundlage ist wahrscheinlich die Erstausgabe von 1669, da erst 1696 eine zweite Auflage der Orientalischen-Reisebeschreibungen in Hamburg erscheint. 
durch die mündliche Erzählung von dessen Bruder vertraut sei. Anschließend schiebt er den Olearius-Text ein und erhält so die drastische Unmittelbarkeit der situativen Erzählweise im Originaltext. Charakteristisch ist dabei, dass Happel den Iversen-Bericht insgesamt auf wenigen Seiten strafft und - dies ist sicher der erforderlichen Kürze im periodisch erscheinenden Wochenblatt geschuldet - die Erzählung alsbald mit dem glücklichen Wiedersehen des Vaters in Husum abschließt, das er publikumswirksam als sentimentale Rührszene präsentiert. Entscheidend für die Straffung des Erzählvorgangs ist dabei letztlich die narrative Fokussierung auf den Schiffbruch. Die übrigen Teile von Iversens Bericht lässt Happel kurzerhand fort. Im Sinn des curiösen Leserbedürfnisses konzentriert sich Happel somit gezielt auf das Spektakulum des Scheiterns und spitzt Iversens Erlebnisse gegenüber der Fassung bei Olearius noch einmal forcierter als Rettungserzählung zu. Herzstück der so arrangierten Erzähllogik ist die Bündelung und Verstärkung der bei Iversen verstreuten Motive göttlicher Voraussicht und christlicher Erbauung. Neben der spruchartigen Einrückung als Kolumnentitel ${ }^{48}$ belegt dies am deutlichsten der Gebrauch des zitierten Schlussepigramms An den Leser, das auch Happel an das Ende des Zeitungsberichts stellt. Allerdings tilgt er die ersten vier Verse und beschränkt den Text dadurch auf die Reflexion der göttlichen Vorsicht:

So sieht man wie die Hand des höchsten kann walten,

Die kann, wo niemand kann, in höchster Not erhalten:

Dies, daß man glauben soll, hat GOTT darum getan:

Wo Menschen Hülf erstirbt, fängt Gottes Hülf erst an. $(R C, 106)$

Diese Stoßrichtung unterstreicht Happel zudem durch einen nachgestellten Kommentar, der die Lehre der als subscriptio präsentierten Verse verdoppelt. Die gesamte Erzählfolge wird dabei in der Perspektive desjenigen abgeschlossen, der die Geschichte vorgeblich aus der mündlichen Wiedergabe von Iversens Bruder rekapituliert. Am Ende überführt Happel die Erzählung mithin in eine gefällige Rahmenkonstruktion:

48 | Vgl. die Zwischenüberschrift "Die hülfreiche Hand des Allmächtigen" (RC, 101). 
Freilich ist dieses ein Exempel, daran wir sehen können die unendliche Barmherzigkeit des allgütigen Gottes und die unbegreifliche Allmacht des Allerhöchsten, welche einen mitten aus den tobenden Wellen reißen und gnugsam erweisen kann, daß inm seine Hand niemalen könne verkürzet werden, denjenigen, der dem Tode schon im Rachen stecket, zu erretten. (Ebd.)

Auch bei Happel zeigt das Beispiel zunächst den spezifisch frühneuzeitlichen Umgang mit dem Scheitern im Wortsinn an. In der Situation des Schiffbruchs schlägt die Zielorientierung menschlichen Handelns unvermittelt in Orientierungslosigkeit um. Im Scheitern ist der Mensch ausgeliefert. Zu seiner Rettung bedarf es der eingreifenden Hand Gottes, so dass sich die Allmacht und Barmherzigkeit des Schöpfers am Probierstein des Scheiterns erweisen und den Menschen erbauen kann.

Als Schlussgedanke lässt sich jedoch auch eine alternative Lesart plausibilisieren. Denn bewertet man die skizzierten Techniken der narrativen Verschärfung bei Happel im Horizont ihrer journalistisch sehr erfolgreichen Verwertung, gerät der moralische Anschein im edlen Gewand protestantischer Erbauungsliteratur leicht zum Feigenblatt eines Profiteurs des Kuriosen, der die Schaulust kapitalisiert. ${ }^{49}$ Der christliche Deckmantel mag dabei auch als Mittel der Selbstlegitimation willkommen sein. Mit der Vermarktung des Kuriosen im Sinn eines Schiffbruchs mit Leser geht bei Happel schließlich eine Ökonomisierung des Scheiterns einher. ${ }^{50}$ Gesetzt ist damit auf ein Interesse am Scheitern, mit dem sich bis heute guter Gewinn machen lässt. Denn mit dem Scheitern anderer kann man herzlich vergnügen, erbauen und verdienen.

49 | Untermauert wird Happels Faszination für den Iversen-Bericht, aber auch sein Geschick, inn wirkungsvoll zu vermarkten, durch seine literarische Einflechtung in die Erzählfiktion des 1687/88 erschienenen Geschichtsromans Der französische Cormantin.

50 | Insofern fügt Happel den Schiffbruch in eine Marktlücke, die zu dieser Zeit in den Niederlanden längst ausgereizt wird. Vgl. besonders den anhaltenden Erfolg des populären Ostindien-Berichts Journalen van de gedenckwaerdige reijsen des berüchtigten VOC-Kapitäns Willem Ysbrandszoon Bontekoe. Driessen (1996), 35 bemerkt zur Verbreitung: "Nur die Bibel wurde in Holland damals öfter verkauft als dieses Buch: 1646 zum ersten Mal verlegt, erschienen bis 1800 über siebzig Ausgaben." 


\section{QUeLLen}

Fleming, Paul (1986): Deutsche Gedichte, hg. v. Volker Meid, Stuttgart.

Goethe, Johann Wolfgang (2007): Sämtliche Gedichte, mit einem Nachwort v. Karl Eibl, Frankfurt a.M.-Leipzig.

Grimm, Jacob \& Wilhelm (1893): Deutsches Wörterbuch, Bd. 14: R - Schiefe, Leipzig.

Grimm, Jacob \& Wilhelm (1899): Deutsches Wörterbuch, Bd. 15: Schiefeln - Seele, Leipzig.

von Grimmelshausen, Hans Jacob Christoffel (2007): Courasche/Springinsfeld/Wunderbarliches Vogelnest I und II/Rathstübel Plutonis, hg. v. Dieter Breuer, Frankfurt a.M.

Gryphius, Andreas (1963): Sonette, hg. v. Marian Szyrocki, Tübingen (Gesamtausgabe der deutschsprachigen Werke I).

Happel, Eberhard Werner (1990): Größte Denkwürdigkeiten der Welt oder Sogenannte Relationes Curiosae, hg. v. Uwe Hübner/Jürgen Westphal, Berlin.

Henkel, Arthur und Schöne, Albrecht (Hg.) (1996): Emblemata. Handbuch zur Sinnbildkunst des XVI. und XVII. Jahrhunderts, Stuttgart-Weimar.

Herder, Johann Gottfried (1795): »Voraussicht und Zurücksicht. Ein Gespräch«, in: Neue deutsche Monatsschrift 1, 71-75 (Digitalisat des Erstdrucks unter www.ub.uni-bielefeld.de/cgibin/neubutton.cgi?pfad=/diglib/aufkl/ neudeutmon/109951\&seite=00000072.TIF; Zugriff am 6.10.2014).

von Kleist, Heinrich (2001): Sämtliche Werke und Briefe, hg. v. Helmut Sembdner, München.

Kluge, Friedrich (1989): Etymologisches Wörterbuch der deutschen Sprache. Unter Mithilfe von Max Bürgisser und Bernd Gregor völlig neu bearbeitet von Elmar Seebold, ${ }^{22}$ Berlin-New York.

Lessing, Gotthold Ephraim (1970): Gedichte - Fabeln - Lustspiele, hg. v. Herbert G. Göpfert, München (Werke I).

Lessing, Gotthold Ephraim (1972): Frühe kritische Schriften, hg. v. Herbert G. Göpfert, München (Werke III).

Olearius, Adam (1656): Vermehrte Newe Beschreibung Der Muscowitischen und Persischen Reyse So durch gelegenheit einer Holsteinischen Gesandtschaft an den Russischen Zaar und König in Persien geschehen, Schleswig.

Olearius, Adam (Hg.) (1669): Orientalische Reise-Beschreibung. Jürgen Andersen aus Schleßwig/Der Anno Christi 1644 außgezogen/und 1650 wie- 
der kommen. Und Volquard Iversen aus Hollstein/So Anno 1655 außgezogen/und 1668 wieder angelanget. Sind beyde respective durch Ost-Indien/ Sina/Tartarien/Persien/Türckeyen/Arabien und Palestinam gezogen. Und haben zu Wasser und Land viel merckliche Dinge gesehen und erfahren [...]/Heraus gegeben Durch Adam Olearium [...] Mit dessen Notis, und etlicher Oerter Erklärungen/Sampt vielen Kupfferstücken, Schleswig (vollständiges Digitalisat abrufbar unter http://books.google.de; Zugriff am 10.10.2014).

Röhrich, Lutz (1973): Lexikon der sprichwörtlichen Redensarten, Bd. 2: Maul bis zwölf, ${ }^{3}$ Freiburg-Basel-Wien.

\section{LITERATUR}

Blumenberg, Hans (1979): Schiffbruch mit Zuschauer. Paradigma einer Daseinsmetapher, Frankfurt a.M.

Brenner, Peter J. (1990): Der Reisebericht in der deutschen Literatur. Ein Forschungsbericht als Vorstudie zu einer Gattungsgeschichte, Tübingen.

Dehrmann, Mark-Georg (2007): »Die problematische Bestimmung des Menschen. Kleists Auseinandersetzung mit einer Denkfigur der Aufklärung, im Aufsatz, den sichern Weg des Glücks zu finden, im Michael Kohlhaas und der Hermannsschlacht«, in: Deutsche Vierteljahrsschrift für Literaturwissenschaft und Geistesgeschichte 2, 193-227.

Driessen, Christoph (1996): Die kritischen Beobachter der Ostindischen Compagnie. Das Unternehmen der »Pfeffersäcke« im Spiegel der niederländischen Presse und Reiseliteratur des 17. Jahrhunderts, Bochum.

Fauser, Markus (1996): »Klatschrelationen im 17. Jahrhundert«, in: SchmidtGlintzer, Helwig (Hg): Fördern und Bewahren. Studien zur europäischen Kulturgeschichte der frühen Neuzeit, Wiesbaden, 255-263.

Fleig, Anne (2009): »Glück«, in: Breuer, Ingo (Hg.): Kleist-Handbuch. Leben - Werk - Wirkung, Stuttgart-Weimar, 329-331.

Fromholzer, Franz/Wesche, Jörg (2012): » Ich bin nicht itzo ich.< Flemings Psalmenübersetzung im Kontext der frühneuzeitlichen Bußpraxis«, in: Arend, Stefanie/Sittig, Claudius (Hg.): Was ein Poete kan! Studien zum Werk von Paul Fleming 1609-1640, Berlin-New York, 141-158.

Guthke, Karl S. (2003): Lessings Horizonte. Grenzen und Grenzenlosigkeit der Toleranz, Göttingen. 
Hansen, Uffe (2005): »Grenzen der Erkenntnis und unmittelbare Schau. Heinrich von Kleists Kant-Krise und Charles de Villers«, in: Deutsche Vierteljahrsschrift für Literaturwissenschaft und Geistesgeschichte 79, 433-471.

Hille, Martin (2010): Providentia Dei, Reich und Kirche. Weltbild und Stimmungsprofil altgläubiger Chronisten 1517-1618, Göttingen.

Hübner, Uwe (1990): »Nachwort«, in: Happel, Eberhard Werner: Größte Denkwürdigkeiten der Welt oder Sogenannte Relationes Curiosae, hg. v. Uwe Hübner und Jürgen Westphal, Berlin, 491-499.

Jahn, Bernhard (1993): Raumkonzepte in der Frühen Neuzeit. Zur Konstruktion von Wirklichkeit in Pilgerberichten, Amerikareisebeschreibungen und Prosaerzählungen, Berlin.

Krajewski, Markus (Hg.) (2004): Projektemacher. Zur Produktion von Wissen in der Vorform des Scheiterns, Berlin.

Lohmeier, Dieter (1980): »Nachwort«, in: Lohmeier, Dieter (Hg.): Orientalische Reise-Beschreibungen. Jürgen Andersen und Volquard Iversen. In der Bearbeitung von Adam Olearius. Nachdruck der Ausgabe Schleswig 1969, Tübingen, $1^{*}-35 *$.

Lugowski, Clemens (1994): Die Form der Individualität im Roman. Studien zur inneren Struktur der frühen deutschen Prosaerzählung, Frankfurt a.M.

Neymeyr, Barbara (2003): »Die Proklamation schöpferischer Autonomie. Poetologische Aspekte in Goethes Prometheus-Hymne vor dem Horizont der mythologischen Tradition«, in: Hildebrand, Olaf (Hg.): Poetologische Lyrik von Klopstock bis Grünbein. Gedichte und Interpretationen, Köln-Weimar-Wien, 28-49.

Palmyre, Danielle (2009): Kreolische Kultur und Religion in Mauritius, Ostfildern.

Schulz, Gerhard (2007): Kleist. Eine Biographie, München.

Starck, Thomas (1994): Exotische Erfahrung und Intersubjektivität. Reiseberichte im 17. und 18. Jahrhundert. Genregeschichtliche Untersuchung zu Adam Olearius - Hans Egede - Georg Forster, Paderborn.

Stockhorst, Stefanie (2007): »Nachwort«, in: Stockhorst, Stefanie (Hg.): Der Insulanische Mandorell (1682), Berlin, 625-670.

Streller, Siegfried (2002): »Ambivalentes Frauenbild in Grimmelshausens Courasche«, in: Simpliciana XXIV, 67-78. 
Werbick, Jürgen (2000): »Scheitern«, in: Kasper, Walter/Baumgartner, Konrad (Hg.): Lexikon für Theologie und Kirche, Bd. 9: San bis Thomas, Freiburg, Sp. 121.

Wolf, Burkhardt (2013): Fortuna di mare. Literatur und Seefahrt, ZürichBerlin. 